


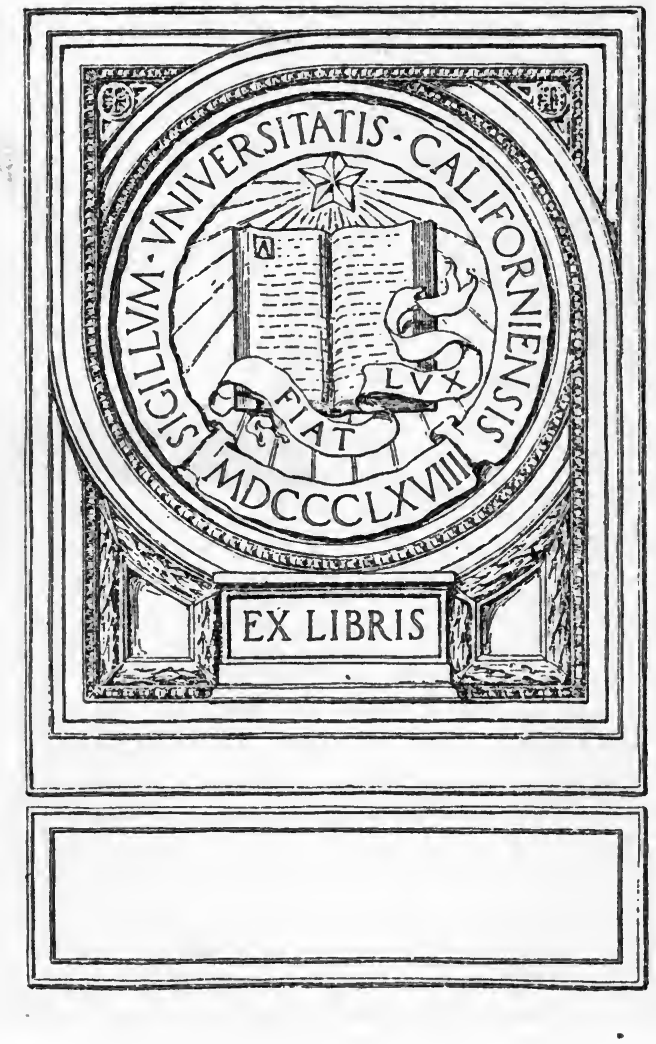


Digitized by the Internet Archive in 2007 with funding from Microsoft Corporation 


\title{
THE BELGIAN CONGO
}

\author{
AND
}

\section{THE BERLIN ACT}




\section{OXFORD UNIVERSITY PRESS \\ LONDON EDINBURGH GLASGOW NEW YORK \\ TORONTO MELBOURNE CAPE TOWN BOMBAY HUMPHREY MILFORD \\ PUBLISHER TO THE UNIVERSITY}




\section{THE BELGIA N CONGO}

AND

\section{THE BERLIN ACT}

BY

ARTHUR BERRIEDALE KEITH

D.C.L., D.LITT.

OF THE INNER TEMPLE, BARRISTER-AT-LAW

REgIUS PROFESSOR OF SANSKRIT AND COMPARATIVE PHILOLOGY AT

THE UNIVERSITY OF EDINBURGH

FORMERLY OF THE COLONIAL OFFICE

AUTHOR OF 'RESPONSIBLE GOVERNMENT IN THE DOMINIONS,' ETC. 
3074

$T T^{52}$
$K 4$ 


\section{PREFACE}

IT is the aim of this work to examine in the crucial instance of the history of the Independent State of the Congo the defects of the Berlin Act, and to indicate the amendments which must be made in that international compact if it is to serve the high purposes for which it was destined, the extension to central Africa of the benefits of civilization and freedom of trade. This limitation of purpose has involved the omission in the historical sketch of the vivid detail of individual heroism and achievement in which the record of the Congo State abounds, but it has also justified the decision not to enter into particulars of the acts of cruelty committed upon natives under the State régime. The exposure of these crimes was a public duty, honourably fulfilled in England, during the period of the agitation to secure the reform of the administration, but since Belgium, under King Albert, has accepted in principle all the reforms. urged by Viscount Grey, it is permissible to refrain from entering. minutely into the investigation of these deplorable events.

In the account of the constitution and administration of the Colony the dislocation produced by the usurpation of authority in Belgium by Germany has been wholly ignored, and the relations between the Congo and the metropolis have been described as they 
exist in law, and as they will revive when the infamy of that occupation has been terminated.

The controversial part of this work rests, of course, on the original authorities, to which I have given full references throughout. In the historical portions I would make special acknowledgement to Dr. Scott Keltie's Partition of Africa and to that storehouse of invaluable information on the Congo, Sir Harry Johnston's George Grenfell and the Congo. Of Belgian writers on the Congo I have selected for citation M. Fritz Masoin's Histoire de l'État indépendant du Congo, for, uncritical as it is, the author's deep devotion to the Roman Catholic Church and his ardent admiration for Leopold II render his statements as to the administration free from all suspicion of bias against the State. The constitutional history of the Congo has had the good fortune to be illumined by the writings of MM. F. Cattier and Charles de Lannoy, and we owe to the care of Dr. Camille Janssen, the first Governor-General of the Congo, and SecretaryGeneral of the Institut colonial international, an admirable selection of the reform legislation of the period 1908-13, inserted in the three volumes of the Recueil international de Législation coloniale.

The recommendations made in Chapter XIX appeared in a summary form in the July number of the Journal of the African Society.

The work has been read in manuscript by my wife, to whom I am much indebted for criticism and other help.

Edinburah, A. BERRIEDALE KEITH.

September, 1918. 


\section{CONTENTS}

\section{INTRODUCTION}

CHAPTER

I. The Early History of the Congo . . 18

II. Leopold II and Stanley $. \quad . \quad-\quad . \quad$. 31

III. INTERnational Rivalry and the Berlin

Conference . . . . . . . 42

IV. The Berlin Act and the Foundation of the Congo State . . . . . 57

V. The Organization of the Congo State and the Brussels Conference . 66

VI. The Conquest of the Katanga . . . $\quad 83$ VII. The Fall of the Slave Traders and the

Military Revolts . . . . . 92

VIII. The Advance to the Nile . . . . 101

IX. The Maladministration of the State a 116

$X$. The Annexation of the Congo to Belgium 137

XI. The British Case against the Congo and the Belgian Reforms . . . 145

1. The British Case against the Congo . 145

2. The Belgian Reforms . . . . 152

XII. The Development of the Katanga and the German Menace. . . . 159

1. The Development of the Katanga . . 159

2. The German Menace . . . 162

XIII. The Reorganization of the Administration 175

1. The Constitutional Division of Powers . 175.

2. The Rights of the Subject . . . 178

3. Administrative Organization . $\quad 183$

XIV. The Judiciary and the Finances . . 191

1. The Judiciary . . . . . . 191

2. The Finances $\quad$. $\quad . \quad$. $\quad . \quad$. 196 
XV. The Land Régine . . . . . 201

1. Native Land Rights . . . . . 201

2. The Domain Lands . . . . 204

3. Registered Lands . . . . $\quad$. 209

XVI. Soctal Progress . . . . . . . 213

1. Social Conditions . . . . . 213

2. Religion . $\quad . \quad$. . . . 217

3. Education . . . . . . 227

4. Public Health . . . . . 230

5. The Protection of the Natives . . 232

XVII. Economic Development . . . . 236

1. Communications . . . . $\quad$. 236

2. Industry $\quad . \quad$. $\quad . \quad$. $\quad . \quad$. 243

3. Commerce . $\quad . \quad$. $\quad$. 250

4. Labour . . . . . . $\quad$. 254

5. The Economic Future of the Congo . 260

XVIII. The Civil and Penal Codes . . . 265

1. Civil Law and Procedure . . . 265

2. Criminal Law and Procedure $\quad$. $\quad 269$

XIX. The Peace Settlement and the Berlin Act 273

\section{APPENDIX}

I. General Act of the Conference of Berlin, signed February 26, 1885

302

II. General ACt of the Brussels Conference, signed July 2, 1890, Chapter VI . .

III. Declaration annexed to the General Act of the Brusseils Conference, sigṇed July 2, 1890 · · • • • •

IV. Convention Respecting Liquors in Africa, signed at Brussels, November 3, $1906 \quad$ • 320

V. Declaration modifying Paragraph 5 of the Declaration annexed to the General Act signed at Brusseis, July 2, 1890, signed at Brussels, June 15, 1910 . . 


\section{INTRODUCTION}

Whatever be the final verdict of history on the part played by the question of colonial expansion among the causes of the European War, two features have emerged in the course of the conflict which render the problem of the future of Central Africa of vital importance to the United Kingdom and its allies. It is true that the submarine has failed to satisfy the high hopes reposed in its efficacy by Germany, but it has achieved remarkable results, and is undeniably a dangerous weapon, greatly diminishing the advantages which else would be derived from British seapower. Happily for the allies, the German fleet during this war has not possessed oversea bases, strong enough to resist attack by sea or land, and equipped to repair and produce submarines to prey on ocean-borne commerce, but it would be idle folly to ignore the grave menace to the liberties of the world, should Germany emerge from the war with the power to create such bases in preparation for a war of revenge, and neglect worse than criminal to fail to consider the provision of whatever measures may be possible to avert this calamity.

The aims of Germany in regard to Africa are notorious: 'Without colonies', Marshal von Hindenburg is reported to have said, 'there can be no industry, and without industry there can be no adequate prosperity. Therefore we must have colonies', and General Ludendorff has given his imprimatur to the views of his titular chief by the declaration that 'Colonies are inseparably connected with Germany's future, for which we must fight and conquer'.' To the German claim for colonial possessions full sympathy was extended in the past by successive British governments, as

${ }^{1}$ Cf. the views of Dr. Solf and Professor Delbrück cited in J.A.S. xvi. 336-8, and A. Bernard's article, ibid. 306-13. 
Prince Lichnowliy has frankly admitted in his record of his dealings with the Secretary of State for Foreign Affairs, and the events of the war have still left not a few ${ }^{2}$ who admit the justice of the claim and regard as necessary the recovery by Germany of the territories which she held before August, 1914. To the colonial party in Germany, . however, such a prospect seems meagre and unsatisfactory, and the demand is made that not only shall the former territories be restored, but that they shall be increased at the expense of France, Portugal, and Belgium so that all Central Africa from sea to sea shall be in the hands of Germany, which then by means of submarine bases on either coast will effectively menace the ocean trade of the allies. $^{3}$

The demand for so large accessions of territory, though justified also on commercial grounds, rests essentially on the second factor which has emerged in the course of the war, the realization of the military potentialities in the training under modern conditions of the natives of Africa. Though France has long made effective use of Senegalese, and though her native troops have rendered admirable service in Europe, the British in Africa have ever made but restricted use of native forces. The causes of this are complex : reminiscences of the Indian Mutiny, confirmed by the unhappy rising in Uganda in 1897, have rendered governments reluctant to raise more troops than were actually necessary for local defence; there have been difficulties in supplying the necessary instructors and in finding officers with the taste and ability to command native Africans, but the chief cause why so little use has been made of African forces in the present war is doubtless that a policy of conciliation and peace seemed to render African armies needless and superfluous. The outbreak of hostilities, therefore,

1 My Mission to London (Cassell \& Co.), pp. 14-19.

2 e.g., the Independent Labour Party's manifesto in The Times, August 29, 1917.

${ }^{3}$ Cf. Dr. Solf"s claims, The Times, August 21, 1918, and Lord R. Cecil's reply, ibid., August 24, General Smuts, ibid., Sept. 13, 1918. 
found the government unprepared to raise or equip native forces, and the course of events has, rightly or wrongly, been deemed not to require any substantial reversal of policy. It is curious, however, that the British policy, which was based purely on political grounds, should have induced a soldier of such skill and experience as General Smuts ${ }^{1}$ to regard as a revelation the possibilities of effective use of native troops manifested by Germany in her able defence of the Cameroons, and in her brilliant operations in East Africa. Large, however, as are the numbers of men whom Germany could raise in the territories possessed by her before the war, the disposition of her Protectorates undoubtedly presented serious points of weakness, and, though submarine bases could be established in them which no naval force available to the United Kingdom and its allies could destroy, these bases would lie open in the long run to reduction by attack from the land. This danger, it is argued in Germany, could bo removed for good if Germany could raise native armies on a sufficient scale to meet on more than equal terms the forces of the allies in Africa, and such pressure might be brought to bear on France as would prevent her employing her native troops in the defence of her European territories. The reasoning cannot be questioned, and it can hardly be gainsaid that it imposes on the allies the obligation of securing that in the peace settlement nothing is done to increase the power of Germany in Africa.

The considerations so far adduced concern only the security of the liberties of the allies, but they serve to show that even the mere restoration of her former territories to Germany will constitute a grave menace, ${ }^{2}$ while the aggrandizement of Germany would be fatal to the hope of an enduring peace. Due consideration must, of course, be given to the possibility of such a change in the spirit of

1 J. A. S. xvi. 281.

${ }^{2}$ Cf. Sir H. Johnston, J. A.S. xvii. 198. The author had in Common Sense and Foreign Policy (1913) favoured the effort then in progress to meet German colonial ambitions. 
Germany as would justify the return of her lost possessions on such conditions as might minimize the danger of evil results, should the change of temper in the German people prove to be but temporary. But in any event the policy of permitting any addition to these lands, which has still support in the United Kingdom, could hardly be regarded as other than suicidal, for the placing in her hands of the potentiality of so much evil would be a temptation to which her new virtue should not be exposed, and it is idle to believe that any conditions could effectively be imposed on the power of utilizing for her own ends the vast resources of Central Africa.

It is, however, impossible for the allies to treat the question as one to be determined by consideration of their own interests, without regard to the needs and aspirations of the native peoples. The German record in her Protectorates has been consistent to a degree which no other power can rival: she has interpreted the harsh and proud Roman maxim,

Parcere subiectis et debellare superbos,

in the narrowest and most ignoble spirit. Her efforts have been devoted to reducing the peoples of the countries over which she has acquired power to a condition of political and economic serfdom, and she has accomplished her end by measures of savage oppression. ${ }^{1} \quad$ It is idle to seek to palliate the misdeeds of Germany by praise of the undoubted economic results which she has achieved by the use of forced labour or by adducing the wrongdoing of the agents of other governments in Africa. If we grant the truth of the doctrine of the Tuskegee school, which sees in work the mode of redemption of the negro, nevertheless, the history

${ }^{1}$ Cf. the official Report on the Natives of South West Africa and their. treatment by Germany, issued September, 1918, an appalling document, and see also J. H. Harris, Germany's Lost Colonial Empire, pp. 17-37; Bishop Frodsham, The Nineteenth Century, October, 1917, pp. 727-38; S. M. Pritchard. J. A. S. xvi. 1 sq. ; H. F. Reeve, United Empire, 1916, pp. 780 sq.; Cd. 8306 ; below, chap. xix. 
of the Southern States of the United States of America proves beyond doubt that the impulse to work must be instigated by other motives than force, and must have as its aim the betterment of the labourer, and not the profit of the taskmaster: the history of the Gold Coast under British Government shows that, with adequate inducement in the form of personal gain, great economic activity may safely be expected from negroes, ${ }^{1}$ and with that activity a steady development of appreciation of the value of membership of the empire and loyalty to its institutions. There can be no more striking contrast in the spirit of the German and British régimes than the scrupulous regard to the religious sentiment of the subject races which has imposed severe restrictions on Christian missionary endeavour in the Mohammedan emirates of Nigeria, and the deliberate adoption of the policy of crushing Mohammedanism in East Africa $^{2}$ on the ground that it fostered a spirit of independence in the native mind. German atrocities again can be matched, though hardly equalled, by atrocities committed by officers of other powers, but they differ from the latter in that in many cases they were no more than the deliberate carrying out of the same policy which devastated Belgium and Northern France, and has let loose massacre and famine in Serbia, on the plea that the end justifies the means : no other modern nation has deliberately adopted as its end the extermination of a people such as the Hereros in SouthWest Africa.

But, though German rule presents a darker side than that of any other great nation of Africa, it may fairly be argued that all nations have sinned in their treatment of African races, and that in any event the problem of introducing civilization in the place of barbarism is one which presents difficulties which are peculiarly hard to overcome. The complications of the question of the native lands in Southern Rhodesia, which have received legal settlement by a recent

1 Cf. W. A. Cadbury, Labour in Portuguese West Africa (1917).

${ }^{2}$ Cf. The Times History of the War, X. 129. It is quite impossible to minimize the meaning of Dr. Schnee's proposals. 
decision of the Judicial Committee of the Privy Council, ${ }^{1}$ illustrate how hard it is to preserve in practical life an even balance between native and European, and admiration for the enthusiasm and ability of the Chartered Company must be tempered by sympathy with natives, dispossessed of much of their best land by causes which they could not control. The interests of the natives, it may fairly be said, demand that the territories conquered in the war should not be restored to an unregenerate Germany, but they do not necessarily preclude their restoration in part at least to a Germany which had repented of its crimes in the war and had overthrown its military régime. But, even in that case, it would be imperative to take such securities as might be proper to provide that the government of the restored possessions should be treated as exercised in trusteeship for the natives. ${ }^{2}$ Unless this be done, the limitless suffering and loss of the war will have been, so far as Africa is concerned, for nothing, and there will be left abundant seed whence new causes of strife will assuredly spring.

But, if these principles are to be applied to Germany, equity and reason demand that they should be applied no less unsparingly to the other powers which hold dominion in Central Africa, and above all to the crucial case of the Belgian Congo which for more than a decade embittered relations between the British Government and the Belgian King, and bred ill-feeling between the peoples of Britain and Belgium. It is true that for a period the French Congo adopted the policy which had embroiled Britain and Belgium, but this aberration ${ }^{3}$ was admittedly derivative in origin, was persevered in for a much shorter period, and finally was disowned by the French Government with sufficient emphasis to satisfy any reasonable critic, and nothing but indifference to foreign achievement can conceal the distinguished ability with which France has managed the affairs of her other African territories. The case of

1 In re Southern Rhodesia, 34 The Times L. R. 595.

2 J. H. Harris, Contemporary Review, February, 1918, pp. 207-12.

3 See C. Humbert, L'Euvre Française aux Colonies, pp. 47-65. 
Portugal presents difficulties of its own : the vast extent of her possessions has always rendered effective administration of the interior out of the question, and, since she dissociated herself from tolerance of the slave trade, her errors on the mainland have been of omission rather than of commission. She has of late undoubtedly made efforts-hardly as successful as could be desired-to eradicate the evils of the system of employment prevailing in San Thomé and Principe, nor can it be doubted that she will readily accept the obligation of any conditions regulating the government of African dependencies which may be decided upon at a European settlement. The only alternative, the acquisition of part of her possessions by foreign powers, is open to grave objection: the partition in the ultimate issue between Germany and the United Kingdom, which formed the subject of the secret agreements revealed by Prince Lichnowsky, has become impossible with the revelation of the German menace, and the British share in that transaction appears from the first to have been dictated merely by the desire to prevent the acquisition of the whole of the territories concerned by an unfriendly power. The future must depend on the fate of Portugal itself, and it is certainly premature to declare that her resources are such as to forbid her ever effectively controlling or developing - with foreign aid-the vast territories which she has acquired in Africa.

It is true that many causes now combine to render difficult an impartial consideration of the position of the Belgian Congo, and the right of the Belgian people to continue to exercise dominion over that possession. The heroic defence of liberty and the public law of Europe by the Belgian people, the gallantry of the King, and the consciousness that to his initiative are due the reforms which have brought healing to the wounds of the Congo State, might seem to render criticism of a régime which has passed away ungracious and untimely. Moreover, two of the chief actors in the movement which produced the reforms in the government of the State have fallen in some measure from their place in the public judgement. It was inevitable that the 
treason of Sir Roger Casement should have tempted the belief that his indictment of the Congo State was distorted by instability of intellect, ${ }^{1}$ and Mr. E. D. Morel's zeal to punish the wrongs of the native of the Congo is perhaps hard to reconcile with the comparative leniency of his judgement of German.actions, not less abhorrent to humanity. ${ }^{2}$ It may be argued, therefore, that the claim of Belgium to enjoy the Congo in full sovereignty and free from restriction should not be called in question or form the object of examination. But this would be a partial and inaccurate view, and to adopt it would be to ignore the circumstances of the origin and development of the State which has subjected it to obligations of a special and important character.

Though in strict law it is true that the Congo as a State of international law does not owe its origin to international action at the Berlin Congress, yet it is equally true that but for that Congress it would never have come into being, that the principles of the Congress were developed with the express purpose of being applied to the new State, and that there was at the time a general belief that the action of the State in its development would be international in character. By a process of interest and importance the international character of the State has disappeared with its transformation into a Belgian possession, but the obligations which the Berlin Act imposed are no less binding than before the transformation and are loyally accepted by the Belgian Government. Yet, as will be shown in detail, it is idle to contend that these principles were not for years in practice violated and disregarded by the ruler of the Congo State, and that an agency, which was to have made for civilization, in many cases intensified the barbarism of the primitive

1 Cf. R. Williams, United Empire, 1917, p. 451.

2 The natural tendency to refuse to believe in accusations of atrocious conduct cannot survive an impartial review of such evidence as that collected by Mr. E. H. Gorges in his report on the treatment by Germany of the natives of South-West Africa, which establishes wholesale massacre, followed by the reduction of the survivors to serfdom. 
peoples which it controlled. It is true that the most perfect Act might have been set at naught by an unprincipled government, but the mere existence of misrule suggests that the instrument itself was defective, and that a peace settlement should be contemporaneous with its revision or with provision for such revision. Nor is this presumption in discord with the facts : the history of the Congo reveals in the Act grave errors of omission, and still graver faults of vagueness, which must be remedied if in the future the government of African dependencies is to be conducted on the only principle. which renders it justifiable, primary regard to the welfare of the native races over whom dominion is exercised. To neglect the lessons to be derived from the history of the Congo State is an unpardonable error which would certainly revenge itself. Moreover, there is another side to that history; amid grave error and crime a record of achievement which vindicates the right of Belgium to claim that the transformation of the Congo territory into a Belgian Colony is morally justifiable, and that Europe should entrust to her, on such new conditions as may be necessary, the control of the vast areas acquired for her by King Leopold.) 


\section{CHAPTER I}

\section{THE EARLY HISTORY OF THE CONGO}

IT is to European travellers and to modern linguistic and ethnographic science that we owe the little knowledge we possess of the state of the Congo prior to the bright light cast upon it by the explorations of Stanley. Evidence of any early occupation of the river valley is not abundant, but it is a plausible conjecture ${ }^{1}$ that the pigmies, who are still found in many parts of the territory, were the earliest inhabitants. They appear to have been in part dispossessed, in part assimilated by two later invasions, in either case by tribes of Bantu speech. At least this theory accounts best for the clear distinction between the language of the lower Congo and south central Congoland and the speech of the tribes to the north, north-east, and east, and it is not impossible that the former tribes represent an offshoot from the Bantu migrations which founded kingdoms in Uganda, Nyasaland, and Zambesia, and, skirting the dense forests of the central Congo, penetrated as far west as the mouth of the river, and even carried their speech to Kabinda and Loango. In the valley of the Upper Nile, which may have been the starting-point of the migration, the negro stock, which is at the base of the population of the Congo, may have been modified by intermixture with Mediterranean man: ${ }^{2}$ in the Congo basin itself it has unquestionably mingled with the pigmy, and.in the Katanga with the Bushman stock of South Africa.

It is idle to seek to assign dates, however approximate, to these tribal movements. There is more evidence for the

${ }^{1}$ Cf. Sir H. Johnston, George Grenfell, ii. 497 sq.

${ }^{2}$ Cf. V. Giuffrida-Ruggeri, Nuovi Studi sull antropologia dell' Africa Orientale (Florence, 1916). 
founding in the course of the fourteenth century of a small kingdom on the southern bank of the Lower Congo, which appears gradually to have acquired some measure of control of the lower course of the river. It was not, however, until the end of the next century that European relations with the Congo began. ${ }^{1}$ In 1471 the river Ogoué had been discovered by an expedition dispatched by the first Portuguese company formed to trade with Africa in slaves and gold dust: in 1482-4. Dom Diogo Cão explored the coast south from the Ogoué and sailed some distance up the mouth of the Congo. From the natives whom he encountered he heard reports of a King of the Congo whose capital city was Mbanza 'Kongo, and on his return to Portugal in 1485 the explorer took with him some natives from the river. Acting, doubtless, with imperfect knowledge of the real importance of the kingdom, Portugal dispatched to the King in 1490 a formal mission under Roderigo de Souza. The expedition was accompanied by Catholic missionaries, whose efforts were successful in converting the King in 1492, and, as usual, the conversion of the ruler brought with it the nominal conversion of large bodies of his subjects./The Christian kingdom flourished: in 1534 a cathedral was built at the capital, which was renamed San Salvador, and in 1549 a Jesuit mission was established there. Some twenty-one years later, howiever, disaster for a time overwhelmed the kingdom : an incursion of a fierce tribe of uncertain provenance, ${ }^{2}$ named Jaggas by the Portuguese, Giagas by the Italians, compelled the King and the Christians to take refuge on an island in the river while the cathedral and churches perished in a conflagration. Help, however, was forthcoming from Portugal: the

1 The original authority for the early period is a Portuguese, Duarte Lopes, who visited the Congo under Philip II of Spain, and whose narrative is reported by F. Pigafetta (1591 : Eng. trans. by M. Hutchinson, 1881). See also J. J. Monteiro, Angola and the River Congo (1875); Johnston, op. cit. i. 69 sq́.

${ }^{2}$ Probably from the Middle Kwango; Johnston, George Grenfell, i. 71, note. 
gallant and ambitious Dom Sebastião sent six hundred men armed with firearms, who speedily drove the Jaggas away, and the city and cathedral were rebuilt. In gratitude for this aid, the Portuguese narrative runs, the King ceded to Portugal the territory from the mouth of the Congo to the Kwanza river; but the version of the Dutch geographer Dapper, converts the cession into a mere offer of an annual tribute of slaves and the acceptance of suzerainty, which Dom Sebastião declined saying, that he regarded the King as his brother in arms, and that he was fully repaid by the constancy he displayed in the Catholic faith. ${ }^{1}$

This episode seems to have marked the highest point of Portuguese influence in the kingdom. Whether acting in virtue of the cession by the King or not, they proceeded in 1574 to the occupation of Angola, and the foundation of the important city of São Paulo de Loanda was begun * in the following year. Their position was soon after seriously affected by the rivalry of the Dutch, when the death of the last King of the House of Avis resulted in the transfer of Portugal to the Spanish crown. It became necessary to concentrate Portuguese effort on the coast, and in 1608 the cathedral of San Salvador was abandoned in favour of that of São Paulo de Loanda. Even on the revival of the Portuguese monarchy the Dutch maintained the feud: São Paulo de Loanda fell into their hands in the period 1640-8, and they sent an embassy in 1642 to the King at San Salvador. The tide, however, turned shortly after, and with reinforcements from Brazil the Portuguese found themselves in a position to retake their capital and to expel the Dutch from the other settlements which they had made on the coast. The development of the traffic in slaves brought prosperity to Angola, as the introduction of a copper coinage in 1694 attests, and the priests who had clung to San Salvador gradually drifted in the last years of the century to the more settled and prosperous Angola.

Missionary effort from other sources was not lacking. 1 Stanley, The Congo, i. 13. 
The Pope, Paul V, dispatched a mission to the King at San Salvador; Urban VIII, in 1640, erected the Congo kingdom into an apostolic prefecture depending directly on Rome, and missions of Capuchin monks proceeded to the Congo in 1644, 1646, 1650, and 1651: the fourth of these missions was accompanied by a Belgian priest, while two Belgians, one of whom met his death at the hands of the natives, were included in the fifth Capuchin mission of 1653. An independent mission of Franciscan Recollets, including a Belgian priest and a Frenchman, arrived between 1673 and 1675 , but stayed only two years. The interest of the Popes in the Congo was unflagging: Innocent $\mathrm{X}$ sent a special mission in 1652 , and not only did the Capuchins labour unceasingly for the propagation of the faith, but they rendered service to knowledge by accounts of the state of the Congo, and study of its language. Father Giacinto Brusciotta, once Apostolic Prefect of the Congo, published at Rome in 1650 and 1659 a vocabulary of the language with renderings in Latin, Portuguese, and Italian, while accounts of the customs of the peoples of the Lower Congo were issued by Fathers Cavazzi, Merolla, and Zucchelli, whose work, however, was largely based on hearsay and decidedly uncritical. But this not unfruitful activity was abruptly terminated by the expulsion of the Capuchins from the kingdom in 1717, and Christianity and civilization, such as they were, appear to have decayed with remarkable rapidity. In 1760, doubtless partly with political aims, the French government obtained the sanction of the Pope for a French Roman Catholic mission, and the Abbé Belgarde, appointed 'prefect of the mission of Loango, Cacongo, and other kingdoms on this side of the Zaire', arrived at the Loango coast in 1766 , but the mission lasted only some eight years, and appears to have accomplished nothing of importance. Italian missionaries in 1778 were more successful; but though they reached San Salvador they did not effect a settlement, and no better luck awaited

i The Portuguese name for the Congo, a corruption of Niari, 'water' ; Stanley, The Congo, i. 2. 
an effort of Franciscans, under the protection of Portugal, to establish a mission at Sonyo on the Lower Congo and to reopen relations with the King of San Salvador in 1781. Their advent was met with suspicion and hostility, and in the following years the missionaries-French, Italian, and Portuguese-seem to bave abandoned the Congo region, though a Portuguese mission seems to have continued its activity on the Loango coast up to the end of the century. Portugal still cherished political designs on the Congo: in 1784 the building of a fort at Kabinda to the north of the river attested a prospect of linking up her possession of Angola with the Congo. But this action aroused the jealousy of France, and the French naval commander, the Marquis de Marigny, drove the Portuguese garrison out of Kabinda in 1785. This step would doubtless have been followed by a French occupation ${ }^{1}$ had not the French revolution deflected the course of history.

The European War which ensued, while weakening France, brought a new factor of importance on the scene. The occupation of the Cape of Good Hope by Great Britain in 1796 had evoked great concern on the part of Portugal, and produced a spasmodic attempt to forestall British progress to the north, which was even at that early period foreseen, by joining the Portuguese territories of Angola and Mozambique. The resources of Portugal, however, were shortly too much engaged in the struggle in Europe to permit of the carrying out of the scheme, and the obligations of Portugal rendered it necessary for her to come to terms with the United Kingdom regarding the slave trade, which she found so profitable, but which had become obnoxious to British sentiment. A treaty of February $19,1810,{ }^{2}$ concluded at Rio Janeiro, bound the Portuguese Government to prohibit slave trading by Portuguese subjects except within the limits of the Portuguese dominions in Africa; and the treaty of Vienna of January 22,

1 An agreement to respect Portuguese claims was patched up for a time by the influence of Spain, on January 30,1786 ; C. 3531 , p. 35.

${ }^{2}$ C. 3531, pl. 1-3. 
1815 , confirmed this obligation, while contemplating action by Portugal at no distant date to extinguish slave trading entirely. The extent of the Portuguese rights of trade were defined in a supplementary agreement of July 28, 1817, by which they were declared to extend on the east coast from Cape Delgado to the Bay of Lorenzo Marques, and on the west from $8^{\circ} \mathrm{S}$. lat. to $18^{\circ} \mathrm{S}$. lat., these being the territories possessed by the Crown of Portugal, and also to the territories of Molembo and Kabinda on the western coast from $5^{\circ} 12^{\prime}$ S. lat. to $8^{\circ} \mathrm{S}$. lat., over which the King of Portugal asserted rights. The abolition of the slave trade by Portugal was delayed; but by a treaty of 1842 co-operation was arranged between the two powers in the suppression of such part of the trade as was not covered by the treaty of 1815 , and in the execution of this treaty a Portuguese tribunal was created in 1844 at Loanda for the adjudication of vessels captured within Portuguese jurisdiction while engaged in illegal trade. The condemnation by this court of a Brazilian vessel captured twenty-five miles north of Ambriz, which was then thought to be on the 8th parallel of S. lat. and to mark the beginning of the Portuguese dominions, elicited from Viscount Palmerston a clear intimation ${ }^{1}$ to the Portuguese Governmènt that the claim of the Portuguese Crown to territorial sovereignty over the territory from $5^{\circ} 12^{\prime}$ S. lat. to $8^{\circ} \mathrm{S}$. lat. was not recognized by the British Crown; and a year later, geographical research having revealed the fact that Ambriz lay eight miles north of the 8th parallel, the British notification was extended to cover the exclusion of that place from Portuguese jurisdiction. ${ }^{2}$ In 18ð3-6 controversy between the two countries ran high. Portugal occupied Ambriz, and contended that the terms of the agreement of 1817 justified her act; she also argued that the occupation of this port would be of value as a means of combating the slave trade, while she asserted that, as the United Kingdom claimed no sovereignty of her own, it was open to Portugal to occupy the territory in the same manner as the United Kingdom had taken possession of the Falk-
1 C. 3531, pp. 10, 11.
${ }^{2}$ C. 3531, pp. 12, 13. 
land Islands. Whatever force there was in the Portuguese contentions, was powerless to outweigh the objections felt by the British Government to the establishment of Portuguese sovereignty, which would carry with it grave restrictions on British trade, and, what was still more repugnant, extend the area in which Portuguese should be able to continue slave trading. A concession was made in the case of Ambriz, ${ }^{1}$ on condition that the boundary of the territory should not be carried beyond the south bank of the Loge, that the interests of British merchants should be secured, and that slavery should be abolished; but at the same time Lord Clarendon warned the Government of His Most Faithful Majesty ' that any attempt of the Portuguese authorities in Africa to extend that occupation will be opposed by Her Majesty's naval forces', and that 'this warning having been given, the responsibility of any consequences which may follow a disregard of it will rest upon the Government of Portugal '. Remonstrances by Portugal, which were renewed in 1860 and 1867, were answered in similar terms, and it was small consolation that in $\mathbf{1 8 5 9}$ opportunity was taken of civil strife in the old kingdom of San Salvador to intervene in favour of a native Prince and to establish him on the throne as Dom Pedro V, ${ }^{2}$ though the occupation of the capital continued until 1866. San Salvador, which had been rediscovered by the German explorer Dr. Bastian in 1857, had sunk from its former legendary grandeur to an insignificant village with the most faint traces of its former Christianity.

Despite the long period of their connexion with the Congo coast, the knowledge of the Congo region acquired by the Portuguese remained rudimentary. Their knowledge of the Congo river extended no farther than Manyanga, nor is there any record of their knowledge of the existence of Stanley Pool, though vague rumours of a ruler, the Great Makoko, of the Anzico in the interior, had pene-

$\therefore$ C. 3531 , pp. 50, 51.

${ }^{2}$ This potentate died in 1891 , and was succeeded by his nephew, Mfutila, who died in 1896, and was succeeded by Dom Henrique. 
trated to them. 'They advanced some distance east of San Salvador, and south-east to the Kwango and Kasai rivers, but the rapids on these streams prevented their progress north to the Upper Congo itself, and, for reasons which are unknown, their influence and civilization seem to have had no attraction for the natives of Stanley Pool or the basin of the Congo. But they endowed the country with food products of high value, the ox, the pig, the muscovy duck, capsicum, ground-nuts, maize, manioc, guava, limes, the orange, the pineapple, sweet potatoes, tomatoes, and the sugar-cane, and provided it with the civilizing influence of tobacco, to rival successfully the intoxicating hemp introduced from the north-east under Mohammedan influence. ${ }^{1}$ They effected also a revolution in the weapons and modes of warfare, but the total result of their Christianizing influence is doubtful, set off as it was by their relentless pursuit of the slave trade. When the Baptist Missionaries reached San Salvador in 1879 they found no other traces of Christianity than a few ruins of the cathedral, a crucifix, and some images of saints which the King used as fetishes, and which were sometimes brought out and carried round the town when there was need of rain.

Great Britain, on the other hand, contributed largely to the knowledge of the geography of the country. From 1783 the British fleet began to cruise off the coast of Lower Guinea, and ten years later Captain Maxwell surveyed the lower course of the stream up to Boma and Noki. The vagueness of the contemporary information as to the river may, however, still be seen in the instructions ${ }^{2}$ which the Admiralty gave to Captain J. K. Tuckey, whom they deputed in 1816 to carry out a complete survey. The expedition met with disaster, the leader and seventeen others perished, but the survey was carried up to 172 miles from the mouth of the river, and ethnographic and linguistic material was acquired. The estuary of the Congo was surveyed by the British vessels Levin and Barracouta of

1 Johnston, George Grenfell, i. 76-8; ii. 600.

${ }^{2}$ Stanley, The Congo, i. 5, 6. 
Captain Owen's expedition : in 1857 the survey was carried up to Matadi, and six years later the traveller, Richard Burton, advanced a few miles farther up stream and described the Yalala falls. Territorial expansion, however, did not enter into the contemplation of the British Government: in 1868 an offer which had been made by France to exchange the Gaboon for the British possession of the Gambia was definitely rejected, ${ }^{1}$ though it is clear that the exchange would have been of high value as a preliminary to any designs on the Congo, and though the rejection of Portuguese pretensions had left the room open to such designs. British influence, however, spread steadily along the coast from the Cameroons to the north bank of the Congo, and a corrupt form of English became the language for trade in that area, meeting Portuguese on the south bank of the river. British activity in suppressing the slave trade made the flag a familiar feature on the coast, and, when the advent of European traders opened up to enterprising natives a profitable employment in piracy, it was by British ships that the evil was met. ${ }^{2}$

To British enterprise also was due the removal of the crass ignorance of the upper course of the Congo which persisted down to the third quarter of the nineteenth century. The earlier expeditions of David Livingstone led him from the Victoria Falls and the Upper Zambezi to the upper course of the Kasai river and to the Kwango, which he explored, reaching the Atlantic coast at Loanda, whence he retraced his steps to the Upper Zambezi and followed its course to the sea. In 1866 he set out on his last journey in the effort to find beyond Lake Nyasa the source of the Nile ; and in the following year he discovered the Chambezi river, which he traced to its source in Lake Bangweolo. In 1868-71 he found that the river issued from Bangweolo under the name of Luapula, and pursued a northerly course to Lake Moero whence it emerged as the Lualaba. The

${ }^{1}$ H. C. Paper 444 of 1870, pp. 8, 9.

${ }^{2}$ By 1875 Admiral Sir William Hewett had suppressed this nuisance; Johnston, George,Grenfell, i. 83. 
farthest spot of the river attained by him was Nyangwe in the Manyema country, at a distance of some fifteen hundred miles from its sources. From Nyangwe he returned to Ujiji, where he met Stanley, dispatched by the New York Herald to effect his relief, but, after proceeding in his company part of the way to Zanzibar, he decided to return to Lake Bangweolo, near which, at Chitambo's, he died in 1873.

Before it was known in Europe that Stanley had succeeded in his mission, two expeditions had been dispatched to aid Livingstone. The first under Lieutenant Grandy was sent by the Congo, but it miscarried, and the leader died near San Salvador in 1873. The other, organized by the Royal Geographical Society, had a more prosperous issue. Under the command of Lieutenant V. L. Cameron it proceeded, undeterred by the news of Livingstone's death, to explore Lake Tanganyika, and advanced thence to the Lualaba at Nyangwe. Cameron, however, recognized that this stream must be the upper course not of the Albertine Nile, as Livingstone believed, but of the Congo, but the difficulties of the task and the inadequacy of his equipment debarred him from verifying his conjecture by following the river to its mouth. He crossed instead the comparatively easy country in the southern basin of the Congo and reached Benguella in November, 1875. Cameron had not confined himself to exploration merely: he had concluded treaties with native chiefs ${ }^{1}$ which gave the United Kingdom the option of assuming a protectorate of the inner basin of the Congo. To this idea the opposition of Manchester and Liverpool to any policy deemed likely to interpose restrictions on trade profits was fatal, even if no other considerations had intervened, but Cameron's journey had raised, in a manner that rendered a decision inevitable, the

1 Cameron went so far as to issue a proclamation taking possession of the Congo basin (dispatch to the Earl of Derby, November 29, 1875), but his action was not supported by Lord Carnarvon, though Sir Robert. Morier had urged a settlement of the Congo question on Lord Beaconsfield ; Fitzmaurice, Lord Granville, ii. 343. 
question of the political future of the country which he had traversed and of the Congo. Portugal had old claims to the territory, which it was anxious to revive; France had begun an advance inland from the Gaboon. The most important trading firm on the Congo was Dutch, and as early as 1875 a German, Captain von Homeyer, had suggested annexation of the Congo by Germany. ${ }^{1}$

On the coast itself from the middle of the century European trade houses had established themselves, ${ }^{2}$ first a French firm in 1855, then in 1869 the Dutch Afrikaansche Handels-Vereeniging, which the English house of Hatton in some measure rivalled. Portuguese agents were numerous, but not rarely disreputable, for it must be remembered that Portugal did not forbid slave-trading by her subjects absolutely until 1878. Little or nothing could be expected from these agencies as contributions to the civilization of the Congo, and trade with the interior was rendered almost impracticable by the exactions of the innumerable tribal authorities through whose territories trade caravans must pass. It might have been expected that some political organization would have arisen spontaneously among the Bantu tribes of the Congo, but the lack of political genius of the Bantu, save when under foreign influence, displayed itself in the anarchy which prevailed. The country was divided up among thousands of petty tribes, constantly at war, and recognizing no more than a formal suzerainty at most of some more important chief. The tribal organization itself existed in all stages of development ; on the lower river some chiefs, like the King of San Salvador, had acquired a considerable measure of power; in others, especially on the Upper Congo, the power of the headiman was almost nominal, and the real power rested with the Council of village elders or the assembly of the free men of the village." The social structure rested upon slavery and polygamy; the freeman engaged in sports or the petty warfare which was ever being

1 Johnston, George Grenfell, i. 83.

${ }^{2}$ Masoin, Histoire de l'État indépendant du Congo, i. 273-7.

3 Johnston, George Grenfell, ii. 700 sq. 
waged between village and village, while the labour of cultivation was performed by his wives or slaves. A primitive fetishism and a lively belief in the power of ghosts led to wholesale human sacrifices of wives and slaves on death, and cannibalism had been developed in the Congo basin to an extent which is probably without parallel in any other part of the world, save perhaps the Pacific Islands. Belief in witchcraft was universal: the power of the wizard or witch to destroy was only equalled by the danger of being accused of witchcraft; trial by the poison ordeal was universal, and progress was manifestly impossible unless and until the elements of civilization could be supplied by some higher race.

Almost at the same moment as the interest of Europe began to be attracted to the Congo, a movement from the east coast was beginning to introduce a higher though native culture, but in conditions which deprived this action of all its value. Though the efforts of the United Kingdom and France, added to the action of the United States, had practically extinguished the sea-borne slave trade on the west coast, there was still a large demand for slaves for Morocco, Tripoli, Egypt, Arabia, and Persia, as well as for Zanzibar itself. ${ }^{1}$ The Arabs who devoted themselves to the trade had originally contented themselves with maintaining their head-quarters at Zanzibar, but about 1865-6 they discovered the Lualaba and the Lomami, and began active slave raiding in the territories watered by these rivers. Livingstone found their operations in full swing when he reached Nyangwe in 1871, and, if unopposed, it was clearly only a matter of time until they became masters of the whole of the Upper Congo down to Stanley Pool. A few of the leaders were of fairly pure Arab blood, but the vast majority of their followers were at most Arabized, and many of them were negroes who enthusiastically supported their masters in their raids. The cruelty and waste of life which these raids involved cannot be overestimated, but there is another side of the picture. The invaders brought with ${ }^{1}$ Cf. Masoin, Histoire, ii. 1-60. 
them a higher civilization, based on Mohammedanism ; they built fine towns to replace the miserable huts which they burned, and they introduced systematic cultivation on a grand scale carried out by the slaves whom they gained by their razzias. ${ }^{1}$ Their rule was despotic and often extremely harsh, but it showed some tincture of Mohammedan legal conceptions, and the regular discipline and firearms of their forces rendered resistance by the scattered tribes whom they attacked out of the question. If the barbarism of the Congo tribes in their native condition demanded European intervention, the advance of the Arab slave traders afforded an even more convincing reason for the interposition of a higher civilization.

1 Masoin, Histoire, ii. 99-107. 


\section{CHAPTER II}

\section{LEOPOLD II AND STANLEY}

IT was at this juncture that King Leopold II of Belgium intervened with results which can hardly have been anticipated even by the most enthusiastic dreams of that farseeing prince. The curiosity of Belgian historians has accumulated abundant evidence of the restless ambition which made the bounds of his small kingdom and the bondage of a constitutional monarchy amid a people jealous of liberty from the first irksome to the King, and drove him to ever new dreams of foreign adventure. ${ }^{1}$. The natural limitations of his position were increased by the neutrality which Europe had, unwisely for herself, and largely at the instance of Prussia, imposed on Belgium, and which precluded the King from any effective participation in the high politics which he loved. The conditions of the day were not favourable for the success of his ambitions: the Belgians were not a colonizing people and remained cold to suggestions of foreign adventure, and the occupation of the most favoured spots for settlement limited severely the possibilities of action. Projects of occupation of territory in Borneo, in Oceania, or in South America could hardly bear fruit, and it is scarcely to be wondered at that his mind should have turned to the conception of securing African territory. Direct annexation, however, he was powerless to effect: he could have expected little or no support for such a proposal in Belgium, and the powers which already had possessions in Africa were certain to regard with disfavour any new-comer, however little they themselves might be inclined to exercise effectively the rights which they claimed or might adduce.

1 Masoin, Histoire, i. 15-19. 
Personal ambition and the desire to aggrandize the kingdom which he ruled must be deemed the motives which actuated the King in his efforts for the exploitation of Africa. His own account, indeed, of his aims was far other: he presented himself throughout his career to the world as one who was animated in all his actions by the most noble and enlightened philanthropy, and for many years the world was content to take him at his own valuation, and to acclaim with one voice 'the generous monarch, who so nobly conceived, ably conducted, and munificently sustained the enterprise which has obtained the recognition of all the great powers of the world, and has ended in the establishment of the Congo State'.' But it is impossible to accept as historical this version of the King's motives, or even to accept as a compromise the theory that motives of philanthropy gradually decayed amid temptation to personal ends. All the actions of the King can be explained without difficulty or improbability on the theory of personal ambition, and such a motive is infinitely more likely to have led to the perversion of his later days than so noble an impulse as philanthropy, however corrupted and misled. Nor in imputing this motive to the King is any slur necessarily cast on his character: ambition and grandiose conceptions can scarcely be deemed other than venial in a monarch, and praise should not be denied his doubtless genuine desire to magnify his country and enrich his people.

It is, however, a very different thing to accept the view that the King acted on personal motives of ambition in his African adventure and to believe, as do his admirers, that from the first he saw the result of his action, and deliberately brought about the end which he attained. Even royal foresight is limited by the imperfections of human intelligence and conditions of time and place, and, when the King took

1 The words of Stanley's dedication to the King of his work on The Congo. Cf. Sir E. Malet's declaration on behalf of the United Kingdom in C. 4361, p. 254. Lord Granville had presentiments of evil (Fitzmaurice, ii. 356), but Sir H. Johnston (Journ. Soc. Comp. Leg. xviii. 30, 31) still believes in the original good faith of the King. 
the decisive steps of summoning to his palace at Brussels on September 12, 1876, a great gathering of explorers and men of science from foreign lands, it can only be held that he realized the possibility that this means would afford him the opportunity of aggrandizement which he had so long sought. In calling this meeting the King acted strictly in his personal capacity, but he was remarkably successful in securing the satisfactory representation of those sections of opinion in the chief countries of Europe which were interested in African exploration. Great Britain had among her representatives Sir Bartle Frere, Mr. (later Sir) William Mackinnon, ${ }^{1}$ and Sir Fowell Buxton; Germany sent with others Dr. Nachtigal and Dr. Schweinfurth; and, besides Belgium, Austria-Hungary, France, Italy, and Russia sent representatives. In each case the representatives had no official mandate; they represented not governments but geographical societies, or were invited on the ground of their eminence in the field of exploration or philanthropy. After three days' session the Conference broke up : its chief outcome was the passing of a resolution in favour of the creation of an International Commission, the African International Association, with its seat at Brussels, with a view to the exploration and civilization of Central Africa, and the establishment of National Committees in each country willing to take part in the work, who would collect subscriptions for the common aim, and select delegates to serve on the International Commission. I

What would have been the outcome of the project, had it ever been carried into effect, must be left to speculation: the glorious vista of international action bringing light and healing to the dark places of Africa was dispelled at once by the negative attitude of the Royal Geographical Society, to which fell the duty of organizing the English National

1 The leading spirit of the East Africa Company, which did much in the following decade to support British interests in East Africa. He continued to interest himself in the King's scheme (Johnston, George Grenfell, i. 408). An interesting account of him is given, on the occasion of his death (June 22, 1893), by Stanley, Autobiography, pp.'446-9. 
Committee. Fear of the unknown and reluctance even to seem to encourage encroachment on territories to which Britain might seem to have a prior claim doubtless explain the decision.' that the National Committee ' while maintaining friendly relations of correspondence with the Belgian and other Committees, should not trammel itself with engagements of an international nature, or with objects other than those connected with geography'. In consequence of this decision no delegates were appointed to the International Commission, and the way was left open for the domination of the Commission by the King himself. Stimulated by his enthusiasm, the Belgian National Committee was formally constituted at a meeting of November 6 , 1876 , and the objects contemplated by it declared to be the suppression of the slave trade and the exploration of Africa. In Germany a National Committee was created which decreed on December 18, 1876, the formation of the German African Society to carry out the same objects as the International Commission, viz. the scientific exploration of the unknown regions of Central Africa; the opening up of Central Africa to civilization and commerce; and, as ulterior object, the extinction of the slave trade. But even in this case the international ideal was departed from, for it was agreed that of the funds raised only a small portion should be remitted to the International Commission, the major part being reserved for German works of exploration and discovery. National Committees were also established by Austria-Hungary, France, Holland, Italy, Portugal, Russia, Spain, and Switzerland, but even the Swiss Committee reserved part of its funds for national work, and France and Italy devoted the subscriptions raised to exploration work in the regions which immediately concerned them, the Gaboon and Abyssinia respectively. The withdrawal of Britain was in some measure repaired by the addition of the United States to the number of countries in which National Committees were created.

1 Recorded in the Proceedings of the Royal Geographical Society for July, 1877 ; reprinted by Stanley, The Congo, i. 33-7. 
I The International Commission held its first and only plenary session at Brussels on June 20 and 21, 1877, when delegates were present from Austria, Belgium, France, Germany, Holland, Spain, Switzerland, and the United States, the absence of Russian and Portuguese representatives being accidental. An executive committee consisting of General H. S. Sanford, ${ }^{1}$ Dr. Nachtigal, and M. de Quatrefages, representing the English-speaking, the Germanic and Latin races, was definitely set up, and measures were concerted for carrying into effect the objects of the Association. An important step was taken in the adoption of a special flag for the expeditions of the Association, a golden star on a blue ground-suggested according to one version. ${ }^{2}$ by the flag used by the King of San Salvador, and definite principles were laid down defining the purposes to be served by a chain of posts, which it was proposed to establish on the route from Zanzibar to the lakes. The personnel of the post were to carry out all kinds of scientific research, astronomical, meteorological, ethnographical, linguistic, and biological, to entertain travellers, and advise them, and by their civilizing influence to suppress the slave trade. The amounts of the contributions announced at this meeting revealed clearly that the work had ceased to be international:! Belgium could report the raising of a total of $287,000 \mathrm{fr}$., and annual subscriptions of 44,000 fr. with further sums to follow, 'and by June, 1879, the Belgian total had exceeded 600,000 fr., against which there were merely small sums from Germany, Austria-Hungary, Switzerland, and Holland. Of the funds expended on the missions dispatched by the Association a large portion was undoubtedly provided by the King, who completely dominated the Association, and succeeded in obtaining the enthusiastic co-operation of General H. S. Sanford, ${ }^{3}$ who appears to have had a truly

${ }^{1}$ In place of Sir Bartle Frere, selected at the original meeting, when British co-operation was still expected (Masoin, Histoire, i. 22).

${ }^{2}$ Johnston, George Grenfell, i. 87 ; for other versions see Masoin, Histoire, i. 25, n. 1 ; ii. 380 . It seems probable that the ${ }_{-}$llag was a European invention.

${ }^{3}$ At one time United States Minister to Belgium; for his views see a c 2 
American enthusiasm for noble sentiments of philanthropy, as well as a keen appreciation of the business possibilities of the opening to trade of the Congo, and who won for the enterprise respectful sympathy in the United States.

Into the detail of the expeditions dispatched by the Association to the east coast of Africa it is as unnecessary as it would be painful to enter. ${ }^{1}$ Entrusted to Belgian officers for the most part, unskilled in the work to be carried out, little or nothing was accomplished at great cost of life and suffering, until the effort, having served its turn, was abandoned in 1885. In two respects, however, historical importance attaches to these expeditions: they served to conceal from the world at large, until they could safely be revealed, the far more ambitious schemes which were in process of being carried out from the west coast under Stanley, and the establishment of the post of Karema, which was abandoned in 1885 and later on handed over to Germany, may have to be borne in mind should at any future time the question be discussed of the division of German East Africa.

Long, however, before the first of these hapless expeditions had left Zanzibar, completely new prospects had been opened out by the famous journey of Stanley, ${ }^{2}$ which established beyond doubt the correctness of Cameron's identification of the Lualaba and the Congo. The great journey of exploration on which the enterprise of the New York Herald and the Daily T'elegraph sent him in 1875, led him in October 1876 to Nyangwe, whence he resolved on the journey which Cameron had been unable to undertake. A journey of 281 days, over 1660 miles of river and 140 miles of land, brought his expedition to the Atlantic, and revealed definitely the great northward bend of the Congo,

letter of his to Sefnator Morgan, elated March 24, 1884, in Stanley, The Congo, i. 36-8. A Sanford Exploring Expedition Company for trade, founded at Brussels on June 28, 1886, proved a failure (Masoin, Histoive, i. 63).

${ }^{1}$ See Masoin, Histoire, i. 222-61.

${ }^{2}$ Described in his Through the Dark Continent, with supplementary matter in his Autobiography. 
which even Cameron had not surmised. From the outset of his adventure Stanley had spared no pains to keep his patrons duly informed of his negotiations and his achievements, and he had not hesitated to insist on the political aspect of the question. He could prove, he claimed in a letter published in the Daily Telegraph of November 12, 1877, that ' the power possessing the Congo, despite the cataracts, would absorb to itself the trade of the whole of the enormous basin behind. This river is and will be the grand highway of commerce to West Central Africa'. Stanley's letters, however, though they produced great missionary activity not merely on the route to Uganda but also on the road to Tanganyika, failed to elicit any response in political circles in England. It is natural and easy to censure ${ }^{2}$ the apathy of the Government of the day, that of Lord Beaconsfield, and doubtless the occasion was a tempting one. But the European world was in the throes of the Eastern question, which might at any time result in war, and, as this menace passed away, the troubles that arose in Afghanistan, in Egypt, and in South Africa, were sufficient to deter any prudent Government from a policy which, as events were to show, would have embroiled it with France, Germany, and Portugal, not to mention Belgium and Holland.

The distraction of the European powers presented too obvious a chance for Leopold to miss, and his eagerness to grasp the opportunity is seen in the haste with which he dispatched his Commissioners to greet Stanley on his arrival at Marseilles on his homeward journey. ${ }^{3}$ Stanley, however, was at that time under the influence of physical exhaustion which had a peculiarly strong effect on his spirits, and it is possible also that in deciding to respond to the royal overtures at that moment he had visions of being able by his personal effort to convince the British people of the

1 The Congo, i, p. vi.

${ }^{2}$ Cf. J. H. Rose, Development of European Nations, 1870-1900, p. 544, with Fitzmaurice, Lord Granville, ii. 341 sq.

3 The Congo, i. 20-8. 
necessity for action. His lectures, however, though they aroused the interest of Gambetta, ${ }^{1}$ remained without political effect: the six months' respite which he had demanded from the King's emissaries in January passed without result; in June the interview desired by the King took place, and in August Stanley, whose health had been restored by a holiday in Switzerland, met the King's representatives at Paris and began those close relations with Leopold which were terminated only by his death, and which unhappily involved his fame in some measure in the popular judgement in the disgrace of his patron.

The result of three months of active correspondence was the summoning to the royal palace at Brussels on November 25, 1878, of representatives of the financial world of England, France, Germany, Belgium, and Holland, who resolved to form themselves into a Comité d'Études du Haut Congo, destined to investigate the commercial possibilities of the Congo basin, the conditions of native trade, the prospects of railway construction, and similar topics. So much enthusiasm was shown at this meeting that a sum of $£ 20,000$ was forthwith promised for immediate needs, and a scheme was elaborated for the establishment of a chain of posts along the river and the acquisition of areas suitable for cultivation in their vicinity. The scheme was further developed at meetings of December 9, 1878, and January 2, 1879, and by January 23 Stanley had left England overland en route to Zanzibar, where he hoped to obtain the services of some of his former servants. Arrangements were made at the same time to send out the Belgian steamer Barga with the necessary material for the ascent of the Congo, and Stanley addressed, on January 7, 1879, an interesting letter $^{2}$ to the Chief Agent of the Afrikaansche HandelsGenootschap, the successor of the Handels-Vereeniging, asking him to collect Kruboys for the expedition.

It is clear that from the first the King had formed projects

${ }^{1}$ The Congo, i, p. vi. Cf. his Autobiography, pp. 334, 537.

${ }^{2}$ Ibid. i. 29-32. 
far other than those of mere commercial expansion or exploration. The new body, indeed, used the flag of the International Association, and Stanley was invited to advise the leaders of the expeditions promoted by that body. The King was Founder and President of the Association and Founder of the Comité, whose President, elected at the first meeting, was Colonel Strauch, who occupied the post of Secretary General of the Association. The composition of the two bodies and the source of their funds were different, though one office was used by both. Those interested in the Comité were representatives of commerce and finance, not explorers; and while England held aloof from the Association two British merchants joined the Comité, and subscribed to it. Nor can it be seriously doubted that the formation of the Committee and its predominantly commercial aspect were merely a cloak for the political aims of the King. The evidence on this head is cumulative and crushing in its total effect. The expedition was shrouded in a veil of secrecy and misrepresentation; it was alleged that its aim was merely to send aid to the Belgian expedition which was to approach the Congo from the west coast. Stanley ${ }^{1}$ himself admitted that the Committee had 'separate and distinct objects in view', and cherished the 'ultimate intention of embarking on a grander enterprise if the reports from the Congo region were favourable'. Still more significant is the decision taken before Stanley had reached the Congo, 'to return every subscription to the merchants of all nationalities who had previously expressed by their various subscriptions their sympathy with the project.'2 If any doubt remains, conclusive evidence is afforded by a communication ${ }^{3}$ which Colonel Strauch addressed to Stanley on his way out, and to which Stanley

1 The Congo, i. 50.

2 The opportunity vas given by the request of the Genootschap for the refund of the contributions made by the Vereeniging, which had gone bankrupt (The Congo, i. 51). The repayment was delayed until 1887, according to Johnston, George Grenfell, i. 451.

3 The Congo, i. 52-4. 
replied from Gibraltar on July 8. Colonel Strauch recommended the acquisition of land from the natives and the establishment of stations occupied by coloured men under the superintendence of white men, as a preliminary to the extension of 'the influence of the stations on the chiefs and tribes dwelling near them, of whom a republican confederation of free negroes might be formed, such confederation to be independent except that the King, to whom its conception and formation was due, reserved the right to appoint the President, who should reside in Europe'. The project, it was added, was not to create a Belgian colony, but to establish a powerful negro state, and the suggestion was made 'that a confederation thus formed might grant concessions (with power to make good what they granted) to societies for the construction of works of public utility, or perhaps might be able to raise loans like Liberia and Sarawak, and construct their own public works'. It was not difficult for Stanley to point out how little the primitive savagery of the Congo native permitted of the accomplishment of the aims desired by his correspondent, but it can hardly be doubted that Colonel Strauch's views represented with precision the ideal then floating before the mind of the King.

Arriving at the mouth of the Congo on August 14, 1879, Stanley proceeded with the men and material which he had collected, and which had been procured for him, to undertake the heroic task of establishing communication between the navigable Congo and Stanley Pool. Vivi, on the north bank of the river, the limit of navigation, was reached on September 26, and a station there was completed by January 24, 1880, leaving Stanley free to proceed with the more difficult part of his task. Then only did the colossal difficulties of the work of constructing a road to the Falls become obvious. To the appalling natural difficulties were added the dangers of a singularly trying climate, and a supply of labour almost ludicrously insufficient for the task to which it was set, while every mile of progress made added to the distance over which supplies 
of material must be conveyed by human labour, that most costly and ineffective of means of transport. ${ }^{1}$ At no time in his career did Stanley's power of character stand him in better stead; but though progress was continuous it was wearisomely slow, and in the meantime events were happening elsewhere which threatened to deprive Stanley and his royal master of the fruits of their labours and diplomacy.

${ }^{1}$ As completed the route consisted of a road from Vivi to Isangila, thence the river to Manyanga, and then the road to Stanley Pool. Stanley's own view favoured a railway line on this route (The Congo, ii. 367 sq.), but the lack of continuity between Isangila and Manyanga was an obvious objection, while the expense prohibited action until the political question was disposed of. 


\section{CHAPTER III}

\section{INTERNATIONAL RIVALRY AND THE BERLIN CONFERENCE}

On November 7, 1880, when Stanley was in the thick of the struggle to establish the route to Stanley Pool, he was surprised to receive near Ndambi Mbongo a visit from a French naval officer, who presented himself as Le Comte Savorgnan de Brazza, Enseigne de Vaisseau. ${ }^{1}$ In the friendly conversations which followed this meeting no hint of rivalry seems to have been breathed by his guest, and Stanley appears not to have entertained any suspicion that his guest was other than the explorer and agent of the French Committee of the International Association he claimed to be. If Stanley's lack of suspicion were real, it must have been a painful surprise to him to find on emerging at the end of his wearisome journey on the north bank of Stanley Pool that he had been anticipated in the selection of the natural site for the terminus of his road. On his arrival on July 27, 1881, at the village Bwabwa Njali, he was met by the Senegalese Sergeant Malamine, the faithful and able servant of de Brazza, who produced a treaty purporting to grant to de Brazza as the representative of France the territory from the Gordon Bennet river, flowing into the Congo about forty yards below the first dangerous rapid, and Impila on the north bank of Stanley Pool. Malamine explained that he was instructed merely to show this document to all Europeans who might approach the Pool. ${ }^{2}$

1 Stanley, The Congo, i. 231-4. Yet Stanley had heard of the French aims by February 6, 1880 (ibid. i. 159).

${ }^{2}$ Stanley, The Congo, i. 292 sq. 
De Brazza had in fact stolen a march on Stanley, and had outwitted the International Association by means which are subject to the same imputation of dubious morality ${ }^{1}$ as the actions of the Association itself. De Brazza, of Italian origin, had entered the French naval service in 1870, and had been employed in the revival of French colonizing enterprise which followed the defeats of 1870-71 in exploration of the once-despised colony of the Gaboon. In company with Dr. Ballay and M. Marche he was engaged from 1875-8 in the exploration of the Ogoue river, which, it was hoped, would prove an effective mode of access to the interior. This belief was proved false by the discovery of cataracts, and de Brazza passed beyond the head-waters of the Ogoue and reached the Alima, flowing eastwards to the Congo. De Brazza, however, had not then heard of Stanley's famous journey, and instead of following, as would else have been the case, the Alima to its junction with that stream, returned, shattered in health, to Europe. There he became aware of the discoveries of his rival, and determined to secure the profits of them for France. To effect this aim, while obtaining the countenance of the French Government, which commissioned him to establish a legal priority of occupation on the navigable Congo at the spot nearest to the Atlantic, he applied for aid to the French Committee of the International Association, and his expedition was financed from that source. Further, to disarm suspicion, it was announced ${ }^{2}$ at a meeting of the Paris Geographical Society that his mission had the eminently laudable but innocuous purpose of exploring the country between the Gaboon and Lake Chad. Though he only left Europe on December 27, 1879, the route which he chose to gain the Congo proved fairly easy for his small party. After founding a station, Franceville on the Ogoue, in June, 1880, he followed the Léfini to the Congo, and there, on September 10,1880, concluded the treaty which Malamine presented to Stanley.

1 Masoin, Histoire, i. 341.

${ }^{2}$ Scott Keltie, Partition of Africa, p. 137. 
The position of Stanley was decidedly difficult: even had he been inclined to ignore the emphatic notification of de Brazza that the territory had been acquired in sovereignty on behalf of France, he would have been unable to obtain the permission of the natives to establish a station either on the spot claimed by de Brazza or in its vicinity, for de Brazza had succeeded by his great charm of personality and energy of character in convincing the natives that it was to their interest to hamper the access of other white men to their territories, and earlier in the year, in February, Messrs. Crudgington and Bentley had been foiled in their efforts to establish a mission station on the Pool by the hostility of the natives at Kinshasa to the south and Mfwa to the north of the Pool alike.1 He determined, therefore, to try his fortune to the south of the Pool, and by a mixture of menace and cajolery secured authority from the chief who claimed control of the land and from Ngalyema, who de facto had occupied the territory, to establish a station near Kintamo, to which the name of Leopoldville was given. ${ }^{2}$ Over four months were spent in the foundation of Leopoldville, and on April 19, 1882, the first expedition for the Upper Congo left the new base. Lake Leopold II was circumnavigated in May, but the expedition terminated with the serious illness of Stanley, who had to return to Vivi, where he found a German explorer, Dr. PeschuelLoesche, who bore a sealed commission from the President of the International Association of the Congo, which had superseded the Comité d'Études, appointing him commander of the expedition in the event of Stanley's disablement. Leaving him in charge, Stanley proceeded with a light heart on July 15 via Loanda to Europe. De Brazza in the meantime had not been idle. After his flying visit to Stanley in November, 1880, he proceeded to the Gaboon, where to his disappointment he found that the help which he had expected was not available. He set himself to

1 Stanley, The Congo, i. 250, 261. Malamine saved them from injury at Mfwa, but secured their departure.

${ }^{2}$ Stanley, The Congo, i. 303 sq. 
remedy this defect, and under his direction the existing stations were reprovisioned and a road made to the Alima, on which a new station was founded, in the hope that a steamer could be transported thither and then launched on the stream. At the beginning of 1882 all was in readiness for his return to the coast, and he proceeded thither exploring en route part of the Niari-Kwilu river, which he hoped to use as a means of access to the Congo by connecting the point, to which it proved navigable from the coast, with Stanley Pool, by a short railway. The hostility of the natives prevented his accomplishing in full degree his aims, and compelled him to proceed direct to the coast, arriving in Europe in June, when he set about to secure the ratification by France of the treaty which he had procured from the Makoko of Mbe. ${ }^{1}$

The body to which Stanley made in October the full report of his transactions was the Comite de l'Association internationale du Congo, which had replaced, as has been seen, the Comité d'Etudes in circumstances of which no more information has been vouchsafed than that the change was made when the International African Association took over responsibility for the actions of the Comite d'Études. ${ }^{2}$ In 'effect, at any rate, the new Association was, as before, the mere instrument of the King of the Belgians, by whose liberality the ever-increasing cost of the expedition was defrayed. Stanley's advice ${ }^{3}$ to the Association was simple : nothing could be secured without obtaining from the chiefs in the Congo basin the cession of whatever rights of government they possessed, and it was essential to construct a railway in substitution for the road, which was clearly a hopeless obstacle tq effective trade. These proposals would require large additions of staff, and involve heavy expenditure, but the Committee were ready for this; and Stanley was pressed to resume control of the expedition and to

1 In addition to the treaty shown to Stanley, de Brazza had secured another ceding territory between the Ogoué, Alima, and Congo (Masoin Histoire, i. 344) ; cf. P. Gaffarel, Notre Expansion coloniale, pp. 211 sq.
${ }^{2}$ The Congo, i. 51, 462.
${ }^{3}$ Ibid. i. $462 \mathrm{sq}$. 
superintend personally the carrying out of the policy which he advised. Stanley consented to return tc the Congo and complete the establishment of the stations as far as Stanley Falls, provided that within a reasonable period an efficient assistant chief were dispatched to administer the establishments on the Lower Congo during his absence on the Upper Congo, so clearly had experience convinced him that it was impossible to leave the principal base of operations in the hands of youthful and inexperienced officers. This condition was accepted by the Committee of the Association, and Stanley left Cadiz on November 23, 1882, reaching Vivi on December 20. He immediately set about expeditions to secure for the Association control over the Niari-Kwilu district south of the Gaboon, which had not yet been declared French territory, in order to provide what was then expected to prove a simpler and more effective route to the Upper Congo. One party, under Captain J. G. Elliott, was dispatched on January 13, 1883, to found a set of stations along the lower course of the Niari, starting from the point on that river nearest to the Congo station of Isangila; while on February 5 Lieutenant Van de Velde was dispatched by sea to ascend the $\mathrm{Kwilu}$ and to acquire territory on either bank. Finally, Captain Hanssens was sent from Manyanga for the upper course of the Niari, with instructions to establish connexion between Manyanga and the river and to join hands with Captain Elliott's expedition. All three missions were successfully carried out by April, and treaties ceding sovereign right acquired on both banks of the river, thus ensuring connexion with the Upper Congo. Stanley himself, after securing treaties with the chiefs of Vivi and its neighbourhood, proceeded to advance to Stanley Falls, which he reached on December 1, finding on the latter stages of his journey melancholy proof of the savagery of the Arab slave-traders, who had followed in his footsteps and had ravaged what was formerly a thickly populated district. After establishing at the Falls a station under the control of a Scottish engineer, he returned to Leopoldville and Vivi, taking steps en route to secure 
treaties of cession of sovereignty from the natives, either directly or by the action of his officers. So successful were his efforts that on April 23, 1884, he was able to report ${ }^{1}$ that from Boma to the Lubamba river on the right bank of the Congo, and thence north to the Niari-Kwilu a solid block of territory had been acquired for the Association, while on the south bank treaties had been made, or were about to be made, covering the whole way from Noki to Stanley Falls. Stanley had accomplished in the fullest measure the mission which he had undertaken, and he was, it is clear, temperamentally unfitted for work too long continued, but his anxiety to return to Europe was restrained by the fact that the Committee had not kept their promise to provide him with an effective successor, who could administer the affairs of the Lower Congo during his absence. Sir Frederick Goldsmid was, indeed, nominated Commissioner-in what relation to Stanley is not altogether clear-by the King in July, 1883, but though he paid a visit to the Congo and restored for a period order in the troubled affairs of Leopoldville, he had returned to Europe by January, 1884, ${ }^{2}$ and the King had chosen-again with no clear indication of his relationship to Stanley-General Gordon to take his place. ${ }^{3}$ To Gordon, as is clear from the letter which he addressed to Stanley on January 6, the interest of the proposed appointment lay merely in the opportunity which it would afford to attack the slave-traders in their haunts, doubtless the Nile basin, and it is not remarkable that Stanley should have demurred to a plan which seemed to him to be equivalent to the abandonment of the fundamental business of the consolidation of the position in the Congo. Gordon, however, was diverted from this project by receiving the opportunity to go to the Sudan under British auspices, and the Committee at last provided Stanley with the substitute whom he needed in

\section{The Congo, ii. 225.}

${ }^{2}$ Ibid. ii. 187. Dr. Peschuel-Loesche had thrown up his commission in November, 1882 ; ibid. i. 469.

${ }^{3}$ Ibid. ii. 226 ; Autobiography, p. 338. 
the person of Colonel Sir Francis de Winton, a man of proved competence. De Winton's arrival in May made it possible for Stanley to leave the Congo on June 10. No one recognized more clearly than he did that the time had come when the position of the Congo could not be determined by treaties with ignorant negroes, but by the arbitrament of the Great Powers in conference.

De Brazza in the meantime had showed much activity, but less happily directed than that of his rival. ${ }^{1}$ The French Parliament on November 21, 1882, approved his treaty with the Makoko, and voted in December 275,000 fr. for an expedition to confirm the result which he had obtained; but unluckily for France's claims de Brazza was slow in proceeding to West Africa, sailing only on March 21,1883 , and when he arrived the activity of Stanley's agents had already secured the territory on the Niari-Kwilu which would have served his purpose of securing an effective route to the Upper Congo. But de Brazza claimed, and the French Government accepted his view, that the treaty-or treaties--which he had obtained gave him a footing on the south bank of the river, a claim which the Association strenuously denied. The question, indeed, permits of no dispute if Stanley's version of the facts is to be accepted, for it would then appear that the cession was merely of a strip of land, of indefinite extension inland, but running some nine miles along the right bank of Stanley Pool. ${ }^{2}$ On the other hand, it appears clear from Stanley's own narrative ${ }^{3}$ that Malamine had much influence on the southern bank, and that there was great conflict of evidence among the natives as to what chief had power over the territory. The evidence, however, on the whole tells in favour of the contention of the Association: the French hold, if any, on the south bank was always weak compared to their unquestioned rights on the north bank, and, while they continued to hold a station on the latter, they early abandoned whatever settlement they might have effected

1 Masoin, Histoire, i. 347 sq.

2 The Congo, i. 293.

${ }^{3}$ Ibid. i. 299. 
on the south bank, though they maintained obstinately their theoretic claim.

Apart, however, from the rival claims of France, which, if made good, would clearly jeopardize the hold of the Association on the river, the legal position of that body was open to grave doubt. It might be true that the Association had concluded treaties with 450 independent chiefs $^{1}$ - or over 400 treaties with more than 2,000 native chiefs ${ }^{2}$ - but it would be absurd to suppose that Stanley of all men believed what he wrote when he said ${ }^{3}$ that the rights of these chiefs ' would be conceded by all to have been indisputable, since they held their lands by undisturbed occupation, by long ages of succession, by real divine right'. It is a minor point that the treaties published ${ }^{4}$ show a distressing confusion between the International African Association and the International Congo Association, but that the terms of these documents were really intelligible to the natives who affixed their marks can scarcely be credible, ${ }^{5}$ and it is still more doubtful-as Stanley's own investigations in the case of de Brazza's cession show-whether the signatories had the right to undertake the obligations which they did. Admitting, however, that Stanley had obtained what was possible in the state of anarchy and barbarism of the country, it still remained to be seen whether the Powers would accept the validity of the claim to sovereign rights by the Association. It was not enough to contend ${ }^{6}$ that the precedents of the English Puritans of the Mayflower in 1620, of the New Hampshire colonists in 1639, of the East India Company, Sarawak, Liberia, and Borneo favoured the right of individuals to accept cessions of territory and found

1 The Congo, ii. 379.

3 Ibid. ii. 379.

5 The case of Pallaballa, where a new treaty of April 19, 1884, was required to explain the first treaty of January 8,1883 , is a clear proof of this ; ibid. ii. 205.

- Cf. the Report of the Committee of Foreign Relations to the 48th Congress of the United States, ibid. ii. 380, 381; Sir Travers Twiss, $A n$ International Protectorate of the Congo River (1883). 
sovereign states. Apart from the technical inaccuracy of part of the argument, it remained true that it was entirely for the Great Powers to decide under what conditions, if any, they would recognize a new sovereignty, and that precedents of recognition were of no substantial importance.

In the meantime Portugal had been engaged in a determined effort to defeat the plans of the International Association by securing from England that recognition of her claims on the Congo which had been withheld during the earlier part of the century. The visit of Cameron had been followed on January 24, 1876, by another appeal to the British Government to reconsider the question, but Lord Derby on February 8 curtly responded with a reminder that the British determination to prevent by force any violation of the status quo still prevailed, ${ }^{1}$ and though a series of shocking crimes committed against slaves by Portuguese subjects, with the aid of a British subject named John Scott, in 1877, strengthened the Portuguese claim ${ }^{2}$ that effective jurisdiction should be established, the British Government maintained its attitude of reserve. The action of de Brazza, however, in special seems to have quickened the fears of Portugal, which in 1881 took steps to render closer its relations with San Salvador, and on November 22, $1882,{ }^{3}$ an earnest appeal was made to the British Government to recognize Portuguese sovereignty in exchange for assurances of commercial freedom and effective action against the slave trade. On December 15, 1882, ${ }^{4}$ Lord Granville was able to intimate that, whilst the British Government declined absolutely to consider the historic claims of Portugal as having any validity, they were prepared to consider favourably an arrangement which would further the freedom of commerce of all nations, and the civilization of Africa by the suppression of the slave trade. The conditions of acceptance of the Portuguese claim were specified as the free navigation of the Congo and the

${ }^{1}$ C. 3531 , pp. 70 sq.

${ }^{3}$ C. 3885, pp. 1-6.

4 lbid., pp. 6, 7; Fitzmaurice, Lord Granville, ii. 344 sq. 
Zambezi and their affluents; the adoption of a low maximum tariff in all the Portuguese African dominions, with the guarantee to Great Britain of most favoured nation treatment; the concession to British subjects in the Congo district of the same rights as were granted to Portuguese subjects as regards purchase or lease of lands, missionary operations, or taxation; the suppression of the slave trade and of slavery; and the precise definition of the extent of the, Portuguese possessions in Africa, together with the transfer to Britain of any Portuguese rights in West Africa between $5^{\circ} \mathrm{W}$. long. and $5^{\circ} \mathrm{E}$. long. Not unnaturally the proposal thus to recognize the position of Portugal caused uneasiness to the International Association, and on March 15, 1883, ${ }^{1}$ Lord Granville made it clear that, in delimiting the internal boundary of the lands over which it was proposed to recognize Portuguese sovereignty, care must be taken to exclude the possibility of extending Portuguese control over Stanley Pool. Generous as were these terms, Portugal with singular fatuity persisted in fighting them item by item, and the final agreement was delayed to February 26, 1884. ${ }^{2}$ The treaty showed at every point concessions to Portuguese obstinacy: the sovereignty of Portugal over the coast from $5^{\circ} 12^{\prime} \mathrm{S}$. lat. to $8^{\circ} \mathrm{S}$. lat. was conceded, the inland limit on the Congo to be Noki, and on the rest of the coast to be the boundaries of the existing possessions of the coast and riparian tribes, the delimitation being entrusted to Portugal, but to be approved by the United Kingdom. All foreigners were to receive equal treatment with Portuguese subjects in all matters in the territory recognized as subject to Portuguese sovereignty; there was to be complete freedom of trade and of navigation on the Congo and its afluents ; complete religious equality was to be established, and the régime of freedom of navigation was to apply to the Zambezi. The customs tariff in the territory was not for ten years to exceed the Mozambique tariff of 1877 , and only to be altered thereafter by agreement. A British and Portuguese Commission was to

${ }^{1}$ C. 3885 , pp. 12-15.

2 C. 3886 .

D 2 
supervise the measures taken to secure free navigation of the Congo, Portugal declining absolutely to permit the establishment of the international control for which Britain pressed. No cession of territory was made by Portugal, but she admitted that her rights on the Shiré did not extend beyond the confluence of the Ruo with that river, gave a right of pre-emption over her West African possessions between $5^{\circ} \mathrm{E}$. long. and $5^{\circ} \mathrm{W}$. long., forbade the raising of the customs tariffs in her African possessions for ten years, and gave British subjects most favoured nation treatment in all these possessions. Portugal also undertook to suppress the slave trade and slavery in her new territory.

The motives of the British Government in arranging this treaty have been much canvassed. Sir H. Johnston, ${ }^{1}$ who praises its terms, censures the British Parliament for failing to ratify it, an accusation which is open to the technical objection that it does not rest with Parliament, save when expressly so provided, to ratify a treaty concluded by the Crown. On the other hand, Dr. Scott Keltie ${ }^{2}$ finds it necessary to defend Lord Granville's action by the assumption that he and Stanley himself acted in the belief that on completing the organization of an administration on the Congo the King of the Belgians would hand over the territory to Britain, which would then have no reason to regret that the mouth of the river was in Portuguese hands. It must be remembered that at this time it was still doubtful whether French claims would not prevail, and that, in any event, as the United Kingdom did not desire itself to take possession, it may have seemed well to settle the matter by allotting power to the one claimant which had some show of historic right. Moreover, the advantages to be gained by the treaty were not negligible, and criticism of its terms is possible only if it could be established that the British might have secured the control for themselves.

1 J. A. S. iii. 459, 460 ; Journ. Soc. Comp. Leg. xviii. 30, 31; Fitzmaurice, Lord Granville, ii. 345, 346.

${ }^{2}$ Partition of Africa, p. 145. This theory is not favoured by what we now know of Lord Granville's views (Fitzmaurice, ii. 355, 356). 
In England itself the treaty was the reverse of popular: it was denounced by the Manchester Chamber of Commerce ${ }^{1}$ on the ground that Portugal would as elsewhere in her possessions hamper British trade, and by the Anti-Slavery Society ${ }^{2}$ on the ground that, whatever her promises, Portugal would never deal effectively with the slave trade. These arguments could be answered, but Lord Granville from the first had dealt with the matter on the basis that Portugal must obtain the assent of the Great Powers to the proposed assertion of her sovereignty, and it was soon obvious that this assent would not be forthcoming. The King of the Belgians recognized in the treaty a grave menace to his plans, and he found ready support both in France and Germany. France still entertained hopes of obtaining the Congo, and on March $13^{3}$ definitely informed Portugal of her refusal to acknowledge her rights. Germany had no immediate prospect of acquiring the Congo, though as early as 1875 annexation had been suggested, and since then Pogge had travelled in the western basis of the Congo and Böhm and Reichardt in the south. ${ }^{4}$ But her merchants had the strongest possible objection to Portuguese sovereignty. Prince Bismarck was only too glad to favour France at the expense of England, and still more to support a project which would place the Congo in the hands of a weak power in lieu of France. On April 17 Prince Bismarck seems to have sounded France as to the desirability of an international discussion of the question, and on the following day he delivered to Portugal and Britain alike a characteristically peremptory refusal to accept the treaty. ${ }^{5}$ On April 22 the Association was further strengthened by the formal accord of recognition of its flag as that of a friendly government by the Government of the United States. ${ }^{6}$ This-the first

${ }^{1}$ C. 4023, pp. $17,30$.

2 Ibid., pp. 40, 44.

${ }^{3}$ Masoin, Histoire, i. 36. The British Government were very imperfectly informed at the time of these proceedings ; see C. 4205 .

4 Johnston, George Grenfell, i. 83.

5 Masoin, loc. cit.

${ }^{6}$ C. 4361, p. 262 ; Stanley, The Congo, ii. 382-3. 
recognition of its territorial sovereignty-was the work of General Sanford, who had taken the deepest interest in the undertaking, and by representing the King as embued with the ideals of the founders of Liberia had won the Senate on April 10 to approve recognition by the executive power. On the following day the King brought to fruition his prolonged dealings with France by the signature of an agreement, under which the Association pledged itself not to cede without previous consultation with France any of the free stations and territories which it had established on the Congo and the Niari-Kwilu, and 'wishing to afford a new proof of its friendly feeling towards France, pledges itself to give her the right of preference, if through any unforeseen circumstances the Association were one day led to realize its possessions'.' It can hardly be doubted that this agreement appeared to France little more than a prelude to the formal transfer of the territory to her control.

The trend of international opinion resulted in a volte-face on the part of Portugal, which decided to see if, since the United Kingdom could not secure the carrying out of the treaty, it were not possible to obtain at least the substance of her aims by recourse to Germany and France. Subsequent events make it clear that the basis of the rapprochement that was then effected between Portugal and the Powers, which had refused to recognize her territorial claims in terms the reverse of complimentary, was their promise, implemented in 1886, to recognize by treaty her preposterous claims to the territory lying between her possessions in Angola and Mozambique, whose union would have shut the United Kingdom out from Central Africa. ${ }^{2}$ Great Britain ${ }^{3}$ made an effort to save the treaty by suggesting wholesale modification especially in the direction of entrusting the

${ }^{1}$ Stanley, The Congo, ii. 388.

${ }^{2}$ Scott Keltie, Partition of Africa, pp. 440-1; Franco-Portuguese treaty of May 12, 1886, Article IV; German-Portuguese treaty of December 30, 1886, Article VII. These claims were for ever settled by the Anglo-Portuguese treaty of June 11, 1891.

${ }^{3}$ C. 4205 , pp. 1 sq. 
control of navigation to an International Commission as originally proposed, but from June on it became clear that only an International Conference could dispose of the issue. The formal proposal was credited to Portugal, ${ }^{1}$ and Germany secured the assent of France to it, by recognizing on September 13, in a note from Prince Bismarck to Baron de Courcel, the validity of the agreement of April 23 giving France the right of pre-emption. ${ }^{2}$ On October $8,{ }^{3}$ therefore, Germany in concert with France issued formal invitations to the leading Powers to take part in an international conference to discuss (1) freedom of commerce in the basin and mouths of the Congo; (2) the application to the Congo and the Niger of the principles adopted by the Congress of Vienna with a view to preserving freedom of navigation on certain international rivers, principles applied later on to the Danube; and (3) a definition of the formalities necessary to be observed so that new occupations on the African coast should be deemed effective. The British Government took no exception in principle to the Conference, though the hostile temper of its promoters was obvious, but insistedfinally with success-on obtaining from Prince Bismarck assurances as to the nature of the topics which were to form the subject of discussion. ${ }^{4}$

In any estimate of the attitude of the British Government during this period, whether as regards the Congo or other African questions, including that of Angra Pequena, then at its height, or as regards New Guinea, on which Germany was about to establish a hold, it is imperative to take into account the actual position of general European politics. It is easy, if this essential consideration is disregarded, as it normally is by critics of Lord Granville's action in Africa and Oceania alike, to represent the period as one of foolish surrenders of territory made without any justification at the expense of the interest of British communities in South Africa and Australasia. Yet nothing can possibly be more unfair or less worthy of a historian than this attitude. The
${ }^{1}$ C. 4205, p. 2.
${ }^{2}$ Stanley, The Congo, ii. 388.
${ }^{3}$ C. 4205 , p. 5.
${ }^{4}$ C. 4205 , pp. 11 sq. ; C. 4360. 
facts of the case are simple: France was under the ministry of M. Jules Ferry,' ' whose self-imposed mission it had been to stir up trouble in every part of the world against Great Britain and to be a useful instrument for Prince Bismarck'. Prince Bismarck ${ }^{2}$ was engaged in an energetic and unscrupulous campaign to secure for Germany colonies, an aim in itself, however, not illegitimate unless the United Kingdom was to maintain a monopoly of oversea possessions and to demand that the progress of civilization should wait until she had time to annex all unoccupied Africa and administer it, a task far beyond her powers. Russia ${ }^{3}$ was pursuing a steady advance upon India, which on March 29, 1885, was to culminate after a long record of broken promises in the incident of Panjdeh, which almost resulted in war. From 1882 the question of Egypt involved with increasing emphasis the strength of the United Kingdom, and presented her with the alternative of maintaining her position there at the cost of sacrifices elsewhere to Germany or being forced to abandon Egypt. Following upon an angry dispatch from Prince Bismarck of June 10, ${ }^{4} 1884$, Count Münster in June informed Lord Granville verbally ${ }^{5}$ 'that the German Government could not maintain a friendly attitude on Egyptian matters if Great Britain maintained an unfriendly attitude on colonial questions'. In these circumstances the sacrifice of Angra Pequena and of part of New Guinea, as well as of the Anglo-Portuguese Treaty, become acts of prudent and far-seeing statesmanship, for no sane judgement can possibly compare the value of Egypt to Britain with that of Angra Pequena and New Guinea, and it may be added that in the former case the claim of the Cape to part at least of the lost territory was hopelessly compromised by the inexcusable reluctance of her ministries to accept the obligation of governing and providing for the territory which they desired to see annexed. ${ }^{6}$

1 Fitzmaurice, Lord Granville, ii. 429, 439.

2 Ibid. ii. 337 sq.; cf. Rouard de Card, Le Prince de Bismarck (1918).

${ }^{3}$ Ibid. ii. 418 sq., 440 sq.

5 Ibid. ii. 354.

4 Ibid. ii. 352 ; cf. 427 sq.

- Ibid. ii. 350, 354 . 


\section{CHAPTER IV}

\section{THE BERLIN ACT AND THE FOUNDATION OF THE CONGO STATE}

The Conference of Berlin ${ }^{1}$ met on November 15, 1884, and after an adjournment concluded its labours on February 26, 1885, with the signature of a General Act, which, defective as it has since proved, none the less marked a distinct advance in the effort of the nations of Europe to find a common basis of agreement by which to regulate their action in those parts of Africa yet unoccupied, on the basis of freedom of trade, and the amelioration of condition of the native races. Fourteen Powers sent representatives: Prince Bismarck was President, though he left the work to be done by others; the Baron de Courcel maintained France's claims with the utmost ability and resolution, while Sir Edward Mallet strove manfully to secure British interest. The other European Powers represented were Belgium, Holland, Denmark, Norway and Sweden, Austria-Hungary, Italy, Russia, Spain, Turkey, and Portugal. The United States, which had already gone far beyond its usual abnegation in matters of foreign policy, showed its good will to the Association by including Mr. Sanford in its representation, and by associating with its diplomats Stanley himself as Technical Adviser, while the Belgian representatives were aided by Colonel Strauch, and M. E. Banning, an enthusiastic supporter of the philanthropic designs of the Association, whose legal abilities had been put to good service in maintaining the legitimacy of its aims. ${ }^{2}$

${ }^{1}$ C. 4361 and 4739 ; Fitzmaurice, Lord Granville, i. 374-6.

${ }^{2}$ See his Le Partage politique de l'Afrique d'après les transactions internationales les plus récentes (1885-1888), Brussels, 1888. He had urged the 
The delegates to the Conference had the advantage of full descriptions of the nature of the situation on the Congo from Stanley and from others interested, notably the representative of the Dutch firm which had in its hands so much of the Congo trade, and had aided Stanley in his first efforts to advance up the river. Evidence was also adduced by Britain of the state of affairs on the Niger, from which by great efforts Sir George T. Goldie and his colleagues had just succeeded in securing the removal of trade under any foreign flag. Their proceedings were rendered needlessly lengthy by the great difficulty which was found in accommodating the territorial questions at stake between France, Portugal, and the Congo, for, though these matters did not lie within the scope of the Conference, it was impossible to hope for the general agreement necessary to secure a General Act until these matters were finally disposed of. Great Britain in this case threw her influence heartily into a settlement of the difficulties raised by Portugal, ${ }^{1}$ and that Power was finally compelled to come to an agreement, leaving the way open for the signature of the Act. The United States, however, had already felt doubt as to the wisdom of its new step, and so clear was it that the Act could hardly receive ratification by the Senate that it was agreed not to consider this fact any impediment to ratification by the other Powers, and all the other signatories in due course formally ratified the Act. ${ }^{2}$

The importance attached to freedom of trade by the signatory Powers is reflected in the prominence of the position assigned to this topic in the Act. Absolute freedom of trade was pronounced by Article I of the first of its seven chapters in the basin of the Congo, defined by the watersheds of the Niari, Ogoué, Shari, and the Nile on the north, the eastern watershed line of the affluents of Tanganyika on the west, and the watersheds of the Zambezi and the Loge on the south. In deference largely to the suggestion of Belgian Premier, Frère Orban, in 1884 to claim the Congo for Belgium; Masoin, Histoire, i. 38.
${ }^{1}$ C. 4361, p. 254.
${ }^{2}$ C. 4739 , p. 25. 
Stanley, the principle of free trade was more widely extended than had perhaps at first been contemplated by the Powers. It was made to apply also to the maritime zone extending from $2^{\circ} 30^{\prime} \mathrm{S}$. lat. along the Atlantic coast to the mouth of the Loge, the northern boundary to run along that parallel to the geographical basin of the Congo, but avoiding the basin of the Ogoné, which France insisted on excepting from the régime of the Act, and the southern boundary to follow the Loge to its source and thence to proceed east to the Congo basin. On the east of Africa the free-trade zone was to run from the Congo basin to the Indian Ocean at lat. $5^{\circ} \mathrm{N}$., then to extend to the mouth of the Zambezi, up which river it was to run to a point five miles above its confluence with the Shiré, and thereafter to follow the watershed of the Zambezi and Lake Nyasa up to its intersection with the watershed of the Zambezi and Congo, though the operation of this arrangement was to be conditional on the assent of Zanzibar being obtained. Articles II-IV reiterated and enforced the doctrine of freedom of trade by asserting absolute freedom of navigation on the Congo and its affluents and on canals constructed to unite them, by forbidding differential dues, and dues on import and transit, and permitting only such taxes to be levied on imported wares as represented fair compensation for expenditure in the interest of trade, though the Powers reserved to themselves the right to determine after twenty years if this condition of affairs was to continue. By Article $\mathrm{V}$ the grant of a monopoly or favour of any kind in matters of trade was absolutely forbidden, and foreigners were assured protection of person and property, and equal rights with nationals of acquiring movable and immovable property and of exercising professions. Article VII applied the principles of the Postal Union to the territory under the free-trade régime.

These provisions were completed by an elaborate navigation act for the Congo (Chapter IV). This Act reiterated the provision that charges levied on transport on the river should be based on services rendered, such as harbour, pilot,

1 Stanley, The Congo, ii. 395. 
lighthouse, beacon, and buoy dues. The affluents of the Congo, roads, railways, and canal made to remedy its defects for navigation purposes were brought under the same régime, the tolls to be collected to be based on the cost of construction of the works, and their management and maintenance and of the profits due to the promoters-the Act, however, rendering this provision almost nugatory by not indicating the margin of profit to which the promoter might be deemed entitled. The carrying out of the provisions as to navigation was to fall into the hands of an International Commission, which might also be used as arbiter in the case of disagreement between the signatory powers on matters arising under Chapter I of the Act, but, for some reason on which history is silent, the terms of the Act regarding the creation of the Commission were left in abeyance.

In comparison with the space allotted to trade, that ascribed to the question of the treatment of the natives makes little show. The terms of Article VI of Chapter I, however, were wide and generous: the Powers bound themselves to watch over the preservation of the native tribes, and to care for the improvement of the conditions of their moral and material well-being, and to help in suppressing slavery, and especially the slave trade. They were, without distinction of creed or nation, to protect and favour all religious, scientific, or charitable institutions and undertakings created and organized for these ends, or which aimed at instructing the natives and bringing home to them the blessings of civilization. Missionaries, scientists, and explorers were likewise to be the objects of especial protection. Freedom of conscience and religious toleration were expressly guaranteed to the natives, no less than to subjects and to foreigners. The free and public exercise of all forms of divine worship and the right to build edifices for religious purposes, and to organize religious missions belonging to all creeds, was not to be limited or fettered in any way whatsoever. These general principles were supplemented by Chapter II, which laid down the obligation on the Powers exercising sovereignty in the free-trade zone 
to prevent their territories being used for the place of sale or way of transit of slaves of any kind.

A deliberate effort was also made to prevent the territories in the free-trade zone becoming the scene of warfare, the ruinous effects of which on the project of civilizing the natives was recognized, while the peculiar position of Belgium, as herself a neutralized Power, lent special force to the argument for conferring a similar status on territory which the King of the Belgians was to rule. There were, however, obvious difficulties ${ }^{1}$ in the way of any formal declaration of neutralization imposed by the Conference, and Chapter II of the Act merely imposed on the signatory Powers the obligation of observing the neutrality of any of the territories to which it applied, if the Power exercising sovereign rights in these territories had declared them neutral, and observed the rules of neutrality. In the event of any signatory Power with territories in the free-trade zone, whether they had or had not been brought under this rule, becoming engaged in war, the other signatory Powers were to use their good offices to secure the assent of the belligerents to the territories in question being treated as neutral and exempt from use for warlike purposes. By rather a bizarre application of the doctrine of neutrality, the waters of the Congo, its affluents and roads, railways and canals serving to connect them, were to be open to all nations, neutral and belligerent alike, even in time of war, with the solitary exception of the carriage of contraband.

The problem of the recognition of annexations on the African coast had ceased, before the labours of the Conference were completed, to have much actuality, for comparatively little territory remained open for appropriation, but the Conference, which took the matter more seriously than seems now to have been justified, enunciated two principles: any Power, which took possession of any tract on the African coast not included in the limits of its existing

${ }_{1}^{1}$ The Conference had no mandate to deal with any territorial question as such. 
possessions or assumed a protectorate, must notify its action to the other Powers in order that they might be able to make good any claims they might have; and an obligation was imposed on any Power holding possessions or protectorates to ensure the establishment of authority in its territories sufficient to protect existing rights, and to secure freedom of trade and transit. Moreover, as an offset to the freedom of trade on the Congo, an Act of Navigation for the Niger was provided by Chapter V, but the execution of its provisions was entrusted to France for the upper, and to Britain for the lower river, in recognition of the predominating influence which these two Powers shared over the Niger.

Clauses so wide and vague on matters of fundamental importance were bound to raise dispute, and provision was made by Article XII, oddly enough inserted in the chapter on neutrality, under which, in the event of serious disagreement arising in connexion with the territories in the freetrade zone between signatory Powers, these Powers bound themselves, before appealing to arms, to have recourse to the mediation of one or several of the friendly Powers. Finally, by Chapter VII, provision was made for the alteration, by agreement, of the Act, its acceptance by any State which desired to do so, and its ratification by the signatory Powers.

On February 23, ${ }^{1}$ on the eve of the close of the proceedings of the Conference, Colonel Strauch, as President of the Congo Association, had notified to Prince Bismarck that the flag of the Association had been recognized by all the Powers represented at the Conference with one exception, ${ }^{2}$ and formal congratulations were extended by the representatives of the signatory Powers to the new State and the King of the Belgians as its founder. On February 26, ${ }^{3}$ Colonel Strauch, acting under full powers granted by

1 C. 4361 , pp. 253-4.

2 Viz. Turkey, which accorded recognition by a convention of June 25, 1885.

${ }^{3}$ C. 4361, pp. $302,303$. 
Leopold II on February 15, notified the accession of the Association to the Act, thus completing and perfecting the work of the Conference. Real enthusiasm marked the termination of the proceedings: confidence in the nobility of the aims of the King was widespread in England, and the Act itself breathed an elevation of tone which reflected credit upon its composers.

It had, however, been no simple matter for the Association to settle with the Powers the terms of its recognition. Germany led the way by recognizing by a convention of November 8, 1884, ${ }^{1}$ the flag of the Association, accepting its right over the territories which it then claimed, and receiving in return promises of national treatment for its subjects, freedom of trade, and the passing to any Power acquiring the territories or part thereof of the obligations undertaken by the Association. Britain followed suit on December $16^{2}$ by a declaration recognizing the Association, and by a convention which agreed in substance with that concluded by Germany, but added the very important provisions that British Consular officers should be entitled to hold Consular Courts, and to exercise civil and criminal jurisdiction over British subjects within the Congo according to English law; British subjects, moreover, though bound to obey the laws in force relating to foreigners, were to be justiciable only by a British Consular Court. Similar conventions were concluded with Italy (December 19), Austria-Hungary (December 24), Holland (December 27), Spain (January 7, 1885), Russia (February 5), Norway and Sweden (February 10), and Denmark (February 23), while on that date Belgium gave formal recognition of the Association. It was less easy to arrange matters with France, which was quite determined not to allow the Niari-Kwilu to pass from its hands, and which had not abandoned its claim to a footing on the south bank of the Congo. The King recognized that he must yield : he surrendered the Niari-Kwilu, in exchange for the abandonment of France's claim on the south side of the Congo, and for a promise of good offices in the dispute

${ }^{1}$ C. 4361, pp. 263, 264.

${ }^{2}$ C. 4361, pp. 264-6. 
with Portugal. ${ }^{1}$ That Power, abandoned by France, and pressed by Britain to yield, relinquished her claim to the north bank of the Congo save for an enclave at Kabinda which she prized as the source of one of the royal titles, but retained the whole of the south bank with the inner boundary at Noki, as proposed in the abortive treaty with the United Kingdom. According to Stanley's ${ }^{2}$ reckoning the Association had yielded to France 60,366 square miles, and to Portugal 45,400 square miles, but in return it had obtained the goodwill of the two Powers and 600 miles of territory on the north bank of the Congo between Boma and the sea, to which it had not, it seems, established any independent title. The final settlement of the terms of these treaties ${ }^{3}$ produced a slight anomaly, for the earlier treaties had been based on the territorial claims of the Association, which asserted truly its right to the Niari$\mathrm{K}$ wilu, but any defect which might be regarded as existing on this score must be deemed to have been removed by the decision of the Conference on February $23^{4}$ to attach to the Protocol of its session the text of all the treaties, which must thus be deemed to have been regarded as proper to be interpreted as a consistent whole.

Curiously enough, the paraphernalia of internationalism which surrounded the birth of the new State appears to have proved misleading even to contemporary jurists. M. Rolin Jacquemyns, ${ }^{5}$ founder of the Institute of International Law, is credited with the definition of the status of the Congo as that of ' une colonie internationale sui generis,

${ }^{1}$ Masoin, Histoire, i. 348.

${ }^{2}$ The Congo, ii. 404. France emerged with 257,000, Portugal 351,500, and the Congo 900,000 square miles.

${ }^{3}$ On that with France see C. 4361, pp. 272, 273; for that with Portugal, pp. $276,277$.

${ }^{4}$ C. 4361, p. 256. The boundaries as given in the declaration of neutrality of August 1,1885, were not questioned, it may be added, by any of the Powers; cf. also C. 9054, p. 16 (remarks of Lord Kimberley, August 14, 1894).

${ }^{5}$ Cited in Le Courrier Européen, January, 1908, and criticized by Régismanset, Questions coloniales, 1900-12, pp. 201-8. 
fondée par l'Association internationale du Congo dont le généreux promoteur a été investi par la reconnaissance et la confiance de tous les États civilisés du pouvoir et de la mission de gouverner dans l'intérêt de la civilisation et du commerce général des territoires africains dans certaines limites conventionnelles'. It cannot, however, be said with any accuracy that in law the Association was given its sovereign position, which passed to the Congo State, by international. agreement: its juristic existence was due to the separate recognition accorded by the Powers, commencing with that of America on April 22, 1884, and ending - with that of Turkey on June 25, 1885; the United States, as we have seen,did not ratify the Berlin Act. But, on the other hand, the Association accepted by its adhesion the obligations of the Act, which was drawn up in view of the special position of the Association, and thus both legally and morally became subject to the full rigour of the provisions of the Act. ${ }^{1}$

1 Zanzibar later adhered, but her existence as a sovereign state was. soon to be terminated by the Anglo-German partition of her dominions; Scott Keltie, Partition of Africa, pp. 335 sq. 


\section{CHAPTER V}

\section{THE ORGANIZATION OF THE CONGO STATE}

\section{AND THE BRUSSELS CONFERENCE}

Internationalism had now served its part: it had availed to secure the King of the Belgians the unexpected and most valuable support of the United States; it had conciliated opinion in the United Kingdom, which shared also America's claim on Stanley; and it had rendered possible the success of the King's scheme for the creation of a Central African Empire. Had, indeed, philanthropy alone motived the royal action, it may easily be believed that he would have chosen this moment to reorganize the International Association of the Congo and to establish the territory on a truly international base. The King's intentions, however, were clearly shown by the fact that the full powers under which Colonel Strauch, as President, notified to the Berlin Conference the accession of the Association to the Act were granted by the King as founder alone. ${ }^{1}$ No sooner had the Act been signed than the King applied, on April 16, to the Belgian Parliament to accord to him authorization to accept the position of sovereign of the territories of the Association, a proceeding rendered necessary by the stipulations of Article 62 of the Belgian Constitution. The desired authority was conceded by the two houses on April 28 and 30, on the express condition that the connexion between Belgium and the new State was to be purely personal; and there was by no means unanimity in Belgium as to the wisdom of the new step, which, as some foresaw, would almost inevitably, though indirectly, involve Belgium in political questions from which her neutralization was intended to free her. Further

1 C. 4361, p. 303. 
time was naturally required to make certain that the final step could safely be taken, but in due course the discreet inquiries set on foot by the King assured him that the time was ripe for the formal step, and on July 19, 1885, Sir Francis de Winton, as Administrator-General in the Congo, formally announced at Banana the establishment of the Independent State of the Congo, ${ }^{1}$ under the sovereignty of Leopold II. On August 1 the King himself notified to the Powers the creation of the State, and at the same time issued a declaration placing the territory of the State as defined by the treaties with Germany, France, and Portugal under the régime of neutrality contemplated by Article $\mathrm{X}$ of the Berlin Act. ${ }^{2}$ The King purported to be acting in agreement with the Association though no formal record of this agreement was adduced, but from the first he had been practically the sole controller of that shadowy body; and no question was raised either by the Association or the Powers as to the validity of his action, though in effect it constituted him the sovereign of some 900,000 square miles of territory, and of many millions of people, ruling as absolute monarch, subject only to the restraints imposed by his own conscience, public opinion, and the positive, but vague, prescriptions of the Berlin Act, supplemented by the more precise terms of the several treaties which had been signed with the European Powers as the price of their recognition of the Association.

Confidence in the King, however, was as strong as ever, and it won a concession which was of the utmost importance for the development of the State both for good and ill. The United Kingdom had insisted in securing by its treaty the sole right to pass judgement upon its own subjects, whether in civil or criminal matters, while rendering them under an obligation to obey such laws as might be enacted with

1 'L'État indépendant du Congo', mistranslated Congo Free State. Leopold II took the style of 'Souverain de l'État indépendant du Congo'; cf. Wauters, L'État indépendant du Congo, pp. 36, 37.

${ }^{2}$ For the definition of boundaries see Hertslet, Map of Africa by Treaty (1909), ii. 552, 553. 
regard to foreigners in the territories. Italy had secured the same privilege, and it passed to all the other Powers by virtue of the wide terms of the most favoured nation treatment which each obtained, though some of the treaties were silent on this point or merely claimed the right to exercise jurisdiction pending the establishment of effective courts. Had the British exercised the right, their example would doubtless have been followed by the other Powers, and, while injustice to British and other foreign subjects might have been avoided, it can hardly be doubted, in view of the experience of Morocco and Egypt, that chaos and confusion must have overwhelmed the State in its efforts to establish an effective judicial and administrative régime. Unhappily. for the State the magnitude of the British concession seems neither at the time nor later to have been sufficiently realized.

The forbearance of the Powers, therefore, left to the King an absolutely clear field for his exertions, but the task remained a stupendous one. In the enormous areas of the State many tribes knew nothing of the Association or its agents; all beyond the Falls was in the hands of the Arab slave-traders or subject to their control, while in the northeast the decay of the power of Egypt menaced the State with the advent of Mahdist armies. The Berlin Act in its anxiety to secure the freedom of trade had left little room for taxation save of exports, and a large export trade had still to be created; rubber was as yet unimportant and ivory could yield comparatively small returns. The initial expense must therefore be borne by the King, ${ }^{1}$ since he was determined to retain the control of the State in his own hands. Prudence therefore dictated the policy of a slow advance, based on the creation of an effective civil administration on the Lower Congo, and the construction of the railway which was imperatively necessary to replace the miserable delays and difficulties of the road track and water

${ }^{1}$ It is calculated that the King spent from 1879-90 on the Congo between 10,000,000 and 12,500,000 francs; Johnston, George Grenfell, i. 451 , n. 2 . 
route to Stanley Pool. Humanity dictated the same course, for the transport of steamers, arms, ammunition, machinery, trade goods, buildings, and food supplies from the Congo mouth to Leopoldville imposed not merely an enormous strain on the royal resources, but demanded incessant and exhausting toil from natives unaccustomed to any but fitful work. It is, however, difficult to blame the King if this comparatively unambitious programme seemed to him highly unsatisfactory. Even the restless energy of Stanley had proved sometimes too slow in action for the impatient monarch, and the Belgian military officers, who now began to replace in increasing measure the somewhat miscellaneous but international assistants of Stanley, could hardly be blamed if their chief end was military glory and rivalry with Stanley's exploits of adventure. There were also weighty reasons of state for forward action: if the Berlin Conference had not laid down as a general rule that effective occupation was necessary to the validity of territorial claims, the doctrine had been enunciated in respect of occupations on the coast, and the principle was obviously capable of extension, while Britain's attitude to Portuguese claims in Africa had emphasized the practical importance of the principle in question. The Powers had made generous concessions of territory, but their good will might not be abiding, and at the very least the definitive settlement of the boundaries would raise problems in the decision of which actual occupation would tell heavily. ${ }^{1}$ Even, however, had a policy of caution been adopted, it might have been impossible to persist in it; the mature plans of Sir Frederick Lugard for the gradual establishment of cordial relations with the Mohammedan emirates of Northern Nigeria proved incapable of execution in face of the refusal of the Emirs to treat with any Power which they deemed themselves able to overthrow. ${ }^{2}$ Inevitable, however, as the King's policy may well have been, it is undeniable that it imposed a strain

1 Cf. Johnston, George Grenfell, i. 453.

${ }^{2}$ Cf. Keith, West Africa (Lucas's Hist. Geog. of the British Colonies), pp. $183 \mathrm{sq}$. 
on the finances of the State which could only be met by resort to measures fatal to the welfare of the native and the efficiency of the administration.

Hitherto the destinies of the Congo had rested with men of many races acting in more or less harmony under the supreme direction first of Stanley and then of Sir Francis de Winton. With the formal assumption of the sovereignty by a Belgian King, it was natural enough that the supreme direction should be transferred to a Belgian subject, and at the beginning of $1886 \mathrm{M}$. Camille Janssen superseded Sir F. de Winton in the capacity of Administrator-General, a title later changed to Governor-General. As was inevitable at this time, the head-quarters of the new head of the administration were fixed at Boma, while for a period he was represented on the Upper Congo by Baron von Nimptsch as Vice-Governor. History has perhaps done less than justice to the value of M. Janssen's services to the Congo at a critical period. ${ }^{1} \mathrm{He}$ possessed qualities of steady work, organization, and prudence which were more valuable than mere exploring ability, and he had beyond all else the fixed resolution to avoid the use of force, and to extend the region of effective control by means of pacific expeditions which should carry out the ideal of the Berlin Act, the opening of the country to trade, and should create a spirit of attachment to the State. This policy, he argued, would stand in good stead in the conflict with the slare-traders, which he recognized to be inevitable, but which, he held, must be deferred until such time as the enterprise should be within the power of the State without neglecting its more immediate task of development, a view which Stanley himself had accepted in the beginning of 1884, when he deprecated General Gordon's aspirations to turn the Congo into the base of operations against the slave-traders of the Nile.

Stanley had never wearied in his emphasis on the necessity of the establishment of railway communication between the

${ }^{1}$ Cf. his own account of his policy in La Pénétration de la Civilisation au Congo Belge (Bulletin de la Société Belge d'Études Coloniales, Nos. 7-8, July-August, 1914), pp. 72-5. 
Lower and the Upper Congo ; ${ }^{1}$ he had confidently expected that the work of construction would have been placed in the hands of an international company, and thanks to his efforts in November, 1885, English capitalists were induced to form a syndicate in order to promote a company for this purpose. On July 24, 1886, the matter had been carried as far as the negotiation of a contract between the State and the Royal Congo Company to secure the construction of the line, but the fulfilment of this arrangement was prevented by the growth under the royal auspices of the feeling in Belgium against international interference in an undertaking which was held out to be especially Belgian. The ostensible leader of the agitation was Captain Thys, who had been associated with the Congo Association, and who succeeded in securing the foundation of a Compagnie du Congo pour le Commerce et l'Industrie. In March, 1887, a new arrangement was entered into with this company for the construction of the railway, and on November 4, 1888, a start was made with preparations for the construction of the line which, as finally decided upon on Captain Zboinski's advice, was to run entirely within Congo territory on the south bank from Matadi to Leopoldville, while the old road and steamer route had used the north bank. Further negotiation resulted in the creation on July 31, 1889, of the Compagnie du Chemin de fer du Congo, with a capital of 25,000,000 francs, of which the Belgian Government had been induced to provide $10,000,000$ francs, ${ }^{2}$ and the actual construction of the line began in March, 1890, though the great engineering difficulties of the work, added to the shortage of labour and the grave mortality among the workers, who were drawn from many nations, prevented completion for eight years. ${ }^{3}$ In the

1 The Congo, i. 463, 464 ; ii. 367-71.

2 At $3 \frac{1}{2}$ per cent. interest. The vote was approved by the Chambers on July 23,1889 . An additional five million was later accorded by an agreement of March 27, 1896; that agreement, modified by agreements of April 6,1898, and November 12, 1901, provided for the possibility of governmental acquisition in 1916.

${ }^{3}$ See Masoin, Histoire, i. 357-79. 
meantime the State organized an effective service of porters, established a shipping service on the Upper Congo and post and telegraphic communication, while steps were taken to improve the steamship service with Europe.

Even before Sir F. de Winton left the Congo there had been a forecast of the difficulties which were to be experienced in settling the boundaries. The treaty with France of February 5, 1885, had determined the boundary as following the Congo above Stanley Pool to a point to be fixed up the stream of the river Licona-Nkundja, thence to $17^{\circ} \mathrm{E}$. long., following as closely as possible the water-parting of the basin of the Licona-Nkundja, which was to form part of the French possessions, and thereafter following the $17^{\circ} \mathrm{E}$. long. From the sea to Stanley Pool the line was to follow the river Chiloango to its most northerly source, the crest of the water-parting of the Niari-Kwilu and the Congo to the meridian of Manyanga, a line following the natural division of the ground to a point on the Congo between the station of Manyanga and the cataract of Ntombo Mtaka where the river was navigable, the Congo, and the central line of the Pool. The delimitation commission sent out to determine the frontier as defined in the treaty agreed on a line in the vicinity of Manyanga (November 27, 1885), but came to no agreement as to what stream was designated as the Licona-Nkundja, by which the French contended that the Ubangi was meant. The dispute was carried to Europe, and so irreconcilable were the contending views that in July, 1886, it was agreed to refer the matter to the arbitrament of the President of the Swiss Confederation. But events induced the King to yield; he was anxious to secure that on his ceasing to be sovereign the State might fall into the hands of Belgium, and to this the right of pre-emption accorded on April 23, 1884, might be deemed to stand in the way; moreover, he desired to have quoted on the Paris Bourse the lottery loan for 150,000,000 francs which he had induced the Belgian Parliament to authorize. France was ready to come to terms, and a Convention of April 29, 1887, accepted the French contention that the Licona-Nkundja 
was the Ubangi, while other agreements of the same date made it clear that the right of pre-emption of France did not preclude the transfer of sovereignty to Belgium and opened the way for the quotation of $80,000,000$ francs of the loan on the Bourse. ${ }^{1}$ The further definition of the boundary, however, was still left vague, both parties doubtless being unwilling to commit themselves for the time being.

The treaty with Portugal of February 14, $1885,{ }^{2}$ had been precise in the extreme with regard to the limits of the enclave of Kabinda, with which the Portuguese were familiar, but the boundary south of the Congo was defined merely by the vague words, the parallel of Noki to its point of intersection with the Kwango, and thereafter the course of the $\mathrm{K}$ wango, a vagueness motived by the fact that Portugal at that period had penetrated only a very short distance into the interior of the territory which she claimed to possess. It was important for the State to secure that these vague boundaries should be defined as soon as possible, both as a precaution against claims by Portugal and in view of the activities of British exploration ${ }^{3}$ under the auspices of the Chartered Company which was constituted in 1889, and which had been preceded by independent adventurers. Wissmann as early as 1885 was instructed to form the station of Luluabourg, and in 1889 M. Janssen established a post at Lusambo. In the following year relations with Portugal became decidedly strained when, as a result of an expedition under the enterprising Dhanis, who entered into treaties with many native chiefs, Leopold II created the new district of East Kwango. The Portuguese Government formally protested that its boundaries were being invaded, and strengthened the protest by the sending of a gunboat to Boma, which was manifestly unprepared to resist such a form of attack, and the State retaliated by the creation of, a fort at Shinkakasa in order to defend the capital from

${ }^{1}$ See Masoin, Histoire, i. 348-50 ; Hertslet, Map of Africa by Treaty, ii. $567-9$.

${ }^{2}$ Article III ; C. 4361, p. 276.

${ }^{3}$ Cf. Scott Keltie, Parlition of Africa, p. 447. 
insult. Arbitration by the Pope was suggested, but ultimately a treaty of May 25, 1891, ended the dispute. Under it the boundary follows the Kwango from $6^{\circ} \mathrm{S}$. lat. to $8^{\circ} \mathrm{S}$. lat., then that parallel to its intersection by the $\mathrm{Kwilu}$, then the Kwilu to $7^{\circ} \mathrm{S}$. lat., then that parallel to the Kasai, which it follows to its affluent from Lake Dilolo; that affluent it follows to its source, and then runs along the watershed of the Congo and the Zambezi to $24^{\circ} \mathrm{E}$. long. ${ }^{1}$ It is of interest to note that it was to the missionary, George Grenfell, ${ }^{2}$ that the King entrusted the duty of marking out the boundary in co-operation with Portuguese Commissioners: the work was carried out in 1892-3, and the definitive line finally decided upon by a treaty of March 24, 1894. The minor points which had arisen as to the precise line at Kabinda and in the region of Noki had been disposed of by treaties of May 25, 1891, contemporaneous with the settlement of the Kwango dispute.

While M. Janssen's aims at peaceful penetration were thus happily successful both in the north and the south, difficulties of more serious character had arisen in the east. Stanley had secured the establishment of a station at the Falls as an outpost of civilization and a warning to the Arabs of the Upper Congo not to repeat their slave raids on the river below the Falls. Not unnaturally the Arabs were unwilling to see their activities thus curbed: the station was weakly guarded, and a savage attack in August, 1886, resulted in its destruction; Deane, a relative of Sir F. de Winton, who was in charge, with great difficulty effected his escape after a gallant struggle, and his Belgian colleague was killed. ${ }^{3}$ The position of the State was difficult in the extreme: it lacked the forces and money for a formal campaign, and, what was even more important, Stanley, who might otherwise have been appointed to the task, had other

1 Hertslet, Map of Africa by Treaty, ii. 592 sq.

2 Johnston, George Grenfell, i. 187-220 (with map).

${ }^{3}$ Masoin, Histoire, ii. 110-16; Stanley; Autobiography, pp. 345, 346, censures his lack of skill in provoking the attack by affording protection to an Arab woman who fled to the post for protection. 
calls on his attention. Since the fall of Gordon, Emin Pasha had been maintaining himself with difficulty in Equatoria; his appeals for aid had reached Europe, and the demand that aid should be sent to him was universal. Stanley was selected to lead an English expedition to his relief, and, while the choice between an east coast or west coast route was still unsettled, the King, who retained a call on Stanley's services, put pressure on him to choose the Congo route, and, while aiding Emin, to seek a solution of the difficulties with the slave-traders. In return the King offered to place at the disposal of the expedition, the funds of which had been raised in England, the resources of the State. The adoption of the royal proposal was recommended also by the jealousy - which Germany would almost certainly have felt in the passage of such an expedition through territory in which Germany was interested, and France had fears lest the expedition should result in endangering the position of her missionary stations in East Africa. ${ }^{1}$ Stanley, therefore, with the consent of the Committee by which the funds had been raised, decided to accept the proposal of the King, though the expedition remained solely under his control, and used the Egyptian flag. ${ }^{2}$ After a short stay at Zanzibar in February, 1887, when he made an agreement with Tipu$\mathrm{Tipu}^{3}$ to ${ }^{\circ}$ provide carriers for the expedition and induced him to accept service under the Congo State as Vali at the Falls, charged with the duty of maintaining order with the aid and advice.of a representative of the State, he proceeded to the Congo and made the necessary preparations for his formidable task. The difficulties of his advance through the hitherto unknown Aruwimi forest were colossal, but his discoveries, which included that of Ruwenzori and of Lake Albert Edward Nyanza and the Semliki river, were of the highest importance, and his perseverance was rewarded by

1 Masoin, Histoire, ii. 233. Stanley's own account is given in his In Darkest Africa, and his Autobiography, pp. 353-75.

${ }^{2}$ Stanley, op.cit. i. 50; Masoin, op. cit. ii. 235, n. 1.

3 A nickname of Hamed bin Muhammad bin Juma, whose life is described by Dr. Brodie, Tippoo Tib (1906). 
meeting Emin on April 29, 1888. Emin proved somewhat ungrateful for his rescue, and unwilling to make up his mind on any course. Stanley offered either to take him and his followers back to the Congo, and thereafter to Egypt, or to place Equatoria under the sovereignty of the King of the Belgians, making Emin governor and assuring him the necessary supplies, or to establish him as an officer of the British East Africa Company to the north-east of Lake Victoria. Emin procrastinated, his officers mutinied, disasters ensued, and in despair of an amicable agreement Stanley ended the whole matter by assuming command of the faithful remnant of Emin's forces, and after great difficulties succeeded in bringing them back to the Congo in December, 1889. Unhappily grave disaster had befallen his rearguard at the Falls under Major Barttelot, which had probably been saved from extermination only by the loyalty of Tipu-Tipu, and the mismanagement of this episode cast a gloomy shadow over the success of a remarkable expedition.

Stanley's agreement with Tipu-Tipu had served the State admirably; in 1888 it had been possible for Van Gèle and Van Kerckhoven to establish a new military station at the Falls, and at the end of 1889 Lieutenant le Clément de Saint-Marcq was stationed at Kasongo as Resident among the Arabs. It was also possible to push expeditions under Van Gèle, G. le Marinel, and Hanolet up the Ubangi, Banzyville being reached in 1889, and the way was paved for the decisive attacks on the slave-traders, the conquest of the south, and the advance to the Nile which were to occupy the strength and exhaust the resources of the State for the next ten years.

The necessity of securing additional sources of revenue was only too painfully obvious, and the means of meeting this need were twofold. In the first place the King turned to Belgium, where enthusiasm for his project had gradually been growing, and in April, 1887, secured the authority of Parliament for the issue of a Congo lottery loan of 150,000,000 francs, of which only some 98,000,000 francs appear to have been successfully issued. A couple 
of years later Belgium gave aid to the railway project to the extent of $10,000,000$ francs. But the expenditure was growing steadily, and by 1889 had reached $3,000,000$ francs, while, apart from the King's own subventions, only 500,000 francs of income were available. The King appealed to his ministry, which proved complacent; public enthusiasm was excited by the publication of the royal will, dated August 2, 1889, ${ }^{1}$ which made it clear that on the sovereign's death the Congo would pass to Belgium, and an agreement between the State and Belgium of July 3 received approval from the Chambers on August 4. Belgium agreed to generous terms : the State was to receive a loan of $25,000,000$ francs, a fifth at once and the rest in ten annual instalments of equal amount: six months after the payment of the last of these Belgium could choose between repayment or annexation without conditions; in the latter event the King magnanimously waived repayment of the sums expended by him on the State.

A second source of revenue was obviously the removal, or modification, of the restriction which forbade the imposition of import duties. Fortunately for the King the popular sentiment in favour of the suppression of the slave trade, which had been fanned by the energetic campaign of Cardinal Lavigerie, ${ }^{2}$ undertaken with the sanction of Pope Leo XIII, suggested a means of reopening the question before the expiry of the twenty years' period contemplated in the Berlin Act. Public opinion in England induced the British Government to propose to Leopold II to undertake the summoning of a Conference at Brussels to investigate the question-a step necessarily involving consideration of the means of carrying out a campaign against the trade. Seventeen Powers shared in the Conference, which assembled at Brussels in November, 1889, and the United Kingdom took the opportunity of laying stress on the question of the liquor traffic, in which she had found it impossible to

1 Text in Masoin, Histoire, i. 189, 190 ; cf. É. Payen, Belgique et Congo, pp. 24; 25.

2 Masoin, op. cit. ii. 61-81. 
interest the Berlin Conference. ${ }^{1}$ There was apparent from the first serious difference of views among the Powers: Germany was not anxious that the profitable trade in liquor should be hampered; Holland was resolutely opposed to interference with the profits of the. Dutch house on the Congo; France developed a high degree of sensitiveness to the exercise of the right of search by other than national vessels of ships suspected of being engaged in the slave trade. Agreement was reached, with great difficulty, on July 2, 1890, ${ }^{2}$ but ratification in France and Holland was long delayed, and the Act became effective only on April 2, 1892, and even then with reservation by France of the question of the right of search. ${ }^{3}$ As was natural, the main emphasis of the Act was laid on the suppression of the slave trade: the regions in which it originated were to be put under strict control (Chapter I), caravans of slaves were to be intercepted and the slaves set free (Chapter II), the seaborne slave traffic was to be stopped (Chapter III), and the Powers which still permitted domestic slavery were to forbid the importation of slaves (Chapter IV). An International Maritime Office was to be established at Zanzibár charged with duties regarding the interception of sea-borne. slave traffic ; the Powers arranged to communicate information to one another, and to provide for the treatment of released slaves (Chapter $\mathrm{V}$ ).

On the liquor traffic important decisions were also taken, and for thispurpose there was created an artificial zone bounded by the ocean on either side, with its northern boundary at $20^{\circ} \mathrm{N}$. lat. and the southern at $22^{\circ} \mathrm{S}$. lat.; in those districts within this area in which, for religious or other

1 Cf. C. 4284 , p. 7 ; C. 4360, p. 2.

${ }^{2}$ C. 6048 and 6557. Cf. Masoin, Histoire, ii. 72-9.

${ }^{3}$ See Articles XXI-XXIII and XLII-LXI, C. 6557, pp. 101, 102. The Act was adhered to by Ethiopia, Liberia (1892), and the Orange Free State (1896). It was signed for the United Kingdom, Germany, AustriaHungary, Belgium, Denmark, France, Holland, Norway and Sweden, Italy, Portugal, Russia, Spain, the United States, the Congo, Turkey, Persia, and Zanzibar. 
reasons, the use of distilled liquors did not exist or had not been developed, the importation and distillation of such liquors was to be forbidden. In other districts there was to be levied a duty of not less than 15 francs a hectolitre at $50^{\circ}$ Centigrade, which might be increased after three years to 25 francs, while the whole question wàs to be reconsidered in six years; equivalent excise duties were to be levied on distilled spirits.

Finally, by a declaration which was signed at the same time as the Act, it was agreed that Powers having territories in the free-trade zone as defined in the Berlin Act should be at liberty to levy import duties, the rate not to exceed ten per cent. ad valorem on the value of the goods at the port of entry, save of course in the case of liquor duties, which were to be regulated by the Act. It was also contemplated that a general set of customs regulations should be drawn up, but the intention was never carried into effect. This was, of course, by far the most important part of the Act in the eyes of the King, and immediate steps were taken to draw up the necessary customs tariff, though, owing to subsequent changes in policy, this source never yielded the amount of revenue which had been expected.

Of the details of the Act special importance attaches to the provisions made to deal with the trade in fire-arms, which the Act declared to be playing a pernicious and preponderating part in the carrying on of the slave trade and in the intestine wars of the natives in the interests of whom the Act was agreed upon. It was, therefore, laid down ${ }^{1}$ that the importation of fire-arms and ammunition should be prohibited within the area between the two seas stretching from $20^{\circ} \mathrm{N}$. lat. to $22^{\circ} \mathrm{S}$. lat. All imported arms and ammunition were to be stored in warehouses under the control of the administration of each State, and no withdrawal was to be permitted without the authority.of the administration.

${ }^{1}$ Articles VIII-XIV. By a decree of March 10, 1892, Leopold II forbade the trade in arms in the Congo, permitting only the use of flint guns in the Lower Congo. On July 1, 1891, he had elaborated the law against slave trading. 
The Governments concerned might permit at the seaports the opening of warehouses for the sale of flint-lock unrifled guns and common gunpowder, the so-called 'trade powder', but the sale of even these articles in the slave-trade districts was absolutely forbidden, and it was left to the discretion of each administration to limit as it pleased the sale elsewhere. Weapons of precision, such as rifles, magazine guns, and breech-loaders, with their ammunition, were only to be withdrawn from the Government warehouses for the purposes of the armed forces of the State, and for delivery to such private persons approved by the State who could give guarantees that the arms and ammunition in their hands would not be allowed to pass in any way into the keeping of third parties, and to travellers who could produce declarations from their Governments that the arms and ammunition required were solely for personal defence. In such cases licences for five years, renewable, but liable to withdrawal if abused, were to be issued to the holders, and the arms in their possession stamped.

The Act provided also that in the event of a Power having possessions or protectorates inaccessible by sea without traversing territory in the possession or under the protection of another Power, the former Power should have the right to free passage across the territory of the other of arms and ammunition which it certified to be essential for its armed forces, for the protection of missionary or commercial stations or of persons named by it; but the maritime Power was accorded the right exceptionally and provisionally to refuse permission even in such an event for transit if it considered that this could not be effected without endangering its own safety. The Powers also undertook to keep one another informed of the measures taken by each for the repression of the trade in arms, and the agreement was to last for twelve years in the first place, subject to renewal for two years unless any of the Powers had signified withdrawal or requested revision of its terms within twelve months before it was due to expire, and so on for a period of two years from time to time. 
The liberty of raising import duties conceded by the Brussels Act was followed by an agreement of April 8, 1892, between France, the Congo, and Portugal, setting up a uniform tariff for the customs and exports duties in the western part of the Congo basin, a decision largely motived by the fact that the river formed the common boundary of these States for a considerable distance, and that parts of the French territory were more easily reached through Belgian territory, while Portugal had no ports on its side of the river and used instead those of the State. This arrangement, renewed from time to time, finally terminated on July 2, 1911, at the instance of France, which held that with the development of the French Congo the arrangement had ceased to be advantageous, and which desired to press for the reopening of the question of the rate of taxation permitted. ${ }^{1}$ The terms of the liquor clauses of the Brussels Act were, in accordance with its terms, submitted to revision by a second Conference, which met at Brussels in 1899, and agreed upon a Convention on June 8. ${ }^{2}$ Under the revised terms the rate of duty was raised to 70 francs per hectolitre at $50^{\circ}$ Centigrade, with proportional increases for each degree above that standard, and permission to decrease for each degree below : in the case of Togoland and Dahomey the duty was exceptionally to be fixed at 60 francs. The excise duties levied on distilled drinks made in the regions into which import was permitted were to be raised to figures to correspond with the increase of the import duties. As in the case of the Brussels Act of 1890, the new rates were to endure for six years and then to be revised, and a Convention of November $3,1906,{ }^{3}$ agreed upon in accord with this principle, fixed for a period of ten years the import duty at 100 francs generally, but 70 in the case of Erythrea, and increased the excise duties in proportion. In the case of Angola special concessions were made in order to facilitate the transfer of distilleries into sugar factories. In this case

1 Lannoy, L'Organisation coloniale belge, pp. 185, 186.

2. Cd. 103.

${ }^{3} \mathrm{Cd} .3264$ and 3856. 


\section{ORGANIZATION OF THE CONGO S'TATE}

also revision of the rates was to be taken into consideration; but only eight years later; an effort to revise the figures in 1911 broke down, ${ }^{1}$ and the question remains for further consideration.

1 Keith, West Africa, p. 213. 


\section{CHAP'TER VI}

\section{THE CONQUEST OF THE KATANGA}

THE successful termination of the expedition of Stanley released the resources of the State for expansion on a large scale, and advantage was taken of the armed truce which prevailed with the slave-traders to secure the southern region of the State, known as the Katanga, from the name ${ }^{\cdot}$ of a chief who at one time controlled the vast area of territory between the Lomami and Lualaba rivers and the $9^{\circ}$ and $12^{\circ} \mathrm{S}$. lat. At the time when the State came into existence much of the country was under the power of Msiri, formerly a merchant in copper and ivory, who had married the daughter of Katanga and had succeeded his father-in-law in his political power. Msiri showed considerable ability, and in a brief period he won between the years 1883-90 a position of paramount power, deriving large profits from the slave raids with which he devastated the surrounding country. ${ }^{1}$ The foundation of the post of Lusambo by M. Janssen in 1889 was intended as a preliminary to an advance against Msiri, and the demand for action became more pressing when the movements of the explorers, Joseph Thomson and Grant, excited fears that the British advance might pass beyond the watershed of the Congo and the Zambezi, which the King's declaration of neutrality had specified as the boundary of the State. This anxiety was not without cause. On November 8, 1890, Mr. A. Sharpe, British vice-consul in Nyasaland, visited Msiri and vainly urged the chief to accept the protection of the British flag. The Belgian, Hodister, had in the same year explored the Upper Mongala and the territory between the Lualaba and the Upper Lomami; and in April, 1891, Paul le Marinel

${ }^{1}$ See Torday in Johnston, George Grenfell, i. 417-23. 
arrived at Msiri's capital at Bunkeia to negotiate a treaty with him. Msiri, however, proved as unwilling to accept Belgian as British rule or protection, but gave permission for the establishment of a Belgian post on the Lofoi, and the King resolved to dispatch Dhanis ${ }^{1}$ in the following year to secure the submission of the chief. In the meantime, however, he had been negotiating with the Compagnie du Commerce du Congo in order to secure its aid in the settlement of the south-an idea suggested, of course, by the success of the British South Africa Company, and encouraged by the fact that in 1888-9 Delcommune had already carried on explorations in the south in the interest of the Company. After long negotiations an agreement was reached in March, 1891. There was created a Compagnie du Katanga, ${ }^{2}$ which undertook to explore the Upper Congo, place two vessels on it, to establish three posts, to. open up the territory, and to carry out such administrative duties as the State might see fit to assign to its servants. In return it was granted in full ownership one-third of the lands of the State in the whole region, to be allotted in chessboard fashion in blocks of $6^{\prime}$, from the whole of the territory of the State in the basin of the Lualaba above Riba-Riba, and of the Upper Lomami. The new Company set about its work effectively: it took over control of the work already undertaken by Delcommune, and organized two further expeditions, the chiefs of which received commissions from the State to act for it in treating with the native chiefs and in securing the recognition in the Katanga of the flag of the State. In order to develop the commercial advantages secured to it, on October 21, 1891, the Katanga Company founded the Syndicat commercial du Katanga, whose sphere of action was to be the whole territory south of the Falls and of Yango on the Lomami, and the Syndicate hastened to dispatch an expedition under

${ }^{1}$ Dhanis's expedition was en route when the slave-traders' attacks caused him to be recalled.

2 The capital was $3,000,000$ francs. The Congo Company received 250,000 francs and 1,050 shares; Masoin, Histoire, ii. 199 sq. 
Hodister to establish steamers on the Upper Lualaba and to undertake the exploitation of the land of the Company, an enterprise which ended in May, 1892, in disaster at the hands of the Arabs. ${ }^{1}$

The expedition of Delcommune, originally commercial in aim, had left Matadi on September 30, 1890 : it arrived at Bunkeia on October 6, 1891, after many adventures, in the course of which it had explored large areas of country hitherto unknown. Msiri received the leader in a friendly manner, and asked his aid against a faction of his subjects who were in revolt, alienated by the cruelties of a ruler whose advancing years had deprived him of much of his terror. Delcommune declined to interfere, preferring to leave the matter in the hands of Legat, the commandant of the post at Lofoi founded by P. le Marinel, who was awaiting the return of that officer. Leaving Lofoi, Delcommune advanced south to Ntenke, whence he proceeded to the Lualaba, having decided to follow its course to Nyangwe. In this hopeless effort to combat with the rapids he persisted for six months, but was finally compelled to return in June to Bunkeia. The next six months saw him engaged in fruitless efforts to assist Jacques, who was hard pressed at Albertville by the slave-traders, and in explorations of the Lukuja and the Luapula and Lualaba, which had finally to be stopped by reason of the exhaustion of the personnel of the expedition. Delcommune had showed the greatest resolution and courage as an explorer; but his mission had been politically of little or no value, and his management of his men had been seriously lacking in skill and humanity. ${ }^{2}$

Of much greater political importance was the mission of Captain Stairs, a young English officer who had entered the service of the State in order to find a wider field for his military ambition. His expedition followed the Zanzibar route; leaving the coast on July 4, 1891, and proceeding

1 The Syndicate was liquidated, but reappeared as the Compagnie du Lomami (July 5, 1898).

2 Masoin," Histoire, ii. 201-6. 
for part of the way in company with the mission of Jacques, which had been dispatched by the Belgian Anti-Slave-Trade Society, to deal with the slave-traders to the west of Tanganyika. Arriving at Bunkeia on December 14, 1891, he found Msiri exposed to the attacks of the revolted Basanga, and in great need of assistance. The chief, however, persisted in the attitude of refusing to accept the protection of the State flag, and, on Stairs insisting on his submission on December 19, fled secretly from his capital. On the following day Stairs sent Lieutenant Bodson, the second in command, to bring him back. Bodson, entering the presence of Msiri with a few followers, found him surrounded by a large guard. Msiri seems to have menaced him; and in the scuffle which followed the chief fell, and Bodson was mortally wounded. Stairs's task was now made simple: the relatives of the chief hastened to surrender, and the territory was restored to the rule of its former rulers, each of whom was compelled to recognize the State flag and to accept the protection of the State. On January 30, 1892, Stairs, already seriously ill, handed over to Bia the completion of his work, and proceeded, via Tanganyika and Nyasa, to the Zambezi, dying, on June 8 , within sight of the Indian Ocean.

The third of the Company's expeditions had left Lusambo on November 9, 1891, and had reached Bunkeia on January 30,1892 , after a march through country desolated by the slave-traders, and afflicted by famine. On April 14 Bia, leaving Legat in charge of the fort at Bunkeia commenced by Stairs and finished under Bia, proceeded to Lake Moero, and to the south of Bangweolo, taking possession of the country for the State. He then advanced east to Ntenke, where, worn out by his exertions, he died on August 30. Francqui took charge of the remains of the expedition and, after exploring the Sankuru, brought it back to Lusambo on January 10, 1893, after a total journey of 6,000 kilometres.

Despite the cost in men, the expeditions had been of decisive value for the State, by removing any possibility 
of the advance of British influence over territory which was already believed to be rich in minerals. At the same time the enthusiasm of Bia had carried him over the upper course of the Luapula, and threatened encroachment on territory which was not within the legitimate boundaries of the State. ${ }^{1}$ A solution of the rival claims, which might have proved difficult, was facilitated by considerations affecting the future of the Nile region, and in the settlement of British and Congolese claims on May 12, 1894, was included a definition of the southern boundary. ${ }^{2}$ Under it the line of demarcation runs direct from the extremity of Cape Akalunga on Lake Tanganyika, situated at the northernmost point of Cameron Bay at about $8^{\circ} 15^{\prime} \mathrm{S}$. lat., to the right bank of the river Luapula, where that river issues from Lake Moero. The line then runs directly to the entrance of the river into the lake, being deflected, however, towards the south of the lake to give the island of Kilwa to Great Britain. It next follows the thalweg of the Luapula up to its issue from Lake Bangweolo, thence running southwards along the meridian of longitude of the point where the river leaves the lake to the watershed between the Congo and the Zambezi, which it follows to the Portuguese frontier.

It was fortunate for the State thus to secure the settlement of a question of so great importance, for the fortunes of the years immediately following precluded the State from any serious effort at the development of the territory. The influence of the State was, however, maintained by the determined effort of Brasseur, who replaced in September, 1893, Legat at Lofoi. In 1894 he opened up regular communication with Tanganyika, and defeated on Moero the Arab Simba; in 1895 he concluded many treaties; and in. the following years explored the country between the Lualaba and Luapula, dying in November, 1897, from a wound received in an attack on the Arab Shiwala. Verdick succeeded him; and in 1898 the post of Lofoi, which had

1 This appears clearly from Masoin's account, Histoire, ii. 212, 213.

${ }^{2}$ Article I (b) ; C. 7360, p. 2. 
proved unhealthy, was removed south to Lukafu, while Maréchal founded the post of Pweto on Lake Moero. Lemaire, in the course of a journey from the Zambezi to the Congo mouth in 1898-1900, solved many problems of geographical importance, especially in connexion with the distinction between the sources of the Congo and the Zambezi. Two English missionaries came in 1896 and established a station at Moena ; and Brasseur was unflagging in his efforts to extend civilization by encouraging the cultivation of wheat, rice, and potatoes, in order to avert the appalling famines which had become of regular occurrence before the advent of the power of the State, and of which the expeditions of Stairs and Bia had had personal experience. ${ }^{1}$

The relaxation of tension in the north, after 1898, rendered a more active policy possible for the State. The Compagnie du Katanga had been unable to take any effective action to develop the territories which it was supposed to have received in full ownership, since partition was an indispensable preliminary, and the State showed no anxiety to proceed to this process. A preliminary step was, indeed, taken in an agreement of May 9, 1896, ${ }^{2}$ under which the $\mathrm{Com}_{\tilde{r}}$ any resigned all claims to land north of $5^{\circ} \mathrm{S}$. lat. in return for the concession in full ownership of an equivalent area on the Lower Lomami; but this precedent was not followed in the final settlement which was embodied in an agreement of June 19,1900, after an effort, in the preceding year, to carry out a partition on the basis of the agreement of 1891 had, as was inevitable, failed ignominiously. The agreement created a Comité spécial du Katanga, which for a period of ninety-nine years was to be charged with the duty of management and alienation of the lands of the Katanga. The President of the Comite was to be nominated by the State, which was also to appoint

${ }^{1}$ Masoin, Histoire, ii. 214 sq.

${ }^{2}$ Lannoy, L'Organisation coloniale belge, p. 84 sq., where the period of ninety-nine years should be dated from 1891, as in effect on pp. 162, 163 . Masoin, op. cit. ii. 216, seems equally in error. 
three other members, and two members were to be appointed by the Company. The Comité was to undertake such administrative functions as the State might delegate to it, and to accept the obligations of the Company as regards placing vessels on the Luapula, Moero, and Tanganyika, and establishing posts. The profits of the lands were to be divided in the proportion of two-thirds to the State and one-third to the Company; and at the end of ninety years the assets were to be divided in similar proportions. The arrangement was completed by a royal decree of December 6,1900, under which the Comité was given a civil personality, and entrusted with all administrative functions in the Katanga, the State reserving to itself the control of justice, of taxation, and of the postal service.

The nature and extent of the authority thus conferred upon the Comite were illustrated by a case which occurred only five months after the issue of the royal decree. On May 14, 1901, the Austrian subject Rabinek ${ }^{1}$ was arrested on board the British vessel Scotia, while lying at anchor off the north-west corner of Lake Moero, on a charge of trading in the Katanga. He was fined $£ 40$, and sentenced to a year's imprisonment; and, on appealing to the Court at Boma, was sent thither, such imperfect preparations being made for the long journey that the unfortunate man died en route. The episode raised two serious questions: that of the legality of conferring an exclusive right of trade on the Comite in view of the prohibition of monopolies by the Berlin Act, and that of the precise position of the boundary, with the British sphere. On neither point, however, was any settlement arrived at. Rabinek seems to have pleaded in his defence not merely the Berlin Act but also a permit to trade formerly granted by a State official, Levecque; but, though there were clear grounds for diplomatic action, A.ustria did nothing. The British Commissioner of Central Africa reported on March 13, 1903, that the question of the place of arrest did not admit of definite settlement, and

1 Cd. 1536. The actual delimitation of the boundary was in progress in 1914. 
that, though it was probably within the British sphere, nevertheless the Belgian authorities might quite legitimately have believed, as did the captain of the Scotia, that the vessel was in State waters. The Company in its turn insisted that it had had no part in the matter, the sentence imposed being that of a State judge, and all judicial matters lying outside the sphere of the competence of the Comité.

The dangers of the position of the Comite were, however, evaded by the decision to accept the services of British capital in the work of developing the mineral wealth of the Katanga, which British enterprise had revealed. ${ }^{1}$ An agreement of December 9, 1900, with Mr. R. Williams, the friend of Cecil Rhodes, gave him in the first instance for five years, a period extended by a further agreement of October 22, 1905, an exclusive right of prospecting for. minerals in the south of the Katanga, and a subvention of 75,000 francs annually on condition of his expending at least 125,000 franes. This arrangement was altered in 1905 to provide for the equal sharing of the cost. The minerals discovered were to be exploited for a period, first fixed at thirty and later extended to ninety-nine years, by the Comité and Mr. Williams, the expenses being shared equally, but the Comité receiving 60 per cent. of the profits. Half the capital of such companies as might be formed to exploit the mines was to be furnished by the Comité, which was to have the right of appointing half the members of the Directorate. Mr. Williams in 1901 transferred, with the assent of the Comité, his interest to Tanganyika Concessions Limited, and the work of exploration was effectively carried out under the guidance of Mr. G. Grey, on the strength of whose work Mr. Williams asked for and obtained, by an agreement of March 22, 1902, an extension of his monopoly of prospecting on the west of the Lualaba and the gold mines of Ruwé. The final outcome of the activity of Mr. Williams was the founding on October 29, 1906, of the Union minière du Haut-Katanga, with a capital of

${ }^{1}$ Masoin, Histoire, ii. 218 sq.; R. Williams, United Empire, 1917, pp. 448 sq. ; Times, June 27, 1918. 
$10,000,000$ francs, Belgian interests being secured by the allotment to the Société générale, the nominee of the Comité, of 107,000 shares out of 200,000 . There only remained to be accomplished the construction of the necessary railway communication with Rhodesia, an undertaking which was not carried into effect until the State had definitely passed into the hands of Belgium. ${ }^{1}$

In the meantime the Comite had spared no effort to carry out effectively its administrative functions. By 1904 twenty posts had replaced the eight which existed in 1901; a police force of $1,4 \overline{40}$ men was created; roads took the place of native paths; navigation on Tanganyika, Moero, the Upper Lualaba, the Lufira, and the Luvua was facilitated; communication was opened up between the Sankuru and Moero, and the mining centres were placed in connexion with Kambove and Kasembe. Encouragement was given to the development of the rubber industry, and to the cultivation around the posts of the food necessary for the support of the stations, while the keeping of oxen both for slaughter and for use in traction was encouraged. The total result, indeed, was comparatively limited, so potent were difficulties of distance and transport, but the preparation was made for the growth of the country which was to be the immediate fruit of the completion of railway communication.

1 The difficulties of raising money for this aim are graphically described by Mr. Williams, loc. cit.; cf., however, Baron E. B. d'Erlanger's comments, pp. 461, 462, where stress is laid on the aid given by the South Africa Co. and the Beit Trustees. 


\section{CHAPTER VII}

\section{THE FALL OF THE SLAVE-TRADERS AND THE MILITARY REVOLTS}

WHILE the Katanga was being brought under the control of the State with little bloodshed, the State was engaged in a desperate struggle with the slave-traders of Manyema, whose power had become a definite menace to the future of the State. Stanley had won inestimable advantages for the early growth of the State by postponing the conflict until the State should be in a position to meet its adversaries on approximately even terms. But it,was obviously impossible to contemplate the indefinite maintenance of the artificial equilibrium which his agreement of 1887 with Tipu-Tipu had created.' It is indeed possible that, had that Sultan been the only factor in the case, the experiment of leaving the eastern part of the State under his control on the understanding that he would suppress slave-raiding might have proved successful, but, though his authority was paramount at the Falls and at Kasongo, his own capital, in the rest of Manyema his influence greatly varied in strength. It was not until 1890 that Mohara became through his aid master of Nyangwe, his rival, Said ben Abedi, retiring to Kilonga, and while Nserera, a vassal of Mohara, held Riba-Riba, Kirundu was under the independent rule of Kibongé, Kabambaré was under Moini-Hamis, and the country beyond Kabambaré was under Rumaliza, who had formerly been a vassal of Tipu-Tipu but had asserted his independent personality and fixed his capital at Ujiji on the German side of Tanganyika. To establish his own rule over the

1 Stanley claims in his Autobiography (pp. 413, 457) to have urged in April, 1890, the King to overthrow the slave-traders. 
whole area was beyond the powers of the Sultan, and the careful inquiries of M. Janssen in 1889-90 revealed the fact that, while in the vicinity of the posts the Arabs showed themselves peaceful and friendly, in the interior of the country the old slave raids were in active operation. The State prepared itself gradually for a contest which was obviously unavoidable, and between 1888-90 a series of posts was drawn from the Uele to the Sankuru to keep the Arabs within the boundaries of the. Aruwimi and the Lomami which had been assigned to them, though with some inconsistency Tipu-Tipu had been given as part of the price of his support the right to trade in ivory in any part whatever of the State territory. The last chance of the continuance of the peace disappeared in January, 1890, when, on the succession of the Sultan Said Kalifat to Said Bargash, TipuTipu was recalled to Zanzibar by the new Sultan, whose suzerainty he had never repudiated, whatever hopes he may have entertained of at some time founding an independent kingdom. En route he appealed at Nyangwe to the chiefs to respect the State flag and to live at peace with the State, and he secured the recognition by the State of his nephew Rachid as his successor in his obligations to the State, protesting to the Resident at Kasongo his devotion to the King. His motive in this withdrawal has been variously interpreted, but the probability is certainly that, foreseeing the inevitable outbreak of hostilities, he preferred to remove himself from any participation in them. ${ }^{1}$

The Arabs, however, were far too lacking in unity to take up at once the challenge of the action of the State in its preparations for war, and their supineness resulted in the acquisition by the State of an invaluable ally. The territory between the Lomami and Sankuru had been conquered by the Arabs, but they had contented themselves with assigning it to Pania Mutembé and Lupungu, two native chiefs who had adopted their cause and outdid them in atrocity. These chiefs displayed a tendency to make their peace with the growing power of the State, and in August, 1890, Gongo

${ }^{1}$ Cf. Masoin, Histoire, ii. 127. 
Lutété, formerly a slave of 'Tipu-Tipu and now commandant of his advance guard at Gandu on the Lomami, advanced to recall the chiefs to their allegiance. Descamps, then in charge of Lusambo, warned Gongo not to persist, in his course of action, pointing out that he had already done wrong in crossing the Lomami, and, when Gongo declined to obey him, attacked his camp with such energy as to win a brilliant victory. This was followed up in the following year by further steps to overawe the resistance of the tribes, and Kichimbi, a vassal of Gongo's, was won over. In 1892 Gongo himself reappeared to check the forces of the State; Dhanis, who had taken over charge of the Lualaba district, advanced against him, and defeated him in three desperate engagements from April 23 to May 9. This experience induced Gongo to throw in his lot with the State; the Arabs, despising him on the score of his origin, had given him no help in his campaign, and Dhanis by a visit to Gandu' in September succeeded in obtaining from him an undertaking of loyalty to the State in exchange for the recognition of his control over Gandu and its adjoining territory. The value of this agreement was shortly to receive the most remarkable proof.

As was inevitable with chiefs so poorly organized as the Arabs, the actual outbreak of the war was unpremeditated, and was provoked by circumstances more or less accidental on the very day of the third and conclusive victory of Dhanis over Gongo Lutété. The Arabs had learned as early as 1889 of the anti-slave-trade campaign of Cardinal Lavigerie, and their disquiet had been increased by the German pressure from the east, which became marked in 1888. Thence resulted a steady concentration of the slavetrade power in Manyema, the traders removing their captives thence from the eastern shore of.Tanganyika. As a counterblow the Belgian Anti-Slave-Trade Society, after its activities had been brought into harmony with those of the State by the Brussels Conference, decided to secure the establishment of posts on the State side of the Lake, and the expedition of Jacques in 1891 resulted in December in the founding of 
Albertville on Tanganyika, a result rendered possible only by the aid given by Germany, which had, in furtherance of its own campaign against the Arabs, facilitated in every way the advance of Jacques from the eastern coast. To this menace was added the decision of the State to interfere in the ivory trade, whence the Arabs had derived hitherto so much profit. Jacques received instructions, which he could not carry out, to tax caravans passing south of Tanganyika, and Van Kerckhoven in January, 1892, took no less than 1,200 tusks of ivory from the followers of Rachid and of Sefu, son of Tipu-Tipu, who were operating in the north under the authority formerly conceded by the State to TipuTipu. Rachid and Sefu, indeed, were too much under the influence of the power of the State to head rebellion, but the case was different both at Nyangwe and Riba-Riba, where the power of the Belgians was only faintly realized.

At this moment occurred the ill-fated expedition of Hodister, sent by the Syndicat commercial du Katanga to obtain ivory and to establish stations for trade at Nyangwe, Riba-Riba, Kasongo, and in the Katanga. Hodister's mission, which reached Isangi at the confluence of the Lomami and Congo on March 11, 1892, then split up into two, Hodister following the Lomami, and his subordinate Jouret proceeding up the river. Friction at once arose with the representative of the State at the Falls, Tobback, who forbade the expedition to trade in ivory and warned them of the danger of irritating the Arabs by efforts to deflect the ivory trade to the Congo route in lieu of that by the east coast, while himself taking steps to create at Riba-Riba a State post under Michiels, in opposition to the commercial factory entrusted by Jouret to Noblesse. The combination of events appears to have worn out the patience of the Arabs : on May 9 both Michiels and Noblesse were murdered at Riba-Riba, Hodister met the same fate on May 16, and by the end of June, of seventeen members of the two expeditions ten had fallen, and every post occupied had been abandoned. The whites at the Falls were, however, preserved from destruction by the loyalty of Rachid and Sefu, who still 
protested devotion to the State. Lippens and de Bruyne, however, were made prisoners at Kasongo, where they were posted as representatives of the State with the Arabs, and the chief Kibongé showed his complicity in the rising by securing the assassination of Emin Pasha at Kinena, on his arrival in the Congo from exploration in the neighbourhood of 'Tanganyika.'

The news of the submission of Gongo decided the action of Sefu, who hastily quitted the Falls to rally his forces at Kasongo, while Dhanis was gathering his forces at Lusambo. Sefu's demands were the head of Gongo and the boundary of the Lomami, and, when these conditions were refused, he crossed that stream, only to suffer a disastrous defeat on November 22. Four days later Dhanis began a systematic attack on the Arab territories, which unhappily evoked the revenge of the assassination on December 1 of de Bruyne and Lippens. Whatever chance the Arabs had of successful resistance disappeared in January, 1893; with the death in battle of the brave Mohara, who had been the life and soul of the revolt. Delay, however, ensued in decisive action by Dhanis, partly, doubtless, because of conflicting instructions from the Government, which was not clearly resolved on a forward policy. On March 4, however, he obtained possession of Nyangwe, which the Arabs had stealthily abandoned, and on April 22 became by assault master of Kasongo, Sefu's stronghold, and of a vast booty, including twenty-five tons of ivory. ${ }^{2}$ The granaries of the city, which the Arabs had no time to empty, were full of rice, coffee, and maize; the gardens were filled with fruit, and sugar-cane was cultivated on a large scale, as well as maize and rice, the work of slaves having been employed to clear the forest. The vast numbers of slaves thus liberated were settled on the land under chiefs

1 The date is uncertain, apparently on October 23, 1892 ; Masoin, Histoire, ii. 140, n. 1. Emin had been in German employment since 1891, and in his later days worked for Germany, and apparently was guilty of much savagery ; Stanley, Autobiography, pp. 374, 375.

2 The destruction of these places is admitted by Hinde in his address to the Royal Geographical Society, March 11, 1895. 
chosen from the Arabs who submitted or from the Zanzibaris among Dhanis's soldiery, and the tribes thus constituted were assigned lands and provided with seeds. There was imposed on them the obligation of furnishing men for the State forces and for such public services as might be exacted, and the chiefs undertook to obey the orders of the State authorities.

The work of Dhanis was supplemented ably by Chaltin, commandant of the camp at Basoko, who from March to May carried out effective operations against the Arabs based on Riba-Riba, preventing their co-operation with their brethren in the south, and by Ponthier, who from June to September harried the remnants of the Arab forces under Rachid and Kibongé." But this month saw a grave loss to the Belgian forces in the disgraceful judicial murder by Duchesne of Gongo Lutété, who had returned to Gandu after his share in Dhanis's victories. The charge of treason on which Duchesne acted was frankly incredible: ${ }^{1}$ had Gongo desired to destroy the Belgian forces he had had opportunity enough, and they in fact owed their success to his aid and to his remarkable military capacity. Peculiar horror was lent to the murder by the courage and high spirit of the victim, who sought to commit suicide when his sentence was pronounced, but was prevented from doing so. Dhanis happily had no share in the crime; he had indeed sent Hinde, an English doctor who served throughout the campaign and who forms one of the chief authorities for its details, ${ }^{2}$ to prevent any hasty action, but despite Hinde's efforts he arrived too late. The removal of Gongo resulted in anarchy in the territory he had ruled, which was quelled, though only for the time, by the arrival of Gillain, who inquired into the circumstances, and appointed.Gongo's son, Lupungu, to take his father's place.

Dhanis, deprived of the aid of Gongo and his followers, made energetic efforts to collect reinforcements to complete the work of subjugation. Ponthier joined forces with him

${ }^{1}$ Masoin, Histoire, ii. 157.

2 The Fall of the Congo Arabs (1897): 
on September 28, but the danger from the Arabs was at the same moment enormously increased by the advent in the field of Rumaliza, who had hitherto been engaged in holding effectively in check on Tanganyika the forces under Jacques, but had now been driven from Ujiji by the German advance. The three thousand men of his forces were increased by the remnants of the forces of Rachid and Sefu and took up strong positions in bomas, or fortified camps, between the Lulindi and the Luama affluents of the Lualaba. Four months of campaigning followed, during which the Belgian forces suffered more than one reverse, but on January 14, 1894, thanks to the happy accident by which a shell set on fire the magazine of Rumaliza's boma, the Arab cause suffered irreparable defeat. On January 25 Kabambaré fell into Belgian hands; shortly after the State forces joined hands with those of the Anti-Slave-Trade Society on Tanganyika, and by April Rachid and Nserera, with other chiefs, were prisoners ; Kibongé, who refused to yield, was captured next year in the Aruwimi and executed, and Rumaliza alone of the chief leaders of the Arabs escaped into German territory.

Dhanis, who was created a Baron by the King in October, 1893, and his confrères had merited well of the State, and the overthrow of the slave-traders was fully justified by the basis of cruelty and oppression on which their rule rested, though their civilization was far superior to that of the negroes whom they controlled. But the conduct of the struggle was marked by atrocities of the most appalling character on both sides. Neither side was in a temper to give quarter, and the negroes who formed the bulk of the armies were ferocious cannibals, who devoured such prisoners as were taken as well as the bodies of the dead.' The advantage of arms and equipment rested with the Belgians, who had a few cannon and a fair supply of breechloaders, though the number of trained troops never exceeded a few hundreds; the Arabs, whose numbers cannot be stated with

${ }^{1}$ Cf. Johnston, George Grenfell, i. 428, 429. The German natives of Tabora were in 1916 in terror of the cannibalistic traits attributed to the Congo forces (The Times History of the War, xiii. 409). 
any accuracy, were in the main supplied only with cap guns; they were hampered also by failure to accept any common leadership, which exposed them to be reduced in detail by the Belgian troops.

The end of the war, however, was not to see the establishment of peace throughout the territory, as was fondly hoped in Belgium when, in October, 1894, Dhanis returned to his native land to be received as a national hero. For the |misfortunes arising from the military revolts, which were to rage for seven years, the responsibility must be assigned to the author of the murder of Gongo Lutété. His tribesmen had not forgotten the murder, though nominally pacified, and though many of them were retained in the military service of the State. The fatal error was also made of keeping the detachments of Batetelas together, and to their sense of wrong was added the personal injustice of delay in paying their wages, an omission due in the main to difficulties of transport, but none the less inexcusable. On |July 4, 1895, the revolt broke out at Luluabourg, and the mission station there was for a time in danger ; the Lomami district threw off its allegiance, and for the rest of the year and up to January, 1897, the officers of the State were engaged in wearying efforts to deal with the revolted troops and their supporters.

Dhanis himself was to be a peculiar sufferer from this cause. On November 5, 1895, he had left Europe with the rank of Vice-Governor, commissioned by the King to lead the largest force ever collected by the State to take possession of the Lado enclave conceded by the United Kingdom by the treaty of 1894. His great armament was finally ready in October, 1896, and the advance guard entered the Aruwimi forest which Stanley had traversed in his great journey to rescue Emin. The difficulties of the march were appalling, and Leroy, the leader, had not the talents of Stanley; his force reached Dirfi on February 12, 1897, and two days later the Batetelas revolted and shot four of their seven officers. The revolted troops then retraced their steps, brushing aside a vain effort of Dhanis to check their course, and, had they 
been under capable leadership, nothing could have saved the Falls from being sacked at their hands, and the whole authority of the State in the eastern Congo would have been overthrown. Happily they suffered from divided counsels, but the efforts of the State to subdue them occupied its arms continually until the end of 1899 , when the death of Shungufu disheartened the resistance, and by July of 1900 those still in arms had crossed the German boundary. The danger of the conflict was increased by clear proof that the Arabs of Manyema were anxious to use the opportunity to renew the struggle; in May, 1899, an effort to secure cooperation between the Batetelas and the Arabs of Ujiji was discovered and prevented. Even, however, when the Batetelas seemed to have been finally routed, the rebellion suddenly flared out; the plan had been adopted of scattering detachments of Batetelas in places distant from their homes, and a body of these men were in garrison at Shinkakasa, the fort built to protect Boma. On April 17, 1900, they suddenly revolted, and for two days bombarded Boma, happily with no serious results. The failure of other troops to mutiny determined them to flight; cut off, however, before they could escape, eighteen paid the penalty of their treason after condemnation by a Council of War. ${ }^{1}$

The unrest caused by the revolts had its echo in the refusal of the Bujas to keep faith with the State; expeditions against them were necessary in each year from 1898 to 1901, and only in 1905 were they finally pacified, while in 1901 and 1902 meašures were necessary to deal with Portuguese negroes who still sought to ply their forbidden trade.

${ }^{1}$ See Masoin, Histoire, ii. 290-301. 


\section{CHAPTER VIII}

\section{THE ADVANCE TO THE NILE}

VAST as were the burdens imposed on the State by the operations against the slave-traders and its rebellious soldiery, Leopold II declined to permit them to hamper his deliberate purpose of obtaining control of the headwaters of the Nile. In adopting this aim he acted in virtue of his sole responsibility for the government of the Congo, and now reaped the full benefit of his freedom from the control of the Great Powers or even of Belgium, which would certainly have hesitated to support his ambitious projects. At what date the dream of becoming master of the provinces of the south, which were manifestly falling from the hands of Egypt, suggested itself to him is uncertain, but there can be no doubt that he succeeded in convincing Gordon that this was the best mode in. which to combat the anarchy of the south and to overthrow the slave-traders. As we have seen, ${ }^{1}$ Gordon's intention in accepting the King's offer to appoint him to the charge of the Congo expedition in 1884 was to devote himself to attacking the slave-traders in their own head-quarters, and his action is easily explicable when it is remembered that the Association which the King then represented purported to be international and philanthropic in character. In accordance with this plan, after accepting the offer of the British Government to proceed to the Sudan, Gordon wrote from Korosko on February $\mathrm{l}^{2}$ to Lord Cromer (then Sir E. Baring), enclosing a letter to the King in which he spoke of ascending the White Nile with a view to taking possession of the Equatorial provinces and the Bahr el

1 Above, p. 47.

${ }^{2}$ Cromer, Modern Egypt, i. 464 ; cf. Fitzmaurice, Lord Granville, ii. 386 ; Morley, Gladstone, iii. 162. 
Ghazal, and to haiding them over to the King. Lord Cromer disapproved this project and advised Lord Granville that it should be discouraged. On March 9 Gordon repeated by telegraph his suggestion that he should resign his position as an officer of the British Government, and proceed with his steamboats to the southerm provinces, treating them as subject to the King of the Belgians, in reply receiving the instructions of the British Government not on any account to adopt this course. The death of Gordon and the fall of Khartum on January 26, 1885, followed by the evacuation of the Sudan, ${ }^{1}$ left the way open for another effort by the King to secure his position; Stanley offered, as one of the alternative courses open to Emin Pasha, to make him Governor of Equatoria for the King with a salary of 37,000 francs and a grant of 200,000 or 300,000 francs for the cost of administration. ${ }^{2}$ Emin's refusal of this offer in no way discouraged the King, who determined to carry out the proposal by Belgian hands. One possible rival existed, the British East Africa Company, which had profited by the efforts of Stanley during his march to relieve Emin to secure territorial acquisitions for that Company, which had supported generously ${ }^{3}$ the fund from which were defrayed the expenses of the relief expedition. An arrangement with the Company of May 24, 1890, ${ }^{4}$ which foreshadowed the arrangements of the treaty of 1894, at the same time bound the latter not to operate on the left bank of the Nile, thus leaving open to the State the power to reach that river without fear of competition.

Conditions in the Bahr el Ghazal and Equatoria and in the adjoining parts of the Congo territory were indeed such

${ }^{1}$ Announced in the House of Commons by Mr، Gladstone on May 11, 1885 ; cf. Fitzmaurice, op. cit. ii. 402 sq.

2 Masoin, Histoire, ii. 258; Stanley, In Darkest Africa, i. 421 sq.

3 It contributed no less than $£ 10,000$.

${ }^{4}$ Not communicated officially to, or approved by, the British Government, on which therefore it was not binding; C. 7360, p. 1. Cf. Stanley's version of the matter, Autobiography, pp. 413, 414, 418, where he implies that Lord Salisbury had approved his proposal for the agreement, but says nothing as to the Nile. 
as to render intervention an act of humanitarian interest. Lupton had struggled without cessation in the Bahr el Ghazal against the slave-traders whose zaribas covered the land, but his capture by the Mahdists reintroduced the wildest disorder, and Mahdists under Rabah penetrated as far as the country of the Sakaras and defeated the Sultan. The death of the Mahdi and the disputes which followed among his lieutenants enabled the country to regain some measure of order, and in 1890 its chief rulers were Rafai and Jabir, who had served in the Egyptian armies, and the Asandé chief Semio, and Bangasso, ruler of the Sakaras. Such organization as existed was feudal in type, and the influence of Egyptian and Arab civilization made itself felt among even the less important negro rulers. The fate of the district south of Equatoria had been similar : Emin had sent Havash Montasser, his lieutenant, to reduce to order the slave-traders who infested it, and this savage warrior completed the ruin of the country by overthrowing the last vestige of the independence of the Manbettus. The advent of the Mahdi caused further confusion, the negroes taking advantage of the abandonment of the Egyptian posts to wreak revenge for their defeats, while the Arabs of the Aruwimi gradually advanced north by the Nepoko and seized possession of Bomokandi, though their advance was strongly resisted by the negroes.

Preparations for an advance north were made effectively but without serious fighting under M. Janssen's régime in 1889-91: Van Gèle, who in 1886-7 had explored the Ubangi, advanced by the Mbomu, and won over the Sultan Bangasso in 1889, received in the following year the submission of the Yakomas, and in 1891 established communication between Yakoma and Jabir. Baert in 1890-1 advanced by the Mongala and established control of the Ebola and Dua rivers, while in 1889-90 Roget founded the post of Ibembo on the Itimbiri, thus effectively precluding the union of the Arabs of the Aruwimi with the northern slave-traders, and formed an alliance with Jabir, with whom he stationed Milz. The way was thus opened for the great expedition led by Van 
Kerckhoven which, assembled at Leopoldville in September, 1890, reached the flourishing station of Jabir in June, 1891. Its advance thence was steady: on October 21 it dispersed a camp of Arabs at the confluence of the Bomokandi and Uele, obtaining ten tons of ivory as booty, but giving dire cause of offence to the Arabs of the Falls. Bomokandi was reached in December, Nyangara on February 16, 1892, Bitima in April ; treaties were concluded with the native chiefs, and delegates from small Egyptian posts which still existed at Neduda on the Kibali sent messages welcoming the advance. In two months the leader expected to be at Wadelai, but at Lehmin, on August 10, he perished, accidentally shot by his servant. ${ }^{1}$

The work of Van Kerckhoven was effectively pursued by his lieutenants. De la Kéthulle in 1892 received the alliance of Rafai, and the submission of the Abandas and Banjas; in 1894, on the orders of Hanolet, commandant of the Ubangi, he advanced across the Nile watershed and established a post at Katuaka, on the Ada, an affluent of the Bahr el Ghazal. Hanolet himself made a reconnaissance in the Shari valley and entered into secret negotiations with Rabah, who had by that time founded a strong state south of Lake Chad. Milz, who took over command of Van Kerckhoven's expedition, received the submission of the officers of Emin at Wadelai, and occupied that post on October 9, 1892. $\mathrm{He}$ also founded a post at Wando on the Yei, and his successor, Delanghe, established posts at Kiri, Muggi, Laboré, and Dufilé. Donckier and Donceel reached the most northerly point of the advance at Lifi. The dervishes naturally decided to oppose a movement so menacing, and, though Delanghe defeated them at Mundu, it became necessary in August, 1894, to abandon Katuaka, Lifi, and the three Nile stations, but the superiority of Belgian arms inflicted on. December 23 a decisive defeat in a battle on the Egaru.

The Belgian advance naturally evoked the liveliest interest. both in England and in France. The treaty of July 15, 1840, between Great Britain, Austria, Prussia, Russia, and

${ }^{1}$ Masoin, Histoire, ii. 257 sq. 
Turkey, and the.Sultan's Firman of February 13, 1841, definitely assigned the Sudan-then, however, of very restricted area in comparison with its later extension by Egyptian conquests-to Egypt, and no steps had been taken to annul this formal agreement. The claim of Egypt to the southern provinces was recognized in Article I of the Anglo-German convention of July 1, 1890, and in the Anglo-Italian treaty of April 15, 1891, and it was therefore open to the United Kingdom to contend that the Belgian advance had carried them into territories which fell within the sphere of influence of the British Government. The objections of France rested not only on general considerations of the integrity of the Turkish Dominions but on the actual wording of the treaty of April 29, 1887, regarding the boundary between the Congo and French territory. The line under that agreement was to follow the Ubangi up to its intersection with the fourth parallel of north latitude, and the Congo undertook not to exercise any political influence north of that parallel on the right bank of the Ubangi, while France gave a similar undertaking in respect of the left bank of that stream. A further provision provided that in any case ' la frontière septentrionale de l'Etat du Congo ne descendra pas en-dessous du $4^{e}$ parallèle nord, limite qui lui est déjà reconnue par l'article $5^{2}$ de la convention du 5 février 1885.' The Belgian reply was that Article V did not define the limits of the Congo State, but merely indicated the extent within which France was prepared to recognize its neutrality ; that the rights of France were confined to the Ubangi, which ceased at the confluence of the Mbomu and Uele; and that it had occupied legitimately territories which were vacant through the evacuation of the Sudan, and therefore, according to the spirit of the Berlin Act, open to seizure by the first comer, while France had done nothing to make effective a counter-claim.

In point of fact France had done little to develop her claims : in 1889 a small post at Bangi on the fourth parallel

${ }^{1}$ Cf. C. 9054, pp. $17,18$.

${ }^{2}$ Rather the map annexed to the treaty and referred to in the Article. 
marked her furthest penetration, and even in the following years comparatively little was done, though Liotard in 1893 visited Bangasso. Pourparlers between the King and the French Government opened in 1892 with a demand by the State for the frontier of Mbomu and Shinko; in 1893 France decided on an expedition under Monteil, and his lieutenant, Decazes, in March, 1894, came to a provisional agreement with Le Marinel on behalf of the State to maintain the status quo pending decision of the issue by the two governments. The demands of the State were now reduced to Mbomu and the Bahr el Ghazal, but France remained intransigent, and, when a final effort to settle the matter in discussions with M. Hanotaux at Brussels in April failed, ${ }^{1}$ the King definitely authorized his Secretary of State, Baron van Eetvelde, to conclude on May $12^{2}$ the famous treaty with the United Kingdom which for the moment seemed to have secured the completion of the Cape to Cairo route of Cecil Rhodes's ambition. The State definitely recognized the limits of the British sphere of influence as defined in the Anglo-German treaty of July 1, 1890, and in return received a rectification of the frontier in the north-east and a lease of territory. The royal declaration of neutrality ${ }^{3}$ of August 1, 1885, had fixed the eastern boundary of the State at the $30^{\circ} \mathrm{E}$. long., thus excluding from the State the part of the Congo basin lying east of that meridian. It was now agreed, in accordance with the arrangement of 1890 between the Congo and the East Africa Company, that the Congo sphere of influence should be limited north of the German sphere in East Africa by a frontier following the $30^{\circ} \mathrm{E}$. long. up to its intersection by the watershed between the Nile and the Congo, and then along the watershed in a northerly and a north-westerly direction. The territory leased to the King was to commence at a point on Lake Albert immediately south of Mahagi, whence the line was to run to the nearest point of the frontier as newly defined; thereafter it was to run along the watershed of the Congo and the

${ }^{1}$ Masoin, Histoire, ii. 271 sq.

${ }^{2}$ C. 7360.

${ }^{3}$ Hertslet, Map of Africa by Treaty, ii. 552, 553. 
Nile to $25^{\circ}$ E. long., along which it was to run to $10^{\circ} \mathrm{N}$. lat. ; along this parallel it was to be carried to a point north of Fashoda; thence it was to follow the thalweg of the Nile and the west coast of the lake back to Mahagi. This lease was to be personal to the King, but all the territory west of $30^{\circ} \mathrm{E}$. long., together with a strip of ground twenty-five kilomètres broad, extending from the watershed to the lake and including Mahagi, was to remain on lease to his successors so long as the Congo, whether as an Independent State or a Belgian colony, remained under their sovereignty. In his turn the King was to lease to the United Kingdom a strip twenty-five kilomètres wide, extending from the most northerly point of Tanganyika to Lake Albert Edward, which, as the navigation of 'Tanganyika was free under the Berlin Act, would have secured an all-British commercial route from south to north. ${ }^{1}$ It was also agreed that the British Government might construct a telegraph line through the State, but without obtaining any rights of administration, and that in both cases of lease the Power obtaining control of the territory should have no rights political other than those which were in conformity with the agreement.

The conclusion of the agreement was the signal for violent protests from France, Germany, and even Turkey. The interposition of a strip of territory in British hands would obviously be the end of German ambitions for the acquisition of the eastern Congo, and by May $29^{2}$ Belgium had to undertake that the strip leased would not be less than twenty kilomètres from the frontier. Only when this was done did Germany condescend to warn the State that under the treaty of November 8, 1884, she remained responsible for the obligations then undertaken in respect of her territories until England had taken over these obligations with the consent of Germany. The German Government

${ }^{1}$ Rhodes had failed to arrange to use a route through the Congo west of Tanganyika; R. Williams, United Empire, 1917, p. 450.

${ }^{2}$ C. 7390, p. 1. 
then warned on June $11^{1}$ the British Government that the lease projected was in effect an effort to alter the boundary between the Congo and German territory without the consent of Germany; that it aimed at accomplishing an object which Germany had successfully opposed when negotiating the treaty of $1890 ;^{2}$ and that Germany would not consent to the treaty unless its rights and interests were fully satisfied. At the same time pressure was brought to bear on the King of the Belgians, who on June $17^{3}$ asked the British Government to cancel the lease. Lord Kimberley pointed out that the effect of the lease had been misrepresented; that it would in nowise have prevented free communication, as alleged, between German and Belgian territory; and that it could not fairly be represented that at international law Germany had any right to intervene." $\mathrm{He}$ added, however, that the British Government did not wish the matter to be the cause of ill-feeling between Germany and England, and agreed to the modification of the lease, which was carried out by an agreement of June $22,{ }^{5}$ under which the proposed lease was abandoned, while the other terms of the agreement were left intact. The position was somewhat humiliating for the United Kingdom, but the time had not yet arrived when the construction of a through route was of real importance; to quarrel with Germany would be to play the game of France, which menaced the Nile; and it was possible to hope that the King would show his appreciation of the generous terms accorded to him by adopting a definite attitude of friendship to the United Kingdom. Moreover, the treaty settled definitely in a sense satisfactory to England the southern boundary over which Belgian forces had tended to encroach. ${ }^{6}$

Whatever faith may have existed in the prospect of the

1 C. 7390, p. 3.

${ }^{2}$ Cf. J. H. Rose, Development of European Nations, 1870-1900, p. 532.

${ }^{3}$ C. 7390, p. 3.

4 C. 7390, p. 4 ; the German arguments are formally refuted by W. E. Hall, International Law ${ }^{5}$, p. 89, n.
${ }^{5}$ C. 7549.
${ }^{6}$ Above, p. 87 
King's loyalty was destined to be rapidly dispelled. France ${ }^{1}$ had protested immediately against the treaty on the ground that the lease was an alienation of the territory of the State, which required under the French right of pre-emption the consent of France, and that the acquisitions of Leopold would violate the principles of the integrity of the Turkish dominions and the neutrality of the Congo. It was also urged that as England had no effective occupation it had no power to concede territory. An interpellation in the Chamber of Deputies on June 7 was welcomed by M. Hanotaux, who asserted that he had two years before declined to consider similar proposals for the dismemberment of the Sudan. He accused the State of perfidy, and declared that she had broken her relations with France. The Government were supported by the Chamber: 1,800,000 francs were readily voted, of which a million was to be devoted to providing for the reinforcement of posts on the Ubangi and the equipment of gunboats. Monteil's long-delayed departure took place on July 17, and the State was clearly faced with the alternative of yielding or fighting. The King gave way, and on August 14 a treaty was signed under which the State bound itself not to exercise any political influence or effect any political occupation in the Bahr el Ghazal region west of $30^{\circ} \mathrm{E}$. long. or the Nile above $5^{\circ} 30^{\prime} \mathrm{N}$. lat., while in return France conceded a rectification of the frontier of $4^{\circ} \mathrm{N}$. lat. The new line was to start from the junction of the Mbomu and the Ubangi, to follow the Mbomu to its source, thence to proceed to the Nile-Congo watershed, and then to follow the watershed to $30^{\circ} \mathrm{E}$. long. The result was received with satisfaction not only in France, which abandoned Monteil's expedition and the project of placing the Ubangi under full control, con-

1 Masoin, Histoire, ii. 275-8. There was, strictly speaking, something to be said for France, until by the treaty of August 14, 1894, she abandoned her defence of Turkey and accepted gains for herself. The formal French representations (August 7, 1894) were dealt with by Lord Kimberley in a dispatch to Lord Dufferin of August 14, 1894 ; see C. 9054, pp. 13-17. 
tenting herself with taking over the Belgian posts, but also in Belgium, where grave anxiety had been caused at the idea of a rupture between the State and France. The accord established was perfected by the conclusion of the treaty of February 5, $1895,{ }^{1}$ at a time when the transfer of the State to Belgium seemed imminent, under which 'tout échange des territoires congolais avec une Puissance étrangère, toute location desdits territoires en tout ou en partie aux mains d'un État étranger ou d'une Compagnie, on vertu du droit de souveraineté, donnera ouverture au droit de préférence'. A declaration of the same date recognized the right of France to the island of Bamu in Stanley Pool conditionally upon no military establishments being erected thereon. These agreements, however, did not come into force for the time being, as, the proposal of transfer falling through, they were not ratified, but they were renewed on the actual assumption by Belgium of sovereignty over the State. Finally, a fresh declaration of neutrality on December 28, 1894, established the neutralization of the territory within the new boundaries ascribed by the treaties with the United Kingdom and France. ${ }^{2}$

France by her action had left herself the possibility of access to the Nile, but only at the cost of creating a direct issue between herself and the United Kingdom, which made it absolutely plain that an effort to seize the southern provinces would be treated as an unfriendly act. ${ }^{3}$ But France declined to accept this warning: Liotard established himself in 1896 at Tambura in the Bahr el Ghazal, and on July 23 of that year Marchand disembarked at Loango under instructions to reach the Nile. Until March 1, 1897, he was detained at Brazzaville by the necessity of dealing with a revolt in Mayombe, and after that the labour of transporting his flotilla from the waters of the Congo to the Nile proved colossal : over 45,000 men had to be collected, and the unhappy labourers received no pay or considera-

${ }^{1}$ Masoin, Histoire, i. 94.

${ }^{2}$ Hertslet, Map of Africa by Treaty, ii. 557-61.

${ }^{3}$ Sir E. Grey in the House of Commons, March 28, 1895. 
tion. ${ }^{1}$ On July 10, 1898, however, he attained his objective at Fashoda, only to find that the expeditions under Bonchamps and Artomoroff, ${ }^{2}$ a Russian officer, which in February, 1897, had been sent to co-operate with him by way of Abyssinia, had found the obstacles to progress insuperable and had returned to their starting-place. In the meantime the advance of Kitchener, begun on March 14, 1896, had culminated in the great victory of Omdurman on September 2, 1898, and on September 19 the victor reached Fashoda and raised the Egyptian flag in rivalry to the French. Admiration for Marchand's wonderful achievement in France was matched in England by indignation at his effort to steal a march on his rivals, and for once the British Government proved unyielding. On November 11 Marchand had to evacuate the post which he had occupied, and only then would Great Britain negotiate. ${ }^{3}$ The result of these discussions was the Anglo-French Declaration of March 21, 1899, ${ }^{4}$ by which France bound herself not to acquire territory or political influence beyond the NileCongo watershed, thus definitely abandoning the extended boundary which she had exacted from the King in the treaty of August 14, 1894.

During the period of this struggle the King had preserved an ambiguous attitude. He had hastened to secure the withdrawal of the treaty for the cession of the Congo to Belgium as soon as he had succeeded in securing the necessary funds to extricate himself from his immediate difficulties; he was in close touch with the new French President, Félix Faure; Hanolet lent his advice to Hanotaux in regard to the route to be followed by Marchand; and so persistent were the rumours of the existence of a secre treaty that a formal denial was thought necessary in the Belgian Chamber on March 6, 1896..$^{5}$ What is certain is that a great expedition under Baron Dhanis was fitted out

1 Masoin, Histoire, ii. 280, 281.

2 C. Castellani, Marchand l'Africain, pp. 2779, 280.

${ }^{3}$ See C. 9054 and 9055.14 C. 9334.

5 Masoin, op. cit. ii. 282. 
in 1895-6 contemporaneously with the expedition of Marchand, but its prospects were blighted by the military revolt which all but overthrew the State. Chaltin, however, with a smaller force succeeded in reaching Rejaf in February, 1897, and his successor, Hanolet, defeated a desperate Mahdist attack prompted by the desire to obtain his military stores on June 4, 1898. Chaltin, on his return in the next year, fortified the posts of Rejaf, Lado, Kero, Dufilé and Wadelai, and Henri in that and the following year carried out various expeditions on the Nile, returning to Europe via Khartum. ${ }^{1}$

It is possible that the King had visions in dispatching Dhanis's ill-fated expedition of obtaining from England or France some substantial recognition of his services in combating the Mahdists, even if we acquit him of the dream $^{2}$ of being asked to control Egypt as a solution of Anglo-French rivalries. At any rate it is clear that he deemed that the treaty of 1894 had entered into full vigour with the retirement of France from her pretensions under the declaration of.March 21, 1899. The British Government, however, had now other views, which rested inter alia on. the formal recognition, by an exchange of notes contemporaneous with the treaty of 1894, of the rights of Turkey and Egypt in the basin of the Upper Nile. ${ }^{3}$ In point of fact, whatever might have been the case had Dhanis's expedition attained its end, the real victory over the Mahdists belonged to British and Egyptian arms, and the Belgian claim to territorial extension could not be validly pressed. In May, 1899, therefore, a formal notification was made to the King that the rights of Egypt had revived. The King suggested arbitration, but this was refused, and the British Government declined in 1900 to

${ }^{1}$ Masoin, Histoire, ii. 284 sq. On Dhanis's expedition see ibid. ii. 290 sq.

2 Suggested by Masoin, op. cit. ii. 283.

${ }^{3}$ C. 7360 , p. 4. That this was intended seriously was not a contention invented in 1899; it was asserted strongly in the British reply of August 14, 1894, to France on the discussion of the treaty of May 12, 1894 ; C. 9054 , pp. $15,16$. 
permit two Anglo-Belgian companies to operate in the disputed territory. In 1901 it proceeded to occupy the former French posts in the Bahr el Ghazal and in the north of the enclave, and on March 5, 1901, Sir F. Wingate, the Sirdar, had an interview with Hanolet which might have led to an agreement, had the King been willing to accept in full settlement of his claims a perpetual lease of a portion of the enclave bounded by the Yei. The King, however, was foolishly obstinate: troops were collected in the disputed area; Landeghem was sent to occupy Tambura in 1902, and in 1903-5 Lemaire crossed the watershed, advanced beyond the $6^{\circ}$. N. lat., and occupied the territory of the chief Bio. The British replied by occupying rival posts in the Bahr el Ghazal. A modus vivendi of March 9, 1905, left Lemaire in possession of his posts, but the King took the unhappy step of issuing a decree annexing to the State the whole of the Bahr el Ghazal beneath $5^{\circ} \mathrm{N}$. lat. ${ }^{1}$ The act of defiance received the reply it merited: communication between the Belgian posts and Khartum, on which they were dependent for supplies, was forbidden, and the King was compelled to yield. On April 11, 1906, Sir E. Grey announced in the House of Commons that the State would abandon its new posts in the Bahr el Ghazal and retain only the five recognized by the modus vivendi of 1905 , and on May $9^{2}$ the definitive treaty was signed. Under it the lease of 1894, was absolutely cancelled; but for his life the King was permitted to occupy the Lado enclave, defined by the boundaries of $5^{\circ} 30^{\prime} \mathrm{N}$. lat. and the $30^{\circ} \mathrm{E}$. long., the territory to be restored to the Sudan within six months after his death. The boundary between the Congo and the Sudan was also definitely fixed as a line running from the point of intersection of $30^{\circ} \mathrm{E}$. long. with the Congo-Nile watershed along that watershed to the junction of the frontier of the French Congo and the Congo State, ${ }^{3}$

${ }^{1}$ Masoin, op. cit. ii. 287.

${ }^{2}$ Cd. 2920.

3 This boundary (fixed by the treaty of August 14, 1894) had been carried far west by the treaty of March 21, 1899. Germany, both by the 
and the State was assured the continued possession of the strip of territory from the watershed to Lake Albert provided for in the treaty of 1894. An Anglo-Belgian Company was to be granted a concession for the construction of a line from the Congo frontier to the navigable channel of the Nile near Lado, the Egyptian Government guaranteeing 3 per cent. interest on a capital expenditure up to $£ 800,000$, and on the retrocession of the enclave full control passing to the Sudan Government. A port open to general commerce was to be established at the terminus on the Nile, and on the determination of the lease a Belgian or Congolese firm was to be permitted the possession of a depôt and quays, remaining, however, entirely under Sudanese laws. Equal rights of navigation with British or Egyptian ships on the Upper Nile were conceded to Belgian or Congolese vessels. The State in return bound itself not to erect works which would diminish the flow of the river Semliki into Lake Albert without the consent of the Sudanese Government, and both parties agreed to refer to The Hague any future boundary disputes, not arising out of the lease of 1894. The surrender of the King was complete, and by July, 1908, the last Belgian posts had been withdrawn from the area beyond the enclave as now defined.

Thus ended the great enterprise which the King had carried on for fifteen years at a cost of not less than $2,000,000$ francs annually. The net gain to the State was nil, save in so far as his efforts may have succeeded in obtaining from Françe a more generous boundary than she would else have conceded. ${ }^{1}$ On the other hand, he had undoubtedly helped to prevent the spread of Mahdism and could claim thus to have served a useful purpose. Unhappily the quality of the civilization which had been introduced was of a low order. In reporting on January 21,

treaty of 1890 and that of 1893 (Article IV), had recognized the British claim to Darfur, Kordofan, and the Bahr el Ghazal.

${ }^{1}$ Cf. Masoin, Histoire, ii. 288, 289. 
$1903,{ }^{1}$ on his visit to the Sudan, Lord Cromer noted that on the Belgian bank of the Nile not a village or human being was to be seen, while the Anglo-Egyptian bank bore every sign of a contented and prosperous population. 'The reason of all this', he wrote, 'is obvious enough. The Belgians are disliked. The people fly from them; and it is no wonder that they should do so, for I am informed that the soldiers are allowed full liberty to plunder, and that payments are rarely made for supplies.' No Belgian, he reported, could move outside the settlements without a strong guard, and the nearest native village was seven hours' journey from the post of Lado, which the natives carefully shunned.

A more abiding result of the northern campaigns was the definite occupation of the Ubangi, which formed a necessary basis for the Belgian advance. Chaltin in 1895-6 secured the Uele by the erection of strong posts at Jabir, Neré, Nyangara, and Dungu, which overawed the malcontents in league with the Mahdists. In 1898 a revolt of the chief Bokoyo was successfully repressed; but from 1900 to 1902 operations of a troublesome character were required against the Asandés and Ababuas, and a final revolt of the Sultan Jabir in 1905 ended in his capture and death. ${ }^{2}$

${ }^{1}$ Cd. 1933, p. 2 ; cf. Masoin, Histoire, ii. 288, 289.

${ }^{2}$ Cf. Johnston, George Grenfell, i. 435, n. 1, where the action of the State is regarded as harsh in view of Jabir's former ready aid in the period of the weakness of the State. 


\section{CHAPTER IX}

\section{THE MALADMINISTRATION OF THE STATE}

THE preoccupation of Leopold II with plans of aggrandizement prevented him from making use of his unparalleled opportunity to develop an effective civil administration for the new State, nor had he the good fortune at any time to have the services of a genius with powers of civil organization. The sole power in the territory rested in his hands and the temptation was inevitable, in the case of a sovereign of great energy and few other royal duties, to seek to maintain in his own control the supervision of the whole business of the State. The result was that for good or bad the government remained in his control, and the various officials who served under him were nothing but the more or less effective instruments of his personal. will. ${ }^{1}$

The form of government was necessarily unique, as the head of the State was precluded from residence in his territory, and was not prepared to assign any real independence to the local authorities. The central government was situated at Brussels, organized in the departments of Foreign Affairs and Justice, the Interior, and Finance, each under an Administrator-General, the first holders of the offices being Van Eetvelde, Colonel Strauch, and Van Neuss. ${ }^{2}$ In September, 1891, the title of these officers was altered to the more accurate one of Secretaries of State, and on September 1, 1894, a further centralization of the régime was completed by the appointment of Van Eetvelde to be

${ }^{1}$ F. Cattier, Droit et administration de l'État indépendant du Congo, pp. 134, 135.

2 Masoin, Histoire, i. 47. They were appointed on May 6, 1885. Legally the State treated itself as coming into being on July 1, 1885. 
the sole Secretary of State, having under him the three heads of the administrative departments, now designated Secretaries-General, and a new officer, the TreasurerGeneral. This arrangement was modified in 1901, when Baron van Eetvelde resigned the office of Secretary of State: the power hitherto in his hands was transferred to the Secretaries-General acting together, and the King's acts continued to be countersealed in the name of the Secretary of State, a curious fiction, possibly affected because of its apparent concinnity with the acts of the King as constitutional monarch of the Belgians.

The King possessed supreme legislative and executive authority, and, somewhat inconveniently, no distinction was observed between his mandates in these two aspects, his legislative acts being styled décrets equally with his administrative regulations (arrêtés). The power to issue regulations was freely delegated both to the Secretary of State and the Governor-General, but the right to issue laws was only permitted to the latter, and then for temporary and special purposes, such enactments being styled ordonnances. The King reserved to himself the power of pardon, but did not exercise any other judicial functions. The Conseil superieur of the Congo, with its seat at Brussels, acted as a court of second appeal in important cases of a civil character, as a court of appeal in penal matters with regard to certain classes of offenders, and as a court of cassation. It did not pronounce penal sentences, as, being situated in a foreign state, it had no power to carry out its decrees in such cases.

The local administration was simple, and took definite shape in 1887, when a decree of April 16 conferred the title of Governor-General on the chief official, hitherto styled Administrator-General. To him appertained the exercise of the executive power in the Congo, with occasionally authority to legislate. In his labours he had the aid of a Vice-Governor-General, who was of value as representing him in the more distant parts of the territory while he stayed at the capital Boma, a State-Inspector, and four 
Directors, the heads of the departments of the Government. ${ }^{1}$ A decree of ${ }^{\circ}$ August 1, 1888, divided the country into eleven districts, a number increased in 1890 to twelve and in 1895 to fifteen. ${ }^{2}$ At the head of each was a Commissioner representing the Governor-General, and from 1892 onwards the plan was adopted of placing at the capitals of the greater chiefs, whose relation to the State was rather one of alliance than subjection, officers styled Residents. This plan, however, was essentially temporary; disappearing with the progressive reduction of the power of the chiefs, and gradually the districts were divided up into zones, thence into secteurs, which again were subdivided into postes with a hierarchy of officers all dependent on the Commissioner, an arrangement ideally contrived to multiply correspondence and to paralyse effective action. The Governor-General was authorized by a decree of October 6,189 ], to accord investiture to native chiefs, but this preliminary to effective organization of the tribes remained without result for twenty-five years, ${ }^{3}$ and the native tribes were left at the mercy of a system which imposed upon them at the pleasure of the local officer any ex-soldier or other person who was deemed likely to be obedient to the orders of the State.

The judicial system was simple and imperfect. Until 1906 there was but one court in the whole territory competent to deal with civil and commercial cases in which a non-native was party, the Tribunal of First Instance at Boma, consisting of one judge only. In criminal matters until 1889 jurisdiction over non-natives was vested solely in the court situated at Banana, and later at Boma. In that year, however, its authority was confined to the Lower Congo, and jurisdiction in the Upper Congo was conferred on territorial tribunals consisting of one judge, a civilian, or beyond their sphere of activity to councils of war, also composed of a single judge selected by the Governor-

- ${ }^{1}$ A consultative Council existed (July 30, 1886), but rarely, if ever, met.

${ }^{2}$ Later reduced to twelve.

${ }^{3}$ Only 450 chiefs had been recognized by 1906 . 
General; two assessors were added if the charge was a capital one, and an appeal lay to the court at Boma. In 1894-5 the law was modified to abolish the requirement of assessors. The right of condemning a European to death was reserved to the court at Boma, and the institution of: territorial tribunals was made general, leaving, save in certain cases, councils of war capable only of dealing with soldiers. But the Government still maintained the rule of appointing administrative officers to judicial appointments, and in the absence of security of tenure it was impossible to regard these officers as sufficiently independent of the executive from whose ranks they were recruited and on whose goodwill their future might depend, while the paucity of courts was the cause of great hardship and inconvenience.

The position of the natives in regard to judicial matters was still worse than that of Europeans. In civil matters they were in theory free to carry their complaints to theirv own chief or to the European courts, ${ }^{1}$ but the absence of any local system of civil jurisdiction rendered the permission to have resort to the latter jurisdiction a mere farce. In criminal matters ${ }^{2}$ the European tribunals were in theory the proper authorities to deal with native cases, but it was legitimate to leave the accused to be dealt with by his chief: in practice the native was subject to ill treatment by his chief, often an outsider imposed on the tribe, or was at the mercy of the officer in charge of the poste, who, though without legal right, assumed the power of imprisoning or flogging him at pleasure. Redress against the acts of the State or its officers acting within the bounds of the orders of the State could not be obtained from the law courts, and it was extremely difficult to secure punishment of criminal actions by State officials of any grade.

The military forces of the State were at first recruited from the surrounding colonies, and efforts were even made

${ }^{1}$ Decrees of Jan. 11, 1891; June 3, 1906 (Articles 1 and 6); for the competence of the Native Courts see Ordinance of May 14, 1886, Article 4.

2 Penal Code, Article 84. 
to induce Zulus to serve. ${ }^{1}$ In 1885 the first attempt to secure local recruits was made among the Bangalas, and by 1889 fully one hundred had been enrolled. The expense of voluntary service, however, proved too great, and a decree of July 30, 1891, created a system of compulsion for men between 15 and 30, the numbers required from each district being determined by the Governor-General and raised by the Commissioner in accord with the native chiefs. The army thus rapidly grew in numbers, reaching 16,000 men in the active force, the schools of instruction, and reserve, under 358 European officers. The term of service, originally fixed at five years, was extended in 1900 to seven with five in the reserve, and the pay of the active soldier was fixed at twenty-one centimes a day, a third being held back until the period of discharge. Polygamy was discouraged, but the soldiers were encouraged to have their wives and children with them. The recruits from the eastern provinces proved in the long run too dangerous for the safety of the State, and recruiting there was suspended in view of the revolts which troubled the period from 1895 onwards, but the soldiers on the whole showed excellent military qualities, while on their return to civil life many of them brought back to their villages higher standards of life and industry. ${ }^{2}$ The recruits were trained in the schools at Kinshasa, the Equator, and Zambe, while accountants received instruction at Boma, and technical training was given to a corps of armourers. ${ }^{3}$

The cost of this military force and of the incessant expeditions pressed with ever-increasing stringency on the resources of the State, and it was the need of fresh sources of income coupled with the helplessness of the natives that $\checkmark V$ produced the evils which from 1891 disfigured the Congo régime. In its early years the State had acted in commercial matters in entire conformity with the spirit of the Berlin Act: it encouraged the presence of traders in the Upper Congo, and made no claim to a monopoly of ivory or rubber, the chief commercial exports. In its land policy, 1 Masoin, Histoire, i. 55 sq.

${ }^{2}$ Cf. Johnston, George Grenfell, i.494-6. ${ }^{3}$ Created by a circular of August 5, 1905. 
the fundamental question for an African Government, it had at the outset adopted two principles, both justifiable in the abstract. In the first place it asserted the claim of the State to all vacant lands, and in the second the right of the natives to continue to enjoy the lands which they occupied, their dispossession being expressly forbidden by an Ordinance of July 1, 1885. The position assigned to the natives was made more precise by a decree of September 14, 1886, which forbade the registration of title to land acquired from natives, whether absolutely or on lease, without the assent of the Governor-General. The sense of the term 'occupied' as applied in this case was, according to instructions stated to have been issued in 1886 but not made public until twenty years afterwards and certainly never acted upon, ${ }^{1}$ wide enough to include not only land dwelt on or cultivated but land exploited in any manner. As early as May, 1890, Grenfell ${ }^{2}$ noted that the State agents had begun, under the influence of a commission paid on ivory secured by them, to seek to hamper private transactions : the agent of the State at Bumpa on the northern Congo was reported to fire on canoes carrying ivory west and to have prevented canoes proceeding eastwards from Bopoto to purchase, ivory. In the following year the matter became prominent through a dispute between the Société Belge du Haut Congo and the Government: the former objected to the State taking any part in the traffic in ivory, while Coquilhat, on the contrary, suggested that the systematic exploitation of the property of the State would solve the ever-increasing difficulty of meeting the burden of its administration. ${ }^{3}$ The matter ${ }^{4}$ was. decided by a decree of September 21, 1891, which significantly never appeared in the Bulletin Officiel, and which enjoined upon the Commissioners of the Ubangi, Uele, and Aruwimi districts the duty of securing for the State the produce of the domain, especially ivory and rubber. This was followed up by three circulars in 1892

${ }^{1}$ Lannoy, L'organisation coloniale belge, p. 138.

2 Johnston, op. cit. i. 445.

${ }^{3}$ Masoin, Histoire, i. 87 sq.

${ }^{4}$ Cd. 4466, pp. 14-26. 
which forbade the natives to sell the products of the domain, prohibited their purchase by traders, and closed the country above Yakoma to trade. The State justified its action by the opinion of eminent legal authorities, including Professor Westlake and de Martens : it contended that it was merely taking legitimate steps to develop its private property, and that the Berlin Act had no application to its action. The measure, however, was warmly opposed by many of those who had been the most steadfast supporters of the King in his policy : the Governor-General, Janssen, took the honourable step of resignation, and among others, Banning, Beernaert, Van Neuss, and Wauters denounced the royal policy. The companies affected also protested loudly, and the King made some concessions. A decree of October 30, 1892 , left open for competition certain districts, especially on the Kasai, but reserved as domaine privé in the narrower sense of the term about half the area of the State, including nearly all the territory above the equator, and provisionally closed the Katanga on the ground that the State was not yet in a position to guarantee the safety of those seeking to exploit it. In point of fact the agreement of March 12, 1891, with the Katanga Company had created the whole territory an undivided property of the State and the Company, and had deprived the State of the power to make grants. ${ }^{1}$

The mode of development chosen by the King, both for the domaine privé and for the lands nominally open, was mainly through concessionary companies, to two of which, the Compagnie anversoise du Commerce au Congo and the Abir, he had already on August 2, 1892, made large grants. On March $9,1896,{ }^{2}$ he created from out of the nominally open lands the Domaine de la Couronne; to this foundation were attributed 250,000 kilometres in the centre of the State, the revenues of which were to form a sort of Civil List and to afford the means for carrying out the grandiose conceptions which he had formed for the embellishment of Belgium by public buildings, though this plan admittedly had, save in the most remote degree, no interest for the Congo itself. In

1 Above, p. 84.

${ }^{2}$ Masoin, Histoire, ii. 208 sq. 
1897 a considerable number of companies began operations in the Kasai, but their competition proved disastrous, and at the end of 1901 the King succeeded in inducing them to amalgamate and to enter into partnership with the State. The revenue rose rapidly from five and a half millions in 1893 to twenty-six in 1900 and to nearly thirty-one in 1901, and from that year, when the control over the borrowing of the State possessed by Belgium in virtue of the agreement of 1890 ceased, the King used the power to raise loans to secure a dominant influence in the companies which exploited the State. ${ }^{1}$

It was, of course, essential to procure labour for the exploitation of the domain, and the State frankly set itself to secure that labour from the native either by inducing him to work by remuneration, or by imposing such taxation as would compel work. The taxation imposed in 1892 represented in money from six to twenty-four francs annually, but in the absence of either money in the hands of the natives or the means of earning it, owing to the reservation by the State of rubber and ivory, the native had to pay it in labour. Each chief of a post and head of factory was authorized to collect the tax, and to prescribe its amount and the remuneration to be assigned to it, the latter device being intended to secure more willing work from the natives. The activity of the officials was stimulated by payment by commission, ${ }^{2}$ and the work of the natives was carried out under the supervision of armed sentinels. The result was inevitable: the sentinels acted as petty tyrants-in seven months in the Abir concession alone 142 of them were killed or wounded in reprisals by the natives, while the remuneration paid was often nugatory and the amount of produce exacted as a result of the work imposed varied from nine kilograms of rubber in the Mongala district to as low as two elsewhere. The State recognized in some measure the

${ }^{1}$ For a list and a map see Johnston, George Grenfull, i. 476-80.

2 This was denied by the State, but admitted by Masoin, Histoire, i. 94, 95, and see Cattier, Droit et administration de l'État indépendant du Congo, pp. 243 sq. 
danger, and endeavoured by various devices to reduce the temptation of their agents to misuse their powers, but with little success. In 1903 the tax was fixed definitely and uniformly at forty hours' labour, but the necessary measures to make the rule effective were not taken, and in many places days were spent by the natives in going to and from the forests where they had to collect the rubber. In other cases, where the taxation was imposed in the form of rev quiring supplies of products grown by the natives in the lands recognized as theirs, the abuses took the form of valuing the produce at an absurdly low figure, and compelling the natives to bring in their tribute from long distances involving great suffering and fatigue. Failure on the part of the natives to comply with demands was punished by the arrest of the chiefs, the taking as hestages of the women, imprisonment, flogging, or other still more disgraceful methods of barbarism. On July 1, 1904, the State itself found it necessary to take away from the companies the right of exploitation in Mongala, so shamefully had the agents abused their powers.

It was obvious that there were great dangers in a system $h$ which confounded the official of the State with a commercial agent, and imposed on the same man, often young, badly paid, ${ }^{1}$ in a trying climate, the inconsistent duties of applying the laws, rendering justice, protecting the native, and obtaining from him the maximum output. The complete conversion of the State into a great commercial concern was formally signified in the fact that no effort was made to maintain the essential distinction which should have existed between products purchased from the native and those received in payment of taxations : all the receipts from the domain appeared in the budget under the style of " products of the domain, tributes and imposts paid in kind by the natives'. The policy of the State was not a new one: it was closely similar to that of Holland in Java from 1830 to 1870 , but Holland had the excuse that, when she adopted the

${ }^{1}$ From $£ 80$ to $£ 200$ a year; cf. Johnston, George Grenfell, j. 448, 478. One concessionary company gave $£ 40$ to $£ 60$ a year; ibid. i. 461 , n. 1. 
system, humanitarian ideals were far less advanced than in 1890, and above all, the territory had been entrusted to the King for no other reason than that he was believed to be animated by the highest motives of benevolence and humanity.

Rumours that the state of the Congo was far from satisfactory were already in circulation in 1895, when a painful episode brought the British Government into strained relations with the State. In January, 1895, in connexion with the measures taken to suppress the slave-traders the Belgian officer, Lothaire, summarily executed a British subject, C. Stokes, ${ }^{1}$ on the charge of supplying arms and ammunition to the Arabs. The action was rendered the more inexcusable because Stokes had come to Lothaire's camp in good faith on what seemed to be a courteous invitation, and would doubtless have been able to resist arrest successfully, had he had any reason to suspect the fate prepared for him. Stokes had been employed by the German Government in East Africa, and in his expedition were natives from German territory, who were detained illegally after the execution of their master and the confiscation of his effects, with the result that some of them died. It was the German Government which brought to notice the incident, and the support of that Government ${ }^{2}$ resulted in the full investigation of the episode by the State. It was admitted ${ }^{3}$ that the trial of Stokes had not been in accordance with the law of December 22, 1888, in that there had been no Registrar present at the trial, and that Stokes had not been permitted to appeal, as he was entitled to do, to the court at Boma, while the confiscation of his property was not defended, and the detention of his servants was admitted to be illegal. The State accordingly admitted liability for the death of Stokes, paid 150,000 francs compensation to his mother and daughter, and restored the value of the ivory taken from him, while Germany received 100,000 francs in respect of the unjust treatment of his servants. Moreover, it was

${ }^{1}$ C. 8276.

${ }^{2}$ Ibid. pp. 39 sq.

${ }^{3}$ Ibid. pp. 52, 53. 
agreed to bring Lothaire to trial for his illegal action. The trial took place at Boma on April 24-7, 1896, ${ }^{1}$ with the result that he was acquitted, and an appeal to the Conseil supérieur at Brussels confirmed this result, an unfavourable impression being caused by the fact that the Ministère public adopted the remarkable course of asking the Conseil to confirm the acquittal of the court below. In neither court were the proceedings conducted with much show of judicial impartiality, and this fact no less than the murder caused much feeling in England, where stress was laid on the fact that, had the British Government exercised its right under the treaty of 1884, Lothaire would not have been able to bring Stokes to trial. ${ }^{2}$ Fortunately for the State, there was reason to suspect that Stokes had in fact been of service to the Arabs, ${ }^{3}$ and the State, by issuing a decree of October $30,1895,{ }^{4}$ which forbade any but the court at Boma sentencing a European to death, gave assurances that such a judicial error would not be repeated. In the following year a further proof of the good faith of the State appeared to be given by the decision of the King to appoint from the missionaries in the Congo, by a decree of September 18, 1896, a Commission to protect the rights of the natives, with George Grenfell as Secretary. ${ }^{5}$ But as Grenfell recorded in November, $1896,{ }^{6}$ two months after the creation of this body, the Commission was powerless to effect anything. Its members were separated in some cases by as much as a thousand miles: the nearest to the regions under the concessionary régime at that time was not closer than 200 miles, and no provision was made for the travelling expenses of the members nor for giving them the right of taking evidence; and it is difficult to acquit the King of a deliberate attempt thus to disarm suspicion.

In 1898 there was issued an authoritative report by

1 C. 8276 , pp. 121 sq.

${ }^{2}$ Ibid. pp. 164 sq.

3 Johnston, George Grenfell, i. 429, 430.

4 C. 8276, p. 176.

${ }^{5}$ Cd. 1754.

${ }^{6}$ Johnston, op. cit. i. 440. 
Mr. Consul Pickersgill ${ }^{1}$ on the state of the Congo, based on a journey which he made in the latter part of 1896, before the concession system had had time to take full effect. In this carefully balanced review Mr. Pickersgill laid stress on the great boon which the administration had conferred on the State by its adoption of prohibition of the liquor traffic in the Upper Congo; on the cessation of intertribal wars and the defeat of the slave-traders; and on the diminution of cannibalism, which had shortly before been a normal practice. He noted, however, that the State retained in compulsory employment for a period of seven years-as contrasted with five years in Angola-the slaves whom it liberated, in lieu of paying them wages as free men, and that, while it was training the natives to work, it had resorted, in over-haste to make progress, to the method of forced labour for transport, for building houses and making plantations, and for collecting produce. The system of supervision of work by sentries he condemned as open to much abuse, and reported that the GovernorGeneral, Wahis, had at one time contemplated its abolition. Among the European population of traders and missionaries he heard complaints of the Governmental ivory and rubber monopoly; of the over-centralization of government and red-tape ; and, above all, of the harassing taxation of every kind, which, as the English and American missionaries remarked, left 'nothing free in the Independent ${ }^{2}$ State except fevers', while a Belgian Father declared, 'The Government taxes even the civilization we bring'. Mr. Pickersgill recorded also the great decline in the volume of trade and profits derived by the great Dutch trading-house which once dominated the Congo trade, and by the British firm which formerly derived a substantial revenue; and the force of this view was demonstrated by the figures of the Congo trade for 1897, which were issued simultaneously with Mr.Pickersgill's report. The exports to Holland, which in 1888 had been valued at $4,943,177$, had fallen to $2,348,097$ francs. The British share of the exports had fallen from

$$
1 \text { C. 8649-30. }
$$$$
2 \text { sic: read Free. }
$$ 
937,027 to 339,840 francs. On the other hand, the share of Belgium had risen from 249,884 to no less than 12,882,901 francs, made up principally of rubber, ivory, palm oil, and palm kernels. In the case of the import trade the position of Belgium was no less remarkable: from a total of $4,422,661$ francs in 1893 , it had risen in 1897 to $16,272,028$, while British trade had remained practically stationary at 2,593,247 francs in 1897 as against 2,591,237 in 1893. These figures were sufficient to prove that, whatever the intention of the Berlin Act, it had not succeeded in securing anything like equality of commercial opportunity, for British trade could not have suffered more had the Congo been a Belgian colony. ${ }^{1}$

There was, however, a general willingness in the United Kingdom to refrain from criticism of the State, whose difficulties were recognized, though the British Government found it necessary in 1896 to forbid the enlistment of labourers in British territories for service in the Congo; and on April 2, 1897, Sir Charles Dilke commented with just severity in the House of Commons on the deplorable excesses committed by the auxiliaries of the Congo forces in the slave-trade campaign. The period from 1896 to 1902, however, was marked by the most grave misgovernment, and in 1901 the death of Rabinek, after condemnation for trading in the Katanga on the faith of the Berlin Act, drew fresh attention to the state of the territory. ${ }^{2}$ Moreover, appalling accounts of the treatment of the natives by the concessionary companies, and the State forces acting under them, were sent home by the members of the Livingstone Inland Mission with its head-quarters at Balolo in the Domaine de la Couronne, the American Presbyterian Mission with stations on the Kasai and the Lulua, and the American Baptist missionary Sjöblom, and their allegations were supported by ex-officials of the State, whose positive testimony could not be disposed of merely by accusing them of acting under animus to their former employers. The Aborigines Protection Society investigated

$$
{ }^{1} \text { C. 8648-140. }
$$$$
{ }^{2} \text { Above, p. } 89 .
$$ 
the question, and Mr. H. R. Fox Bourne published a record of the results in Civilization in Congoland, a Story of International Wrongdoing, in 1903 . Mr. E. D. Morel, formerly employed in the shipping office of Messrs. Elder, Dempster \& Co., in which capacity he had had special facilities for acquiring an accurate knowledge of the state of affairs in the Congo, took up the case against the State with much vigour, ${ }^{1}$ securing in 1904 the founding of the Congo Reform Association. Efforts were made to excite sympathy with the natives in Europe and America. In Belgium the Socialist leader and patriot Vandervelde lent his aid, along with Lorand, Cattier, ${ }^{2}$ Vermeersch, ${ }^{3}$ and others, including the newspapers Le Patriote and La Réforme. Italy was moved to discourage emigration to the Congo and eventually, in 1905, to forbid the employment of her officers in the Congolese service. ${ }^{4}$ Some measure of support was found among German merchants, who resented the Belgian monopoly of trade, and in the United States the Senate, at the instance of Senator Lodge, on December 11, 1906, definitely espoused the cause of the natives. In France opinion was divided, ${ }^{5}$ but the Government had just decided on the unhappy imitation of Belgian policy, which for a time nearly ruined the French Congo, and no support could therefore be expected from official circles. The State, for its part, was extremely active in its own defence. On its behalf there was founded in August, 1903, the Fédération pour la défense des intérêts belges à l'étranger, and in July there began the publication of La Vérité sur le Congo by a bureau which poured forth, regardless of cost, a copious stream of eulogies of the King, of the State, of its administration, and its officers, and of abuse of the missionaries who denounced it and of the merchants who supported them, accusing them of political jealousy, commercial motives, and hatred of the

- 1 In King Leopold's Rule and various other works.

2 Droit et administration de l'État indépendant du Congo (1898), and La Situation de l'État indépendant du Congo (1905).

3 Question Congolaise (1905).

4 Masoin, Histoire, i. 156.

5 P. Mille, Le Congo Léopoldien (1905). 
Roman Catholic Church. It was natural that the State should receive wide support in Belgium, which had profited so largely at the expense of the State, and which was naturally loath to believe that Belgians could be guilty of the crimes of which they were accused, not realizing how much was due to the faults of the system under which they worked, and the moral deterioration caused by the climate. Stress was also laid on the fact that the Roman Catholic missionaries took little part. in the accusations, an argument which ignored the fact that the missionaries were under superior control; that the King was on excellent terms with the Church; and that, as Belgians, the priests were naturally unwilling to accuse their countrymen of crimes which might afford a ground for the interference of Europe in the future of the State. Moreover, the vast area of the territory afforded specimens of every kind of administration; the Lower Congo was admittedly well governed on the whole, and many of those who defended the State, like Lord Mountmorres ${ }^{1}$ - though in his case with reserves of importance-had not had opportunities of inspecting the scenes where the worst crimes were committed. The Roman Catholic hierarchy, even in America, ${ }^{2}$ unhappily permitted itself to be led to accept the view that the interests of the faith demanded the denial of the wrongs of the Congo, and thus quite unnecessarily religious animosities were imported into the discussion.

In England the Government were at last compelled, in 1903 , to take action by the force of public opinion expressed in the resolution of the London Chamber of Commerce, that the régime of trade in the Congo was a violation of the Berlin Act, and by resolutions from such bodies as the Free Church Council and the Baptist Union, denouncing the treatment of natives by the State: The Labour party on May 4 had the opportunity of hearing Vandervelde's views, and a great meeting on May 6 focused public

${ }^{1}$ The Congo Independent State (1905). Cf. Johnston, George Grenfell, i. 484, 485.

2 e.g. Cardinal Gibbons.in 1904; Masoin, Histoire, i. 150. 
opinion on the issue, which was presented by Mr. H. Samuel to the House of Commons on May 20. The Government then accepted a motion urging them to put themselves into communication with the other Powers signatory of the Berlin Act, in order to find a remedy for the abuses. In accordance with this resolution the Secretary of State addressed on August 8, 1903, ${ }^{1}$ a dispatch to the other signatory Powers. Attention was called to the abuses alleged to exist in the Congo-to the system of forced labour, to the failure to effect anything for the moral welfare of the natives, to the fact that the natives avoided contact with Belgian posts, and to the neglect by the State of the commercial clauses of the Berlin Act, which, it was suggested, might well form the subject of reference to the Hague Tribunal. The reply of the State, dated September 17, ${ }^{2}$ was violent: it endeavoured to justify all its acts by British parallels, adduced citations of Mr. Chamberlain's views on native taxation as applied in Sierra Leone, drew a comparison between the movements of the natives in the Upper Nile and in Belgian territory, and maintained, on the strength of utterances of Lord Cranbourne, that it had furthered native interests. It absolutely denied the right of the Hague Tribunal to deal with any question of an internal character, but maintained that in any case all the signatory Powers must be parties to any arbitration, and suggested that the question of the Bahr el Ghazal, still under dispute, should properly be referred to that tribunal. The response of the Powers to the British note was disappointing, the United States and Italy alone showing interest, for the more emphatic support of 'Turkey was at the time morally valueless. On the other hand, precise facts on which to base a reasoned opinion of the real nature of the administration of the Congo were furnished in abundance by the report, dated December $11,^{3}$ of Mr. R. Casement, who in June had been commissioned to investigate conditions in the Congo. This report showed that the

${ }^{1} \mathrm{Cd} .1809$.

${ }^{2}$ Cd. 1933, pp. 2-21.

3 lbid. pp. 21-82. 
depopulation of the Congo, which was noted, was due to the system of oppression in force, and that the natives in many districts were living under a system of forced labour, exacted from them by inhuman methods involving murder and mutilation, deprived of any opportunity to raise themselves in the scale of civilization, and reduced to serfdom. Mr. Casement's report was communicated on February 11, $1904,{ }^{1}$ to the State, in a note in which it was pointed out that the new evidence afforded ample justification for the statements made in the dispatch of August 8, 1903. The State replied on March $12,{ }^{2}$ controverting in detail the statements of the report, but promising the carrying out of a searching inquiry into the allegations made, and asking for the full text of the report, including the names of natives and places suppressed in the published version in the interests of the witnesses, who would else have been exposed to maltreatment by the officials of the Companies and the State. On June 9, a debate in the House of Commons on Mr. Casement's report, evoked strong expressions of hostility from Mr. Samuel, Lord E. Fitzmaurice, and Sir C. Dilke, though opinion was divided as to whether an International Conference or the aid of America would be the most effective manner of dealing with the question. The British Government for its part pressed the State Government to secure that the Commission of Inquiry should be so constituted as to command public confidence, and that a British representative should be allowed to be present at its sessions. The latter request was conceded too late to enable the privilege to be availed of until nearly the end of the proceedings, and the former was evaded. The Commission was composed of M. E. Janssens, Advocate General in the Court of Appeal of Belgium; Baron Nisco, President ad interim of the Appeal Court at Boma; and Dr. E. de Schumacher, Councillor of State and head of the department of Justice of Lucerne, a decision which naturally was anything but satisfactory to British public opinion. ${ }^{3}$ The Commission arrived at

1 Ibid. p. 82.

${ }^{2}$ Cd. 2097, pp. 1-40.

${ }^{3}$ Cd. 2333. 
Boma on October 5, and after proceeding to Stanleyville returned to Boma on February 13, 1905, having given to its investigations a period ${ }^{1}$ far too short in a country of so great distances and difficulties of travel for any complete investigation. A long delay followed: the Congo Reform/ Association pressed for an international investigation; the summoning of an International Conference to recast the Berlin Act; the submission of the commercial question to the Hague; and the appointment of British consuls to exercise jurisdiction under the treaty of 1884 , a demand to which Sir C. Dilke lent his authority on August 3 in the House of Commons. The long-expected report was signed on August 31, but not published until November 4, when the reason for delay became obvious. ${ }^{2}$ The full text of Casement's report had been communicated to the Commission under due precautions, to secure the witnesses from molestation; but the State declined absolutely to publish the evidence on which the Commission's report rested, and its tenor must have been even more unfavourable to the State than the actual report, which derived the more weight in that it was practically a Belgian product.

The report condemned the land policy of the State, as monopolizing the entire fruits of the soil and hampering the evolution of native existence. While accepting the principle of forced labour as justifiable, ${ }^{3}$ it denounced the modes of enforcing it actually adopted, often in defiance of the letter of the law. It condemned outright the system of using native sentinels. It disapproved in the most strong terms the system of native military expeditions, often ordered by concessionary companies. It condemned the concession system and recommended the restoration of free trade. It censured the system of State education in colonies, and, while approving the principles of the labour

1 November 5 to January 26, the rest of the time being occupied in travel.

2 Cd. 3002.

3 For a defence of the doctrine that compulsory work is good for natives, see citations in Masoin, Histoire, i. 91-3. 
legislation, it admitted that in the Upper Congo they were not executed. It dwelt on the unsatisfactory character of the administration of justice, and on the absence of any legal control over the actions of the administrative authorities. ${ }^{1}$ The King was too astute to let the matter rest there : he named a Commission of fourteen members to examine the position and to formulate projects for remedying the abuses revealed. Further delays ensued: in February and March M. Vandervelde secured a full and important discussion in the Belgian Chamber, which expressed on March 2, 1906, its confidence in the programme of reforms to be announced by the Commission, and its determination to resume the consideration of the draft law on Colonial organization which had been laid aside since August, 1901. In May in the House of Commons the Government were pressed to ask the State to accelerate the process of reform, and on June 3 the King issued an imposing series of reform decrees. $^{2}$ The Native Lands decree asserted the right of the natives to lands cultivated, inhabited, or exploited by them, authorized the Governor-General to allot to each village three times as much land as they actually occupied or even more, and recognized the natives' rights to cut wood, fish, and hunt on other land, subject to the existing laws regarding the preservation of forests and game, including elephants. ${ }^{3}$ The native taxation of from 6 to 24 francs a head was retained and made applicable to women as well as to men, but the collection was restricted to Government officials only and was not to be delegated to companies. No native was permitted to direct any police or military expedition, and the power to order operations was confined to a limited number of superior officials. The practice of using armed sentries to enforce labour was forbidden. Provision was made for the definite settlement of the country under native chiefs, who were to exercise certain administrative

1 The Commission held that mutilation was not in fact practised on the living, but that conclusion rested on evidence not disclosed.

${ }^{2}$ Cd. 3450, pp. 2 sq.

3 Elephant hunting was prohibited in 1889 (Masoin, Histoire, i. 61). 
and judicial functions and to communicate with the European authorities by native messengers. The Domaine privé was converted into the Domaine national, a mere change of title, and the Domaine de la Couronne was replaced by the Fondation de la Couronne. A special Council for the Congo, consisting of nine members, was established to advise the King on political questions. The judicial system was improved by the establishment of four new courts of first instance at Leopoldville, Stanleyville, Coquilhatville, and Nyangara, and by the grant to officers of the Ministère public of the status of Doctors of Law of the power to deal with petty civil and criminal cases.

Sir Edward Grey-readily admitted that the effective carrying out of the reforms might improve materially the situation, but the scepticism which he expressed was rapidly justified by the reports which were received from the British consular representatives in the Congo, ${ }^{1}$ and in the House of Lords on July 29, and the House of Commons on August 1, the opinion was general that a radical alteration of régime was the only method of reversing the policy of the State. But it was recognized that mere annexation by Belgium would be useless without a change of the spirit of the administration, and Sir E. Grey on February 19, 1907, laid it down that for its validity the annexation would require the consent of the Powers signatory of the Berlin Act. The Congo Reform Association also made a change of administration an essential condition of the acceptance as satisfactory of annexation. The delays in Belgium excited a growing spirit of disquiet: a public meeting under the presidency of the Lord Mayor affirmed on February 21 that any project of annexation which did not restore their liberty to the natives and re-establish the freedom of trade laid down in the Berlin Act would not be approved by the British people. Lord Cromer three days later lent the attack on the State his powerful aid, and on February 26 Sir E. Grey expressly declared that the State had lost its moral right to international existence, and 


\section{MALADMINISTRATION OF THE STATE}

expressed his readiness to give political effect to his statement. Such declarations were not unnaturally resented by Belgian patriots, ${ }^{1}$ but they served their purpose in hastening the momentous decision which transferred to the democracy of Belgium the responsibility for the government of the Congo.

1 The suggestion of Masoin (Histoire, i. 172) that the feeling of Britain was due to aims of annexation is too absurd to require refutation. It is characteristic that the author never alludes to Germany's obvious designs on the State (below, Chapter XII, § 2). 


\section{CHAPTER X}

THE ANNEXATION OF THE CONGO TO BELGIUM

Ir is a convincing proof of the ability of Leopold II and of the indifference of the Belgian public to the value of the Congo that he should so long have been able to delay the transfer of the Congo to his people. The agreement of 1890 contemplated that in ten years the transfer would be effected, and in July, 1893, on the revision of the Belgian Constitution, a clause was added, permitting the holding of colonies or protectorates by the country, special provision being made that such territories should be governed by special codes of law, and not by the Belgian codes, and that European soldiers for their defence should be raised by voluntary enlistment only, a provision destined to prevent men raised for national service in Belgium being employed overseas.

The King had bound himself by the agreement of 1890 not to contract any loan without the consent of the Belgian Parliament, but the expenses of the State, despite the Belgian contribution and the King's own grant, a million francs annually, continued to advance by leaps and bounds, increasing from 4,500,000 francs in 1891 to $7,500,000$ in 1894. With an indifference to his honour which is surprising even in a monarch, Leopold II in November, 1892, borrowed five million francs from an Antwerp banker on the security of sixteen million hectares of land, which were to be forfeited if the loan were not repaid on June 30, 1895. By the end of 1894, it was clear that the loan would not be repaid: the treasury was empty, ${ }^{1}$ and the commercial

1 The King's straits are described by Masoin, Histoire, i. 29, who (i. 188-221) gives a good account of his measures to avoid annexation, which even he does not approve. 
companies, foreseeing the prospect of crushing taxation, ) demanded annexation to Belgium. The King had recourse to his Ministers, who, on December 20, 1894, decided to propose annexation, and on January 9, 1895, a treaty of cession was prepared, and presented on February 12 to Parliament by the Minister for Foreign Affairs. The treaty was unhappily prejudiced by this delay, which was caused by the necessity of arranging with France for the reassertion by a treaty of February 5 of the right of pre-emption possessed by that Power, and a violent campaign was started against the proposal. It was argued that the Congo was worthless, a second Panama, that its products would compete with Belgian labour, that it would be expensive to maintain, and that Belgian soldiers would have to defend it. The Labour party was wholly opposed to colonial adventures, and unanimous in opposition. On the other hand Thys and Wauters eagerly defended annexation, and it was supported by the Chambers of Commerce of Antwerp, Ghent, Brussels, and Liège, and by associations such as the Cercle africain, the Société d'études coloniales, and the Comité d'action pour l'œuvre nationale africaine. Nothing could have suited the King better than this division of opinion, which rendered the Ministry indifferent to the project. The advent of Félix Faure to the Presidency had secured him prospects of better relations with France and of aid in his projects on the Nile, and throughout his career he showed the most lively anxiety not to lose his personal control of the government of the State. The reluctance of the King was reflected in the proceedings of the Commission of twenty-one members, which protracted its task in the lack of information which it demanded but did not receive. On May 18 the President, de Lantsheere, suggested that provisional steps were necessary to secure that. the lands pledged by the King did not pass away from the State: Woeste, the Catholic leader, agreed to this suggestion, and on May 24 this view was adopted by the Commission. A cabinet crisis followed: M. de Mérode, who had accepted the responsibility for the measure, resigned, and on June 14 
the Government asked Parliament to agree to a further loan of seven million francs to the State to enable it to pay off the loan and to meet its pressing liabilities. The proposal was accepted by both houses on June 27 and 28, and on September 12 a new agreement withdrew the treaty of annexation: the debt due by the State to Belgium was now fixed at $32,000,000$ francs, to be repaid in 1901 with interest at 3 per cent. if annexation did not then take place. ${ }^{1}$

Annexation was therefore due in February 18, 1901, and $L$ public opinion had long since definitely accepted the desirability of this course. On February 15, however, the Premier, Count de Smet de Nayer, intimated to Parliament that it was proposed, with the assent of the State, to postpone discussion on annexation until after Easter, in order not to interfere with the business of the House. On March 28 the Government explained its policy : it proposed to postpone the repayment of the loan by the State and to delay annexation pending the elaboration of a colonial law. The proposal was far from attractive either to the party which held that annexation was best for the State and Belgium, or to those who disliked the personal authority of the King, and Beernaert on May 29 proposed as an alternative the immediate annexation of the Congo by the State, leaving the State to administer it in the meantime. The King intervened: he addressed to Woeste a letter which the latter read on June 11, and in which he insisted on the uprightness of his motives in asking that he should be allowed to complete his work in the Congo before transferring it to Belgium. Beernaert yielded before this personal appeal, and on July 17 and August 10 the Chambers voted the law which postponed the repayment of the loans due to Belgium and affirmed the right of Belgium to annex the Congo at an indeterminate date, while releasing the King from any obligation to obtain the assent of the Belgian Government for contracting new loans. The King, in return, agreed to ${ }^{\vee}$ the presentation on August 7 to the Chamber of a draft law

${ }^{1}$. Hertslet, Map of Africa by Treaty, ii. 546, 547. 
on colonial organization, which was, however, allowed to slumber in oblivion.

The revelation of the crimes committed in the Congo rendered the maintenance of the status quo impossible, but the King was not disposed to surrender his position without a struggle. Contemporaneously with his reform proposals of June 3 he issued a declaration ${ }^{1}$ which asserted in terms of singular arrogance the exclusive right which he possessed over the Congo; the absolutely sovereign condition of that State; and the necessity of Belgium deriving her title to it solely from him. He intimated in very clear terms that, while it would be his duty to inform Belgium when in his opinion the time had come for the transfer, that period had not arrived, and the State was not ripe for control by a Parliamentary Government. He added a note ${ }^{2}$ on the conditions in which annexation could take place, asserting that indispensable conditions were the assumption by Belgium of all the obligations already undertaken by the State, including those affecting the Domaine national and the Fondation de la Couronne, the revenues of the latter, then placed at 7,000,000 francs ${ }^{3}$ annually, being destined for works of value to Belgium, the creation of a commercial marine, the encouragement of arts and science, the improvement of the conditions of the working classes, the provision of the Musée de Tervueren, ${ }^{4}$ the equipment of an École mondiale, ${ }^{5}$ and similar projects.

So proud a challenge could not fail to meet with a reply from a high-spirited people. M. Hymans brought the matter before the Chamber on November 28, and a three weeks' debate followed: the Liberal party declined absolutely to accept the obligation respecting the Fondation de la Couronne, and at last the King yielded, and authorized de Smet de Nayer to announce that his views on the

${ }^{1}$ Cd. 3450, pp. 4-7.

${ }^{2}$ Ibid.p. 8.

${ }^{3}$ Cattier's estimate; four to five millions according to de Sinet de Nayer.

4 Definitely founded in 1897.

${ }^{5}$ Begun in 1905; see Masoin, Histoire, i. 77, 78. 
Fondation were merely solemn recommendations. The Chamber then all but unanimously reaffirmed the resolution of March 2, 1906, in favour of the immediate consideration of the colonial law, expressed the desire that annexation should be effected in the King's lifetime, and took note of the explanation given of his wishes. The King was deeply disappointed by the decision, but the case against the Fondation was convincing: the profits which it was proposed to use in beautifying Belgium had been extracted from the Congo by a policy of appropriating the land of the country and by forced labour : to have persisted in drawing them would have placed the Belgians in the wholly unjustifiable position of drawing large tribute from a native colony.

In December, 1906, the task of revising the colonial law was entrusted to a commission of seventeen members, and by May, 1907, it was possible to assure the Chamber that the Bill was far advanced and that negotiations were about to be undertaken with the State. The actual discussion began on July 8 and ended in the treaty of November 28, by which, however, despite the clear intention of Parliament, the Belgian Government bound itself to respect the Fondation de la Couronne. In the meantime, too, the King had created a new fund, the Fondation de Niederfullbach, ${ }^{1}$ on September 7, to which he presented Congolese shares valued at 30 to 40 million francs, and had dedicated the fund to purposes which included the expenditure of $26,000,000$ francs on works in Belgium, a transaction equally discreditable to the King and to M. Renkin, the Minister in whose sphere the matter lay. Naturally the treaty was received with indignation, but the death of de Trooz, the Premier, delayed a decision, and it was not until after receiving a strong letter from the Cabinet on February 24, 1908, that the King agreed to suppress by decree of March 5 the Fondation on the occurrence of annexation. Schollaert, to whom as Premier the credit for

${ }^{1}$ Masoin (Histoire, i. 211, n. 1) attempts to defend the King, but only by assuming a different code of morality for private persons and kings. 
the decision is due, brought the treaty, with the necessary additional Act and the decree suppressing the Fondation, before the Commission on March 5, and on March 25 the documents received its approval along with the final draft of the colonial law.

The treaty of cession was based on the simple acceptance by Belgium of the whole assets of the State and of its debts without inquiry or examination. The assets were placed at 110 millions, in addition to the lands of the State, including the buildings and material of the State, ivory and rubber valued at 15 millions, securities worth 60 millions, and certain property which had been retroceded by the Fondation de la Couronne under an agreement of December 24, 1906. The debt consisted of 110 millions, the amount of successive Congo loans, with an annual interest of some 4 million francs, counterbalanced by an equal revenue from the securities among the assets. The additional Act provided for the changes necessary in view of the suppression of the Fondation de la Couronne. The State received the immovable property of the Fondation in the Congo, property in Belgium and France worth 4 millions, and 60 millions of securities. It undertook the payment of . certain annuities to Prince Albert and Princess Clémentine and to the personnel of the Fondation, of 65,000 francs annually to the Pères de Scheut, and of 400,000 francs to the Colonial Gardens at Laeken. The State also bound itself to expend from Belgian funds 45,500,000 francs to carry out on a diminished scale the great public works which the King had intended to create in Belgium from the revenues of the Fondation. Finally, the Congo Budget was to bear a burden of $50,000,000$ francs, payable in fifteen instalments, the sums to be assigned by the King to such purposes in the interest of the natives and white men in the Congo as he might think fit.

The discussion of the proposals opened in Parliament on April 15 and was prolonged to July 15 . From the first ${ }^{1}$ the

${ }^{1}$ All idea of yielding to foreign pressure was, naturally, indignantly 
discussion was motived by the knowledge that the United Kingdom had on March 27,1 with the approval of the United States, laid down the conditions on which annexation would be recognized. The old cries against annexation were raised; it was claimed that it would mean the creation of a colonial navy, of a colonial army, and involved grave burdens on the State; and the general election in May reduced to eight from twelve the majority of the Right, a result which the Socialists claimed to be due to the annexation scheme. The King seems to have made a last effort to recover his position : a mysterious interview took place at Wiesbaden with the German Emperor and the Imperial Chancellor ${ }^{2}$ : the Prime Minister and the Minister of Justice were summoned to a consultation, and the explanations demanded in the Chamber on June 17 were refused. M. Renkin, the Minister of Justice, argued at great length that the administration of the State was in no way opposed to international law, and that there was no risk of pecuniary burdens falling on Belgium; and finally, on July 15, the discussion of the treaty ended. It was followed by the examination of the colonial law, and on August 20 a final vote of 83 to 54 decided in favour of the annexation and the law. The Senate on September 9 accepted the same result by 63 votes to 24 ; on October 18 the annexation was promulgated; on October 30 an arrêté created a Ministry of the Colonies, to which office M. Renkin was appointed. On November 15 the annexation became effective in the Congo, and the State flag made way for the Belgian ensign. The change was greeted coldly in Belgium save that the Cardinal Archbishop of Malines and the bishops issued a pastoral letter, which was read in the churches on November 1, and

repudiated on -all sides, but the arguments played repeatedly on this, essential, aspect of annexation.

${ }^{1}$ Cd. 4135, pp. 2-34.

2 The King probably found that help from Germany would compromise the Belgian claim on the Congo, and it is notorious that he recognized the danger of those German designs on Belgium itself, to which Count von Bissing's testament bears witness. 


\section{ANNEXATION OF THE CONGO TO BELGIUM}

a Te Deum chanted in honour of the great accession thus made to the power and prestige of Belgium.

It remained to make terms with France as in 1895 regarding the recognition of the right of pre-emption. This was accorded by a treaty of December 23, and a contemporaneous agreement placed under French control the island of Bamu, but required that it should be neutralized in perpetuity. Another agreement disposed of doubts as to a small section of the Congo-French boundary on the Congo. ${ }^{1}$

1 Hertslet, Map of Africa by Treaty, iii. 1226 ; E. Payen, Belgique et Congo, pp. 91, 92 ; the treaty of annexation, the Additional Act, and the decree of March 5, 1908, are given, ibid.pp. 106-20. 


\section{CHAPTER XI}

\section{THE BRITISH CASE AGAINST THE CONGO AND THE BELGIAN REFORMS}

\section{The British Case against the Congo.}

$\mathrm{By}$ the annexation to Belgium the State had undergone in the eyes of Belgium a definite change of ownership, but the United Kingdom had already given clear notice that it would not accept any change unless satisfied that the administration would be so reorganized as to carry out the intention of the founders of the State as expressed in 1884-5. The United States also in January, 1909, adopted the same attitude, and it was of little avail for the Belgian Government to argue that the transfer had de jure already taken place and that British or American recognition was unnecessary for its validity. The Government of Belgium could not ignore the charge of inhumanity in modes of government which the King was able to despise, and it showed an increasing readiness to meet with more than a mere negation the remonstrances and suggestions of the British Government. The process of modification of the attitude of the Belgian Government was a slow one: M. Davignon, in a dispatch of April 25, 1908, ${ }^{1}$ showed little sign of appreciating the weight of British opinion, and on May 27 Sir E. Grey had to discuss the possibility of blockade of the Congo as desirable but for considerations of international character. A mass meeting at the Albert Hall, under the presidency of the Archbishop of Canterbury, on November 19 showed that the British people were more and more earnest in their desire for reform. Happily for Belgium and the United Kingdom, the death of Leopold II

1 Cd. 4135, pp. 34 sq. ; cf. Cd. 4178, pp. 4 sq. (note of July 12, 1908). 
removed the main barrier to an understanding, for his successor, King Albert, had already travelled in 1909 in the Congo, and was animated by a spirit of magnanimity and humanity strangely at variance with the colossal egoism of his predecessor. Although in his rôle of constitutional sovereign his direct power as regards the Congo was nominal, he was ever ready to co-operate with his ministers in measures for the advancement of the interests of the natives of the Congo, and the effect of this spirit on the Ministry was easy to recognize.

$q$ The remonstrances addressed by the United Kingdom to the State and on annexation to Belgium-though without acknowledging the validity of the annexation-may be grouped under three heads: the question of international law; the treatment of the natives; and interference with freedom of trade and of missionary action. On the question of international law a direct contradiction existed between the view. of the two parties, for the attitude of the State was accepted later by Belgium. The United Kingdom ${ }^{1}$ claimed that Article VI of the Berlin Act, which bound the Powers to watch over the native races and to care for the improvement of the conditions of their moral and material wellbeing, gave to the United Kingdom a right to claim from the Congo the faithful execution of the stipulations made. The Congo declared that the article was a declaration of general principles and intentions with regard to the treatment of the natives, which conferred no right of intervention either individually or collectively on the signatory Powers, a contention which obviously was open to the retort that it made the article meaningless, and the Belgian Government endeavoured, in communicating as it did to the United Kingdom statements of its intentions in regard to native administration, to give them the appearance of semi-official communications. ${ }^{2}$

The gravamen of the British case as to the treatment of

${ }^{1}$ Cd. 4135, p. 2 ; cf. the clear exposition in Cd. 6606, p. 22.

${ }^{2}$ Cd. 3002, p. 19; Cd. 5860, p. 101 (remarks of M. Renkin, October 26, 1911). 
the natives ${ }^{1}$ was that the State had deprived them of their land, reducing them to a servile status compelled to incessant labour for the State or concessionary companies in which the State was interested, and whose profits served to promote European interests alone. This result was the product of a combination of factors, of varying degrees of importance. The commercial policy of the State turned its administrators into collectors of produce and the agents of companies into tax-gatherers; both the State and the companies paid their servants ludicrously small salaries, but offered large bonuses in one form or other for the collection of produce, and their overworked officials, kept far too long in an unhealthy climate, inevitably fell into the habit of delegating their powers to native chiefs or soldiers, but little removed from barbarism, over whom they were helpless to exercise any effective control. The State allowed its profits to render it indifferent to their actions, and assassination, the only protection of the natives, brought in its train massacres and pillage.

The native might, under an organized régime, have found protection from his chief against the oppression of officers of the State, but the policy of the State aimed at the overthrow of the established chiefs, in whose place it set its own nominees, often ex-soldiers, whose only strength lay in the protection of the State officials, and who were therefore the subservient tools of these officers in exacting from their people the utmost possible labour in collecting the produce of the State, for which purpose the State troops were freely placed at their disposal. Wahis ${ }^{2}$ had already condemned the system before 1898, but in $1906^{3}$ and $1908^{4}$ alike cases of the employment of sentinels to coerce natives were reported. Moreover, the State made no effort to control the chiefs in their treatment of their subjects, who remained

${ }^{1}$ Cd. 1933, pp. 21 sq. Cd. 3002, pp. 3-5 (remonstrances addressed to the State); Cd. 4135, pp..2-34; Cd. 4178, pp. 1-3 ; Cd. 4396 (remonstrances addressed to Belgium).
${ }^{2}$ C. 8649-30, p. 12.
${ }^{3}$ Cd. 3450, pp. 33-5.
$4 \mathrm{Cd}_{\text {\& }} 4466$, pp. 31,33 . 
liable to inhuman punishments and unjust judgements without possibility of redress in the absence of effective European jurisdictions. ${ }^{1}$

Moreover, the native was subject to corvées of a severe character. From 1891 compulsory service was enforced for the army, and it had earlier been introduced for public works, especially transport and railway construction, building and the making of plantations. ${ }^{2}$ The reform legislation of 1906 fixed the period for civil work at five years, and for military service at seven. To some extent gain might accrue from training in systematic work, and military, service in certain cases doubtless made for civilization. $d$ But many of the natives perished from disease induced by contact with other tribes, many perished in the incessant wars, and most often on discharge, even if able to seek his former home, the worker would find his family extinct or vanished. Nor was much effective training given in superior methods of work: the native was allowed in the main to adopt his old processes, wasteful and ineffective as they often were. Even worse was the arbitrary nature of the work exacted from those who were not recruited for a definite period, but ordered from time to time by the local officials to undertake special work, for the arrangements were made by the local chief, who could abuse his position to cast the work on those whom he disliked, without possibility of effective appeal.

Even of greater consequence was the appropriation by the State of everything in the country save the miserable $d$ wellings of the natives and the patches of cultivated land around them. This step deprived the people of the normal and legitimate means of enriching themselves and paying the taxes of the State by collecting the rubber and ivory and, in a minor degree, the gum-copal which could be found in the adjacent forests, as had been their wont before the imposition of the rule of the State. The natives became

${ }^{1}$ Cf. Johnston, George Grenfell, i. 460, 461.

${ }^{2}$ Cf. C. $8649-30$, pp. 9,10 ; Johnston, op. cit. i. 471, 459, 460. 
thus in effect predial serfs, and as late as $1906^{1}$ the notorious Abir Company claimed, and the Commissioner of the Equator admitted the claim, that the natives within the area of the Company's concession could not be hired by any person without their consent.

The native, thus deprived of any means of obtaining more than bare subsistence, if even this was possible, was asked to pay taxation ${ }^{2}$ which he neither had nor could have money to meet, though if by working for Europeans he had obtained money it might be refused despite the authority which the law gave to pay the tax in cash. In effect, therefore, native taxation took two forms. The native might be ordered to supply posts where European or native employees of the Government were stationed with supplies of foodstuffs, ${ }^{3}$ especially chickwangue or manioc bread, for which the State as ' un acte de pure condescendance' gave a small payment in trade goods. In itself the tax might be perfectly reasonable if the amount to be supplied was small, but in the case of great stations like Leopoldville the burden on the women and children and domestic slaves, to whom the natives delegated the work, was crushing. The chickwangues had to be carried as much as eighty kilomètres, and many natives spent their time in toil, diminishing the birth-rate and depressing the social condition of the people. The payment in trade goods was a mockery, for while the chickwangues were valued far too low the trade goods were priced at fancy figures. In the alternative the native might collect rubber, in which case, as the rubber was State property, he was paid not for the produce but for the labour. The amount of the work to be done was left in practice to the local official; the decree of November 18, 1903, which fixed the period at forty hours, was probably never meant to be enforced, and in practice it was entirely neglected; a careful experiment made under conditions

${ }^{1}$ Cd. 3450, pp. 40-3, 55.

${ }^{2}$ Cd. 3880, pp. 58-62; Cd. 4135, pp. 14-32 ; Cd. 4466, pp. 44-50.

3 Dried fish and fowls were also demanded; Masoin, Histoire, i. 100, 101, admits the existence of abuse. 
favourable to the State by the United States Consul-General at Boma showed that the time taken to collect the rubber required at Yambata averaged 19 days 5 hours a month, while the-remuneration for the amount gathered (3 kilos.), valued at Antwerp at 37 fr. 50 c., was a machete, probable value $25 \mathrm{c}$., and a small handful of salt. Labour like this could, of course, be procured only by supervision by armed sentinels, by the terrorizing of those who rebelled, by punitive expeditions conducted often by negro soldiers, by taking as hostages women and children, by flogging, and, as the law permitted, by imprisonment. ${ }^{1}$

A minor, yet not unimportant, grievance was the faulty character of the labour contracts permitted by the Government. These contracts applied both to Congolese and nonCongolese natives, and were open to criticism on the score of the time-seven years-for which they were valid, the lack of effective explanation of their terms to the recruits, their enforcement by penal means, including even in the State's contracts ${ }^{2}$ corporal punishment, and above all the lack of any effective supervision of the treatment of the employees by the employers in whose power they were placed.

On the score of interference with trade the British case rested on the complete freedom of trade proclaimed by Article I of the Berlin Act and the prohibition of monopolies by Article V. ${ }^{3}$ They maintained that the concessionary régime in the Congo was a direct negation of these principles, for the policy of the State deprived the native of any means to trade with merchants not holding concessions. Nor to this complaint was any effective reply possible; the French Government, which had in an unhappy moment adopted the same régime in the French Congo, had by 1906 recognized the untenability of the position and made repara-

1 Even Masoin (Histoire, i. 96) admits abuses of power, but contends the guiltlessness of the State.

${ }^{2}$ Cd. 3450, pp. 20, 21.

${ }^{3}$ Cf. the German indictment in 1895 , C. 8276 , p. 99. 
tion for British losses through their action. ${ }^{1}$ The British Government also represented that both merchants and missionaries had been unable to obtain the land necessary for their business and missionary enterprise, despite the clear terms of the Act. ${ }^{2}$

As remedies for these evils the British Government proposed in its note of March 27, 1908, the following reforms: (1) Relief of the natives from excessive taxation. (2) The grant to the natives of sufficient land to ensure their ability to obtain not only the food they require but also sufficient produce of the soil to enable them to buy and sell as in other European colonies. (3) The possibility for traders, whatever their nationality may be, to acquire plots of land of reasonable dimensions in any part of the Congo for the erection of factories so as to enable them to establish direct trade relations with the natives.' As means to secure these ends they suggested the introduction of currency, promised by the King in 1906 but never carried out, as the most efficacious way of dispensing with the necessity of the labour tax; the taking of steps to secure that the natives should not be compelled either directly or indirectly to work without remuneration for concessionary companies; and the provision of much wider areas than contemplated even in the reform decree of 1906 for the use of the natives. In the long discussion ${ }^{4}$ which ensued, stress was laid on the argument that it would be unsatisfactory if the decree of 1906 were merely interpreted to secure to the natives adequate ground to supply them with food, since the problem of freedom of trade would thus be in nowise advanced, and in a memorandum of June 11, 1909, ${ }^{5}$ it was pointed out that in the Leopoldville district the taxation imposed amounted to 40 per cent. of the earnings of

${ }^{1}$ Humbert, L' Euvre française aux Colonies, pp.46-65; E. D. Morel (The British Case in French Congo) gives the British case.

${ }^{2}$ Grenfell protested against this in 1885 (Johnston, i. 445). It was still a grievance in 1908 (Cd. 3450, pp. 20, 21).
${ }^{3}$ Cd. 4135, p. 2.
${ }^{4}$ Cd. 4178,4396 , and 4710.
5 Cd. 4710, p. 11. 


\section{2}

Government employees, and that in one case, because the full tax had not been paid by the villagers, twenty-six men and boys, who had paid their own share, were cast into chains and marched twenty-six days' journey to a State post, where they were detained in penal servitude for six weeks.

\section{The Belgian Reforms.}

In estimating the action of the Belgian Government in proceeding to reforms, due weight must be allowed to its difficulties. The local administration was in the hands of men used to the old régime, and the Congo unhappily ranks in Belgium as the best place for the export of men of whom the country is tired. ${ }^{1}$ Moreover, the adoption of a new policy would mean heavy financial deficits which no government could very light-heartedly face, when contrasted with the lavish returns of the old régime. But, though slow, the reforms have been generous and on a large scale, and the different representations of the British Government have one by one been met in whole or part.

The old association of governmental and commercial functions had been definitely broken by the clause of the charter $^{2}$ which forbids the entrusting of administrative functions to commercial companies, and by the definite decision of the Government to abandon the suggestion that it should still continue to develop certain estates, including rubber and forest land, by its own means. ${ }^{3}$ The pay of the officers of the State has been raised to much the same level as in Nigeria, while the reduction of the term of service to two years should prevent breakdowns due to climatic conditions. ${ }^{4}$ At the same time the decentralization of the administration has rendered control more effective, and the

${ }^{1}$ Masoin, Histoire, ii. 401, 402 ; similar evidence as to the officials in the Katanga is given by Mr. Vice-Consul Campbell (August 12, 1912 ; Cd. 6606, p. 56).

${ }^{2}$ Art. 22.

${ }^{3}$ Cd. 6606, p. 114, a decision meeting the dangers urged by Mr. J. H. Harris, ibid. p. 8.

${ }^{4}$ Cf. Cd. 6606, pp. 18-22. 
reorganization of the judicature has presented a means of redressing abuses unknown under the old régime, though even now administrative acts are not subject to control by the ordinary civil tribunals of the State. The reorganization of the tribal system has been followed by an effort to control excesses by the native chiefs, though they still retain too much power, having the right to prevent the migration of their people, and though the natives fear to use their right of appeal to European tribunals. ${ }^{1}$ A great boon, however, has been conferred by the limitation of the use of the corvee : the period of service was reduced in 1910 to three from five years, and before the war its employment had been frankly abandoned, though necessarily this has been modified during war conditions. ${ }^{2}$

Equally important has been the change in land policy. During Leopold's lifetime the Domaine national remained as firmly closed as ever, but his death was followed in February by regulations ${ }^{3}$ regarding sales and leases of land to Europeans and others which removed a standing grievance of traders and missionaries alike, and a decree of March 22, 1910, ${ }^{4}$ proclaimed the termination of the State monopoly of the vegetable products of the domain in three instalments, ending for one part of the territory on July l, for a second on July 1, 1911, and for the remainder on July 1, 1912, imperious reasons of finance forbidding the application of the rule to the whole territory forthwith as suggested by the United Kingdom. Thereafter the produce could be collected by any person holding a permit, which was to be issued free of cost, save in the case of rubber or gum-copal, when 250 francs charge was to be made, but a native of the Congo could collect without a permit if he did not export directly. The right was subject to any rights of third parties already created by sale, lease, or concession from the State or henceforth to be created, and the State

${ }^{1}$ Cd. 5860, pp. 3, 4, 20-6 ; for the Government's efforts to remove abuses, see p. 50 .

${ }^{2}$ Cd. 5860, pp. 4, 26-8; Cd. 6606, p. 2.

${ }^{3}$ Cd. 6665-1, pp. 26, 27.

${ }^{4}$ Cd. 5559. 


\section{THE BRITISH CASE AGAINST THE CONGO}

reserved for itself the plantations already made by it and five forest areas each of 600,000 hectares. The right to collect could only be withdra wn by decree, but the GovernorGeneral might temporarily suspend it. The decrees of 1892 and 1906 regarding the domain were annulled, and rules to ensure care in collecting the rubber were enacted. These measures would have been inadequate but for the conclusion of contracts ${ }^{1}$ with the Abir and Anrersoise Companies under which the areas under their control fell from 15,000,000 hectares to 110,000 , while in return the Government surrendered its shares in their capital, the new arrangements becoming effective on February 5, 1913, a delay of eighteen months being accorded to simplify the financial question. ${ }^{2}$ The Government withdrew also from participation in the Kasai Company, accepting 11,180,103 francs for an interest valued shortly before at $35,000,000$, while another agreement of December 30,1912, ${ }^{3}$ reduced largely the area of $1,100,000$ hectares of the concession of the Union forestière et minière. In ivory the Government still maintained a claim to a half share in its value, but a decree of April 26, 1913, introduced a new system of taxation which, it was estimated, would reduce by a half the receipts of the State. Finally, the decisive step of paying all the State servants in specie was introduced from January $1,1912,{ }^{4}$ and under the new régime the companies are forced to adopt the same course.

In taxation a fundamental change has been introduced by the collection under a decree of May 2, 1910, of the sum due-fixed first at from four to twelve, and since 1914 at from two to twenty-five francs-in cash, ${ }^{5}$ which the native can now easily earn. Remissions are carefully regulated in suitable cases, and in lieu of forced food levies for the support of Government posts these have been made self-subsisting in many cases by the development of plantations round them,

${ }^{1}$ Cd. 5860, pp. 91-100.

${ }^{3}$ Cd. 6606, pp. 36, 114.

${ }^{2}$ Cd. 6802, p. 18.

4 Cd. 6606, p. 113.

${ }^{5}$ The rate may always be lowered; in 1912 it was 2.50 to 12 francs ; Cd. 6606, p. 114. 
while in other cases purchase for cash from the natives has supplanted commandeering and payment at nominal rates in trade goods.

Labour contracts have shared in the general improvement: in addition to the reduction of the period to three years, ${ }^{1}$ and the insertion in clear terms of the obligations imposed, some measure of supervision has been applied to the actions of employers, though much remains to be done.

With the solution of the land question there have disappeared many of the evils of the old régime. The difficulties formerly placed in the way of the acquisition of land by missionaries and traders appear effectively disposed of by the royal regulation of February 23, 1910, and the vast areas under concession have been enormously reduced, though the Compagnie des Grands Lacs, the Lomami Company, and the Sociéte anonyme belge have still considerable areas under their control. The most formal assurances have, however, been given by Belgium of her intention to carry out in spirit as well as in letter the Berlin Act, ${ }^{2}$ and in $1912^{3}$ formal notification was given to the British Government that, if groups of natives applied for lands in the domain for the purpose of cultivation for domestic use or profit the lands would be freely granted to them, on the sole condition that they should be developed within a period to be agreed upon between the natives and the local authorities in each case.

There are, it is true, abuses still in existence. - The loss to British and foreign trade generally by the concessionary régime cannot be made good by the mere modification of the concessions: as M. Vandervelde ${ }^{4}$ has pointed out, the effects of a trade monopoly will long hamper dealings in the Congo, as has been shown in the case of the concessionary companies in the French Congo even since their concessions

1 Decree of August 17, 1910 ; Cd. 5860, p. 4.

${ }^{2}$ Cf. also M. Renkin's speech to the International Colonial Institute ; Cd. 6606, pp. 44-9.

${ }^{3}$ Cd. 6606, p. 39.

4 Cd. 5860, p. 90 ; cf. Cd. 6802 , p. 3. 
have been retrenched. ${ }^{1}$ Nevertheless the welcome accorded to Messrs. Lever in the establishment of factories for palm products, which are already making much profit for the natives, whom they supply with regular work at good wages, is proof that great firms can make profits and prosper. ${ }^{2}$ At the end of $1911 \mathrm{M}$. Vandervelde ${ }^{3}$ brought forward many cases of abuse in the Congo, alleging that many of the children in the fermes chapelles of the Jesuit Fathers at Kwango were really stolen from their parents; that the Fathers used flogging and confinement in chains as modes of correcting those under their care; that they connived at illegal distilling; that many of the workmen brought to the posts as volunteers were really under coercion; that they were underpaid ; that there had been interference in individual cases with the course of justice; that there was a tendency in the colony to subject judicial officers to administrative control; and that punitive expeditions had been needlessly many. The replies of the Minister for the Colonies showed that there was at least some substance in these complaints. At a later date, March 7, 1913, ${ }^{4}$ M. Vandervelde drew attention to an important report by Mr. ViceConsul Purdon, ${ }^{5}$ which showed that in the latter part of 1912 the Lomami Company was practically exacting through their chiefs forced labour in the production of rubber from the natives in their concession. 'The native', Mr. Purdon wrote, ' in the greater portion of the unfrequented districts visited by me is purely and simply a machine for the enrichment of the State and trading companies. His opinion is not consulted when it is a question of work for the State, and his moral welfare is something too utterly remote to be considered.' ${ }^{6}$ M. Vandervelde also drew attention to a report by Mr. Consul Lament ${ }^{7}$ on his tour in the Uele and Aruwimi districts in 1912, in which he stated that the villages near the State posts were compelled to furnish them

${ }^{1}$ Cd. 7048-66, p. 5.

${ }^{3}$ Cd. 6606, pp. 3-6; cf. M. Hymans, ibid. p. 13.
${ }^{4}$ Cd. 6802, p. 38.
${ }^{s}$ Cd. 6606, p. 108.
${ }^{5}$ Cd. 6606, pp. 106, 107.
${ }^{7}$ Cd. 6606, p. 84 ; Cd. 6802, p. 39.

${ }^{2}$ Cd. 7620-103, p. 11. 
with provisions, and that the villages on the Kanwadoromo route had to make similar contributions to the mining camps of the Union forestière et minière at Kanwa. The Minister in reply in effect admitted the truth of the allegations by declaring that the Government were determined to take measures if necessary to cause the rights of the natives to be respected in the Lomami as they were in other parts of the Colony. To an interpellation by M. Vandervelde on the same occasion regarding murders committed by a certain Martin he was able to reply by showing that the man in question was suffering from sleeping sickness, while in other cases effective punishment of outrages has been secured. ${ }^{1}$

The evil of punitive expeditions merely for the sake of compelling chiefs to collect rubber was not unknown even in $1912,{ }^{2}$ and the Government had not then succeeded in dealing effectively with some of the chiefs such as the notorious Zapo-Zap of Luluabourg, who has evaded the just punishment of his misdeeds towards his subjects by loyalty to the State, ${ }^{3}$ but episodes like this are essentially transient conditions and of no serious importance in measuring the progress of the State.

Less satisfactory is the evidence of friction against foreigners which is yet seen in the Katanga, ${ }^{4}$ induced in part no doubt by dread of foreign interference. There is much weight in the protest of Mr. Vice-Consul Campbell ${ }^{5}$ in a letter to the Vice-Governor-General of that province of July 25, 1912: 'Were the laws administered generously and impartially as they should be in a new country, if prosperity is the aim, I think that traders of all nationalities would conform thereto, but they resent being regarded as outcastes because they are foreigners, and that this is the case $\mathrm{T}$ have been told over and over again both here and in the interior. It was a Belgian trader who informed me that a favourite theme of the officials in the interior was "Katanga for the. Belgians, and let the English and Germans go to their own

${ }^{1}$ Cd. 6606, p. 59.

${ }^{3}$ Cf. Johnston, George Grenfell, i. 440, 441.

${ }^{4}$ Cd. 6606, pp. 59-72.
${ }^{2}$ Cd. 6606, p. 54.

${ }^{5}$ Cd. 6606, p. 72. 
colonies"; while a German, whose agents have travelled widely in the district, remarked, in complaining of the feeling of insecurity which he and his employees shared, that the Katanga is full of young and inexperienced officials, who have no idea of free trade for all nationalities alike, and who consider it to be their duty to assist their compatriots to the detriment of foreigners.'

Too much stress must not be laid on these considerations, and it was undoubtedly a just balancing of what had been accomplished and what remained to be done that induced the British Government on June 27, 1913, ${ }^{1}$ to express to Belgium the formal recognition of the transfer of the Congo which it had so long withheld. The motives of the British people in their defence of the natives of the Congo were shamefully misinterpreted in Belgium for many years, where commercial or religious interests were believed to be the real motive for philanthropy. The most effective answer to the accusation is the record of the actual reforms accomplished, which have in every case followed the model suggested by the United Kingdom, while it is the adoption of these reforms alone which has rendered it possible to maintain that it is just that the people of the Congo should have their destinies entrusted to Belgium, and for this result Belgium is deeply indebted to the persistent efforts of British diplomacy and in special to the far-seeing policy of Sir Edward Grey.

${ }^{1}$ State Papers, cvii. 352, 353. 


\section{CHAPTER XII}

THE DEVELOPMENT OF THE KATANGA AND THE GERMAN MENACE

\section{The Development of the Katanga.}

THE last years of the administration of the State had seen the prelude to the decisive development of the Katanga which was to be the most remarkable feature of the history of the Congo as a Belgian Congo. The vast mineral wealth of the Katanga was clearly of no importance until there was established effective railway communication, and financiers proved singularly unwilling to provide the funds necessary to secure the junction at Sakania of the Congo with the Rhodesian railway system. Finally, however, the energy of Mr. Williams prevailed, and on December 11, 1909, the arrival of the first engine at Sakania was duly fêted. A year later, on September 29, 1910, the line was complete to Elizabethville, and the way was prepared for the further railway construction which has provided effective communication between the Katanga and the mouth of the Congo.

The development of the Katanga rendered it desirable to secure for it government more effective than could ever be provided by a Governor-General at a vast distance, and it was therefore decided that the territory should be constituted into a Vice-Government-General practically independent in $\mid$ all matters of the Governor-General. To effect this it was necessary to determine the political powers of the Comite spécial, which, under the agreement of 1900 with the State, still held the full executive authority in the Katanga. The Charter ${ }^{1}$ contemplated the extinction of this régime not later than January 1, 1912, and the decree of March 22, 1910, accelerated the date. But the decree could, of course, deal 
only with the administrative powers of the Government, which it had conferred of its own will on the Comité, and that body therefore remains entitled to act as the guardian of the rights in common possessed over the lands of the Katanga by the State and the Katanga Company. On the other hand, the operations of the Comité are no longer subject to its own pleasures: it is bound by the Belgian legislation which regulates the terms of concessions of all kinds whether of land or of minerals, ${ }^{1}$ a derogation from its former rights which it might theoretically have resented. ${ }^{2}$ In fact, however, the majority of members appointed by the State gives the Government the full control of the Comité, which has thus the aspect of a governmental department, and an agreement of September 11 and 15, 1911, has appointed as its representative in Africa the Vice-GovernorGeneral of the Katanga.

The prosperity of the mines of the Katanga and its proximity to Rhodesia have, however, raised questions of no small complexity. The population, which was but 361 in 1910, rose to 747 in 1911 , to 1,760 in 1912, and to perhaps 2,500 on January $1,1914,{ }^{3}$ of whom 1,000 were at Elizabeth. ville. The Belgians number about half the population of the Katanga, but the economic dependence of the country on South Africa is obvious and undeniable. ${ }^{4}$ The native labour required for mining operations is largely imported from northern Rhodesia, and supplies of all kinds are drawn from Bulawayo, Salisbury, Johannesburg, or other South African sources. The natural railway outlet is to Beira, for the 1 Congo route is very much longer, and by reason of the breaks in its continuity is expensive as demanding transhipments. It is not unnatural, therefore, especially when it is remembered that the possession of the Katanga was once in dispute with the Chartered Company, that uneasiness should be common in Belgium as to the future of the territory, and

1 Art. 15, modified by a law of March 5, 1912.

${ }^{2}$ Lannoy, L'Organisation coloniale belge, p. 161.

3 Cf. Cd. 7048-120, p. 7 ; Cd. 7048-77, p. 3.

${ }^{4}$ G. de Leener, Le Commerce au Katanga (1911). 
that every effort should be made to secure the strengthening of the Belgian element of the population. An interesting experiment was made by a company formed under Governmentassistance to establish agricultural settlers by bringing them from Belgium, and after a year's work on the land providing them with land grants and aid in planting, while industrial workers were guaranteed two years' employment. ${ }^{1}$ The Government gave also free third-class passages, and obtained reduced rates on the South African railways. By these means 434 Belgians, including 41 farmers, 189 industrial workers, 89 women, and 80 children, were introduced up to June 30, 1913; but the effort collapsed, doubtless for the simple reason that the Belgian is not by instinct a colonizer, and the conditions to be faced were even harder than those of Northern Rhodesia, which are admittedly. trying enough. In 1913 the number of farmers and their families established in the Katanga was only thirty, and the problem whether the land is fitted for white settlement remains unsolved, though an affirmative answer is generally assumed. Doubtless neaar the towns vegetables, maize, and potatoes can be raised and produce remunerative prices to the few farmers engaged in the enterprise, but it is still a moot point whether agriculture is practicable on a large scale. Almost the whole country save the great plateau is heavily wooded, and experiments have not yet availed to prove the agricultural value of cleared land. In one case the soil when cleared proved too rich in iron to produce crops, while the work of removing tree stumps and ant-hills is excessively difficult and costly, and in the rainy season the roads cannot bear the traction engines needed for motive power, as the use of horses or cattle is forbidden by the prevalence of the tsetse-fly. Even, however, if certain areas should prove fit for cereals, cattle can hardly be used for ploughing, and the mines absorb the scanty labour supply, leaving the farmer helpless to secure labour at reasonable rates. Cattle-grazing on the plateau region promises better results as the railway offers facilities of transport, but valleys

${ }^{1}$ Cd. 6665-1, pp. 3, 18: 82 of these left promptly the Colony. 
free from fly for grazing purposes are hard to find. ${ }^{1}$. The Lulua district in the south offers better prospects, for the fly is not found south of $10^{\circ} 30^{\prime} \mathrm{S}$. lat. But in any event it is difficult to avoid the conclusion that settlement when it comes is more likely to be effected by Rhodesians familiar with the conditions of life and with the means of meeting them.

\section{The German Menace.}

The death of Leopold II carried with it the disappearance of the last trace of his great efforts to secure for the State the upper waters of the Nile. The Lado enclave was, in accordance with the treaty of 1906, evacuated on June 16, 1910. The delimitation, however, of the actual boundary provided for in that treaty proved unexpectedly difficult, the result of erroneous geographical information at the time of the definition of the boundary line. ${ }^{2}$ The decision of the final line involved agreement also with Germany, as it was requisite to determine anew the German boundary with the Congo, and the British boundary with Germany between Uganda and German East Africa. The Belgian boundary with Germany, according to the declarations of neutrality ${ }^{3}$ made by Belgium in harmony with the treaty of 1884 with Germany, was formed by Tanganyika, and north of that lake by a straight line to the intersection of $30^{\circ} \mathrm{E}$. long. and $1^{\prime} 20^{\circ} \mathrm{S}$. lat., and then along $30^{\circ} \mathrm{E}$. long. After discussion, therefore, a protocol was signed on May 14, 1910, which represented the agreement of delegates of the British, Belgian, and German Governments and laid the foundation for the settlement of the matters at issue. The agreement with Germany, which had been in some degree prefigured in a modus vivendi arranged in November, 1899, during the Congo operations against the revolted soldiers of Dhanis's

${ }^{1}$ Cf. Mr. Pearson, Cd. 6665-123, pp. 7-10, who is less optimistic than Mr. Manners; Cd. 7048-120, p. 6 ; Mr. Beak, Cd. 5465-129, pp. 5-7; Mr. Campbell, Cd. 6606, p. 55.

${ }^{2}$ Cf. The Times History of the War, x. 128.

${ }^{3}$ Hertslet, Map of Africa by Treaty, ii. 552, 553, 557-61. 
expedition, made some concession to Belgium as regards the islands in Lake Kivu and in the line to the north of the Lake. To this agreement effect was given by a convention of August 11, 1910, and the actual delimitation was in part carried out by a protocol of boundary commissioners signed at Goma, June 25, 1911. ${ }^{1}$ The agreement with the United Kingdom, which was conditional on the acceptance of the agreement with Germany, fixed a frontier advantageous for Belgium by giving that country a portion of the waters of Lake Albert. On the other hand, an exchange of notes provided for the grant to a British company of access by sale or lease of land to Lake Kivu, with permission to construct a road to the lake, on which, as on Lakes Albert Edward and Albert, navigation was to be free as under the Berlin Act. ${ }^{2}$

The Anglo-Belgian line in the region of Uganda was delimited by boundary commissioners from Sabinio to Mount Nkabwa, and their results recorded in a protocol of May 4, 1911. ${ }^{3}$ The line between the Sudan was provisionally settled by a joint commission on May 14, 1913. The matter was discussed further in 1913-14, and was finally disposed of by an agreement of February 3, 1915, dealing with the boundary line from Mount Sabinio, from which the delimitation of 1911 began, to the Congo-Nile watershed, summing up with slight changes the discussions of the preceding years.

The year 1911 saw the accomplishment of an aim long cherished by Germany but hitherto unattainable. Germany had been compelled in 1884 to accept the impossibility of securing a footing on the Congo, and her readiness to accord assistance to Leopold II had doubtless in no small measure been motived by the natural preference for the establishment on the Congo of a weak Power, whose possession of the country might not in future prove incompatible with the extension of German influence. In the earlier years of the development of the Congo, when Germany was interested

${ }^{1}$ State Papers, ciii. 372 ; civ. 820 sq.

${ }^{2}$ Ibich. cvii. 348.

3 Ibid. 349 sq.

L 2 
in the overthrow of the Arab power on Tanganyika, the attitude of Germany towards the State was not unsympathetic: it was largely owing to the facilities afforded by Germany that Captain Jacques was able in 1891 to make his expedition under the auspices of the Anti-Slave-Trade Society to the relief of the missionaries on the western shore of Tanganyika, ${ }^{1}$ and to found Albertville at the close of that year. A few years later, however, with the establishment of German control in her East African territory, the tone of the Government towards the State had undergone a marked change. It was the German Government which induced the British Government to take up in the first instance the case of the murder of Mr. Stokes, ${ }^{2}$ and in the course of the correspondence which arose from that episode, Germany was peremptory in her demand on the State for satisfaction, not merely of her demand for redress for the wrongs inflicted on the porters of Stokes's expedition, but also for the violation of freedom of trade of which the German Government accused the State. ${ }^{3}$ This accusation was based on the belief that the State Government paid its agents premiums on the acquisition of products of the country, especially ivory and rubber, and the German Government denounced such action as wholly incompatible with the Berlin Act. 'It is obvious', Count Alvensleben wrote on December 9, $1895,{ }^{4}$ 'that there can be no freedom of trade. with the natives, if on the one side simple traders carry on trade, and on the other side they compete with officials and employees acting as traders, who in their capacity as representatives of the Government have control over them and often the power of life and death.' The State Government waived the discussion of the point of law by giving the German Government a categorical assurance ${ }^{5}$ that no such premiums were given, and that they would not be given, a statement which can "hardly be characterized as anything but a deliberate falsehood. In point of fact the State had given bonuses,
1 Masoin, Histoire, i. 84 sq.
${ }^{2}$ C. 8276, p. 1.
${ }^{3}$ C. 8276, pp. 4, 6, 39, 57.
${ }^{4}$ C. 8276, p. 99.
${ }^{5}$ Ibid. p. 99. 
and when in 1895 it suppressed this system it was only to replace it by a system of ' points attribués par tonne récoltée', and on December 31, 1896, this was modified to a system of 'allocations dites de retraite'.'

Precisely the same spirit towards Belgium had been shown the year before in the discussion over the possibility of the grant to the United Kingdom of a commercial route under British control from the south to the north. The violence of the German protest would be inexplicable if it had not been motived by the view that the Eastern Congo at any rate lay within its sphere of influence, and that it was imperative to prevent the Congo falling in any way into the hands of a Power strong enough to prove a barrier to the fulfilment in due course of German ambitions. ${ }^{2}$ It is significant also that it was to Germany that the King of the Belgians seems to have looked in 1908 when he was seeking some mode of extricating himself from the painful necessity of relaxing his personal control of the government of the State.

The essential aim of Germany, the creation of a connexion by land between the eastern and western German territories, thus erecting a German empire over Central Africa, was made manifest by her policy with regard to the French/ Congo. It is probable, indeed practically certain, despite the official German denials, that her attitude in her dealings with France over Morocco between 1904 and $1911^{3}$ was aimed at securing territorial possessions in the north of Africa. For such a policy abundant excuse and explanation can so readily be found that démentis of such a conception can hardly be taken seriously. But it is characteristic of German diplomacy that, finding the resistance of the United Kingdom to the coercion of France was not to be overcome, it decided to make the abandonment of the effort to secure? part of Morocco an occasion for obtaining a substantial foot-i hold on the Congo. It is admitted that she desired much more than this, and that it was her aim to secure also the

1 Masoin, Histoire, i. 94, 95.

${ }^{2}$ Cf. R. Williams, United Empire, 1917, p. 452.

${ }^{3}$ See e.g. V. Piquet, Le Maroc (1917); M. Bourquin, Les Visées de l'Allemagne sur le Congo Belge, pp. 17 seq. 
transfer to her of the French right of pre-emption over the Congo, ${ }^{1}$ but this concession she was finally unable to obtain. Plainly indeed the transfer of the right of pre-emption would have been invalid without the consent of the other great Powers, which could perfectly well argue that, while they were, or might be held to be, bound by the French right, concluded before they recognized the State, they could not be bound by any transfer of that right made by France. In the event, while Germany had to reduce the extent of her claims on France, she acquired, in exchange for about 6,500 square miles in the Shari region, in French Equatorial Africa not less than 107,000 square miles of territory, much of it doubtless in itself not of the slightest value, both by reason of poorness of soil and prevalence of sleeping-sickness, but nevertheless of the greatest political value. The territory conceded by the treaty of November $4,1911,{ }^{2}$ and delimited elaborately by an agreement of September $28,1912,{ }^{3}$ was so shaped as to break up the continuity of the French colony of Equatorial Africa, ${ }^{4}$ two long arms of land running down to the Congo river from the now vastly extended territory of the Cameroons, and thus separating the Ubangi-ShariChad from the Middle Congo region, and that again from the Gaboon, while the southern boundary of the Cameroons was extended so as to enclose Spanish Guinea, the French Government transferring to Germany the right of preemption over that area, and to render the position of Libreville militarily untenable. Access to the Congo was secured by the cession of the Lower Sanga valley up to the confluence of that stream with the Congo, a frontage of from five to twelve kilometres being secured on that river, at about $1^{\circ} \mathrm{S}$. lat., while access to the Ubangi was secured by the cession of the valley of the Lobaye to its confluence with the Ubangi, a similar frontage being accorded on the Ubangi. These means of access were indeed

${ }^{1}$ M. Hymans in Cd. 6606, p. 13.

${ }^{2}$ Ratified March 12, 1912 ; State Papers, civ. 657 sq.

s State Papers, cvi. 975 sq.

${ }^{4}$ Cf. M. Merlin, cited in J. A. S. xiv. 43̈6-8. 
comparatively small, but the German Government in its defence of its exploits in the Reichstag ${ }^{1}$ made a special point of the value in the case of future changes of this access to the river, and, while the French right of pre-emption over the Congo was not ceded, it was especially agreed by Article XVI of the treaty of November 4, 1911, that any change in the territorial status of the conventional basin of the Congo as defined in the Berlin Act, brought about by the action of either of the contracting parties, would afford a ground for a conference between them and the other Powers signatory of the Berlin Act. By this agreement the dominant position of France with regard to the future of the Congo, if it ceased to be a Belgian possession, was definitely overthrown and the position of the Congo made a matter of international concern. It is not remarkable that the Belgian public viewed with anxiety the position, or that M. Hymans, ${ }^{2}$ in the course of the discussion on the affairs of the Congo which took place in the Belgian Chamber in February, 1912, should have admitted thut the position was full of anxiety and have exhorted his countrymen to show that they were capable of controlling effectively a colonial territory.

It seems that the German menace, coupled with the burden of developing the Congo with Belgian resources, prompted a movement in Belgium itself, doubtless more or less directly inspired by German influence, to consider the possibility of lightening the burden by the reduction of the unwieldy size-900,000 square miles-of the Congo territory. ${ }^{3}$ In his able plaidoyer in support of German interests in Africa, Africa and the Peace of Europe, Mr. E. D. Morel states that such a proposal was brought before his notice, and apparently communicated to the Governments interested, it being suggested that Germany, France, and the United Kingdom might take over portions of the territory, and by the payments made for them place Belgium

1 See especially the Chancellor's remarks in the Reichstag, November 9 , 1911 ; State Papers, civ. 969.

${ }^{2}$ Cd. 6606, p. 13. $\quad{ }^{3}$ Norddeutsche Allgemeine Zeitung, Aug. 6, 1915. 
in a favourable position to develop her remaining territory and to further the interest of Belgium itself by a reduction of the national debt. It is impossible to express any useful opinion on the character of such a proposal in the absence of those precise details which alone would give it value, but which doubtless in so incomplete and unofficial a scheme could hardly be developed, but it would obviously have been of the utmost value to Germany to secure the connexion by land between her new posts on the Congo and German East Africa, which would for ever have prevented any possibility of a British connexion between the Sudan and South Africa. ${ }^{1}$ Nor of course, at the time when it seems to have been excogitated, can the scheme be said to have been so implausible as it must now appear. The United Kingdom was engaged in an energetic effort to placate Germany by

${ }^{1}$ In his account of his mission to London Prince Lichnowsky expressly states that in the negotiations regarding the eventual partition of the Portuguese colonies ' the British Government originally intended to include the Congo State in the agreement which would have given us the right of pre-emption and enabled us to penetrate it economically. We refused this offer nominally in view of Belgian susceptibilities. Perhaps we wished to be economical of successes?' The conduct here attributed to the British Government is indeed remarkable, and, frankly speaking, incredible. In the case of the Portuguese colonies Sir E. Grey was admittedly anxious to arrive at an understanding which would be published and rid the United Kingdom of the incubus of the unhappy secret treaty of Lord Salisbury's Government. In the case of the Congo there was no motive whatever for the United Kingdom seeking to make any formal agreement of any kind, and the United Kingdom had no conceivable locus standi regarding the right of pre-emption which belonged to France, and which both France and Belgium did not desire to see in the hands of Germany. Perhaps the Prince has confused the willingness of the United Kingdom to see German enterprise establish itself in the Congo-where, in point of fact, it made in 1911-13 a desperate and not at all unsuccessful effort to oust British trade-with its readiness to abjure for its subjects in the areas of influence in the Portuguese territories marked out for Germany any commercial enterprises such as railway concessions, \&c. Mr. R. Williams lays stress on the fact that his action in obtaining from Portugal the Lobito Bay Railway concession was bitterly resented in Germany, though no British aid in obtaining it was vouchsafed him (United Empire, 1917, p. 451). 
territorial concessions-or possibilities of concession which Germany was doubtless resolved io make real-at the expense of Portugal, whose difficulties in developing her territories with her own resources are obvious and undeniable, and it is not impossible that it might have been thought reasonable to permit the connexion of the German possessions in Africa, if such a concession would really satisfy German desires for a place in the sun. France too was at that time by no means inaccessible to German proposals, and the destruction of the continuity of her possessions in Equatorial Africa might have induced her to abandon part of her territory there, especially as the intervention of the Germans between the north and the south of the colony prevented effective continuity of connexion between French West Africa and French Equatorial Africa, and rendered the possibility of constructing a railway between the northern territory and the coast, though provided for in the treaty, politically useless and commercially far from attractive. The plan, however, seems from the first to have had no serious chance of success, if it ever represented a serious expression of political opinion in any section of Belgian people.

The outbreak of hostilities in Europe found the Germans unprepared for military operations on a large scale in Central Africa, doubtless because, expecting that the United Kingdom would not take part in the war, they counted on victory in Europe securing without delay all they desired in Africa. The first move from Germany was astute: on August 4 and 5 the Acting Governor of Togoland, where the wireless station of Kamina had just been erected to secure direct communication with Berlin, proposed in telegrams addressed to M. W. Ponty, the Governor-General of French West Africa, to M. Ch. Noufflard, the Lieutenant-Governor of Dahomey, and to the officer administrating the government of the Gold Coast, that, in the interests of civilization, Togoland and the adjoining French and British colonies should be treated as neutralized. To this proposal the British replied in the negative, and the French declined to 
consider it, both Powers sending columns to which Togoland fell in the course of less than a month's campaign.' France also lost no time in recovering hęr lost territory on the Congo: by August 7 her African Alsace-Lorraine had been recovered, her troops having occupied the territory both on the Ubangi and the Congo itself.

On the same date Belgium ${ }^{2}$ made a definite move to secure, despite the violation of her neutrality at home, the recognition of the principle of neutrality which has been one of the chief aims of the Berlin Act. M. Davignon, Minister for Foreign Affairs, had already instructed the Governor-General of the Congo to stand strictly on the defensive, and he now invited the British and French Governments to consider whether they would not take advantage of the Berlin Act and declare the neutrality of their territories within the Congo basin. On August 9 the Belgian Minister at Paris reported to M. Davignon that the French Government were inclined to favour the proposal, but further reflection showed to both France and the United Kingdom the unwisdom of accepting the suggestion, and on August 17 the Comte de Lalaing definitely informed the Belgian Government that neither the British Government nor the French Government would accept the suggestion. There were obvious reasons against the proposal : fighting had already been begun in Togoland, and France had occupied German territory on the Congo ; moreover, as part of the Cameroons and of French Equatorial. Africa and the whole of Nigeria lay outside the area contemplated by the Berlin Act, the declaration of neutrality would merely have left Germany free to attack Nigeria and the Gaboon without the risk of being taken in the rear. Belgium, however, still remained on the defensive, and even the bombardment by the German steamer Hedwig von Wiss-

1 The Times History of the War, viii. 275. Cf. R. C. Hawkin, The Belgian Proposal to neutralize Central Africa during the European War (1915), and the criticism of this article by Sir H. Johnston, African World, 1915, p. 344.

2 Ibid. viii. 285 ; Jules Renken et la conquête africaine, pp. 18 sq. 
mann, on August 22, of the post of Lukuga (Albertville) on Tanganyika was not immediately followed by retaliatory action. At this juncture Germany, fearing the loss of effective communication with her African colonies by the destruction of the wireless station at Kamina which was just about to be accomplished, proposed through the United States Ambassador at Berlin that steps should be taken to place under the régime of neutrality the whole of the area contemplated in the Berlin Act, thus excluding from effective attack her most valuable territory, the East African Protectorate and the Cameroons. The motive for this suggestion, as explained by Herr Zimmermann in his note of September $15^{1}$ to Mr. Gerard, was the desire to prevent a useless aggravation of the war which would only prejudice the culture of the white race. The advantages to Germany of a proposal which would have secured for her the most important of her colonial possessions was obvious, and the refusal of the allied Governments to accept the suggestion was quite inevitable. The time indeed had come when even Belgium had to abandon the strict neutrality which she had wished to preserve. Germany accompanied her suggestions of neutralization by the march of troops to the Ubangi and the Middle Congo, which was a direct menace to the Congo territory, and on August $28 \mathrm{M}$. Fuchs, the Governor-General of the Congo, was authorized to assist the French against the German forces. On September 30, at the request of M. Merlin, Governor-General of French Equatorial Africa, Belgian troops were placed at his disposition. At the taking of N'Zimu on October $29,{ }^{2}$ and on subsequent occasions, the little Belgian force, which was finally increased to 600 men with carriers, \&c., did excellent work, and on January 28, 1916, they shared the honours of the campaign by taking part in the occupation of Yaunde on the final retirement of the German forces from the Cameroons." The German accusation that the neutrality of the Congo had been violated by the taking of Zinga on the Ubangi on

1 The Times History of the War, viii. 285.

2 Ibid. viii. 305.

\footnotetext{
3 Ibid. viii. 310.
} 
August 7 is wholly untenable: the capture of that place was effected by the French Captain Béon with a company of Senegalese operating from Bangui, while Bonga on the Congo had fallen the previous day to Leprince advancing from Brazzaville. ${ }^{1}$

The definitive entry of Belgium in Africa into the war was necessarily followed by the participation of the Congo in the long and difficult task of reducing the resistance of German East Africa, which proved to be far more formidably garrisoned than had been anticipated. Decisive success was postponed until the season of 1916, when the advent of the strong forces under General Smuts made the allied arms more than a match for the German opposition. While in the campaign from March to September General Smuts ${ }^{2}$ reduced the north-eastern parts of the territory, including the main areas of European settlement, the forces under Major-General Tombeur reduced the north-west territory. Two columns under Colonel Molitor and Colonel Olsen invaded the German Protectorate in April, following routes north and south of Lake Kivu. Thence Colonel Molitor proceeded south-east, receiving effective aid from a column dispatched by General Smuts under Brigadier-General Sir Charles Crewe, while Colonel Olsen marched down the north-eastern side of Tanganyika and, with the co-operation of Belgian gunboats and seaplanes, captured in August Ujiji and Kigoma, the terminus on the Lake of the German Central Railway. Thence the three columns, now united, marched against Tabora, the most important place in the western part of the territory, which fell to the Belgians after a considerable amount of fighting in September, while the remaining portion of the railway line from Tabora to Kilimantinde was occupied by Sir C. Crewe's column. A civil administration was created by Belgium over the occupied territory, and in December, 1916, Colonel Malfeyt, who had had experience in the government of the Congo, took up his residence in Tabora as Royal Commissioner. ${ }^{3}$

1 The Times History of the War, viii. 302.

${ }^{2}$ Ibid. xii. 77-116.

3 Ibid. xiii. 397-410. 
The Belgian campaign in East Africa, though only rendered possible by the simultaneous action of General Smuts, who diverted the attention of the overwhelming forces which otherwise would have been concentrated against the Belgian advance, was an admirable achievement. The whole force under. General Tombeur, the preparation of which took up much of 1915, amid distractions ${ }^{1}$ caused by the necessity of guarding the frontier against German aggression, was only 10,000 men organized in two brigades: it was amply supplied with transport, medical, wireless telegraphy, and supply services, and there were companies of bridge pioneers, bombers, telegraphists, and telephonists. Sixty machine guns and twelve cannon which accompanied it were magnified in the German accounts of their defeat to seventy-two cannon and 208 machine guns, ' and the German resistance, especially at the last, was pertinacious and obstinate. Invaluable aid was rendered by the naval flotilla on Tanganyika, which consisted of two British motor-boats sent out by the Admiralty in March, 1915, by the route of Capetown, and a Belgian vessel: the German vessel Kingani was captured on December 26, 1915, and the Hermann von Wissmann on February 9 of the following year, after which defeat the last German steamer, the Graf von Götzen, remained in harbour under the protection of the guns of Kigoma. Further attack on it had perforce to be postponed until the arrival in June at Tanganyika of seaplanes dispatched from England at the beginning of the year: manned by Belgian aviators, they inflicted serious damage on the Graf von Götzen on June 10, and before the end of July the vessel had been destroyed by the Germans, an inglorious end to the largest steamer ever seen on Tanganyika. ${ }^{2}$ There remained to Germany only an armed tug, which met its fate at the hands of the Belgian Netta on July 28, when the Germans surrendered Kigoma to the Belgian forces. The value of the service rendered by the

1 Ibid. x. 149, 150.

${ }^{2}$ It was 220 feet long, and was launched in 1915 ; The Times History of the War, x. 149. 
material supplied by the Admiralty is the more notable because of the enormous difficulties of transport which their arrival at Tanganyika involved. Though the line between Kabalo and Tanganyika was complete on March, 1915, the railhead on the line from Elizabethville to Bukama ${ }^{1}$ had only reached a few miles beyond the capital, and there had to be faced a journey of 150 miles of atrocious roads over hills from 2,000 to 6,000 feet high, along which traction engines could just force a painful way, when water could be found, followed by a few miles of rail to Bukama, and then 400 miles of transport down the river, whose navigation is rendered difficult by its abundance of rocks and shoals. Yet the British expedition under Commander Spicer Simson gladly sacrificed even their drinking water in order to provide the necessary sustenance for the traction engines which towed the sections of the boats in their charge.

Though the main activity of the Belgian forces ${ }^{2}$ ceased with the occupation of Tabora, further operations against the Germans being left to the British and the Portuguese, valuable aid was afforded in the minor actions arising from the efforts of Major Wintgens to revive the war within the limits of the German Protectorate, and it was to a Belgian force that this officer surrendered on May 22, 1917, being permitted by his captors to retain his sword in recognition of the valour and courtesy which distinguished him from the other German commanders whom the Belgians had had to meet in Europe and Africa. ${ }^{3}$

1 Completed in 1918.

2 The losses in the campaign of 1916 included 41 whites and 1,235 natives.

${ }^{3}$ The Times History of the War, xiii. 424. 


\section{CHAPTER XIII}

\section{THE REORGANIZATION OF THE ADMINISTRATION}

\section{The Constitutional Division of Powers.}

Under the Colonial Charter of 1908 the Congo is a Belgian Colony, with a distinct juristic personality from that of Belgium itself. ${ }^{1}$ The finance of either State is distinct, and the laws differ. The constitution of Belgium does not apply to the Congo, and the Colonial Charter which prescribes the constitution of the Colony is a simple law which can be altered by ordinary legislation in the Belgian Parliament, and in fact several amendments of the Charter have thus been made as experience has dietated. From the point of view of international law the Congo forms part of Belgium though by municipal law it is separate, and the Charter provides ${ }^{2}$ that the foreign affairs of the Congo shall be controlled by the King on the advice of the Minister for Foreign Affairs, or in effect by the Belgian Government of the day.

The supreme legislative and executive power over the Congo is vested in the King, acting, however, on the advice of the Minister of the Colonies, whose office was created after the enactment of the Charter. ${ }^{3}$ The King exercises his legislative authority by decree, and his executive power by regulations (règlements et arrêtés), subject always to any law of the Belgian Parliament which retains power to legislate on any subject for the Congo. ${ }^{4}$ He also possesses the power to remit penalties and to grant pardons. ${ }^{5}$ In the government

1 Art. 1.

${ }^{2}$ Arts. 27 and 28 . Treaties made by the King are subject to the provisions of Art. 68 of the Belgian Constitution as to parliamentary approval.

3 Arts. 9 and 23 . Every royal act must be countersigned.

4 Arts. 7 and 8.

5 Art. 20. 
of the Congo the King has the assistance of a Colonial Council of fourteen members, presided over by the Minister of Colonies, who has a deliberative and casting vote. ${ }^{1}$ Of the members eight are named by the King, three each chosen by the Senate and the Chamber : one of the King's nominees and alternately a nominee of the Senate and Chamber retires annually, but may be reappointed. No member of the Council may be a member of either house of Parliament. The duties of the Council are advisory : they may be consulted on all matters, and save in cases of urgency must be consulted before any decree is issued: their opinions must be published, and any decree passed on the ground of urgency must be laid before them. They may demand information on any topic and address recommendations to the Government.

The legislative power of the King is subjected to certain limitations; the annual budget of receipts and expenses must be approved by a law which must be presented to Parliament by October 31 in each year, but the King by arrêté may provide for the necessary operations if the law is not passed in time. Similarly, the King by arrêté, or the Governor-General by ordonnance, may order virements or provide for unforeseen expenses, subject to confirmation by law, ${ }^{2}$ and the accounts of the Colony after verification by the Court of Accounts are approved by law. ${ }^{3}$ A law is necessary for the raising or guarantee of a loan by the Colony, but the King may permit the issue of Treasylry bills of not more than five years' currency to the extent of not more than $10,000,000$ francs. ${ }^{4}$ The rules regarding concessions for railways, mining operations, grants and concessions of land must be regulated by law, the Charter providing a provisional code. ${ }^{5}$ All taxation must be imposed by a legislative act, but the Governor-General and his agents, duly authorized, may remit temporarily any native taxation. The product of

${ }^{1}$ Arts. 24 (amended by laws of March 29, 1911, and December 9, 1912), $25,26$.
${ }^{2}$ Art. 12.
3 Art. 13.
${ }^{4}$ Art. 14.
${ }^{5}$ Art. 15, modified by the law of March 5, 1912. 
customs duties and imposts is exclusively reserved for the needs of the colony. ${ }^{1}$

The Charter provides for the organization by decree of civil and military justice, but it entrusts to the Minister for the Colonies, represented in the colony by the Procurator General of the Court of Appeal, the control of the officers of the Ministère public. ${ }^{2}$ The independence of the judiciary is provided for by the rule that magistrates de carrière are appointed, either directly or after approbation not exceeding three years, for a period of ten years, after which they become entitled to pension. During that period they cannot be dismissed save on the proposal of the Procurator General, on grounds provided for by decree, with the assent of the Court of Appeal. ${ }^{3}$ The executive power is forbidden to interfere with the action of the courts, but the King, for reasons of public safety, may suspend in definite areas and for a definite time the operation of the civil courts and substitute military jurisdictions. ${ }^{4}$ Justice may be rendered in the King's name and normally in public: every judgement,must give its reasons and be pronounced in public. ${ }^{5}$

The executive power of the King is exercised in the colony by the Governor-General aided by one or more ViceGovernors-General, and the delegation of authority to persons not hierarchically subordinate is forbidden, thus excluding the use of commercial agents for official purposes. ${ }^{6}$ The delegation of the legislative power is forbidden, but the Governor-General or Vice-Governor-General in his government may suspend by ordonnance the operation of a decree or enact a new regulation, but the Ordinance shall become void if not confirmed by decree within six months. ${ }^{7}$

The Charter provides also that minors may not engage themselves for service in the Congolese forces without the

1 Art. 10, and law of March 5, 1912.

${ }^{2}$ Art. 17, interpreted by a law of May 13, 1912.

3 Art. 18, and law of March 5, 1912.

1 Art. 19. ${ }^{5}$ Art. $20 .{ }^{\circ}$ Art. 22.

7 Art. 22, modified by a law of March 29, 1911. 
permission of their parent or other guardian, and that during the period of their active service Belgian soldiers cannot accept service in the Colonial forces. ${ }^{1}$. It renders membership of Parliament incompatible with any colonial employment, ${ }^{2}$ authorizes the use of the old State flag and seal as well as the Belgian, ${ }^{3}$ provides for the execution of Belgian judgements in the Congo and vice vers,${ }^{4}$ for the continuation until altered of the laws of the State, ${ }^{5}$ and requires the presentation to Parliament with the budget of a report on the political, economic, financial, and moral condition of the territory. ${ }^{6}$

\section{The Rights of the Subject.}

By virtue of the annexation the people of the Congo, who formerly enjoyed Congolese nationality, ${ }^{7}$ by birth or naturalization, have become Belgian subjects but not Belgian citizens: the State recognizes no semi-sovereign chiefs corresponding to the native States of India. They are eligible for Belgian citizenship only on condition of naturalization, which implies residence for a considerable period in Belgium, but in the opinion of Belgian jurists ${ }^{8}$ they, as subjects, enjoy all civil rights of citizens, other than political rights proper. In the Congo there exists under the Charter ${ }^{9}$ a distinction between four classes of persons: 'Belgian citizens; foreigners who belong to a nation recognized as such by international law, and who, according to the Berlin Act, are entitled, as regards their persons and property, to the same treatment as Belgians; natives not matriculated, to whom are assimilated natives of bordering territories occupying a similar status; and natives matriculated. To all alike, however, the Charter ${ }^{10}$ accords certain liberties adapted from the Belgian Constitution: these include personal freedom, inviolability of domicile, security of property, secrecy of correspondence, the right to petition, the right to

1 Art. 34.
Arts. $29-31$.
7 C. 7830.
9 Art. 4.

2 Art. 32.

5 Art. 36.

8 Halewijck, La Charte coloniale, pp. 172-5. 10 Art. 2. 
bring actions against administrative officers, and freedom of religion and education. The freedom of the press is not guaranteed, but interference with it must be in accord with press legislation. Moreover, as a precaution against the evils of the State régime, it is expressly provided that no man may be compelled to work for the profit of another or a society. So wide declarations are obviously subject to difficulties: in the strict sense of the word the Charter would forbid any native chief compelling by penalty any of his tribe to follow their customary religion, a result certainly not contemplated by the framers of the measure, and Belgians ${ }^{1}$ have called attention to the latitude which is thought to be given by the Charter to the missionary zeal of Mohammedanism in the north-east and east, and Ethiopianism from the south, but the Charter in this regard merely reproduces the effect of the Berlin Act. The Charter ${ }^{2}$ leaves open the question of the official language of the colony save in so far as it gives Belgians the right to use in communicating with public officials either French or Flemish: the former language in fact since 1885 has been that used for official purposes in the country and is legally ${ }^{3}$ that of the Conseil supérieur. The Charter, however, contemplates that the needs of the Congolese are also to be considered and expressly requires that decrees and regulations of general interest are to be published in French and Flemish, both texts being official.

In civil rights the Charter ${ }^{4}$ draws a distinction between non-matriculated natives and other classes of the population. In the case of the latter they enjoy all the civil-in this connexion including commercial and maritime-rights recognized by the legislation of the State: questions of personal status depend on their national law if that is not contrary to public order. In their dealings with nonmatriculated natives, however, their transactions are, it seems, to be considered as regulated by custom. ${ }^{5}$ Non-

${ }^{1}$ Lannoy, L'Organisation coloniale belge, p. 56.

2 Art. 3.

3 Decree of May 4, 1891, Art. 26.

${ }^{4}$ Art. 4.

5 Lannoy, L'Organisation coloniale belge, p. 62. 
matriculated natives enjoy such civil rights as are accorded to them by legislation or custom, but subject to positive legislation and public order. Matriculation may be obtained by a native on application, and an Ordinance of the Governor-General of May 18, 1900, prescribes the automatic matriculation of all soldiers raised under the law of 1891 ; all volunteers for service of not less than two years; all children educated by philanthropic or religious bodies and residing with them; and all native servants who have served a firm for at least two years and are residing there. ${ }^{1}$ Every native matriculated must enter the name of his wife and minor children, ${ }^{2}$ and matriculation is also indirectly attained by entry of birth or marriage on the Registers of Civil Status.

As in Belgium the State is concerned to maintain control over the movements of the people, and this is accomplished by methods analogous to those in force in the metropolis. The elaborate system of registration of population is found only at Boma ${ }^{3}$ and one or two other centres of population ${ }^{4}$ : in the rest of the country a simpler system of matriculation ${ }^{5}$ takes its place, under which changes of residence have to be notified to the nearest matriculation bureau by European residents. In the case of natives-matriculated or notthere is a system of 'Recensement', ' under which each native is registered in a record kept by the territorial administrator on whom the chiefdom to which he belongs is dependent. Change of residence requires the sanction of the chief, and the native must then register himself with the division to which his new chiefdom is attached. Immigration ' into the colony is strictly regulated: any person is an immigrant who is not born in the territory or descended from such a person, or has not resided for five years, two of

1. This regulation is apparently still a dead letter for lack of arrangements to carry it out.

${ }^{2}$ Code civil, l. ii, Art. 38.

${ }^{3}$ Ordinance of April 16, 1901.

4 Applied to Matadi by Ordinance of April 19, 1909.

${ }^{5}$ Royal arrêté of March 22, 1910.

${ }^{6}$ Decree of May 2, 1910.

${ }^{7}$ Decree of March 21, 1910. 
which must be continuous. No immigrant has a right of entry if he has been convicted outside the colony of an extradictable offence; is without means of subsistence; is insane or suffers from a contagious disease ; lives by prostitution; or by his presence compromises the public order. Even if matriculated an immigrant may in any of the cases other than the two penultimate be required to leave the territory or live in a certain locality. A decree of July 5 , 1910, supplements these provisions by giving to the Governor-General, the Vice-Governors-General, and the Commissioners of Districts the right to direct the place of residence of natives in their jurisdiction who compromise the public peace. In Boma, ${ }^{1}$ in the Katanga, ${ }^{2}$ and in other centres of population ${ }^{3}$ there are in force regulations forbidding the movement of natives at night without passes, and keepers of hotels, lodging-houses, \&c., are required to keep registers of their guests, in order to secure to the public authorities means of controlling the movements of undesirable characters, of whom many have been found in the Katanga. ${ }^{4}$

Of greater importance is the restriction placed on the movements of natives in the Katanga by a pass law of March 10, 1913, which shows every sign of derivation from the pass laws of the neighbouring territory. In the areas which are from time to time determined by Ordinance, every native of Africa must on arrival present himself at the Pass Bureau, which gives him a permit of movement in the area available for three days, the permit being renewable from time to time, until the native obtains employment. When engaged the employer must secure that the employee presents himself before the expiry of his permit at the Bureau with his identity book, which is given to each native on his recensement in a chiefdom, or pass permitting him

1 Ordinance of March 11, 1910.

${ }^{2}$ Ordinance of April 15, 1912.

3 Ordinance of June 17, 1911.

4 Ordinance of May 9, 1910 (Congo); March 7, 1911 (Katanga).

${ }^{5}$ Replacing an Ordinance of October 12, 1911. 
to alter his chiefdom, ${ }^{1}$ with the contract book provided for under the law affecting the engagement of labourers, ${ }^{2}$ and with his permit, on the back of which must be endorsed the terms of his engagement. The Pass Bureau is then required to see that, if the contract is not for more than three months, the native understands its terms, or, if for more than three months, that it has been duly approved by the competent authority for the sanction of native contracts, and to enter on the native's identity book or his pass the terms of the contract, the permit of movement being then retained. On the expiry of the engagement the native must present himself at the Bureau with his documents, including a certificate from his employer of the termination of his engagement, whereupon he will be granted either a pass authorizing him to go elsewhere, or another permit of movement in the area. Both employees and employers are liable to penalties for violation of this enactment.

The same following of South Africa models is seen in the Ordinance of the Governor-General of February 10, 1913, which provides for the residence of workers and servants of colour in urban areas in special locations set aside for them. The laying out of these locations is entrusted for the capital of each district to the Commissioner, and in other parts to the territorial administrator, but in any case not more than 10 per cent. of the ground allotted may be built on, and the number of persons allowed to inhabit any building must be regulated by an allowance of five square mètres to each. The Cornmissioner of Police or the territorial administrator may forbid the entrance to any such location to any person not resident there on grounds of public order, and no white person may reside in a location without the authority of the territorial government. Servants, however, at the rate of one per European, their wives and children, may be permitted, as well as others, to reside in the European quarter.

${ }^{1}$ Granted by the territorial administrator (formerly the head of the Post) under the decree of May 2, 1910, Art. 6.

${ }^{2}$ Decree of August 17, 1910, Art. 2. 


\section{Administrative Organization.}

The final control of the administration is exercised by the Minister for the Colonies at Brussels, whose office includes, besides a Secretariat General, five Directorates General, of Justice and Education, Relations with the Local Administration, Finance, Commerce and Industry, and Agriculture. Under the Ministry fall the Colonial Museum at Tervueren, the Colonial Garden at Laeken, the Colonial School, and the School of Tropical Medicine. For advisory purposes the Minister has the Colonial Council, which, however, is rarely consulted on administrative questions, the Conseil supérieur du Congo created by a decree of April 16, 1889, which, however, has long ceased to act save as a Court of Appeal and Cassation, and the Land Commission, composed of five officials of the central administration created by arrêté of March 22, 1910, which advises on all questions affecting concessions, the sale and leasing of domain land.

In Africa the head of the administration is the GovernorGeneral, ${ }^{1}$ who exercises by ordonnance ${ }^{2}$ the executive powers of the King, subject, however, to instructions from the Minister for the Colonies. He can appoint to offices where the initial salary does not exceed 9,000 francs, and can dismiss such officers. ${ }^{3}$ He allots to officers their places of residence, and appoints provisionally to vacant posts. $\mathrm{He}$ can within limits transfer officers to different branches of the service. He determines the territorial divisions of districts and allots their personnel, ${ }^{4}$ and is in supreme command of the armed forces, ${ }^{5}$ but he has absolutely no control over the Judiciary. His legislative power is limited to enacting measures of urgency whose validity lapses in six months if not earlier confirmed by royal decree,${ }^{6}$ but this side of his functions has developed considerably with the progress of the policy of decentralization, and he has the

${ }^{1}$ Charter, Art. 21.

3 Arrêté of March 27, 1912.

5 Arrêté of May 29, 1911, and decree of November 26, 1900.

${ }^{6}$ Charter, Art. 22 ; cf. Bulletin officiel, 1913, p. 581.
${ }^{2}$ Charter, Art. 22.

4 Arrêté of March 28, 1912. 
right to enact regulations of police and public administration to which may be attached penalties not exceeding seven days' imprisonment and 200 franes fine. ${ }^{1}$ On the other hand he has no power to pardon, and may merely release provisionally from imprisonment pending the decision of the King, ${ }^{2}$ and the central government at Brussels has inherited the State tradition of constant interference in detail which diminishes the effective power of the GovernorGeneral.

The Governor-General is assisted by Vice-GovernorsGeneral, by State Inspectors who act in such capacity as he desires, a Secretary-General who is in charge of the correspondence, and seven Directors controlling the departments of Justice and Education, the Interior, Finance, Commerce and Industry, Agriculture, the Marine and Public Works, and the armed force. ${ }^{3}$ These officers, with the addition of the commandant of the forces, the Procurator General, the President of the Court of Appeal, such administrative heads as may be summoned on each occasion, and any leading citizens whom the Governor-General may desire to consult, form a Consultative Council ${ }^{4}$ which is seldom summoned or used, though its advice is necessary in the case of an expropriation of land for public purposes in case of urgency. ${ }^{5}$

At first the Belgian Government accepted the existing arrangement by which the Governor-General remained really responsible for the government of the whole territory, but a royal arrêté of March 22, 1910, created a distinct position for the Vice-Governor-General of the Katanga, under which he was to control that territory corresponding direct with the Minister for the Colonies, and only required to send a quarterly report to the Governor-General. The

${ }^{1}$ Decree of April 18, 1894, Art. 7 ; cf. Bulletin officiel, 1913, p. 780.

${ }^{2}$ Decree of December 2, 1896, and arrêté of November 13, 1897.

${ }^{3}$ Decree of October 10, 1894, and arrêté of May 29, 1911. The Charter (Art. 21) demands at least one Vice-Governor-General.

* Arrêté of May 29, 1911.

5 Decree of February 4, 1887. 
Charter was modified by a law of March 29, 1911, so as to confer on the Vice-Governor-General the right to issue legislative enactments on the same conditions as the Governor-General, and a royal arrêté of December 11, 1911, excluded the normal application of the legislative acts of the Governor-General to the Katanga. Another arrêté of December 8, 1910, entrusted to the Vice-Governor-General the control of the expenditure in the Katanga. An arrêté of March 21, 1912, assigned to the Vice-Governor-General as assistant a State Inspector or a Commissioner-General, and an arrêté of March 29, 1912, ascribed to his control the districts of Lomami, Tanganyika-Moero, the Upper Luapula and the Lulua, thus increasing the former territory of the Katanga by parts of the districts of the Aruwimi, Kasai, and Stanleyville. ${ }^{1}$ By a royal decree of November 3, 1913, the principle of devolution was further applied by the creation of an Eastern Province with capital at Stanleyville, the Vice-Governor-General being required to send copies of his ordonnances to the Governor-General, and on J.uly 28, 1914, the territory was subdivided into four provinces, CongoKasai, capital Leopoldville; Equator, capital Coquilhatville; Eastern, and Katanga, each under Vice-Governors-General. The alternative of the creation of separate colonies is not contemplated by the Charter, and the continuity of the territory presents the same arguments for the existence of a Governor-General as finally brought about the amalgamation under one head of the two Nigerias and Lagos, whose form of government presents clear affinities to that of the Congo, the Governor-General becoming a high supervising official over dependent Vice-Governments.

Throughout the country the essential basis of the administration is the district. The new régime decided to abolish the old hierarchy of district, zone, secteur, and poste, which had proved unwieldy and unworkable. It had left the responsibility of conducting relations with the chiefs to the head of the poste, who proved unequal to the burden,

${ }^{1}$ An Ordinance of February 25, 1913, of the Vice-Governor-General creates a Consultative Council, of little importance; Cd. 7048-120, p. 7 . 
while the Commissioner of the district was overburdened with clerical work, and unable to supervise effectively his subordinates. A royal arrêté of March 28, 1912, therefore increased the number of districts to twenty-two (Lower Congo, Middle Congo, Lake Leopold II, Equator, Lulonga, Bangala, Ubangi, Lower Uele, Upper Uele, Aruwimi, Stanleyville, Lowa, Ituri, Manyema, Kivu, Sankuru, Kasai, Kwango, Lomami, Tanganyika-Moero, Upper Luapula and Lulua) and substituted for the old subdivisions that of the territory. At the same time the powers of the Governor-General were increased by authorizing him to select the capital of each territory and to assign the personnel, whereas formerly only the heads of postes were designated by him. ${ }^{1}$

The Commissioner of the district is named by the King and designated by the Minister of the Colonies. He represents the Government and carries out the laws and orders which he receives from the Governor-General. ${ }^{2}$ His power was formerly limited by the fact that the heads of the secteurs and postes were not designated by him, but he now selects from the personnel allotted by the Governor-General the territorial administrators and agents for the territories in his district. ${ }^{3} \mathrm{He}$ is in control of the police, and can order military expeditions. ${ }^{4} \mathrm{He}$ accords investiture to native chiefs, and, when necessary, names and recalls them. ${ }^{5}$ $\mathrm{He}$ has the aid of a Superior Assistant in his work. The territorial administrators are his servants: they have been expressly deprived by a royal arrêté of June 25, 1912, of the right to order military expeditions or convert police measures into such expeditions, to remove villages, and to forbid or subject to conditions in a defined area the recruitment of workers. The territorial agents rank as clerks and assist in this capacity the administrators. ${ }^{6}$

It would, of course, be impossible to administer the country

1 Arrêté of March 28, 1912, Art. 3.

2 Decree of October 10, 1894, Art. 3.

3 Ibid. Art. 5.

4 Decree of June 3, 1906; he is an officer of judicial police (Decree of April 30, 1887, and Ordinance of April 22, 1899).

5 Decree of May 2, 1910.

6 Royal arrêté of June 25, 1912. 
directly by Europeans, and the essential task of the Commissioner and his subordinates is to maintain effective relations with the native tribes. The State administration, despite the decrees of October 6, 1891, and June 3, 1906, left this task unaccomplished, though some 450 chiefs had nominally been recognized, and effective organization dates from a decree of May 2, 1910. Under it the Commissioner designates in the district the different chiefdoms, including, if necessary, subchiefdoms, each of which must be dependent on a territory. He recognizes the customary chief, or, if no such chief exists, selects one after consulting the tribe: in case of misconduct he can remove the chief and substitute another. All the natives must be registered in chiefdoms, but those working for the Government or Europeans are not subjected to the control of the chief. Up to the end of 1911 over 2,700 chiefs had been formally recognized, and the number has since been raised to over 6,000 , embracing the greater part of the territory. The chiefs are sworn servants of the State, but, though they owe obedience to its officers, the chief is not subordinated to the territorial administrator, and his authority is recognized and limited, but not created, by the State. ${ }^{1}$ His power is that which the tribal custom allots to him, and it must be exercised in the customary manner, for instance, with the aid of a Council if the local practice so demands. It is, however, limited by the requirement that it must not be contrary to public order, or contravene laws or regulations intended to take the place of customary rules. The chief even within his legitimate sphere of action is subject to the control of the Commissioner, and the territorial administrator acting for him, but the policy of the Government, which desires to make use of the chiefs as means of government, tends to restrict such control to cases of action opposed to public order, the general interests of the colony or civilization, or the prestige of the Government. The decree also ascribes to the chief definite

${ }^{1} \mathrm{He}$ is paid a monthly salary, half, however, being retained until the end of the year ; the Commissioner may punish him by withholding pay up to three months. 
duties towards the State: he is required to assist in policing work, in the administration of justice, in the execution of sanitary measures, and in the performance of public works, and for these purposes maiy require monthly two days or sixteen hours' work from his people, or even longer in case of urgent works for the public safety or health. The chief is also employed in the collection of taxes, a rather dangerous power, and his right in effect to prevent the migration of his subjects has actually been abused. As intermediaries between him and the European officials are the messengers, ${ }^{1}$ who occupy a delicate position, which is unquestionably susceptible of misuse. The Commissioner may exercise measures of constraint on a disobedient chief by the use of military force.

Undoubtedly the system as developed is not without defects: the rigid rule which insists on recognizing only individual chiefs and in dividing the whole country into definite chiefdoms and subchiefdoms accords badly enough with those districts where organized chiefdoms have never existed, and the parallel of Nigeria, where for such tribes councils ${ }^{2}$ have been created in lieu of chiefdoms, suggests an alternative more likely to be fruitful in results. Nor can it be denied that the presence of matriculated natives in the chiefdoms subject to the written law must cause difficulties. Unhappily also there is little proof that the chiefs are likely to prove equal to their tasks, and the system seems likely to degenerate into a mere replica of the old system of zone and secteur with only the substitution of a chief as the head official. $^{3}$

The Civil Service ${ }^{4}$ of the colony is recruited by the Minister of the Colonies save in the case of minor offices filled by the Governor-General. Candidates selected are given a summary training at the Colonial School created by

1 Their bàdge of office is a plaque of aluminium; the chiefs wear a medal of nickel.

${ }^{2}$ Keith, West Africa, pp. 193, 194.

${ }^{3}$ Lannoy, L'Organisation coloniale belge, pp. 90-2.

4 See arrêtés of June 20, 1910, and March 27, 1912. 
an arrêté of September 30, 1910, either in the upper or lower division according to the purpose for which they are destined : those for judicial posts are trained in a special section, but in all cases the period is short. Thereafter they serve for two years on probation, and if confirmed in their posts for a period making, with the probationary period, ten years in all, deducting periods of leave. 'They are entitled to six months' leave after two years' service, and are remunerated at reasonable, if moderate, rates. ${ }^{1}$ Fifteen per cent. of their pay is withheld until retirement, or in case of death paid to their relatives, a minimum amount, however, being always allotted. After ten years' service an officer may retire on pension, or on a reduced pension after four years' service if incapacitated by ill-health. If re-engaged he draws his pension and salary and earns a second pension. The formal appointment of the higher officers is made by the King, of others by the Minister or the Governor-General, who may dismiss these officers whom they have power to appoint: the Governor-General or Minister may place them en disponibilité, or inflict minor penalties. The increase of salaries and the shortening of the tour of service have greatly improved the position of the service, but it remains difficult to secure suitable candidates for the Congo. Free passages, quarters, and medical treatment are accorded, but the practice of the State to supply food has been abandoned. ${ }^{2}$

The Belgian Constitution as amended in.1893 forbids the employment under compulsion of any Belgian in the armed force of the State, and the Charter " adds a prohibition on even the voluntary enlistment of any serving soldier. As organized by the State, and as continued in the first instance by Belgium, the force performed both military and police duties, under the supreme control of a commandant. The men are secured by voluntary recruitment, and by com-

1 From 6,000 to 50,000 francs.

${ }^{2}$ No member of the Belgian Parliament may be appointed an official below the rank of Vice-Governor-General until a year has elapsed from the cessation of his mandate (Charter, Art. 32).

${ }^{3}$ Art. 34. 
pulsory levy in numbers determined annually by a decree, ${ }^{1}$ the quota being fixed in 1913 at 3,750. The period of service is seven years with five in the reserve. ${ }^{2}$ By a decree of April 19, 1907, the total number of companies was fixed at twenty-three with a strength of about 14,000, armed as infantry and scattered throughout the country in bodies fifty strong, each commanded as far as possible by a European. The officers are all European, for the main part from the Belgian army, seconded for periods of service. ${ }^{3}$ In 1910 a recommendation was made that the functions of military and police were inconsistent, and this recommendation has now been carried into effect by the division of the force into the army proper, consisting of some 12,000 men fully organized for war purposes, and a police force about 6,000 strong.

${ }^{1}$ See Charter, Art. 16 ; decree of July 30, 1891 : in case of necessity all servants of the State, save judicial officers, may be called upon to serve; decree of November 26, 1900, Art. 19.

${ }^{2}$ Arrêté of January 18, 1898. Discipline rests on a decree of July 31, 1912.

${ }^{3}$ Charter, Art. 33. Their position depends on an arrêté of March 27, 1912, and a decree of June 25, 1912. All the officers are named and dismissed by the King; State officials by the Minister for the Colonies or the Governor-General. Of the sub-officers some are European, some native. In 1918 there were 355 white officers and sub-officers. 


\section{CHAPTER XIV}

\section{THE JUDICIARY AND THE FINANCES}

\section{The Judiciary.}

The judicial system of the State was plainly inadequate to the needs of the territory, as was recognized by the reform decree of 1906, but it was not until 1913 that, after much consideration of the difficulties intervening, it was found possible by the Colonial Council to produce a definite measure, enacted as a decree on August 13, 1913, dealing with the tribunals and their competence. ${ }^{1}$ The status of the judicial service had been regulated a year before by a decree of August 20, 1912. The problem which presented itself to the Council was how to -secure effective justice without endangering the observance of principles of equity. The traditional doctrine of the separation between the executive and the judicial powers had rendered the State unwilling to confer on executive officials any judicial authority, and the difficulty of doing so was obvious when the comparatively inferior training and character of the administrative officers was taken into account. These considerations explain why, even in the law of 1913, the judicial functions ascribed to executive officers are of very minor importance in comparison with those assigned to officers of similar standing in the British colonies and protectorates, a system which has admittedly furthered the interests of the administration and of justice in equal measure.

Under the new régime the territorial administrator sits as a Police Court with power to take cognizance of all offences punishable with a maximum of seven days' im-

1 The system prevailing before this decree is described by Lannoy, L'Organisation coloniale belge, pp. 109 sq. 
prisonment or 200 francs fine by natives, matriculated or not, of the Congo and the bordering countries. They may deal also with more serious offences if they consider that. the circumstances in each case render a penalty of 200 francs and seven days' imprisonment adequate. They may also deal with offences by non-natives where the maximum punishment does not exceed 200 francs and seven days, if they consider that a fine will be sufficient penalty. In no case can the imprisonment inflicted in lieu of a fine exceed seven days, so that even a native cannot suffer more than fourteen days' imprisonment under a sentence of a Police Court. All the sentences are subject to revision by the Court of the Public Prosecutor, which may annul them, but. they are not subject to appeal. There is, however, an exception to this rule in the case of urban localities in which the Court is held by a magistrate de carrière, in which case an appeal lies to the Court of the Public Prosecutor.

The Court of the Public Prosecutor deals with all offences by natives, its sentences taking immediate effect if they do not exceed 200 francs and seven days' imprisonment, and all offences committed by non-natives if the penalty does not exceed five years' imprisonment or is a fine. The Court may, however, send to a Police Court for disposal any case whatever in which it thinks that a fine of fifty francs and imprisonment for seven days is a sufficient punishment. This Court consists of a judge, the Royal Procurator, and a registrar.

The Court of First Instance, seven of which were instituted in 1910, composed of a judge, an officer of the Public Prosecutor, and a registrar, deals with offences committed by non-natives punishable by over five years' imprisonment, and with charges against territorial administrators and officers of superior rank. On appeal it hears cases from the Court of the Public Prosecutor and magistrates in urban areas. When sitting in this capacity it must be assisted by two assessors chosen from magistrates de carrière or notables in the area if the appeal concerns an offence punishable by over five years' imprisonment in the case of a native or over 
six months' imprisonment in the case of a non-native. The assessors have a deliberative vote.

The Courts of Appeal, ${ }^{1}$ consisting of a president, two judges, an officer of the Public Prosecutor, and a registrar, hear appeals from Courts of First Instance and alone can deal with accusations against magistrates de carrière.

Beside these civil courts there exist Councils of War, consisting of a judge, an officer nominated by the GovernorGeneral, with the usual officials and Appellate Councils of War, presided over by the judge of the local Court of First Instance, aided by two officers of the armed forces. These courts deal with all offences of the officers, sub-officers, and men of the armed forces.

In civil cases the courts of the Public Prosecutor decide finally on all cases, where the value in dispute does not exceed 100 francs; in cases up to 600 francs they decide subject to appeal. Courts of First Instance hear appeals from these courts, and may hear and dispose finally of any case where the value does not exceed 2,500 francs, and hear in the first instance all other cases, civil and commercial. They alone deal with foreign judgements, and though administrative matters generally are still deliberately withheld from their competence, in accordance with the doctrine of the separation of powers, fiscal matters are excepted generally from this exclusion. ${ }^{2}$ From their decisions an appeal lies to the appeal tribunals.

This imposing edifice is capped by the Conseil supérieur du Congo at Brussels. As a court of cassation it deals with all civil and commercial judgements of the courts below : as a court of appeal it hears appeals from decisions of the Courts of Appeal where the value at stake exceeds 25,000 francs, and in criminal matters appeals in the case of magistrates, while as a court of first instance ${ }^{3}$ it deals with charges against judges of the Courts of Appeal and officers of the Public Prosecutor.

The duty of securing the due observance of the law and

1 At Boma and Elizabethville. ${ }^{2}$ Art. 84.

\footnotetext{
${ }^{3}$ Decree of October 8, 1890.
} 


\section{THE JUDICIARY AND THE FINANCES}

the prosecution of offenders rests with the ProcuratorGeneral, the head of the Ministère public, who is subject not to the Governor-General but to the Minister for the Colonies. ${ }^{1} \mathrm{He}$ has under him a large staff, a royal procurator being attached to each court, and he has also the assistance of the officers of judicial police, including all the chief administrative officers. The police force proper is dependent on the Governor-General ${ }^{2}$ : it is divided into divisions, one of which is ascribed to each district and placed under the supreme control of the commissioner, aided by a commissioner of police. The division is subdivided into brigades commanded by a sub-commissioner or other official. The prison régime for those sentenced to this penalty distinguishes between white and native, and has been the object of much consideration by the Government with a view to securing the greatest measure of humanity consistent with effective deterrent force.

The officers of the Public Prosecutor and the judges alike are classed as magistrates de carrière, and treated in an exceptional manner from the rest of the service of the State. They must be doctors in law, and in pay and pension alike they are more highly remunerated than other officials, from whom they are distinguished by an unusual degree of security of tenure, as, once definitely appointed, they can be removed only by the King on the proposal of the Procurator-General and with the unanimous advice of the Court of Appeal. ${ }^{3}$ Neither solicitors nor barristers are yet necessary features of a case, but each court appoints its own officers, while notarial functions, are usually assigned to officers of the Prosecutor.

Beside this complete system of justice, which applies to every inhabitant of the territory, native or non-native, there exists a humbler native jurisdiction. Under. the Penal

${ }^{1}$ Charter, Art. 17, interpreted by a law of May 13, 1912.

${ }^{2}$ Ordinance of January 1, 1912 ; for the Katanga Ordinances of September 20, 1911, and November 27, 1912.

${ }^{3}$ Charter, Art. 18, modified by a law of March 5, 1912. Their status is regulated by the decree of August 20, 1912. 
Code of the State the competence in criminal matters normally lay with the European court alone, but the Public Prosecutor might hand over the case to the chief: under the decree of May 2, 1910, a crime committed by a native, even if matriculated, is normally judged by the chief of the place where it is committed ${ }^{1}$ unless the representative of the Public Prosecutor prefers to bring it before a European court. The chief exercises as judge the power allowed to him by custom, but subject to two limitations : the only corporal penalty which may be imposed is a flogging, not exceeding twelve strokes, and women, children, old men, and invalids are exempt from this; he must also notify to the European authorities any cases of poison ordeal, cannibalism, human sacrifice, slave-trading, or the growth, sale, traffic in or use of hemp, so that they may be punished by a European court, since none of these offences are crimes by native law. No appeal lies to a European court, but, if custom prescribes, it may be taken to the court of a superior chief. On the other hand, a European court may always hear de novo any case in which a defendant in a native court feels aggrieved by the judgement, in which event the proceedings in that court are regarded as null and void. ${ }^{2}$

In civil matters natives may always have recourse to European courts, but the chief has the right to hear cases between non-matriculated natives which they bring before him, though the defendant in such a case may always decline his jurisdiction. ${ }^{3}$ His decision is not susceptible of appeal to a European court. It does not appear ${ }^{4}$ that a chief is entitled to hear a case between a European or matriculated native and a non-native, even if the case

${ }^{1}$ Code pénal, Art. 84, as interpreted by Lannoy (L'Organisation coloniale belge, p. 279), who justly points out that this may involve injus. tice, as a man may thus be tried by a law not his own.

2 Decree of May 2, 1910, Art. 19.

${ }^{3}$ Cf. decree of August 11, 1913, Arts. 81-3.

${ }^{4}$ Lannoy, L'Organisation coloniale belge, p. 114, takes a different view, but the report of the Colonial Council on the decree of August 11, 1913, seems to preclude this opinion. 
should be decided by customary law. On the other hand, the European courts are clearly bound in all dealings between non-matriculated natives to apply customary law, unless contrary to positive enactment or public order, and possibly they should apply such law to cases of agreements between-non-natives and matriculated natives on the one hand and natives on the other.

\section{The Finances.}

The Charter ${ }^{1}$ provides for the financial separation of Belgium and her colony, but in the discussion of the Colonial Law the Premier undertook, in order not to make a distinction between the office of Minister for the Colonies and other Cabinet ministers, that the cost of the central establishment should be borne by Belgium, and this reform has been consistently applied, extending, however, merely to the Ministry proper and not to its adjuncts, such as the Tervueren Museum. The Charter ${ }^{2}$ gives also to the central administration the control of the budget, which must be voted by Parliament, and this derogates seriously from the effectiveness of the power of the local government. As presented to Parliament, the budget includes a statement of receipts, one of normal expenditure, one of expenditure of an extraordinary kind to be met out of loans, and a statement of expenses and receipts. Since the creation of the Katanga and the other Vice-Governments-General, the plan has been adopted of distinguishing a general and local budgets, on the model of the French possessions in West and Equatorial Africa: the former includes the receipts from customs, the post office, and justice, and the expenses on these services; the latter the local revenue and expenditure of the different parts of the territory. The Charter, however, accords to the King the right to continue expenditure pending the voting of the budget, if that is not passed by December 26, for periods of three months at a time. Virements and supplementary expenditure may be autho-

1 Art. 1.

${ }^{2}$ Art. 12, modified by a law of March 5, 1912. 
rized by the King or the Governor-General, but must be approved by a law. The due expenditure of the public funds and the collection of the revenue are provided for by an elaborate system which is subject to the final supervision of the Cour des Comptes at Brussels, which examines the colonial accounts and reports on them to the legislature, which finally approves them by a law.

The change in the policy of the State is reflected in the complete alteration in the nature of its resources. Out of a revenue of 35 million francs in 190816 millions represented products of the domain, tributes and imposts paid in kind, and even in 191110 millions came from this source. From its lands the State draws now much inferior revenues, derived from sales and leases, dues on licences to collect rubber, \&c., the ivory tax, dues for cutting wood in domain forests, from which natives or persons cutting for domestic use are exempt; and until $1913^{1}$ taxes on rubber destined to produce a fund for replantation. Revenues are also derived from posts and telegraphs, river transport, government plantations, and - a very important item-mines. The State is still also interested in various companies, but its revenues, over three millions in 1911, have become almost negligible with the surrender of its interests in the Abir, the Société anversoise, and the Kasai Company. Fees for services rendered include judicial fees, pilot and harbour dues, survey fees, registration fees, dues on permits to have arms, dues for custody in bonded warehouses, and a statistical $\operatorname{tax}$.

Taxation proper includes a personal tax ${ }^{2}$ which is paid mainly by non-natives but applied also to natives who have industrial establishments employing at least one worker: the tax is based on the size of the building, the number of employées, and the number of boats used. Traders, ${ }^{3}$ who are not subject to this tax, pay a duty of 200 francs annually,

1 A decree of August 20, 1913, consolidated all rubber taxation into an export duty varying with the value of the product, and exempting plantation rubier from tax.

2 Decree of March 17, 1910.

${ }^{3}$ Decree of March 22, 1910. 
or 500 francs if they trade in rubber, copal, or ivory. Natives pay a head tax, now fixed at from two to twentyfive francs for each adult male, with an addition of two francs for each wife, after the first, up to thirty. Chiefs, soldiers, natives paying the personal or trading tax, or having three children by a single wife, or disabled by illness for six months are wholly exempt, and the tax may be lowered or withdrawn for any locality. The chief or subchief may be used to collect it under precautions to secure fair treatment; if a native does not pay, the chief may apply native means of compulsion, and if the native is not subject to a chief his goods may be seized and he becomes liable to a fine of thirty francs or two months' imprisonment in lieu. ${ }^{1}$ The tax can only be paid in coin, an arrangement destined to avoid the abuses of the Congolese régime, but one which has of late been represented to be inconvenient as rendering collection difficult. The reintroduction of the old régime, however, could hardly fail to revive the old abuses. A tax of 2 per cent. is levied on the profits of companies, one of 4 per cent. on sums awarded in civil cases, and a tax is exacted for permission to hunt elephants.

Customs duties, comparatively negligible under the State régime, have largely increased in importance: in accord with the Brussels Act they average 10 per cent. ad valorem save for alcohol, but the use of liquor has been prohibited to natives, even in the Lower Congo, since 1913. Export duties are specific, not ad valorem, and are fairly high; rubber paid in addition a tax of 75 cents and 50 cents a kilo on tree and grass rubber respectively, but by a decree of August 20,1913, all rubber taxation was consolidated as an export duty.

The effect of the war has inevitably enormously reduced the receipts of the State, which were in $191245,367,639$ francs, in $191340,418,100$ francs, in 1914 30,457,276 francs, in $191530,451,250$ francs, and in $191632,099,082$ francs. In this year the mines yielded 7,000,000 francs, the native tax 9,500,000 francs, and customs 6,000,000 francs, these three

${ }^{1}$ Decree of May 2, 1910. 
heads constituting the sources whence increase of revenue can fairly be expected.

The expenditure since annexation had always exceeded the revenue, and the accounts have been balanced by loans. The total expenditure for 1912 was $66,538,970$ francs, in $191365,957,081$ francs, in $191463,076,573$ francs; in 1915 the ordinary expenditure was $51,936,000$ francs, and in 1916 $54,755,912$ francs. ${ }^{1}$

The public debt of the State includes the loans of the Independent State, ${ }^{2}$ the fifty million francs provided for by the additional act of cession, and the new loans incurred by the State. In 1913 the debt had attained 313,547,200 francs, including $69,545,000$ of floating debt, and the interest had risen to $9,673,035$ francs. This is a serious figure, and the large deficits of recent years are undoubtedly hampering the progress of the territory. Part, however, of the decline of revenue may be ascribed to temporary causes, especially the fall in the value of rubber, and the natural increase in the products of the domain, and the mineral royalties, the growth of native taxation with the extension of effective occupation, the increase of the tax with the growth in the wealth of the natives, and the increase in customs dues, which is certain to be the result of the rise in the standard of living of the natives, afford reasonable ground for confidence in the ability of the country to bear its burden of debt. In the long run also, it may be fairly argued that Belgium might reasonably accept the duty of assisting the State if that became essential, for the.profits which Belgium derives from the Congo have been large in the past and may easily be considerable in the future.

Belgium has solved in a satisfactory manner the currency question, which the State had left practically untouched. The small amount of State currency in circulation was

1 The central government is unduly expensive, costing 2,170,006 francs in 1913. This feature was noted by Mr. Pickersgill in 1898.

${ }^{2}$ See a list in Masoin, Histoire, ii. 414. The lottery loan of 1887 is nominally secured by the funds provided by the State, but these are insufficient. 
demonetized from October 1, 1909, though accepted in payment of taxes up to July 1, 1913. In its place Belgian currency ${ }^{1}$ has been substituted, nearly twenty-five million francs worth having been introduced by August 1, 1912. Moreover, the Bank of the Belgian Congo, a private bank but under agreement with the State; has authority to issue notes up to ten million francs, the profits of which it shares with the State. The use of currency has been encouraged effectively by the rule of the State since January 1, 1912, to pay its workers in currency, and by the requirement since 1910 that all native taxation must be paid in cash.

1 The Charter by Art. 11 gives it validity in the Congo and assigns profits on coinage, struck for the Colony, to the colonial revenues. It permits the use of a special coinage, not valid in Belgium, such as has been created in British West Africa. (Cf. Keith, West Africa, pp. 243 sq.) 


\section{CHAPTER XV}

\section{THE LAND RÉGIME}

\section{Native Land Rights.}

THE sovereignty of the State rested upon the acquisition from native chiefs of a large number of treaties, the terms of which were far from uniform. ${ }^{1}$ But in the land policy of the State from the outset there appears to have been no effort made to deal separately with the tribes: the land question was treated as on a single basis, and the land rights of the State were, it appears, deemed to flow directly from its sovereignty irrespective of the precise terms of the treaty, applicable to any particular section of the country. ${ }^{2}$ The aim of the Association in negotiating its treaties appears, however, clearly enough from the terms of such a treaty as that with the chiefs of Ngombi and Mefela concluded by Stanley on April 1, 1884. The chiefs, claiming to be the absolute owners of the country ceded by them, and to be acting with the unanimous assent of the people, agreed that the Association should become possessed in absolute property of all roads and waterways, rights of collecting tolls on these roads and waterways, and of all game, fishing, mining and forest rights, 'together with any unoccupied lands as may at any time hereafter be chosen'. At the same time the Association undertook ' to take from the natives of the ceded country no occupied or cultivated lands except by mutual agreement', and in another treaty of April 19, 1884, with the chiefs of Pallaballa it was expressly provided that the expression 'cession of territory', which had been used in

1 See Stanley, The Congo, ii. 197-206.

${ }^{2}$ Lannoy, L'Organisation coloniale belge, p. 135. 
the earlier treaty with the chiefs of January 8, 1883, did not mean the purchase of the soil by the Association but the purchase of the suzerainty.

The State in its Ordinance of July 1, 1885, issued by the Administrator-General of the Congo adopted the position that ' Nul n'a le droit de déposséder les indigènes des terres qu'ils occupent', and on the other hand that all vacant land was the property of the State. The policy embodied in this measure assumed that there was to be found in the Congo a distinction between territory actually in the occupation of natives, and other lands over which the native tribes might have a political claim but which they did not occupy, and which therefore might properly be assumed to pass to the sovereign power in the Congo, or over which no tribe had even a political claim. The last possibility at the time of occupation of the Congo could hardly have had much application $^{1}$ : the native tribes appear to have had very definite ideas of their boundaries, though these might by wars be varied from time to time, and the land claimed by the State must therefore rather have fallen under the category of parts of the tribal territory not actually occupied. ${ }^{2}$ But the meaning of the term occupation, as has been seen, was not made clear until the reform decree of June 3, 1906, which still governs the situation. Under it the term 'occupied' includes 'toutes les terres que ces derniers (les indigènes) habitent, cultivent, ou exploitent d'une manière quelconque'. The terms are to be understood as interpreted by the local practice of the tribes, and therefore the collection of the natural fruits of the soil is included as occupation. In order, further, to permit of rotation of crops the decree prescribes the assignment to each village of three times the area inhabited or occupied by it, or even more, with the per-

${ }^{1}$ Johnston (George Grenfell, i. 456) seems to suggest that some parts were not even under political sovereignty, and that in any case there was much unoccupied land which the State could justly claim, if it were ready to use it for public ends.

2 This is the view taken by Lannoy, L'Organisation coloniale belge, - p. 143. 
mission in the latter case of the King. The delimitation thus accomplished in each case is depicted on an outline map deposited with the Commissioner of the district, and is marked out on the spot by natural or other boundaries.

It follows clearly from the manner in which the decree has been applied that the recognition of native occupation is not extended in the full breadth of the actual terms of the decree: under these terms it would seem that all the extent of the territory which the natives ever used, e.g. for collecting rubber or ivory, should be treated as native land, for they certainly 'exploitent d'une manière quelconque' such territory. The official interpretation, however, limits the intention, and in effect assigns to the village an area three times the amount of the land under occupation in a more intensive sense at the time when the delimitation is made, leaving it for future legislation to extend these areas to meet new growth of population.

The State also proceeded to interpret in a peculiarly narrow sense the extent of the native rights in the land which they occupied. It is perfectly clear from the terms of the treaties that the natives who gave sovereign rights to the Association claimed to be absolute proprietors of the lands, the sovereignty of which they conveyed, and in the earliest enactments of the State regarding the registration of title acquired from the natives, which was forbidden unless the contract of 'l'acquisition ou la location' was approved by the Governor-General, the terminology proves clearly that the State recognized the natives as absolute owners of their lands. ${ }^{1}$ Shortly after this, however, the State adopted a wholly inconsistent and illegal attitude, for in the first place it decided that the natives had only the right of user of their lands, ${ }^{2}$ and, in the second place, that they could only dispose of the products of their lands in the measure in which they had done so before the constitution

${ }^{1}$ Decree of September 14, 1886, Art. 2 ; Ordinance of November 8, 1886, Art. 1.

${ }^{2}$ Codification des dispositions concernant le régime foncier, novembre 1893, Art. 1. 
of the State. ${ }^{1}$ In the reform decree of June 3, 1906, the native rights appeared in a definitely reduced form: 'Il sera procédé à la détermination officielle de la nature des droits d'occupation des indigènes.' The apparent sense ${ }^{2}$ of this prescription would be that the administration was charged with the duty of determining the nature of the rights which arose from the occupation by the natives of the land, so that it could decide whether it was to regard them as proprietors, commoners, holders precario or so forth, but it was also possible to regard it as meaning that the duty of the State was to determine whether the occupation was permanent, temporary, complete, or limited to some purpose or other. In the latter case the position of the natives would be treated as a mere right of enjoyment of the soil, the domain resting in the State, a position which offers a remarkable parallel with that of the American Indians in Canada as defined by the Privy Council. ${ }^{3}$ The point, however, has not been decided by any legislation of the Congo, and is of more theoretic than practical interest. What is clear is that, while the natives have the enjoyment of the areas allotted to them, they cannot dispose of them to third parties without the assent of the administration, which in view of the restricted nature of native lands can hardly ever be properly accorded.

\section{The Domain Lands.}

The State, and now the Colony, possessed domain lands of two classes. The first, of very minor importance, comprises those lands which have been expropriated for public purposes in virtue of the decree of February 4,1887 , supplemented by a ministerial arrêté of February 28, under which, in default of agreement between the Government and the owner of the land, the compensation is decided by a tribunal : under the

1 Rapport de la Commission d'énquête, p. 151.

${ }^{2}$ Lannoy, L'Organisation coloniale belge, pp. 140, 141.

${ }^{3}$ Keith, Responsible Government in the Dominions, ii. 683-7. 
Colonial Charter ${ }^{1}$ the old rule which permitted the price to be paid within four months after the decree of expropriation has been supplanted by the Belgian rule requiring payment to be made in advance.

The vast bulk of the domain consists of the lands claimed by the State as vacant. It again falls into two categories, the first constituting the public domain, and the second the private domain in the more strict terminology. The former includes rivers, streams, and watercourses which are navigable or not, and the borders to an extent of ten metres from high-water mark; which are open to -public passage ${ }^{2}$ : curiously enough, the same rule has not been made applicable as in Belgium to the foreshore, ports, harbours, and roadsteads, though in the Congo it affects the beds and the margin $^{3}$ of the Great Lakes, which are subject to frequent variation of depth.

The rest of the domain is the private domain, which is open to disposal by the State. ${ }^{4}$ No principles are laid down in the Colonial Charter regarding the extent to which cession or concession of this domain should be approved, but the control over the land is reserved strictly in the hands of the Belgian Government. In its original form the Charter ${ }^{5}$ required that every cession or concession of domain lands, whatever the period of concession, must be approved by a decree if the area affected was over ten hectares, but the unnecessary rigour of this requirement has been reduced by a law of March 5, 1912, under which the intervention of a decree is requisite only for cessions or concessions for any period of lands outside urban areas exceeding 500 hectares, and of lands in urban areas exceeding ten hectares. Moreover, in order to secure the full control of Parliament over important transactions, there must be laid before both

1 Art. 2.

${ }^{2}$ Decree of August 9, 1893, Art. 7 ; amended by decree of June 30, 1913.

s Decree of June 30, 1912.

4 This was asserted in the decree of June 30, 1887, and now under the decree of February 23, 1910.

b Art. 15. 
houses for thirty days drafts of any decrees proposing to approve cessions of the domain of over 10,000 hectares, and concessions of over 25,000 hectares if for more than thirty years. All railway and mining concessions must be made by decree, and submitted to Parliament, whatever their nature. Moreover, in order to prevent evasions of the spirit of the law, the provisions as to area are reckoned in connexion with any other land ceded or conceded previously to the person concerned, unless the new cession or concession is one of an area not exceeding two hectares.

The policy of the State refused to grant concessions of land save to companies in which it had the controlling voice, and the acquisition of any substantial area outside an established station was, in the latter years of the régime, practically impossible, whatever the purpose for which land was desired. The natives had no land which they could sell, and, even if they desired to do so, required the permission which the State would not grant, and the State denied that it was under any obligation to part with its own lands. The new régime has reversed this policy and has opened the lands to acquisition by third parties on fair terms. These are determined by an arrêté of the King of February 23, 1910, followed by an Ordinance of June 19, and though these instruments can refer only to the transactions within the power of the Governor-General, the Government have observed the principles in general in the special decrees issued, such as that of April 29, 1911, approving the agreement with Messrs. Lever. The Minister for the Colonies fixes the areas in which sale or lease is permissible; application must be made to the GovernorGeneral, who decides the matter. Leases may only be for fifteen years, and the owner or lessee of any property must enter upon occupation within six months or the agreement is void. He must also establish himself, or a person matriculated in the colony, on the land on pain of forfeiture of a holding of land purchased by five years' absence and of one leased by one year's absence. The price of the land sold varies according to locality, and in the case of larger areas 
a scheme of provisional occupation before final purchase or lease has been devised.

In the Katanga the Comité spécial, in accordance with the agreement of 1900, is charged with the duty of land grants and leases, and acts under rules published on May 1, 1910. It is, of course, bound by the terms of the Charter, but the power of the State in this case extends only to approval or disapproval of the proposals of the Comité. The terms of land grants in this part of the territory are subjected to the right of entry by representatives of the Comité to prospect on the land and to its right to take back the whole or part of the territory on payment of compensation. Both in the Katanga and the rest of the Congo the rule of the Charter requires that every concession must be for a definite period, and must contain clauses providing for repurchase, and for the case of avoidance of the concession. ${ }^{1}$

There remains, of course, a vast area of the domain land which is still neither ceded nor conceded to private individuals or companies, and it is to these areas that the decree of March 22, 1910, ${ }^{2}$ restoring freedom of trade, is applicable. That decree makes it plain that the free right to collect domain produce is subject to exception in the case of $(a)$ territory leased by the State; (b) territory occupied by State plantations; and $(c)$ territory in respect of which either by express agreement with the Government or by usage third parties possess special rights, as, for instance, in cases where natives have enjoyed the privilege of exploitation. The effect of the decree has been enormously increased by the agreements with the Abir, the Société anversoise, the Société internationale forestière et minière, the Kasai Company, \&c. In the area set free natives may freely collect the produce without a special permit unless they directly export it, in which case they are put in the same position as non-natives. The latter must have a permit for themselves or their factories if they collect the produce, whether directiy or through natives, or purchase it, and a permit costs 250 francs if either rubber or copal is 1 Art. 15.

${ }^{2}$ Above, Chap. XI. 
collected; the permit is available for a year from January 1 or July 1. In order to provide for the replanting of the rubber. areas there was imposed by a decree of December 3, 1909, a tax of 40 cents per kilogramme on tree rubber and half that amount on grass rubber collected in the domain, ${ }^{1}$ and by the decree of March 22, 1910, the State reserved for itself five forest reserves of an area of 600,000 hectares in order to produce rubber from government plantations on a large scale, a policy since modified. ${ }^{2}$

The position of the domain forests is dealt with by a decree of July 4, 1912, which is in general accord with the legislation of the State. Under it any person legally established on the Congo territory is entitled, without a permit, to cut or purchase from the natives firewood for domestic use; for any other purpose a permit is needed, which costs in the case of a boat 250 to 50 francs, according as the net tonnage exceeds ten tons or not, and in any other case 1,000 francs a year. Natives who do not pay the personal tax levied on owners of establishments can cut freely for any purpose, and even those who pay that tax may do so if they cut for their own use only or for sale, or if they have not more than three workers in their employment. If wood is required for constructional purposes natives may cut it without stint; other persons require the permission of the Commissioner of the district, and must. pay five francs a cubic metre for any wood required for other than the purposes of their establishments. The preservation of the forests is provided for by various regulations, and the setting aside of reserves has been arranged.

The right of hunting over the domain is freely granted to the natives, a proposal in 1910 to exact payment for the privilege having been abandoned on the advice of the Minister for the Colonies.

1 By decree of August 20,1913, this tax was merged in a single export duty on rubber.

2 Cd. 6606, p. 114. 


\section{Registered Lands.}

The third category of lands in the colony is provided by lands which are held as private property by individuals or corporate bodies in absolute ownership. Such lands include those which before the establishment of the State had been acquired-by whatever means - by private persons, lands ceded by the domain, and lands acquired with the permission of the State from native holders, the.last a comparatively unimportant class. All private lands must be registered ${ }^{1}$ on a system which is copied fairly closely from the Torrens system adopted in South Australia by the law of July 2, 1858, and since then widely extended. Under the Ordinance of November 8, 1886, each title, with all the attendant. burdens, must be entẹred in a register, and the owner has handed to him in exchange a certificate of registration. The dimensions of each property are formally recorded after survey, and all transactions regarding registered land must be duly registered. The registers of the colony are kept at Boma and Elizabethville. It is expressly provided that, though not entered on the register, the properties remain subject to any rights which by custom the natives may possess in respect of the land, and no provision exists for the extinction of these rights, which obviously must be preserved in the interest of the communities of natives as wholes.

The legislation of the period $188 \overline{\mathbf{s}}-\mathbf{7}$ did not contemplate the registration of any person save a non-native as owner of land, but the result of the terms of the Civil Code ${ }^{2}$ and of the Charter ${ }^{3}$ is to confer the same right on matriculated natives. Not only, however, is the number of such natives very limited, but, as no free grants of land to individuals

1 Ordinances of Novemiber 8, 1886, and February 23, 1906; Lannoy, L'Organisation coloniale belge, pp. 136-8.

2 Bk. ii, Art. 6. (The Civil Code of the Congo is a collection of decrees on Civil Law, not a single Code.)

3 Art. 4 ; above, p. 179. 
are made normally by the colony, the acquisition of land in private property and by a native presupposes the possession by him of relatively large sums of money, for the State recognizes in native land nothing but collective owuership or right of occupation, and provides no means for the conversion of this into private property. The State, indeed, has readily expressed its willingness to transfer parts of the domain lands to bodies of natives gratis for the purpose of cultivation in their own interest, ${ }^{1}$ but it has carefully refrained from making any such offer to individual natives.

The growth of private property in the territory of the Congo, overwhelmingly in non-native hands, raises a fundamental question which has not yet been solved by the State. The lands which have been allotted to the native villages are clearly certain in course of time, with the increase of population produced by the Pax Belgica, to become far inferior to the needs of the natives, and there will then arise the problem of a native population unable to find its living on the area which it possesses. To what extent should the State determine, before the problem has become acute, to reserve the remaining domain lands for native use? Can the policy of alienating the domain to nonnatives without definite consideration of future native needs be defended on the ground that it will drive the natives to work, and that work is the best means of regenerating him? In parts of South Africa the question is already a pressing one, and it is one which in any case will have sooner or later to be faced by every Central African administration. ${ }^{2}$ So far the Belgian Government has not intimated any definite decision as to its attitude in this regard. It is, however, possible to read a satisfactory solution of this question into the announcements which were made by representatives of the Belgian Government in June, 1912. The Belgian Minister, in a conversation,

${ }^{1}$ Cd. 6606, p. 41 (M. Davignon's note of July 3, 1912).

2 The British West African territories have definitely abstained from efforts to divert the land from native use. 
reported by Sir Edward Grey, ${ }^{1}$ on June 22 referred to the decree of March 22, 1910, as recognizing the irrevocable right of the natives to gather the products of domainal, i.e. vacant lands, and gave an assurance that the colonial government 'desired to see vacant lands brought to the greatest possible extent under native cultivation'. Lands granted to natives for this purpose would form parts of those occupied by the tribes and fall under their customary law, enjoying the same guarantees as applied to the lands under native cultivation, and every attempt to interest the natives in the development of cultivation would be received with satisfaction. Even more important is the statement made by M. Renkin ${ }^{2}$ on July 29, 1912, to the members of the International Colonial Institute at Brussels. He then defended the land policy of the colony as necessary to secure progress, which would be impossible if the land were left to acquisition by the first comer, and stated that in practice the native lands were not delimited save where the proximity of private property rendered such a course necessary. He strongly repudiated what he admitted to be the current idea that the State held that vacant lands could only be assigned to colonists or commercial undertakings to the exclusion of the natives. The grant of land to Belgian colonists and to commercial, industrial, and agricultural enterprises he held to be a necessary preliminary to the introduction of civilization, the production of labour, the circulation of money, and the instigation of the native to rise in the social scale. 'But vacant lands can,' he added, 'and, if our hopes are realized, will, be granted to natives in what we trust will be important proportions. If groups of natives or individuals, encouraged by European traders or agriculturists, should desire to undertake productive cultivation, the Government would be happy to help them by making them grants of vacant land. Far from ever having dreamt of restricting native activity to the primitive cultivation of their reserves-an attitude which would be

${ }_{1}^{1}$ Cd. 6606, p. 39 ; repeated by M. Davignon, July 3 (ibid. p. 41).

${ }^{2}$ Cd. 6606, pp. 48, 49. 
nothing less than absurd-the Government ardently look forward to the day when it will be possible for them to make liberal grants of fresh lands to those natives who undertake to make them productive.' It is noteworthy that M. Renkin refers to applications from individual natives, a reference contained neither in the Comte de Lalaings communication nor in that of M. Davignon, and the allusion to encouragement by European traders and agriculturists introduces a new element, which, however, unlike the reference to individuals, is not inconsistent with the earlier announcements. The reconciliation of the two statements is possibly to be found in the fact that the matriculated native, who is normally under European influence or in European employment, is eligible to obtain land in individual tenure. ${ }^{1}$

1 In that case the grant of land free is noteworthy. It is perhaps the case that M. Renkin went further in his speech than he intended. 


\section{CHAPTER XVI}

\section{SOCIAL PROGRESS}

\section{Social Conditions.}

Despite the grave errors of the State régime it must be remembered that the mere existence of an organized government inevitably brought with it no unimportant boons to the Congo people. Of these the most important, the abolition of the slave trade, was unhappily neutralized in some degree by the system which replaced. it, but the abandonment of that policy has enabled the true value of the campaign of 1892-4 to be appreciated. There remains, however, the question of domestic slavery, which, like polygaimy, forms an essential basis of the present economic and social life of the tribe, and which receives legal protection from the native jurisdiction, though the status is not formally recognized by the European courts. Both problems present difficulties of solution which in the Conge have yet to be resolved. Polygamy has often been defended on the ground that it serves to maintain the numbers of the tribes, but the experience of the Protestant missionaries. ${ }^{1}$ at least is decidedly unfavourable to this xiew, and there is not the slightest doubt that polygamy tends to the perpetuation of a deplorably low standard of morality among the natives, and renders it extremely difficult for the poor man, however young, to obtain a wife, while old and rich men can secure as many as they desire. Polygamy is also an effective means of depressing the position of women and encouraging men to evade labour in the fields, which they abandon to their wives. Opinions of the willingness of the Congo

1 See Weeks, Among Congo Cannibals, p .134-9. For its prevalence, cf. Johnston, George Grenfell, i. 361, 365; ii. 671, 676. Masoin (Histoire, ii. 394 ) accuses the Protestants of acquiescing in it. 
native to undertake serious work differ largely, but there is sufficient consensus of opinion that, making all allowances for the distaste for industry engendered by the malpractices of recent years, polygamy is a powerful cause of indolence.

Domestic slavery ${ }^{1}$ serves to produce precisely the same result, for it is to his wives and his slaves that the free man tends to hand over the tasks which normally he should undertake. The advent of Belgian rule has in many ways improved the condition of the domestic slave; above all, it has saved him from immolation on the death of his master, which was so often his fate. Nor are domestic slaves normally badly treated: they frequently prosper sufficiently, and their chief sign of inferiority is the fact that in the councils of the tribe, even if liberated, they count for little or nothing. Nevertheless, as in German East Africa, the toleration of domestic slavery is to be regretted, ${ }^{2}$ and the devising of effective means for terminating the institution within a reasonable period of years is as urgent in the Congo as in East Africa.

The Congolese native is still in a tribal condition, and the State, as has been seen, so far has not made any serious effort to adapt its land policy to the conception of individual tenure. It has been assumed throughout the whole course of Congolese legislation that all ownership is collective, whether the control is vested in the tribal chief or in the tribe as a whole by the custom of the particular tribe. The tribe, however, both by the legislation of 1886 and by that of 1906, hold the land merely for the purpose of occupation and enjoyment; they require the assent of the GovernorGeneral before it can be alienated for any purpose, and the climatic conditions of the Congo have not yet raised the difficulties as to the future disposal of native land which are inevitable in all those parts of Africa, such as Rhodesia,

${ }^{1}$ See Weeks, op. cit. pp. 112-14; J. A. S. xv. 153 ; Cd. 5860, p. 40.

${ }^{2}$ Even Lannoy (L'Orgcnisation coloniale belge, p. 256) treats the institution as an essential part of native society and suggests no change. Contrast British action in Northern Nigeria (Keith, West Africa, pp. 195-8) and Southern Nigeria (ibid. pp. 209, 210). 
where white settlement demands native lands for its satisfaction. The maintenance, however, of the doctrine of collective ownership is obviously a serious hindrance to the adoption by the natives of any form of higher civilization, as has proved to be the case in every part of the world. Moreover, the assumption that collective property is the only form known is clearly incompatible with the recorded evidence of land tenure in other parts of Africa, whether western $^{1}$ or southern ${ }^{2}$, and we have the emphatic testimony of Grenfell, ${ }^{3}$ who had no theories to satisfy, that while the forests were regarded as a common patrimony which every one, chief, freeman, or slave, had a right to exploit as he chose, both personal and real property were private, and inheritance was regulated by strict rules of the ill-styled matriarchal system. In this, as in other cases, the assumption of collective property has doubtless been fostered partly by a priori theory, partly too by failure to recognize any distinction between the political action of the tribe or its head in the distribution of the territory of the State, and the actual holding and using of land. The attitude of the Congo government in maintaining the doctrine of collective ownership was reaffirmed in 1912, when it offered to hand over domain land for natives for the purpose of cultivation, but only if groups of natives applied, and it may be hoped that in due course the plan will be adopted of encouraging indiviảual tenure, subject to such conditions, of course, as will prevent unwise alienation. The problem is difficult, but not insoluble, though it means the creation of new difficulties and complications for the State, the inevitable accompaniment of the evolution of higher civilization.

In no respect has the government of the State and the colony alike been more faithful to the Berlin and Brussels Acts than in the discouragement of the liquor traffic in the territory. Measures had been taken by the State to this end, even before the principles of action were formally announced by the Brussels Act of 1890, and a series of

1 Keith, J. A. S. 'xi. 325-31.

2 Ibid. vi. 202-8.

3 Johnston, ii. 697. 
decrees extended prohibition to the whole area, first up to the River Inkisi, then to the Kwilu, then to the M'Pozo, that is up to Matadi. Finally an Ordinance-Law of the GovernorGeneral of November 23, 1912, ${ }^{1}$ which was confirmed with a slight postponement of date by the King, ${ }^{2}$ extended to the whole of the colony the rule that the sale and delivery to natives, or the possession by them of distilled alcoholic liquors, should be forbidden under heavy penalties, which were made applicable to heads of commercial houses whose workers violated the law. The introduction of absinthe, even for European consumption, was prohibited by a decree of October 15, 1898, and the amount of liquor which can be supplied to a European is reduced by an Ordinance of December 11, 1899, to three litres a month. The law of 1912 does not merely strike a blow at the effect of imported liquor, but is aimed at preventing the distillation of sugarcane, bananas, and even manioc, which had been practised in the interior, while rum and gin drinking had been prevalent on the coast. When it is realized that the law of 1913 meant the sácrifice by the Government of 500,000 francs revenue, the admirable character of its action is the more apparent, and in this regard the Government of the Congo may fairly claim to stand above the average of European governments in Central Africa.

The State has also persevered in efforts to limit the possession by natives of fire-arms and ammunition, a policy desirable not only in the interest of the Government but also as a mode of repressing tribal quarrels and the revival of slave-trading. As the provisions of the Brussels Act of 1890 in this regard proved inadequate, an agreement was made just before the transfer of the State, by the Congo, the United Kingdom, France; Germany, Portugal, and Spain, on July 22, $1908,{ }^{3}$ under which provision was made

${ }^{1}$ Cd. 6606, pp.93-5.

${ }^{2}$ Cd. 6606, p. 114. The rigour of the enactment was, however, modified by a decree of August 6,1913, replacing the Ordinance and reducing the penalties, and replacing the boundary of prohibition at the M'Pozo.

${ }^{3} \mathrm{Cd} .4320$. 
for the entire cessation, with effect from February 15, 1909, of the importation or delivery to the native of fire-arms, ammunition, and gunpowder, in a large area of the Congo and the adjoining territories as defined in the Protocol. The Protocol was to remain in force for four years, and provision was made for its continuance in operation unless any of the Powers notified intention of withdrawal. Moreover, by a declaration of June 15, 1910, ${ }^{1}$ which took effect from February 1, 1912, permission was given to any Power to increase beyond the limit of 10 per cent. allowed by the Brussels Act of 1890 the import duties on arms and ammunition. The strict application of the treaty of 1908 was, however, found inconvenient, as powder was necessary, for the legitimate purpose of hunting, to the natives, ${ }^{2}$ and an Ordinance-Law of the Governor-General of November 23, 1912, supplemented by an enactment of October $1,1913,{ }^{3}$ permitted after February 15, 1913, the trade in flint-locks and trade powder in the whole of the Congo.

\section{Religion.}

In addition to, and more important than, the efforts of the State in effecting the spread of civilization among the natives must be reckoned the work of the missionaries, both Protestant and Roman Catholic, in the Congo. The beginnings of Protestant missionary effort ${ }^{4}$ on the river are to be traced to the initiative of Mr. Arthington, who in 1877 offered the Baptist Missionary Society the sum of $£ 1,000$ towards the project of establishing a mission station at San Salvador, which had long since ceased to preserve any but the faintest reminiscence of its past Christianity. This establishment was designed by Mr. Arthington to be a preliminary to efforts to establish connexion with Nyangwe, for

${ }^{1}$ Cd. 6037.

${ }^{2}$ For the earlier legislation see Cd. 6606, pp. 26-34; for the amount of powder sold in the Kasai in 1912, see Cd.6802, p. 17.

${ }_{3}$ The trade in arms of precision was also regulated by another Ordinance of the same date.

4 See Johnston, George Grenfell, and Masoin, Histoire, ii. 373-95. 
Mr. Arthington had the good sense to realize that Cameron's journey had solved the secret of the Congo. The Society. then issued a public appeal which met with a generous response, and enabled the dispatch to the new field of labour of Messrs. Grenfell and Comber, who had already done excellent work in the Cameroons. They reached San Salvador on August 8, 1878, and received a warm welcome from the King, Dom Pedro. A first effort to attain Stanley Pool failed, and Comber returned to England to obtain additional aid. This was readily accorded, and in 1879 Comber, accompanied by Crudgington, Hartland, and Bentley, arrived at San Salvador. On March 10, 1881, Bentley and Crudgington actually attained the site on which Leopoldville was afterwards built, but the influence of Malamine availed to secure them so unfriendly a reception from the natives that they were fortunate to escape alive. The advent of Stanley, however, was the signal for the return of the missionaries to the Upper River, and by 1908 they. had founded nine stations, and claimed 2,450 communicants : to attain this result more than ten million francs had been expended, and of 160 missionaries fifty had given their lives. A special distinction was accorded to the mission by the linguistic studies of Bentley and the explorations of Grenfell, whose services in this and other regards caused him to be chosen by the King to delimit on behalf of the State part of the Congo-Angola boundary in 1892-3. Grenfell was slow to express disapproval of the methods of the State, but in the years from 1903-6 he repeatedly represented to the local authorities the errors of the administration, and was in consequence the subject of strong remonstrances from the Governor-General.

Slightly earlier in time on the Congo was the Livingstone Inland Mission, represented by Strom and Craven and supported by Dr. Guinness, who also took an active part in the campaign against the errors of the State régime. In 1884 it was handed over to the American Baptist Missionary Union, which by 1909 had thirty-two establishments with 5,000 adults and 7,000 children among its adherents. Some, 
however, of the Swedish missionaries declined to accept the transfer and joined a Swedish mission founded in 1881. In 1885 the Christian Missionary Alliance of New York began operations; in 1887 the Congo Balolo Mission was founded by a former member of the Livingstone Inland Mission; in 1890 the American Presbyterian Mission appeared on the scene; and in 1896 the Christian Disciples Mission took over a station at Bolengi from the Baptist Union. The Plymouth Brethren were also early in the field, and the Westcott Independent Mission has workers in the Congo. By 1908 no less than 211 missionaries were at work, and the services of the missionaries in providing not merely religious instruction, but schools, and dispensaries, and hospitals, have been admirable. The missionaries, unlike their Catholic confrères, have not attempted, with hardly an exception, the work of educating native orphans to be artisans and agriculturists, and for this reason and because they use English in their dealings with their pupils they, naturally enough, have not received the same support from the State as the Roman Catholic missionaries. ${ }^{1}$ To their courage and independence, however, the Congo owes a heavy debt, for without them ${ }^{2}$ there would have been little chance of awakening the conscience of Europe to the state of affairs in the Congo, and the comparative unpopularity in the territory which their courage cost them is as honourable to them as it is discreditable to their opponents.

Not less important has been the work of the Roman Catholics in the state. ${ }^{3}$ In 1860 rumours of the persistence of the Christian faith at San Salvador reached Livingstone, and in 1865 three emissaries of the Congrégation du SaintEsprit sought to discover and revive these remains of the former influence of Portugal, but their researches showed

1 Lannoy, L'Organisation coloniale belge, p. 247. For an indictment of the Protestant missions see Masoin, Histoive, ii. 393-5.

2 Including Sjöblom, Clark, Weeks, Scrivenen Harris, Morrison, and many others. For Grenfell's view see Johnston, i. 375-81.

3 Masoin, Histoire, ii. 303-53, an enthusiastic if uncritical panegyric. 
that the rumours which had come to Livingstone were without foundation. In 1873 three further emissaries established a mission at Landana to the north of the Congo, and four years later they crossed the river to establish themselves in San Antonio. They advanced to Banana in 1880 and to Boma in 1881, and in 1885 they proceeded up the river and established a post at Kvamouth, but this station was surrendered in 1888, the mission thenceforth confining its operations to the coast region. Plans on a grander scale were devised by Cardinal Lavigerie, who determined to follow up the work of the International African Association by an energetic campaign. Leo XIII proved sympathetic, and on February 24, 18i8, created four Apostolic Vicarages for Central Africa, and Lavigerie hastened to dispatch in 1879 to Tanganyika members of the community of the Pères blancs 'd'Alger, who were to lead the movement. Further missionaries followed the pioneers, and the western coast route was also used. The advent, however, of these French priests, and suspicions apparently of the political aims of the energetic Cardinal, seem to have moved Leopold II to action in order to secure Belgian co-operation. $\mathrm{He}$ founded in July, 1886, a seminary at Louvain, and obtained in the following year promise of aid from the Congrégation du Cœur immaculé de Marie at Scheut, and after negotiations with Lavigerie obtained a decision of the Pope of May 11, 1888, which left the Apostolic Vicarage at Tanganyika to the Pères blancs d'Alger on condition that only Belgians should be sent there, and created the Apostolic Vicarage of the Congo entrusted to the Pères de Scheut and to the Seminary of Louvain. The development of the work has since been continuous, the Jesuits lending valuable aid, and has necessitated an elaboration of organization. An Apostolic Prefecture was created for Uele in 1898 (May 12), for the Upper Kasai in 1901 (July 26), and for the Kwango in 1903 (January 26). An Apostolic Vicarage at Stanley Falls came into existence in 1908 (March 12), and there are missions of the Pères du Saint-Esprit at Kindu, of Trappists in the Equator, and of Redemp- 
torists at the Cataracts, where they replaced the secular clergy of Ghent, who from 1891-9 carried on a most valuable work in the interest of the thousands of natives who were then engaged in the work of transport and of railway construction.

By a decree of December 28, 1838, which arose out of his negotiations with the Pope, Leopold II accorded to religious bodies the right of obtaining a civil status, with power to hold land in such amount as the Governor-General might deem necessary for the purposes of their work, such amount in no case to exceed more than fifty hectares in one locality. A decree of July 12, 1890, introduced the important principle that the State should charge itself with the education and maintenance of children rescued from the slave-tradersthen a numerous class-or abandoned, or orphans, or who were in fact not properly brought up by their parents. The means of carrying out this policy seemed to be afforded by the missions, and a decree of March 4, 1892, gave to religious bodies, if approved by the State, the right to exercise over them the tutelage of the State. As the children were only entitled to be set at liberty at the age of twenty-five, the burden of rearing them was a serious one, and the Protestant Missions decided that it would be unwise to undertake it, especially as the extraordinarily mixed character of the pupils rendered the difficulty of language almost insuperable. ${ }^{1}$ The Catholic missions, however, decided to use this convenient method of proselytism and founded the system of fermes-chapelles, ${ }^{2}$ which was destined to bring upon them severe criticism. The most striking of these was the report of the Belgian Commission of Investigation of 1904-5, which was unsparing in its condemnation of the actions of the missions. It found ${ }^{3}$

${ }^{1}$ Pickersgill, C. $8649-30$, p. 11 ; cf. Cd. 6606 , p. 80 ; Bulletin officiel, 1911, pp. 79-84.

2 Defended, very ineffectively, by R. Pierpoint, Bulletin de la Société belge d'Études coloniales, No. 5, May, 1912. See Johnston, George Grenfell, i. 471-3.

3 Masoin, Histoire, ii. 362, who attempts a defence of their actions. 
that they exercised constraint on their charges by chains and flogging; that they forbade their acquisition of property; that they separated husbands and wives, and only with difficulty would accord permission to marry. Moreover, they pointed out that many of the children alleged to be abandoned were really taken away from, or forcibly withheld from, their parents or natural guardians, children in the Congo being regarded as valuable objects and hardly ever voluntarily abandoned. It is idle to discount the findings of this body, which was selected by the King himself, and was composed of two Belgians and a Swiss, as biased by the evidence of officials of the State, whose ungodly lives were shamed by the virtue of the priests, or by the reprasentations of Protestant missionaries. The evils were the outcome of a radically wrong system which entrusted to a body of men undue power; and it is significant that practically the same allegations were made in 1912 by M. Vandervelde, who had himself travelled in the Congo, and that the Government reply was far from vindicating the missions. ${ }^{1}$ Leopold II, however, was too conscious of the value of the aid he derived from the Church in its campaign for him against the attacks of his opponents to permit himself to be moved by the representations even of his own Commission: on the contrary, to emphasize his disregard for the condemnation of the Commission, he arranged a convention in May 26, 1906, with the Holy See, under which missions established by common accord between the civil power and the Church should receive gratuitously in full ownership 100, or in special cases 200, hectares of arable land, on condition of undertaking the instruction of children, and priests employed as colonial chaplains should be paid by the colony. It was hardly wonderful, then, if Protestant missionaries commented with asperity on the readiness shown by their Catholic confrères to shut their eyes to the atrocities committed by their countrymen, and contrasted the favour shown to the Catholic priests by

${ }^{1}$ Above, p. 156. The age of release was reduced to 21 years by one of the reform decrees of June $3,1906$. 
the State with the determined efforts made by the Government to prevent the extension of their activities by refusing them power to acquire land. ${ }^{1}$ In this and other matters, however, the new régime brought relief: the system of tutelage was relieved of one of its most dangerous features by the alteration of the age at which the pupils were set free to eighteen from twenty-five, under a decree of January 3 , 1911, while the new Government gave the most positive assurances in $1912^{2}$ that there would be no further refusal of sites for Protestant mission stations, an undertaking of which special mention was made in the British note of June 27, 1913, conveying intimation of recognition of the transfer of the Congo to Belgium. ${ }^{3}$

Missionary establishments enjoy certain valuable privileges of exemption from, or reduction in, rates of taxation, and a decree of June 3, 1906, permits the grant to Catholic missionaries who apply for it of the right to keep records of civil status and to perform civilly the marriage of natives whom they have previously married by a religious rite.

The number of converts claimed by the Catholic missions, partly, doubtless, as the result of the system of fermeschapelles, was double that of the Protestant missions in $1907,{ }^{4}$ and the proportions do not seem to have altered in later years. In both cases there must be doubt as to the genuineness of many of the conversions, and in any event the process of Christianizing the people must inevitably be slow, for the doctrines of that faith contradict polygamy, and, as in West Africa generally, and in some measure also in South Africa, to insist on the renunciation of polygamy is as yet a fatal bar to acceptance of the faith, while to

1 At the third General Conference of Evangelical Missionaries, held at Kinshasa on January 9, 1906, attended by missionaries from the United Kingdom, the United States, Canada, Germany, Sweden, Norway, and Denmark, fifty-two missionaries signed a protest against atrocities and against the refusal to assign sites for mission stations.

${ }^{2}$ Cd. 6606, p. 39 (July 3, 1912).

3 State Papers, cvii. 352, 353.

4 They claimed 41,000 native Christians and 343 missionaries in 1907; Masoin, Histoire, ii. 325 (cf. however, pp. 410, 411). 
compromise with the system is to degrade Christianity and to sap its value as a civilizing influence. But it would be unjust not to give a due meed of praise to the devoted labours of both Catholic and Protestant missionaries alike for their labour in an unfruitful soil, under conditions often of great personal hardship, and for no reward other than the consciousness of duty accomplished, and the possibility of higher things brought to a pagan race, nor to mention that in their work the Protestant missionaries have derived great aid from their wives and from women missionaries, while the efforts of the Catholics have been much furthered by the devotion of many nuns.

Despite, however, missionary endeavours the vast majority of the Congo natives are pagans, nor is there any probability of their conversion at an early date to a higher faith. The paganism of the Congo is unprogressive, ${ }^{1}$ and bears only the remotest likeness to the higher religious faiths of the world. There is, it is true, evidence of the existence before any real possibility of Mohammedan or Christian influence of a vague belief in a supreme deity, but he was deemed to have ceased to interest himself in the affairs of the world and was therefore not the object either of worship or prayer. The practical faith of the native is animistic; he believes that he is surrounded by countless spirits, invisible to him, but discernible by the medicine man, who has power to attract them to the fetishes which he makes and to control them, either using them to injure the enemies of his patron, or averting from him the evil which they else would bring. On death the spirit set free is dangerous and must be appeased: hence the human sacrifices which Belgian rule has largely eliminated. Belief in witchcraft is widespread, and proves, as always, a strong barrier to the growth of civilization.

The rival of Christianity among the natives is Mohammedanism from the east rather than from the north, whence its advance was stemmed by the Belgian campaigns of

${ }^{1}$ Cf. Johnston, George Grenfell, ii. 632-71; Weeks, Among Congo Cannibals, pp. 246-93. 
1890-98, though with the advent of peace a slow process of infiltration may be expected. From the east, however, the influence of the Crescent has long been flowing: Ujiji was reached as early as 1840; in 1865-6 the Arabs discovered the Upper Lualaba and the Lomami; in 1871 they were at Nyangwe, and they followed Stanley down to the Falls. Until 1892-4 they dominated the whole of the east of the State, and though they do not seem to have adopted any forcible proselytism, it was quite inevitable that the natives of Manyema, the Bakusus, who found themselves unable to defeat them by force of arms, should have adopted the faith of their conquerors. From the admixture of Arabs, few in number, with the negro women, arose the Arabisés, a race much superior in culture, and even in physique, to the negro, while their civilization was manifested in the vast expansion of cultivation-largely ruined in the Arab wars-the broad streets and rectangular houses ${ }^{1}$ of their towns, the introduction of a legal system based on Mohammedan law, and their busy trade relations with Zanzibar. Through them Mohammedanism spread from Manyema over the Aruwimi country, between the rivers Lindi and Lomamai. Even after their political downfall, Lord Mountmorres, travelling in 1905 in the Aruwimi country, was struck by the resemblance between the large thriving towns there and those in Morocco. ${ }^{2}$ In the country between the Falls and the British and German frontiers he found the chiefs and notables intelligent and well conducted, able to read and write in the Arabic character, and well versed in the Koran, of which and of other devotional works copies existed in every village. In all the larger villages Mohammedan schools existed, at which attendance was enjoined on all the children by the chiefs. The men, who wore the traditional Mohammedan dress, were devout and rigorous in the observance of their faith, while the women, decorously and becomingly attired, were treated with a degree of respect and consideration which was not paralleled in the

${ }^{1}$ Cf. Johnston, George Grenfell, ii. 743.

2 Cited by Johnston, i. 321, n. 1. 
pagan tribes. On the other hand, Mr. Consul Mackie, ${ }^{1}$ who travelled in the same area in 1911, in describing the nativesof the territories lying below Stanley Falls, wrote:

'The Tambatamba (Arabisés)-Bokusu, Batetela, and other followers of Arab families-are congregated at Stanley Falls on both banks as far down as La Romée. These two latter tribes live in large mud-wall houses, detached, with yards or courts. They are both farmers and stock-breeders. The former are clean, clothed, and polite, while the latter are, like the Arabs, superior in appearance, dress, and mannersin fact, the aristocracy of the land. Their fields are tilled by women and dependents, or slaves. They are not true Arabs, though there are a few of these too among them. In all things except religion the Tambatambas follow their Arab conquerors of earlier days, but of religion they have only the superstitions without the bonds, rules, or system of worship of the Mahomedans.'

Between these two versions there is probably no fundamental discrepancy: Lord Mountmorres's account refers rather to the attitude of the chiefs, who maintain the Arab tradition, while Mr. Mackie deals rather with the actual attitude of the body of the people themselves, who remain papan at heart beneath the veneer of Mahommedanism, and who are, moreover, at no small distance from Manyema, the true head-quarters of the Arabs.

The possibility of the advance of the faith of Islam over the territory is one which has naturally invited the consideration of Belgian administrators, especially as German East Africa is deeply permeated by the influence of that faith. The attitude of the State must, in accordance with the Berlin Act, be one of complete toleration, and the Colonial Charter ${ }^{2}$ reiterates this principle in very wide terms. But while opposition would be as impolitic as it is illegal, it would nevertheless be unwise to take any active steps to promote a faith which is certainly inimical to the development of Christianity. ${ }^{3}$ Mohammedanism has in itself the advantage over Christianity that it is consistent

${ }^{2}$ Cd. 5860, pp. 62, 63.

2 Art. 2.

${ }^{3}$ Cf. Masoin, Histoire, ii. 119-24. 
with polygamy; with domestic slavery, and with the social and economic depression of women; but, on the other hand, it is in many respects too high a faith to attract the pagan, and the former cause of its success, the political power of the Arabs, has disappeared for ever. The chief danger to the State which might arise would be if there were any effort at forcible repression of the faith in neighbouring territory, such as was apparently contemplated in German East Africa before the war, for Islam is a faith which flourishes on persecution, and the contagion of revolt might easily spread to the Congo.

\section{Education.}

The scanty number of the European population of the Congo has rendered it unnecessary to make provision for the education of white children, though such provision will be requisite in due course. In Belgium itself, besides the Colonial School for selected candidates for the service of the Congo, instruction can be had in the Higher Commercial Schools, whether independent or attached to the Universities. At Vilvorde instruction is provided in colonial agriculture and horticulture, while the Garden at Laeken affords means for investigation by members of the agricultural and forest departments of the State. But the important question of the study of native languages has been left entirely in the hands of missionaries. In the Congo, by a ministerial order of July 28, 1910, a system of libraries has been established available for consultation by Europeans in search of information on the Congo.

For the education of the natives much has been done by the State and by private endeavour, with or without State aid. The first schools created by the State were those for children freed from slavery or abandoned or without parents, created by the decree of July 12, 1890, above referred to, under which the children in return for their education were to perform such tasks as were directed by the GovernorGeneral. The rules issued by this official on April 23, 1892 
provided that the children should be trained with a view to filling the lower offices in the armed force. The actual education and care of the children is entrusted to the Pères de Scheut and the Frères de la doctrine chrétienne, and the schools maintained are situated at Nouvelle Anvers and Boma. The age of liberation of the children, originally fixed at twenty-five years, was lowered first to twenty-one years in 1906, and by a decree of January 3, 1911, to eighteen years, thus obviating many criticisms. Pupils from these schools may be drafted into the military school for subofficers intended to provide candidates for inferior accounting duties in the armed force, which was established by an Ordinance of March 30, 1897, while from the school at Boma are selected youths to be trained as clerks for the public service. ${ }^{1}$ The course of instruction lasts for two years, and those who pass with credit the final examination are allocated to suitable posts by the Governor-General.

In addition to these schools, which are only open to wards of the State, there are professional schools attached to the Government workshops at Boma, Leopold ville, Stanleyville, Lusambo, \&c., which are open to boys between the ages of twelve and twenty whose parents assent to their entering them, and who are recommended by the chief to the Commissioner of the district; despite these efforts, however, there is still a serious shortage of workers such as carpenters and masons. Since the annexation a large number of primary schools has been provided by the Government, in which instruction is accorded by teachers of the Congrégation, and in 1913 the first school for the sons of chiefs was opened at Stanleyville. In all the primary schools manual work of various kinds forms an essential part of the course of instruction as well as the teaching of the French language.

Non-governmental schools have been provided in large numbers by both Protestant and Catholic missionaries ${ }^{2}$ : of

1 Ordinance of February 28, 1906 .

${ }^{2}$ In 1912482 Catholic priests and sisters and 190 Protestant mis- 
these many are entirely free from State control, in accordance with the Charter, but others are subjected to State supervision in return for State aid. These fall into two categories: the first of these comprises the schools for abandoned and orphan children on the same model as the State schools. To maintain such establishments authorization from the Governor-General is necessary; the programme of instruction must be submitted to him; and the schools are subject to his inspection. The head of the school is invested by the Civil Code ${ }^{1}$ with the powers of Tutor, and the law expressily provides the penalties which may be used for disciplinary purposes. ${ }^{2}$ The age for the liberation of pupils in these cases also is now fixed at eighteen years. The second category is composed of schools opened in accordance with the Concordat with the Holy See of May 26, 1906. In return for free grants of land the mission undertake to provide schools, whose programme must be approved by the Governor-General. The subjects included must comprise teaching of the languages of Belgium and of manual work, and reports must be sent to the GovernorGeneral, whose duty it is to see that the schools are maintained in a sanitary condition.

The scientific study of conditions in the Congo is represented primarily by the Museum of Tervueren reorganized by a royal arrêté of January 1, 1910, sections of economic science and of moral and political science being added to the existing section of agriculture. In the Congo itself the medical luboratory at Leopoldville and the botanic garden at Eala have accomplished valuable work of research. The mapping of the colony and the taking of meteorological investigations are recent undertakings of value. Much, however, remains to be done, for the information as yet accumulated regarding the people of the Congo is small in

sionaries were engaged in this task with results freely criticized by Mr. Lamont, Cd. 6606, p. 80.

1 Art. 243.

2 Decree of March 4, 1892 ; Ordinance of August 3, 1892, and August 23, 1900 . 
comparison with the vastness of the area, while the primitivo character of the tribes renders them subjects of special interest, and emphasizes the need of precise observation before the advance of civilization confuses their ideas and diminishes their ethnological interest.

One problem of importance has of late, with the growth of European population, pressed itself on the attention of the Government, the position of half-caste children, a class whose condition is no less complicated in the Congo than in every other African territory. The provision of a school in which these unfortunates can be educated is the only effective step which the State has been able to take, but the efforts which are made by the provision of special allowances ${ }^{1}$ to induce the officials to take their wives with them to the Congo should be noted with satisfaction as the best means of checking the development of this difficulty.

\section{Public Health.}

The annexation of the colony has been followed by a considerable extension of the medical service of the colony, which was completely reorganized by a royal arrêté of June 20, 1910. Under that measure the service consists of a Chief Medical Officer, Medical Inspectors, Principal Medical Officers, Medical Officers of the first and second classes, and apothecaries, with pay from 10,000 to 20,000 francs, serving on similar conditions to the civil service generally. Their training is given in the School of Tropical Medicine created at Brussels by a royal arrêté of September 10, 1910, three courses of six weeks' duration being delivered annually. Promotion to the highest rank depends on proof of knowledge and research. It has unhappily proved difficult to maintain a full cadre: in 1912 the establishment of seventy-eight ${ }^{2}$ was four short of its complement. In any event the State provision would be wholly Inadequate but for the invaluable services of missionary doctors, while other officials have acquired sufficient ele-

${ }^{1}$ Lannoy, L'Organisation coloniale belge, p. 95.

${ }^{2}$ Now 100. 
mentary knowledge of medicine to be of assistance. Training of a simple kind can be obtained at an elementary course of the Tropical School in Brussels, while a practical course in sanitation is given at Boma, intended chiefly for the instruction of those in charge of isolation stations and the heads of posts of sanitary observation.

Under an Ordinance of April 24, 1899, Boards of Health exist in the capitals of each district and territory, and also by an Ordinance of March 27, 1911, at Banana, Matadi, and 'Thysville. These boards are composed of three members sitting ex officio or on the nomination of the head of the district or territory ${ }^{1}$ : they are officers of judicial police, and must report infractions of sanitary rules as well as advise on all measures for sanitation in the area.

For the treatment of disease the colony has many hospitals, both for Europeans and natives, some provided by the Government, some by missionary enterprise. Isolation hospitals for contagious disease have also been provided by the Government; the personnel of these establishments is largely provided by the missionaries, but a school for the training of native hospital assistants exists at Boma. Preventive measures against the spread of disease have been enacted, and there are rules regulating the mode of burial, the provision of sanitary accommodation by heads of large establishments, the maintenance of roads and the cleansing of villages, the standard of food exposed for sale, and similar matters. Care has also been taken to prevent the advent of rabies from Rhodesia.

By far the most serious evil harassing the colony is the scourge of sleeping sickness. ${ }^{2}$ The scientific study of the disease is conducted at the Laboratory at Leopoldville, which was created by the Colonial Society of Brussels in 1898, and taken over in 1910 by the colony. The success met in combating the disease has been in some districts satisfactory, but it remains a menace which drains the spare resources of

1 Decree of July 1,1912 , making the necessary changes consequent on the alteration in the system of subdivisions of districts.

${ }^{2}$ For its spread in the Congo see Johnston, George Grenfell, ii. 547-53. 
the State. The King has wisely devoted to measures against it a large proportion of the instalments of the fifty million francs placed at his disposal by the Additional Act of Cession. Until the danger of its spread has disappeared, the campaign against other diseases is naturally difficult to carry out, but much has been done to combat small-pox among the natives. ${ }^{1}$ The health of the Europeans has been greatly improved by the systematic cutting down of bush round the townships, the drainage of pools, the destruction of the larvae of the anopheles by petrol, the building of fine houses for the staff on a scale unknown in British territories, and, above all, by the substitution of fresh food for tinned, and, though the Congo is still unhealthy for Europeans, the acute period of danger has passed. ${ }^{2}$

\section{The Protection of the Natives.}

The Charter provides by Article VI for the existence of a Commission charged with the duty throughout the whole extent of the territory of the Congo to watch over the protection of the natives, and the amelioration of their moral and material conditions. This body, which replaced the abortive and useless Commission of 1896, is presided over by the Procurator-General of the Court of Appeal of the capital, and is composed of members chosen by the King for their special qualifications by reason of function or occupation to fulfil the protecting mission of the Commission. The number, originally fixed at seven by the Charter, was left in the discretion of the King by the amending law of March 5, 1912. The Commission is now composed of its president and ten members ${ }^{3}$; they must be summoned once a year, and receive pay of 100 francs a day of the session, while their travelling expenses to and from the place of

1 Vaccination is popular and effective. Other diseases of importance are dysentery, pneumonia, and syphilis, the latter a recent product through European influence; Johnston, ii. 553 sq.

${ }^{2}$ Cf. Masoin, Histoire, i. 74.

3 Royal arrêté of June 1, 1912. 
meeting, which is determined by the president, are defrayed by the Government. An annual report on the measures desirable in the interests of the natives must be presented to the King and published. In addition to this provision the Charter ${ }^{1}$ imposes on the Governor-General the obligation of securing the preservation of the natives and the amelioration of their conditions, and expressly bids him favour the expansion of individual liberty, the progressive extinction of polygamy, and the development of property.

The powers thus conferred are not, however, to be treated as more than general prineiples, which so far the State has not done much to carry into effect. ${ }^{2}$ As has been seen, neither domestic slavery nor private property in land has yet formed the subject of governmental activity, and the policy of the State in these matters is still one of inaction. On the other hand, polygamy has exercised the minds of the Commission and has resulted in efforts of the Government, not to make it illegal or to abolish it, but to restrict its scope and prepare the way for its extinction. ${ }^{3}$ On the advice 'of the Commission in 1913 the Government resolved to extend the prineiple of the abolition of polygamy among soldiers and State labourers by refusing to recognize the acquisition of wives by purchase, exchange, as tribute, or by capture in-war, as distinct from marriages contracted by consent of both parties, with or without the customary bride price to the woman's family, by disallowing the acquisition of wives by inheritance, and by proscribing the taking possession of children below the age of puberty for subsequent marriage. The Commission also recommended that the head tax for each wife after the first should be increased to half the main tax, and that the restriction of the tax to

1 Art. 5.

2 Lannoy (L'Organisation coloniale belge, pp. 256, 257) regards them, it is clear, as rather futile indications of an impracticable idealism.

3 See Cd. 6802, pp. 39-41. It is not quite clear that the law treats polygamous marriages as conferring the status of wife under its legislation affecting wives (e.g. the decree of August 17, 1910, requiring a husband's permission for the engagement of a wife). 
sixty francs in all should be abolished, and they aiso suggested the establishment in tribal limits of villages for natives who had served the State in which monogamy should be enforced, and definite standards of morality and sanitation insisted upon.

The range of the action of the Commission is unlimited, and they have in their reports devoted much attention to every kind of question touching the moral and material interests of the people. They have pressed for the observance of the natives' wishes in the selection of chiefs, the erection of good houses for natives in the employment of the State and private individuals, the grant of encouragement to natives to provide themselves with permanent and suitable houses - a first step to the recognition of private property in land,-the prevention of abortion, the encouragement of the birth-rate by the provision of maternity homes, the treatment of sleeping sickness by atoxyl and of syphilis by salvarsan, the discouragement of vagrancy and the provision of workhouses, and many other reforms. It was on their advice that the Government resumed permitting the use of flint guns by the natives, prohibited the sale to natives of distilled liquor, provided schools for the sons of chiefs, and made provision to permit every soldier sent to an instruction camp to be accompanied by his wife, a concession of great moral value in a system of compulsory service. The Government were also influenced in their decision to entrust certain powers of dealing with petty offences by natives to territorial administrators by the resoIution of the Commission in 1913 on the growing disregard for authority on the part of the natives, ${ }^{1}$ a clear proof that the Commission, if humanitarian, is not in the slightest degree devoid of practical sense. The Commission has also distinguished itself by reminding the Government of the paramount importance of securing the removal of the last remains of the old system in the shape of the agreements

${ }^{1}$ Of this there is much independent authority, British as well as Belgian. 
with those companies which still have concessions in which the State is interested.

'The Charter confers on the individual members of the Commission, as well as on that body, the special right, and therefore duty, ${ }^{1}$ of denouncing crimes against the natives to the officers of the Public Prosecutor, whose duty it then is to set the law in force against the offenders. In addition, the officers of the Public Prosecutor are invested by a decree of August 17, 1910, with the duty of watching over the interests of the natives, including immigrants, especially contract labourers, and securing the due observance of contracts of service entered into by them. They have also the right to bring actions on their behalf against Europeans, and possibly also against other natives. ${ }^{2}$ Moreover, by a derogation to the general rule, in a criminal case where the person injured is a native the courts are expressly bound to allocate to him any compensation or damages which are due to him by local custom. ${ }^{3}$

1 This is doubtless the point of the provision of the Charter which Lannoy (L'Organisation coloniale belge, p. 255) somewhat hastily characterizes as useless, every citizen having the right to denounce crimes.

${ }^{2}$ Art. 44. The right to take action against a native has been affirmed by a decision of the Court of Appeal at Boma of March 11,1911; Lannoy, op. cit. p. 258, n. 1 .

${ }^{3}$ Decree of August 11,1913, Art. 86, a provision already included in a decree of August 31, 1906. 


\section{CHAPTER XVII}

\section{ECONOMIC DEVELOPMENT}

\section{Communications.}

ThE Congo is the fortunate possessor of an admirable means of communication in the Congo and its affluents, which present a total of some 12,000 kilomètres of navigable stream, though in parts considerable expenditure is, and has been, necessary to overcome defects in the navigation. ${ }^{1}$ There remain, however, certain long stretches of the river on which navigation is impossible, notably the Cataract region, in which the river in the course of 250 miles falls 560 feet; seven rapids and much broken water between Stanleyville and Ponthierville, and the Hinde Falls between Kindu and Kongolo ; while on the Upper Lualaba there are the Kallengue, Kabulula and N'Zilo Falls, on the Upper Luapula the Mambirimi Rapids, and between Moero and Kiambi the Lulua falls, in a distance of 180 miles, 1,220 feet. The task of providing an alternative to a route by road to Stanley Pool was emphasized by Stanley, and, commenced in 1890, terminated successfully in 1898. The distance is 398 kilomètres, the gauge 76 centimètres, and the Company received not only $15,000,0 \mathrm{C0}$ francs of its capital of $82,000,000$ francs from the State but also a subsidy of 1,500 hectares a kilomètre.

The completion of this line was followed by projects of connecting Stanleyville by rail with Mahagi, ${ }^{2}$ which would

${ }^{1}$ See Les Communications par chemin de fer et par voie fuviale au Congo Belge (in Bullctin.de la Société belge d'Études coloniales, No. 4, April, 1912), and the official Exposé de la question des chemins de fer (Brussels, 1911). The navigation of the river is sulject to the rules of the Berlin Act, which have been put in execution by the Government.

2 Masoin, Histoire, i. 64, 65. 
have facilitated the advance to the Nile, on which the King bad set his heart, but the difficulties of construction proved to be too great to permit of action, and instead attention was directed to the task of establishing connexion with the Katanga by providing railway links for the unnavigable parts of the river. For this purpose an agreement was made with the Great Lakes Railway Company in 1902, by which the State undertook to guarantee repayment of the Company's capital with 4 per cent. interest in ninety-nine years, and to assign to it 4,000,000 hectares for each twentyfive million francs of capital, the soil to be worked by the State on joint account, and the minerals to be exploited by the Company on similar terms. The actual capital raised was seventy-five millions, but in lieu of twelve million hectares the Company accepted three-quarters of the profits from eight million hectares, an obligation modified in 1913. The lines constructed by the State were to be worked by the Company, which also was to provide a flotilla to navigate the stretches of the river between Ponthierville and Kindu, and Kongolo and Bukama: the lines constructed are those from Stanleyville to Ponthierville, 127 kilom., completed on September 1, 1906, from Kindu to Kongolo, 355 kilom, and from Kabalo ${ }^{1}$ to Tanganyika, 275 kilom., all constructed on the metre gauge, and the State, by virtue of its relations with the Company, has a voice in the administration.

By a decree of March 11, 1903, authorization was given to the Compagnie du chemin de fer du Katanga to construct a line connecting the south of the Katanga with a point on the Lualaba below its confluence with the Lufira. The initial capital was provided to the extent of $1,000,000$ francs, three-fifths by the State and two-fifths by Mr. R. Williams and his colleagues. There was, however, delay in completing the necessary arrangement for a connexion with

${ }^{1}$ A day's journey up-stream from Kongolo, it having unhappily proved impossible to bridge the Lualaba, and thus to avoid transhipment at Kongolo. The line was opened to traffic in March, 1915. A decree of June 18,1903 , regulates the situation. 
the Rhodesian lines, and it was only after Mr. Williams had succeeded in establishing in 1908 the Rhodesia and Katanga Junction Railway and Minerals Company that on January 25, 1909, the capital was increased by 25 million francs; this sum was provided to the extent of 10 millions by the Union minière du Haut Katanga, substituted for Mr. Williams, and for the rest by the Compagnie du chemin de fer du Bas-Congo au Katanga, substituted for the State, the sum in question being deducted from the produce of a loan of 150 millions for railway construction sanctioned by a decree of June 3, 1906. The sum was intended to cover the cost of construction of the line from the border at Sakania to Elizabethville, and the work was carried out by the firm of Pauling, acting for the Compagnie du chemin de fer du Bas-Congo au Katanga. A further addition of $\mathbf{5 4}$ millions of capital was made to cover the completion of the line from Elizabethville to Bukama ${ }^{1}$ : the funds were supplied by the Compagnie du chemin de fer du Bas-Congo au Katanga, which constructed the line through a subsidiary body; this company also works the whole on account of the Katanga Company. It owes its existence to a decree of October 30, 1906, and is of a remarkable character: its capital is only two millions, and the funds for construction have been provided to it by the State, which merely uses it as an agent. The Company, however, obtains valuable concessions, a guarantee of 4 per cent. interest, and the right to work minerals in the basin of the KasaiSankuru, enjoying 50 per cent. of the profits. In addition to its participation in the affairs of the Katanga Company, the Company is charged with the construction and working on account of the State ${ }^{2}$ of a line from the Katanga railway to Dilolo, the point on the frontier reached by the Portaguese railway from Lobito Bay, and of a line to unite the Katanga and the Lower Congo. To prevent friction between the three great routes to the coast, which will thus be ulti-

1 At which point the Congo becomes more or less navigable down to Kongolo. The length of the line is 534 kilomètres.,

2 The Company is to share equally in the profits. 
mately open to Beira, to Lobito Bay, and to the Congo mouth, a convention was entered into in $1908^{1}$ providing for the division of receipts among the three lines, according to mileage run, for a period of sixteen years, the agreement, however, to become null and void if a new line is created. The gauge of the line, which recently was completed to Bukama, is 1.067 mètres, in harmony with the Rhodesian and Portuguese Junction lines.

The question of further railway development naturally raises difficult issues: the completion of the route by rail and water from the Katanga to the Congo mouth provides an outlet for the products of the Katanga which is entirely Belgian, but the length of the way, 859 kilometres of railway and 2,770 of river with the necessary transhipments, precludes any idea of successful competition with either the Beira route, which could be accelerated by establishment of direct communication between Broken Hill and Salisbury, or the route by Lobito Bay, which must sooner or later be constructed under the existing agreements. ${ }^{2}$ Moreover, the route from Dar-es-Salaam might, esperially if the future should see Belgium established at Ujiji-and Kigoma, compete seriously for some purposes with all these routes, especially as there are coal deposits in the country opened up by the line from Kabalo to. Tanganyika. It is accordingly contemplated to construct a line which shall connect Elizabethville direct with the line from Matadi to Leopoldville via Bukama and Thysville in the valley of the Inkisi on the latter line, while a second project contemplates the construction of a line from Pania Mutombo, where navigation via the Kasai normally ceases, to Mpweto on Moero, and thence to the south of Tanganyika. In either project there are obvious advantages, but the funds must be provided by the State and will involve a considerable burden on the resources of the Congo.

1 On March 31 and July 11.

${ }^{2}$ Cf. Baron E. B. d'Erlanger, United Empire, 1917, p. 462 . It is not unnatural that the agreement regarding the Portuguese railway should be rather unsatisfactory now to the colony. 
The treaty with the United Kingdom of $1906^{1}$ permits the construction by an Anglo-Belgian company of a line from the frontier of the colony to the navigable channel of the Nile near Lado, but no steps to this end have yet been taken. It is probable that the first step in railway construction in the north-east will be the junction of Stanleyville with Mahagi, the project contemplated in 1899 but then laid aside. Mr. R. Williams, ${ }^{2}$ in the period when he was anxious to carry out the project of .Rhodes for railway communication between south and north, obtained the right from Leopold II to construct a line from the south of the State to the Nile in lieu of the construction of a line from Broken Hill to the south of Tanganyika, and from the north of Tanganyika to Kivu, as was once contemplated by Rhodes. The difficulties of country between Mahagi and Rejaf are apparently such as to render direct communication impossible, though the running of a line along the Congo-Nile watershed to Mahagi might be practicable, but none of these proposals have much direct interest for the colony, which is anxious to retain its trade for the western coast.

In the Lower Congo, between the river and Chiloango in the French Congo, the Mayumbé Railway Company was authorized by a decree of July 30, 1898, to construct a line, now of 137 kilomètres, which is worked by the State.

A question of some interest, which has been discussed in Belgium, arises as to the position of the government of the colony under the Berlin Act with regard to railway construction. Article XVI of the Act expressly lays down that on roads, railways, and lateral canals, which may be constructed for the purpose of remedying the innavigability of parts of the river and its affluents, or making good imperfections, there may be levied only tolls calculated on the cost of construction, maintenance, and management, and on the profits due to the promoters, and, as regards the tariff

${ }^{1} \mathrm{Cd} .2920$.

${ }^{2}$ United Empire, 1917, p. 450. This contract fell through, as Mr. Beit desired too large a share in the minerals of the Katanga. 
of these tolls, strangers and the natives of the territories are to be put on a footing of perfect equality. The provisions in question, though expressed to conform with the rules applied to river navigation proper, which is regulated by Article XIV of the Act, present a certain deviation: the rules laid down in the earlier Article make no reference to the profits of promoters, and evidently contemplate normally governmental action, though not excluding that of companies. There is nothing, however, in the terms of the Article regarding railways to deny to a government the right to promote a railway on its own account, but it may fairly be argued-and M. Touchard ${ }^{1}$ has adopted this view - that a government could not take for itself a larger profit on the working of railways than would cover the fair cost of maintenance and working, with the addition of the normal rate of interest on the capital involved which would normally be fixed by the amount paid for it by the government concerned. In the case of a company the rate of profit could hardly be regulated in any simple manner : the risk of failure must be compensated for by substantial profits, as has in fact been the case in regard to the railway from Matadi to Leopoldville. The arrangement which has been made by the State with the Compagnie du chemin de fer du Bas-Congo au Katanga, and which contemplates that the State shall share equally in the profits of the working of the lines entrusted to its construction, may be regarded as not exempt from criticism in this regard, and little more than an effort, under the guise of a company, to secure for the State profits which are forbidden in principle, if not in terms, by the Berlin Act. The position thus produced presents doubtless some inconvenience to the State, but plainly it would be in the best interests of the State if the plan of construction at government cost and working by the government were frankly adopted, the State taking only such profits as can fairly be regarded as interest on the capital advanced, but gaining from the development of the territory.

${ }^{1}$ Les Communications par chemin de fer et par voie fuviale au Congo belge, pp. 18, 19. 
This-prospect, however, is naturally rendered somewhat uninviting by the fact that in neighbouring colonies railways yield a valuable part of the governmental revenue.

Not unnaturally the roads in the Congo have been neglected in comparison with other means of transport, and in few places are there any but native paths along which goods must be carried by porters. Efforts in the Uele district to create motor roads have not been a marked success, but some caravan routes have been opened up in the Katanga. Each chiefdom is under obligation to keep in order the main routes, to provide bridges or other means of crossing streams, and to maintain in the chief place of each district a rest house provided for the use of European travellers. ${ }^{1}$

The postal service of the Congo with the outer world is governed by the provisions of the Universal Postal Union, ${ }^{2}$ and an internal postal service has also been established which has the right to make use of every established form of transport for the free carriage of its letters. Telegraphic communication has been secured by imposing on the railway companies the duty of erecting lines along their routes, while a government system ${ }^{3}$ runs from Leopoldville to Coquilhatville and Stanleyville, and from Kasongo on the Lualaba to Uvira on Tanganyika ; moreover, wireless telegraphy has proved successful in the colony, and has been widely extended. The telegraph system is also connected with the submarine cable at Libreville through the French Congo.

Before the war the three ports of the Congo, Banana, Boma, and Matadi, were served by four companies, the Compagnie belge maritime, the Chargeurs réunis, a French company, which arranged with the Belgian firm for a service every ten days, the German line of Woermann, and the firm of Elder Dempster \& Company. In 1912 the tonnage.

1 Decree of May 2, 1910, Art. 24.

${ }^{2}$ Adherence notified, as required by the Berlin Act, on September 17, 1885.

${ }^{3}$ Carried out under a decree of November 27, 1893. 
of British shipping entered at Boma was 111,950 as against 63,886 in 1913 ; the German figures were 67,579 and 60,748, the Belgian 199,781 and 164,322, and the French 68,249 and 69,494. ${ }^{1}$ Occasional calls are made by Dutch and Portuguese steamers, and the strength of the German interest was due, as on the rest of the. West African coast, to the effectiveness of their working understanding with the British firm. After the war a new feature will emerge in the shape of the competition of Lobito Bay with Beira and the Congo for the trade of the Katanga. The completion of the railway to the Portuguese coast will lessen the journey to England by 2,000 miles, and all the efforts of the Congo companies, and of the Beira and Mashonaland Railway Company will be requisite if this obvious advantage does not deprive them of the greater portion of the trade of the Katanga. The latter company has recently manifested energy in the effort to retain the trade of the Katanga ${ }^{2}$; on January 1, 1913, it took over the control of the line between Broken Hill and the Congo border, on which the charges had been often thrice as high as on the rest of the system, and from January 1, 1914, it reduced its charges on certain classes of goods, very largely diminishing, for example, the charge on cotton blankets, beads, and limbo for native use from $£ 14 s$. $3 d$. to $17 s .10 d$. per $100 \mathrm{lb}$. in order to enable the merchants to tempt the natives to bring their rubber to Elizabethville and to transport it to Beira and not to Boma.

\section{Industry.}

Much of the Congo consists of forest or swamp, or rocky hills covered by bush, which forbid the possibility of agriculture. ${ }^{3}$ The native's wants in a primitive state are few, and the manioc and palm oil, which are his chief needs, are easily supplied. The climate does not conduce to labour, and his social system unhappily makes him despise agri-

1 Cd. 7048-77, p. 16 ; Cd. 7620-103, p. 10.

${ }^{2}$ Cd. 7048-120, p. 4.

${ }^{3}$ See Johnston, George Grenfell, ii. 600 sq.

Q 2 
cultural work and leave it to women or domestic slaves. In some districts, however, considerable skill has been acquired: in the Upper Congo rice is profitably cultivated, apiculture flourishes on the Kasai, and cattle-breeding near Kivu. Other industries are hampered by difficulties of transport; thus, though the Mayumbe railway has opened up a considerable area for forestry, not only have the natives shown execrable workmanship and incorrigible laziness, ${ }^{1}$ but the cost of transport has stifled operations, while on the other side of the boundary the Portuguese can cut the trees and float them down the Lukula to Landana.

The most important product of the Congo is rubber, whose collection was so stimulated by the action of the State in becoming commercially interested in its production that the export rose from fifty tons in 1895 to 6,000 in 1903, representing five-sixths of the exports. In the period after annexation there was necessarily a fall with the abolition of the servile system, and in 1913 the export was only 3,475 tons. $^{2}$ In that year also the price of rubber fell about 50 per cent. ${ }^{3}$; the Government were compelled to forgo the export duty, ${ }^{4}$ and the railway and steamship companies to reduce their charges to prevent disaster; at the same time it was found necessary to fix at $1 \mathrm{fr} .50 \mathrm{c}$. the price to be paid to the natives, and to reject wet and immature rubber. The check to rubber production thus caused turned to the advantage of copal, ${ }^{5}$ the demand for which for varnish had increased since $\overline{1912}$. A native market was opened by the Government at Basankusu, the capital of Lulonga, where rubber is scarce, and a fixed price according to grades was paid, with the result that by the end of 1913 the natives were showing their readiness to work for good wages by bringing in large quantities of copal, yielding a total export of 4,613 tons as against 845 in $1912 .{ }^{6}$ The cocoa industry

1 Cd. 7048-77, p. 13.

${ }^{2}$ Cd. 7620-103, p. $3 ; 2,972$ tons in 1916.

${ }^{3}$ From 10 francs to 5 francs a kilo for tree rubber.

4 An Ordinance of August 20,1913, removed all duty on rubber when the price was not above 5 francs for tree and 3 francs for grass rubber.

${ }^{5} \mathrm{Cd} .7620-103$, p. 5.

6 8,548 tons in 1916. 
introduced in 1900 flourishes mainly at Mayumbe, but it has not yet attained any substantial proportions. Cotton, coffee, sizal, and jute are still in an experimental stage, and the production of manilla hemp requires expensive machinery and considerable expenditure of capital. On the other hand, definite success has attended the efforts of Messrs. Lever's firm, Société des huileries du Congo belge, ${ }^{1}$ to develop the industry of extracting palm oil. Under a concession from the Government the firm has factories on the Kwilu, Kwengo, and Koo rivers, at Alberta, near Bumba, and at Elizabetha, above Barumbu: its activities secure regular employment for thousands of natives, for whose welfare it cares, and it has to its credit the construction of a steam tramway of twelve kilomètres at Alberta. In the Katanga, on a limited scale, there has been tried the experiment of the establishment of European farmers for the purpose of creating a resident white population, such as exists in Rhodesia, but the venture of the Compagnie foncière, agricole et pastorale du Congo (1909-12) ended in failure, the Company surrendering to the State the 150,000 hectares granted to it, upon which the promoters had purposed to establish a Benedictine monastery, and the future of such farming as is proposed is still problematical.

The trade in ivory became in effect a trade monopoly in 1891, and for a time before it had fallen in great measure into the hands of State agents. Antwerp, which in 1889 first received consignments, by 1907 surpassed London as a market with a sale of 312,000 kilograms as against 241,000. The industry is inevitably a declining one, though the Government has fostered it of late by the reduction of its claim to half of all the ivory found, and by reducing the weight of tusk which may be exported from ten to six kilograms. $^{2}$ The export in 1916 was 351,462 kilograms.

The assistance given to agriculture by the. State was meagre - the Department of Agriculture, created by a decree of June 18, 1894, was mainly concerned with the produce

${ }^{1}$ See Cd. 5465-173, pp. 11, 12 ; Cd. 7048-77, p. 11.

2 See decrees of March 15,1910, and April 26, 1913; Cd. 7620-130, p. 7. 
grown in the State plantations ; in 1900 an experimental garden was established at Eala, supplemented by the Botanic Garden at Laeken, where investigations were made as to methods of cultivation and the possibility of introducing new varieties of plants, especially from the Dutch possessions. A far more elaborate system has been created by the Colonial Government, ${ }^{1}$ under which the territory is divided into six divisions, each in charge of an agronomist with an efficient staff, who advises the natives and Europeans as to methods of cultivation, and under whose direction experiments are carried out in methods of cultivation, the introduction of new plants, and the improvement of the breeds of cattle, the domestication of the elephant and similar other wild beasts. The Government has also regulated hunting, ${ }^{2}$ for which permission, whether collective or individual, is necessary : certain classes of animals receive protection, and a reserve for elephants has been created in the Uele. ${ }^{3}$ The natives may hunt in the vacant lands of the State, but not on private land, unless it is subject to a customary service of hunting. Fishing is permitted without special permit, but the use of poison and dynamite are prohibited, ${ }^{4}$ and the Government has endeavoured to develop the industry both on the Lower Congo and on the Great Lakes.

The importance of the mining industry in the Congo is I a product of recent years. By a decree of June 8, 1888, the Government reserved to itself absolutely all the minerals, including mineral oil, in the territory, leaving to the natives the right to work for themselves surface mines on territory actually in their occupation. A further decree of March 30, 1893, provided for the grant of permits to prospect, and the grant by decree in each case of concessions. As a matter of fact, the provisions of the decree which limited grants to

${ }^{1}$ Royal arrêté of January 16,1911, and ministerial arrêté of January 18, 1911 ; Cd. 5465-173, pp. 7, 8.

${ }^{2}$ Decree of July 26, 1910; Ordinance of December 6, 1912 (Congo); Ordinance of September 13, 1913 (Katanga).

${ }^{3}$ Ordinance of April 24, 1911, and December 26, 1911.

${ }^{4}$ Lannoy, L'Organisation coloniale belge, p. 192. 
10,000 hectares were in effect superseded by agreements made with the companies by which researches have actually been carried out in the north of the territory, the Societé internationale forestière et minière, Compagnie des chemins de fer du Congo supérieur aux Grands Lacs, and Compagnie du chemin de fer du Bas-Congo au Katanga. Outside the / Katanga, however, the Congo is not rich in precious metals ; there is gold worked by the Government itself at Kilo and Moto, and the country which may be opened up by a line to Mahagi from Stanleyville is believed to be rich in gold; discoveries of the metal have been made at various points, especially at Bonalia in the Stanleyville district. The Société internationale works mines in the Uele and Aruwimi; a royal order of February 27, 1911, confers on them for ninety-nine years the right to exploit gold, hematite, and magnetite in 20,000 hectares on the Tele, an affluent of the Itimbiri. In the Kasai district and the adjacent part of Angola the same Company works diamonds, sending 8,000 carats to Antwerp in November, 1913, and yielding 80,000 carats in 1916. There is also iron near Kivu, and the Manbettu are noted as workers in this metal.

It is in the Katanga, however, that real mineral wealth abounds. The old régime kept the country rigidly closed to all comers, the Comité spécial reserving concessions to bodies over which it had control. The new régime was speedily faced with demands for prospecting and exploiting rights, and the Government decided to legislate over the heads of the Comite, though not actually against its wishes. ${ }^{1}$ A decree of December 16, 1910, established rules regarding prospecting and concessions under which the power of granting them rests with the Comité, subject, however, to approval by decree of any actual concession or promise to grant one. A general permit to prospect is issued for two years on payment of 100 francs ; if the prospector thinks he has made a discovery he can obtain for the same period, on payment of 200 francs, a special permit, enabling him to carry on intensive research, and exclusive for two years, in

${ }^{1}$ Lannoy, op. cit. p. 162, n. 1. 
a circle with a maximum radius of 500 mètres for precious minerals and stones, and 2,500 mètres in other cases. This permit gives the right to demand a permit of exploitation, and therefore must be approved by decree to be valid. When the holder is ready to begin exploitation he must apply for a permit of exploitation, the area of which will be the square inscribed in the circle included in the permit to prospect. This permit must be granted if he can show that he has the necessary funds; the Comite is then entitled, in the case of an individual exploiter, to 33 per cent. of the profits, and in that of a Company to 33 per cent. of the shares, being also authorized to subscribe for 20 per cent. of the shares if it desires, thus securing control of the Company: in addition the Comité receives annually 5 per cent. of the gross value of the product of the mine, and is represented on the management by a delegate. Another decree of December 23, 1910, closed certain areas definitely to prospecting, but a decree of May 27, 1913, opened the larger part of the Kundelungu area to prospecting for diamonds and precious stones, and the Mandoko for prospecting for all purposes.

As is inevitable, the Union minière, with its longer history and its privileged position as holder of exclusive rights in large portions of the richest mineral-bearing country, is by far the most important establishment. The output for 1913 was 7,400 tons of pure copper from 60,000 tons of ore, and it was claimed in 1917 that it was able to turn out 30,000 tons of copper a year, with prospects of rapid increase. ${ }^{1}$ The Company has also discovered tin at Bukama: gold exists at Mandoko in the extreme south, tin at Kiambi, diamonds on the Kundelungu plateau, and coal in the Lukuga valley traversed by the railway to Tanganyika, ${ }^{2}$ a fact which may have motived the efforts of Germany in

1 R. Williams, United Empire, 1917, p. 449 ; Baron E. B. d'Erlanger, p. 461 , puts it at 46,000 tons; 100,000 tons is looked forward to with confidence ; in 1916 it was 21,560 , value $63,895,691$ francs.

${ }^{2}$ On minerals in the Katanga see Cd. 6665-123, pp. 6, 8; Cd. 7048-120, pp. 8, 9 . 
August, 1914, to seize this part of the territory. Other large concessions besides that of the Union minière exist: two were approved by decree with some hesitation in 1912, the first with the group representing the Comptoir national d'escompte of Paris and the Société générale, and the other with the Brussels branch of the Deutsche Bank, an interesting example of the advance of German interests in the Congo. ${ }^{1}$

The Comité, no longer enjoying any administrative powers, has no authority to deal with any questions affecting the security of the workers or the policing of the mines, which rest with the local government and are entrusted to the Inspectors of Commerce and.Industry created for the Katanga by an Ordinance of April 20,1912, who act at the same time as supervisors of labour and overseers of the execution of the regulations in force to secure the safety of the workers. Enactments have been issued in the Katanga requiring returns of accidents occurring in industrial establishments, ${ }^{2}$ regulating the conditions of work in unhealthy or dangerous places, ${ }^{3}$ and prescribing rules for the working of engines, boilers, and boats propelled by steam power, ${ }^{4}$ and in the rest of the Congo regulations ${ }^{5}$ have been issued by the Governor-General regarding working conditions in dangerous, unhealthy, or unsuitable premises. Further effect has been given to these enactments, which, having been issued under the restricted authority of establishing police offences conferred by the decree of April 16, $1887,{ }^{6}$ could only impose penalties of 200 francs fine and seven days' imprisonment, by a decree of June 4, 1913, which authorizes the infliction of punishment for breach of

${ }^{1}$ Cd. 6606, p. 36. All concessions in the Katanga must terminate at latest on March 11, 1990, when the arrangement between the State and the Company terminates, and the State resumes full control of minerals.

${ }^{2}$ Ordinance of July 25, 1911.

3 Ordinance of September 16, 1911, and October 17, 1912, replaced by an Ordinance of September 11, 1913.

4 Ordinance of June 22, 1912.

${ }^{5}$ Ordinance of February 22, 1912.

Art. 7. 
any regulation established up to fifteen days' imprisonment and 500 francs fine, or both of these penalties. The same enactment also confers on the authorities charged with the duty of supervising labour contracts and the control of dangerous, unhealthy; or unsuitable premises, the right of entering any workshop or building of any kind and investigating the conditions prevailing, while the heads of these establishments, their representatives, and the workmen themselves are placed under obligation to afford the inspectors any information which they desire as to the carrying out of the regulations imposed. Failure to comply with the law involves similar penalties to those provided in the case of breach of regulations, and the heads of establishments are given an interest in securing the carrying out of the regulations by being made civilly responsible for the fines imposed on their representatives for infractions of the law.

There is little other industrial legislation yet in force: trade marks ${ }^{1}$ and patents ${ }^{2}$ are, however, regulated on the usual principles.

\section{Commerce.}

It was contemplated, when the Berlin Act was agreed to, that the Congo would be opened up by the commercial activities of the contracting powers without special favour for any nationality, but of all the hopes which have been defeated in the Congo this perhaps has been the most signally disappointed. A decisive step was taken in this direction when the Compagnie du Congo pour le Commerce et l'Industrie was founded by the efforts of Capt. Thys, for it was inspired by the most ardent Belgian nationalism, and successfully intervened to prevent the consummation of the proposal to entrust to a Company, in which there were large British interests, the work of constructing the Congo railway to Stanley Pool." The Compagnie itself extended its efforts

\footnotetext{
1 Decree of August 26, 1888, and various arrêtés.

2 Decree of October 29, 1886, and various arrêtés.

3 Masoin, Histoire, i. 361, 362.
} 
on every hand : by 1891 it had six affiliated companies, and a capital of 35 million francs, with 24 establishments, employing 250 white men and owning 11 steamers. $^{1}$ In the same year the definite establishment of the Katanga Company with its third share in the lands of the Katanga and the decree of September 21 marked the beginning of the plan of developing the territory by proprietary companies, in which the State was largely interested. The State, which had remained without any share in the profits of the railway from Matadi to Leopoldville, now became a partner in the railway enterprises which it permitted and which it favoured by concessions. It undertook the working of the lands granted to the Great Lakes Company, it became largely interested in the Abir, the Société anversoise du Commerce, the Comptoir commercial congolais, the Compagnie du Lomami, the Société internationale forestière et minière, the American Congo Co., the Société anonyme belge, \&c. To that part of this activity which was concerned with railway development pure and simple no objection could seriously be taken, nor was its action as regards mineral exploitation open to much censure: the evils which arose were derived directly from its concern with the exploitation of rubber and other agricultural products, whose appropriation ran directly counter to native rights.

- The gains which accrued to the King himself up to 1907 have been estimated with plausibility as not less than 100 million francs, ${ }^{2}$ and it is certain that Belgium also profited largely by the new policy. The rubber exports, almost negligible before the new régime, were transformed into a most valuable trade, and the exports rose from two million in 1887 to fifty-eight million in 1906 : imports grew from nine million in 1893 to twenty-one million in $1906 .^{3}$ The share of Belgium in the total trade, which was nil in 1887, rose to 50 per cent. in 1893 and to 72 per cent. in 1897. It was calculated that up to 1893 the State and

1 Ibid. i. 63, 64.

${ }^{2}$ Johnston, George Grenfell, i. 451.

${ }^{3}$ Masoin, op. cit. i. 61 ; ii. 413 ; Payen, Belgique et Congo, pp. 33 sq. 
the companies had purchased sixty million francs worth of merchandise from Belgium and had paid twenty millions to their agents and employees. The agreements with the railway companies and the Union minière compelled them to procure their machinery from Belgium, despite the lower prices payable elsewhere. After annexation the process continued: Belgium normally receives 85 per cent. of the exports; Belgian imports into the Congo rose from 19,700,000 francs in 1908 to $35,900,000$ francs in 1912 ; the total sum of money received by private persons and officials in the Congo and transferred to Belgium had increased in 1913 to over 13,000,000 francs, and the combined surpluses of the Congo companies in that year exceeded $16,000,000$ francs. More than 10,000,000 francs were expended at the same time by the administration in Belgium, where over 200 industrial undertakings have been created to meet the needs of the Congo. The Belgian Government itself derives not an inconsiderable profit from the duties levied on the registration of colonial companies.

In the import trade the most interesting feature is the determined effort which was begun by Germany in 1911 to gain control of trade in the colony. In that year Hamburg agents began a campaign which resulted in ousting France from her former place as third in the list of countries sending exports, Belgium coming first with 65 per cent., the United Kingdom second with 12 per cent., and Germany third with 5 per cent. ${ }^{1}$ In 1912 the effort continued with such success that the British share dwindled to 10 per cent. and the German rose to 8 per cent. ${ }^{2}$ In $1913^{3}$ there were large increases in imports of textile goods, clothing, perfumery, toilet articles, and provisions, an increase stated by the Consular Report to be 'entirely due to the enormous credits which were given on the easiest possible terms by German firms who apparently determined to capture trade for what it is worth in this colony'. The German method of working was that of sending repre-

${ }^{1}$ Cd. 6665-1, pp. 6, 7. ${ }^{2}$ Cd. 7048-77, pp. 5, 6.

${ }^{3}$ Cd. 7620-103, p. 4. 
sentatives to the different centres to show specimens of their wares and solicit orders, ${ }^{1}$ and in 1912 British goods were meeting with serious competition in German cheap prints. There is, however, a considerable trade with South Africa, including both Rhodesia and the. Union, and the total British imports rose in 1912 to be 17 per cent. of the whole in contrast with 15.8 per cent. in 1911. Of other countries France, Holland, Portugal, and Angola follow in order, but the total of the trade done with them is relatively insignificant.

The goods imported, ${ }^{2}$ apart from iron and steel materials and other requirements for governmental purposes, consist of cheap articles for native use, such as cotton fabrics, loin cloths, blue and white striped prints, indigo blue drill, red scarlet baize, cotton covers, ready-made and second-hand clothing, all of the cheapest kind, a few British sun-hats, straw hats, and German slippers. Germany in 1912 supplied nearly all the perfumes and perfumed soap, padlocks, scissors, pocket knives, imitation pearl beads, mirrors, machetes, and beer. Other articles in demand are matches, pipes from Gouda, condensed milk, biscuits, British or French, Portuguese sardines, Dutch gin, Portuguese wines, Belgian sugar, American or Australian corned beef, American tobacco, Dutch crockery, soap, starch, rice, and Austro-Hungarian flour. The total of the import trade is still relatively inconsiderable in view of the size of the country and its population, but the development of the purchasing power of the natives will doubtless be large, though probably slow.

The policy of the State long discouraged the development of petty trade, and it is small Portuguese traders ${ }^{3}$ who in the main have managed to thrive despite the difficulties of making profits. A great impetus to internal trade has been given by the policy of the Government in introducing coinage and paying its employees in coin, and secondly in

${ }^{1}$ Cd. 7048-77, pp. 9, 10.

${ }^{2}$ Cd. 6665-1, pp. 6-8; Cd. 7048-77, pp. 6-9.

${ }^{3}$ Cd. 7048-77, p. 6. In 1912 one British, one Dutch, one German, and one French firm had stores up country for retail trade. 
discontinuing the former supply of foodstuffs of every kind to its employees, which acted as a most serious bar to the success of petty traders by depriving them of their normal clientèle. Directorates of Commerce and Industry were established at Boma and Elizabethville in 1910 to give commercial information, and the growth of the Katanga has been accompanied by the establishment in that district of agencies of many South Africa houses.

In all commercial transactions, by decrees of August 17, 1910, and January 15, 1913, the only legal weights and measures which may be used in the colony are those provided for by the legislation of Belgium for use in that State.

Freedom of trade is provided for by the Berlin Act: the rate of import duties permissible is regulated by the Brussels Act of 1890, modified as to liquor by the Act of 1906 and as to arms and ammunition by the convention of 1910. There has been but little legislation regulating commerce : a decree of July 26, 1910, provides for the issue of regulations as to the soundness of food offered for sale, and in the Katanga, to prevent famines formerly usual, the chiefs are bound to reserve at each harvest sufficient grain for the sowing of next season's crop. ${ }^{1}$ A decree of March 15, 1910, ${ }^{2}$ provides for the registration of ivory by the finder or any recipient at the first government post available under heavy penalties, a measure necessary to secure the payment to the Government of its share of the value on export, and the sale or export of impure rubber is penalized by a decree of January $7,1911 .^{3}$

\section{Labour.}

During the State régime the chief employer of labour in the territory was the Government or companies working under its aegis, and the source of labour was, for all the

1 Ordinance-Law of April 1, 1912, and decree of July 31, 1912.

2 Amended by a decree of February 26, 1913.

${ }^{3}$ See also an Ordinance of September 5, 1913. 
ordinary work of collecting produce and transport duties of all kind, the natives of the State forced to work either as a direct corvée or in lieu of taxation. With the advent of the new régime this position has definitely passed away, especially since the determination of the Government to confine compulsory recruitment to the armed force, and the exploitation of the country is dependent on the effective recruitment of labour either in the colony or from without. No effort has been made to secure the importation of Indian labour, which would never have been permitted by the Government of India, and the recruitment of men from neighbouring colonies and protectorates has been reduced to small dimensions since the early days of the State. The demand for labour, however, varies enormously in the different parts of the colony : in the north there is comparatively little shortage, and the payment of regular wages has enabled Messrs. Lever to recruit their workers without serious difficulty, but in the Katanga the mines have always suffered from scanty supplies of men, and have been driven to systematic recruiting from without the territory. Experience of the ill success of rival recruiting resulted in the formation by leading companies in the Katanga of the Bourse du travail du Katanga, which received approval by a royal arrêté of September 12, 1910. This institution has had many difficulties to contend with, ${ }^{1}$ and the mixed character of the sources of labour may be seen in the fact that the mines of Katanga in 1913 employed 1,840 natives recruited by agreement with the British South Africa Company in North-eastern Rhodesia, 250 secured by the Bureau, 250 who offered themselves for work from various sources, and 600 contracted for with the Companhia da Nyassa in Portuguese East Africa. ${ }^{2}$ The rest of the natives employed in Elizabethville in that year were mainly from Rhodesia or Nyassaland, and they enjoyed high wages, domestic servants obtaining as much as $£ 5$ a month, while mineworkers started with fifteen shillings. The problem of labour in the Katanga is in close harmony with the same
${ }^{1}$ Cd. 6606, p. 10.
${ }^{2}$ Cd. 7048-120, pp. $8,9$. 
problem on the mines of the Witwatersrand, and must largely depend on developments outside the territory.

The rules for recruitment of natives are laid down by a decree of August 17, 1910, modified by one of January 25, 1912. The right of forbidding recruitment in any area is normally to be exercised only by the Governor-General, and in case of urgency by the Commissioner of a district, whose decision must be approved by the Governor-General within four months, else it lapses. The restrictions on recruiting imposed by the law apply only to engagements to work more than ten kilomètres from the residence of the person engaged, and no person can engage recruits without a permit, which may be withdrawn if the permission is abuised.

The conditions which may be contained in labour contracts are clearly provided for in the case of all contracts between a non-native of the Congo and any native of the Congo or the neighbouring territories, whether matriculated or not. There are excepted, therefore, from control the contracts concluded between Europeans and between natives inter se, and, curiously enough, a native of any territory other than the Congo, when an employer, is regarded as a European. Contracts of service, however, which are not subject to the decree of August 17, 1910, may be submitted to the visa of the authorities, in which case they become definitive agreements, the terms of which cannot be varied by any other evidence.

Any native, whether adult or not, may contract, but those who are being educated under the care of the State, or missionary societies acting for it, must have the authority of their legal tutor. A married woman ${ }^{2}$ must have the permission of her husband or, in default, of a functionary.

${ }^{1}$ This was called for by the action of the Vice-Governor-General of the Katanga, who amended by an Ordinance-Law of August 25, 1911, the original decree; Bulletin officiel, 1912, p. 66.

${ }^{2}$ It is not made clear whether the wives of a polygamist are considered wives in the meaning of the law; cf. Lannoy, L'Organisation coloniale belge, p. 200. 
The terms of the contrast are definitely limited : no contract can be for more than three 'years' duration: if the time is not fixed by its terms or the nature of the work specified, it is regulated by custom, but may not exceed three months. The wages must be paid monthly in cash, and each employee must be given a book showing the rules as to payment of wages and other particulars. In default of special agreement the employer must house and feed the employee; if not, he must pay his wages weekly. In every case the employer must secure that the employment is carried out with due regard to the safety and health of the employee, must give him four days' leave a month, provide for him in illness for a period from fifteen days to a month, and repatriate him on the termination of the contract. If the contract is for a period exceeding three months it must be visa'd by a functionary appointed by the Government, who must assure himself that the employee understands its terms.

The sanctions provided for the fulfilment of the contract are both civil and penal. The former include deductions of wages, not exceeding a quarter of the daily pay, the determination of the contract, and the payment of damages, which, however, cannot be enforced by personal constraint. The penal remedies are justified on the ground that without them it is impossible to secure the observation of contracts otherwise by the natives, and that breaches of contract by employers lessen the respect which should be felt for the Europeans by the natives. ${ }^{1}$ The principle here invoked is one which has parallels in British colonial legislation, not merely in the case of immigrants introduced from great distances at heavy expeuse, but also in the case of local engagements. It is plainly justifiable to punish as crimes breaches of contract which involve serious danger to life or health, as is done by the Indian Penal Code, but the treatment of ordinary breaches of contract as criminal is an inexcusable violation of the rights of the natives, and deprives employers of a most important incentive to fair

${ }^{1}$ Lannoy, op. cit. pp. 201, 202. 
treatment of employees as a means of securing effective work, and recognition of this principle has been shown of late years in the British colonies by the abolition of penal clauses in the laws affecting immigrant Indians, and also in some cases in the laws affecting local engagements. Unhappily this view does not appear to have yet had any echo in the Congo, in which, on the contrary, in part under the influence of South Africa, the tendency has been for increasing disabilities to be placed by law on the natives.

The decree of 1910 provided merely for penalties of fine up to 200 francs and seven days' imprisonment, with the possibility of increase in the fine up to 2,500 francs in the case of breach of duty by the employer. In addition, competence was given to territorial judges, officers of the Public Prosecutor, and other authorities selected by the GovernorGeneral, to hear demands for the fixing of the money value of wages if that were not specified, and for repatriation in cases where the native had by his own fault brought about his dismissal. Moreover, the officers of the Public Prosecutor were authorized to take civil action in the name of natives against employers when necessary. Complaints were, however, soon made in the Katanga that the penalties were of no value as the natives could not be imprisoned as a preventive measure, and by simple flight evaded. any punishment. The Vice-Governor-General of the Katanga accordingly, by an Ordinance of September 19, 1911, increased the penalties to an extent which permitted under the Congolese penal law preventive detention, but the Minister of the Colonies took just exception to a procedure which imposed ridiculously severe penalties on mere civil delicts. Instead a decree of Februry 9, 1912, introduced the principle of permitting territorial administrators to deal summarily with breaches of contract by natives. A native under the new procedure may, on the request of his employer or his agent, be arrested by any agent of the administration or of the armed force and taken before the judge, who, if he decides that the man is bound by his engagement, may, with or without pronouncing any penalty, send him back 
to his master. ${ }^{1}$ These decisions must be reported to the Procurator of the appropriate area, who may revise the case if the condemnation is wrong in fact or law, or, if the case was not within the competence of the judge, bring it before the proper court. The procedure is, it will be seen, remarkably informal, for much depends on the procès-verbal of each case which the judge is to draw up, and it is plain that it might easily lead to considerable injustice. Nevertheless the complaint in the Katanga is that the native is difficult to control, as he does not mind imprisonment, and that there ought to be the power of inflicting corporal punishment for failure to work. ${ }^{2}$ The existence of such a state of public opinion is important, as it indicates the constant difficulty experienced by administrations in struggling against the innate faith of the settler of whatever origin that the rôle of the native is to serve as a species of slave.

In the Katanga two Ordinances of March 11 and June 21, 1911, provide for monthly returns by heads of establishments employing 100 men or more of the personnel of their staff white and native, and for the keeping of nominal lists of all natives by every employer in the Vice-Government. ${ }^{3}$ An Ordinance of March 10, 1913, exacts an elaborate pass law for such localities as may be from time to time determined.

The difficulties of obtaining labour, especially in the Katanga, are not likely easily to be overcome: the actual size of the population of the Congo is wholly conjectural: the vast figures of Stanley ${ }^{4}$ probably were always exaggerated, ${ }^{5}$ but the State régime can hardly have failed to diminish the number of the residents, and the advent of sleeping sickness contributed powerfully to this result. The

1 Decree of February 9, 1912, Art. 10.

${ }^{2}$ Cd. 6665-123, p. 11.

3 A similar Ordinance for the Congo was issued on October 11, 1913.

4 The Congo, ii. $365(42,000,000)$.

5 Johnston (George Grenfell, ii. 539-46) suggests 15,500,000: in 1910 an estimate was 7,245,000; Cd. 5860, p. 17. 
present total may conjecturally be placed at under eight millions, and, having regard to the existing conditions, economic constraint on the natives to enter into European service is not likely to be felt at any early date. The true policy undoubtedly lies in offering good wages and fair treatment, to which there is evidence that they will respond in course of time. It must be remembered that the past history of the land has been such as to render labour decidedly unpopular as well as to weaken the stamina of the race, while experience both in railway work and in the production of palm products under the aegis of Messrs. Lever, has shown the value of reasonable inducements to work.

The white population only attained on January 1, 1912,1 the total of 5,464 persons as against 4,003 a year before; the growth was of course mainly in the Katanga, where the mining operations have attracted a large influx of South African miners and traders. Belgians then accounted for 3,307 of the population, predominantly officials, British 505, Portuguese 303, Italians 278, Scandinavian 177, German 150, Dutch 129, Russian 117, Greek 102, French 91, Swiss 69, and American 46. About 600 of the population were women, and the death-rate was 38 , a very high figure when it is remembered that many of the population have come to the country in the prime of life after strict medical examination for fitness to live in the tropics. The mortality was greatest from February to April. To remedy the British influx into the south, as has been seen, ${ }^{2}$ experiments in fostering Belgian migration have been made by the Government, but with singularly meagre success.

\section{The Economic Future of the Congo.}

It must be admitted that as yet .comparatively little has been made out of the great economic possibilities of the

${ }^{1}$ Cd. 7048-77, pp. 3, 4.

${ }^{2}$ Above, p. 161. A pamphlet, Belges! Connaissons notre Congo, issued by the Ministry for the Colonies, is an attractive appeal to farmers to settle in the territory ( $J . A$. S. xvii. 328). 
territory. The process of collecting rubber, copal, and ivory has constituted the main industry of the colony, and these are essentially simple operations which drain the country without securing the substitution of new and more abiding sources of wealth. The effect of the State régime has been that vast areas are now exhausted of rubber, and that what remains is inaccessible, while the natives are unwilling to engage in the collection of it, and the future of the rubber industry demands systematic work in replanting. The researches of the Government have shown that Funtumia elastica (Ireh) thrives throughout the country, Manihot Glaziovii (Ceara) in the Mayumbe district, and Hevea braziliensis especially in the equatorial districts. ${ }^{1}$ The success of the Government plantations on a small scale has been marked, but the question of labour is serious. In German East Africa Ceara has been planted successfully by native labour under white supervision, but the profits so made depend essentially on the German methods of securing effective work. ${ }^{2}$

In these circumstances interest attaches to the efforts of Messrs. Lever to develop the palm products industry ${ }^{3}$ by inducing the natives to give full co-operation. The success has been marked, but there are serious considerations which affect the future of the industry. Prior to the war the vast bulk of the palm kernels of West Africa found their way to Hamburg, which received 241,961 tons, worth $£ 5,233,352$, in 1913. At Harburg, near Hamburg, the kernels were subjected to treatment under which they yielded from 46 to 53 per cent. of oil, which by suitable handling could be converted into a liquid called olein, or a hard white fat, stearin. From various admixtures of these two could be manufactured margarine, vegetable butter, cooking fat, and chocolate fat on the one hand, and on the other candles and.soap. The remains of the kernels, after

1 See Cd. 6665-1, pp. 20-2 ; Cd. 7620-103, p. 7.

${ }^{2}$ See Major Christy, J. A. S. xvii. 113-17, and ef. A. F. Calvert, Th German African Empire, pp. 142-59.

${ }^{3}$ See Cd. 8247 ; J. A.S. xv. 320-34; A. H. Milbourne, ibid. xv. 133-44 
the expression of the oil, was manufactured into cake which was a popular food for young pigs, milch-cows, \&c. The German monopoly was the result of various causes: the demand for edible oil products before the war was much larger in Germany than in the United Kingdom, where the oil $^{1}$ was mainly used for soap and candles, yielding less profit than did edible products. The Dutch margarine firms could obtain their supplies of material more cheaply by water from Germany than by sea transport from the United Kingdom. The value of palm-kernel cake as feeding stuff was not appreciated in the United Kingdom, and the German tariff and railway rates both were called into play. to preserve the advantages given by economic conditions. The method of extraction of oil locally adopted by Messrs. Lever has many advantages: it increases the yield of oil, the kernels .being fresher; it economizes carriage, and diminishes the importance of finding a market for the material which survives the crushing, while, on the other hand, there has been a determined effort, not altogether unsuccessful, to introduce crushing of kernels and the use of palm-kernel cake as a means of feeding stock in the United Kingdom also. It is therefore certain that after the war Germany will be deeply interested in seeking to gain a hold on the palm product trade of the Congo, for which she was doubtless paving the way by her activity just before the war in establishing commercial relations with the territory.

No other agricultural product offers at present any certainty of success : manilla fibre and similar products require expensive machinery and large capital for successful production, and cocoa, which elsewhere is important, has not yet proved capable of cultivation on a great scale. Coffee and cotton, as has been seen, are in even worse case. On the other hand, there is obvious a source whence electric power for the railways and the mines alike will doubtless in the future be freely drawn; the great falls on the Congo will

${ }^{1}$ Palm oil has regularly been exported to England from West Africa, and is in steady demand there; cf. Keith, West Africa, pp. 247, 248. 
yield to the application of abundant capital results of high value, but in this case also no rapid development can be looked for, in view of the demand for capital for more enticing purposes which will arise on the termination of the war. From this cause alone the progress of the Congo must in all likelihood be slow, but the experience of the State régime, which erred through its desire to hasten results, is an indication that the essential aims of the territory can best be realized by steady development. It is, of course, possible that the skill of German finance may be able to offer Belgium prospects of advances in return for obtaining economic control of the territory, but the acceptance of such overtures would clearly be suicidal.

In addition to the lack of capital there are other causes which must inevitably delay the work of the development of the colony. The difficulty of communications engendered by the defects of the Congo must not be under-estimated. The charges on the line from Matadi to Leopoldville, even as reduced by the exertions of the Colonial Goverument, remain a serious burden on commerce, increasing the cost of articles by fifty or even a hundred per cent., ${ }^{1}$ and the charges for conveyance by steamer are still high. Reduction in them has been and can be effected by increasing the size of the vessels employed, but this in its turn necessitates the improvement of the channel of the river, involving heavy charges on the State. In the Katanga, of course, saving can be effected by the use of the Beira, and eventually of the Lobito Bay route, but it is natural that the State should be anxious to preserve to the Congo as much of its trade as practicable.

Finally, the character of the labour supply must always present great difficulties. The Congolese native, so long oppressed and ill-used, has inevitably since his liberation developed a spirit of disinclination to work which has unfortunately also been accompanied by the manifestation of a spirit of insubordination and insolence to Europeans, on which British as well as Belgians have unfavourably com-

${ }^{1}$ On these rates ef. Cd. 6665-1, pp. 10-12. 
mented.' But, while it is easy to deplore the position, it is extremely difficult to devise any remedy which will not reintroduce under a change of form the old evils of compulsory service of the State régime. Ruling out either direct or indirect compulsion, there remains only the path of affording inducements for honest work, and this has been followed with success by Messrs. Lever in their enterprise. It is possible also that success might be achieved if the Government were to experiment with the grant of domain land, not merely to groups of natives, but also to individuals ; the necessity of communal cultivation clearly renders the inducement to energy in this regard minimal, and there is no ground for assuming that the magic of personal property might not have its effect among the natives, when they knew that they would have security of enjoyment of the work of their hands. The control exercised by the chief over the movements of his tribe is also a bar in the path of progress which might be modified: it enables a chief ${ }^{2}$ to prevent men undertaking work away from the chiefdom which would enable them to attain a better position except on terms which deprive them of the main incentive to work. The development of the system of matriculation of natives appears also necessary, in order that there may be gradually produced a middle class of natives distinctly above the present level of intelligence and wealth. Yet another desideratum, if Egyptian experience may be trusted, is the establishment of an agricultural bank, without which the taking up of new land by the natives will hardly be effected.

${ }^{1}$ Cd. 6606, pp. $10,11,54,5 \dot{6}$.

2 The territorial administrator can, indeed, grant permission despite the chief, but clearly this is a difficult power to use (decree of May 2, 1910, Art. 6). 


\section{CHAPTER XVIII}

\section{THE CIVIL AND PENAL CODES}

\section{Civil Law and Procedure.}

No effort has been made in the Congo-as recently with no small success in Morocco-to devise a code of civil law which would adapt the principles of the Code civil to native circumstances : any such effort would be fruitless in view of the fact that the Congo possessed before the Belgian occupation no such definite code of law as would render an effort to merge native and European law appropriate. Nor has it been thought necessary to elaborate a complete code even for the regulation of the civil relations of non-natives, and the so-called Code civil of the Congo is no more than a series of decrees dealing with the topics which are regulated by the civil code of Belgium.

A decree of May 4, 1895, established the principle that all matters affecting the status and capacity as well as the family relations of any foreigner are regulated by his own national law, unless that is contrary to public order or Congolese legislation having in view the interest of society and public morals. The provisions of the Code civil, therefore, which deal with these topics have effect only on matriculated natives, who are subject to the written law when it exists, and in other matters to customary law, by which the affairs of the non-matriculated natives are regulated. ${ }^{1}$

Registers of civil status are kept by such officials as may be designated by the Governal-General from time to time. ${ }^{2}$ Births, deaths, and marriages must be registered, and a civil celebration is necessary for the validity of marriage, though

1 Charter, Art. 4.

${ }^{2}$ Decree of May 4, 1895, Arts. 16, 17. 
under a decree of June 3,1906 , Catholic priests may receive on application the power to perform the civil service for those whom they have already married by a religious form. The minimum age of marriage is fixed at 14 for a boy, 12 for a girl: if under 16 years the permission of the father, whom failing the mother or tutor, is necessary: in the case of children brought up under the care of the State or by missionaries under its authority, the head of the establishment must give consent until the age of 18, that fixed for the liberation of these children, is attained. The form of celebration ${ }^{1}$ is modelled on that in force in Belgium. The effect of marriage on the persons of the husband and wife is regulated by the law of the husband's nationality at the time of celebration of the marriage, that on the persons of the children by the law of his nationality on their birth, and questions of property are regulated, in the absence of a nuptial contract, by the law of the place of the first settlement of the married pair. ${ }^{2}$ Divorce is permitted either on grounds or by mutual consent: where it is permissible, a judicial separation may be applied for. Foreigners can only obtain divorce if their own laws permit it. The paternal authority may be taken away by a court if misused: minority extends to the age of 16, or 18 or earlier marriage with due consent, in the case of the children educated by the State: the tutor of a minor is appointed by the last surviving parent or by the court, which may, if it think fit, appoint a family council. Affiliation, adoption, and interdiction are regulated much as in Belgium.

Domicile is regulated by the usual principles: it is expressly provided, ${ }^{3}$ however, that the domicile of a government department is at the seat of the administration and of a foreign company at such place as it may choose in the colony.

The law of property has been codified in its main outlines by decrees of July 31, 1912, and June 30, 1913, destined to

1 1bid. Arts. 104-9.

${ }^{2}$ Ibid. Art. 12.

3 Decree of May 4, 1895, Art. 60. 
serve as a convenient guide to the legal officers of the Government. Rights are divided into contractual rights, real rights, and intellectual rights, which are defined: it is noteworthy that while a right of occupation is recognized it is not classed as a real right. ${ }^{1}$

Succession on intestacy remains regulated by the law of the nationality of the deceased : inheritances unclaimed for five years lapse to the State, which is only required to notify the existence of the estate by notification affixed to the door of the court. ${ }^{2}$ If, however, the heirs are known to be outside the colony or far away from the property in question, the Royal Procurator or his delegate is required to take the necessary measures to prevent the loss of the property. Provision is also made ${ }^{3}$ for restoring to the customary heirs any property of natives dying in urban areas, the chief receiving the property in default of other heirs. Wills are regulated by the principle that the form is regulated by the lex loci, though a foreigner may use the form approved by the law of his nationality, which governs the effect of the will.4 The other provisions of the Congolese law of property are borrowed largely, without much discrimination, from Belgian law. The Colonial Treasury is given a preferential claim on the immovable estate of any person in the territory for the current and preceding year's taxation, but it does not appear whether his privilege ranks above a prior mortgage. ${ }^{5}$

The commercial legislation of the colony is scanty : the creation of commercial companies is subjected to very few restrictions, ${ }^{6}$ but limited companies must be authorized by administrative decree. The constitution of the Society

\section{Art. 12 of the decree of 1912.}

2 Arrêté of July 31, 1891, under a decree of December 28, 1888.

3 Circular of June 24, 1899.

4 Decree of February 20, 1891, Art. 10.

5 Decree of March 17, 1910, Art. 28.

${ }^{6}$ Decree of February 27, 1887. The definition of commerce and proof of commercial engagements are regulated by a decree of August 2, 1913 ; Bulletin officiel, 1913, pp. 766 sq. 
must, however, be deposited with the Registrar of the Court and published in the Bulletin officiel. Foreign companies are only required to publish an extract from their statutes giving details of the objects of the company, its capital, shareholders, management, and naming a place in the colony where notices may be served upon it. These rules, however, apply only to commercial companies in the technical sense: other companies, pastoral or agricultural for instance, must be formed in the colony under the same easy conditions as apply to commercial companies. ${ }^{1}$ No company may hold more than 10,000 hectares of land without special authorization. $^{2}$

A decree of July 31,1912 , imposes on all commercial firms and commercial companies of all kinds the obligation of keeping regular accounts of their financial and other transactions, and of preserving for ten years their correspondence, and prescribes the conditions on which these documents can be made available in legal proceedings. Provision is made for the bankruptcy of a commercial firm, by order of a court of First Instance, on the request of the firm, or a creditor, or the Public Prosecutor, and the appointment of a curator of the assets. ${ }^{3}$

The civil procedure is simple and summary ${ }^{4}$ : persons residing outside the colony or at a great distance from the scene of any suit can by application to the Director of Justice have a mandatory appointed to prosecute or defend actions on their account. ${ }^{5}$

The relations between the Belgian and colonial courts are regulated as regards civil procedure by Article XXIX of the Charter, which renders judgements in civil and commercial cases of the tribunals of the metropolis entitled to execution in the colony: the same rule applies to arbitral

${ }^{1}$ Decree of May 4, 1912.

${ }^{2}$ Decree of February 27, 1887, Art. 12.

${ }^{3}$ Ordinance of September 21, 1886, approved by decree of March 18, 1887.

4 Decree of May 14, 1886.

${ }^{5}$ Decree of March 21, 1893. 
awards and to legal requisitions. On the other hand, the Belgian Parliament declined to accept the same rule as applicable to Congolese judgements : these are entitled to execution only on condition that they contain nothing contrary to public order or Belgian public law ; that they have in the colony the effect of final judgements submitting of no appeal ; that the copy of the judgement complies with the requirements of the colonial law regulating its validity; and that the rights of the defence have been respected. These are the same conditions as are applied in Belgium to foreign judgements in the case of States with which treaties regulating these matters exist, and the slur on the competence of the colonial courts is obvious and indefensible. ${ }^{1}$ The colonial courts accord more favourable treatment than does Belgium to foreign judgements, for it accepts them subject merely to their being final, and to the production of duly authenticated copies. To these rules there is one exception: the decisions of the Conseil supérieur sitting at Brussels are accepted as ipso fucto valid in Belgium. Legal requisitions from the Congo are to be executed in Belgium if the dispositions whose execution is asked for do not contravene public order or Belgian public law, and if duly authenticated copies are supplied.

\section{Criminal Law and Procedure.}

In $1896^{2}$ an attempt was made to produce a complete code of the penal laws of the State, but the collection then issued as the Code pénal was imperfect and has since been supplemented by many enactments. ${ }^{3}$ The code is based on the Belgian law, with efforts to simplify it for application to the territory. Thus the code ignores the distinction of offences as crimes, delicts, and contraventions on which the Belgian

${ }^{1}$ Lannoy, L'Organisation coloniale belge, pp. 276, 277.

2 Decree of December 2, 1896, and Code pénal of December 19, 1896.

${ }^{3}$ Arrêtés of May 16 and July 29, 1899; decrees of August 1, 1897; June 2, 1898; February 8 and October 6, 1906. 
code is based, and it recognizes only one form of imprisonment, which may extend for lif'e or to one day only. The maximum fine is fixed at 5,000 francs, whereas there is no limit in Belgium : in both the minimum is placed at 1 franc. The penalties of interdiction and placing under police surveillance are not admitted. In the assignment of penalties it limits more severely the discretion of the judge; if there are extenuating circumstances, the right to lower the punishment is more restricted than in Belgium : the least penalty that may be inflicted is half the minimum sentence for the crime; in the case of death the alternative must be imprisonment for ten to twenty years or for life; if the sentence is imprisonment for life the substitute must be imprisonment for ten to fifteen years. If there are several violations of law in one offence, only the highest penalty applicable is to be inflicted, accumulation of penalties not being permitted as in Belgium in the case of offences less than crimes. No provision is made for increased penalties for repetition of criminal practices. In the matter of conditional liberation, moreover, it is less strict than the Belgian law, for it permits liberation after a quarter only of the sentence has been served, or after five years in the case of life sentences in lieu of the third of the sentence and ten years required in Belgium. ${ }^{1}$

Criminal procedure is regulated by a decree of April 27, 1889. The judge becomes competent to deal with an accusation by the citation of the accuser or on the motion of the Public Prosecutor. The initial steps are taken by officers of the Public Prosecutor or officers of judicial police. Preventive detention, save in the case of flagrant delict, can be ordered only by the Royal Procurator or a judge, and must be confirmed every fifteen days by a judge, but these precautions in the interest of individual liberty do not apply to cases of offences against the public peace and order. ${ }^{2}$ It rests with the accused to summon his own witnesses for the

1 Lannoy, L'Organisation coloniale belge, pp. 279, 280.

${ }^{2}$ Decree of June 3, 1906. 
defence, an arrangement criticized by Belgian jurists ${ }^{1}$ as inconsistent with the duty imposed on the Public Prosecutor, who is legally not a mere accuser but a protector of innocence.

Whereas English jurisprudence treats crime as normally strictly subject to punishment only by the courts of the place where it is committed, and therefore makes no provision for the trial in England of ordinary ${ }^{2}$ crimes committed in the colonies or vice versa, Belgium has applied the principles of continental jurisprudence, and the treatment of crimes committed in Belgium or the Congo, in the Congo or Belgium, is regulated on a basis of quasi-reciprocity by Article XXX of the Charter. Criminal judgements, whether pronounced in Belgium or the Congo, have the force of a final decision in either country, and are executory without further examination. ${ }^{3}$ But, though in this regard the Charter goes further in connexion with criminal decisions than in regard to civil decisions, it does not permit complete assimilation of jurisdictions. On the ground that the protection afforded an accused is more ample in Belgium than in the Congo, it subjects to certain limitations the handing over to the colonial courts of a.criminal arrested in Belgium for a crime committed in the colony, and it absolutely forbids the trial by a colonial court of a person arrested in the colony on the accusation of having committed a crime in Belgium. In the former case the trial of the accused normally takes place in Belgium, but in accordance with the colonial law, the punishment being altered to accord with the Belgian rules; but, if it is difficult to secure the necessary evidence in Belgium, the Chambre des mises en accusation may at the request of the accused, or by a unanimous vote taken on the motion of the Public Prosecutor, order his return to the Congo. In the latter case the accused must be

1 Lannoy, op. cit. p. 281.

${ }^{2}$ For exceptions see Keith, Responsible Government in the Dominions, i. 136.

3 The actual carrying out of this provision involves many difficulties, on which see Lannoy, L'Organisation coloniale belge, pp. 283-8. 
tried in Belgium, though he is entitled, if he desires to avoid the journey home, and Belgium does not demand his return, to be represented at the trial by a special attorney. The refusal to accord him the privilege of being tried by a colonial court under the Belgian law, at least for less serious offences, is clearly open to criticism, ${ }^{1}$ for it implies a distrust in the competence of the colonial judiciary which is either unjustified or if justified should lead to a drastic revision of the judicial system.

${ }^{1}$ Lannoy, op. cit. p. 283 


\section{CHAPTER XIX}

\section{THE PEACE SETTLEMENT AND THE BERLIN}

\section{$\mathrm{ACT}$}

IT is now possible to express a definite opinion on the question which must be raised at any final settlement of the European War, the moral right of Belgium to retain the Congo territory. There has, as was natural, been some tendency since the war to look back upon the past in the light afforded by the treason of Mr. Casement, whose share in revealing the atrocities on the Congo is exaggerated out of reason, and to assume that the case against the Congo State was largely fictitious and pro-German in character, ${ }^{1}$ a view which has the support of the decided sympathy for Germany manifested by Mr. E. D. Morel, who figured so prominently in the British movement to secure the reform of the administration of the Congo. But no admiration for Belgium or for the undoubted ability of Leopold II can be allowed to obscure the facts of the government of the Congo territory by the State. It was founded with the avowed humane and benevolent object of civilizing the natives of the Congo and affording to European nations the benefits of entire freedom of trade in an area of some 900,000 square miles of territory. Within seven years of its institution it had devised a legal system under which the natives, deprived of the right to collect the natural products of the soil, were forced to labour on the specious plea of taxation for the State or companies in which it was interested, while independent traders, especially non-Belgian, were effectively

${ }_{1}^{1}$ R. Williams (United Empire, 1917, pp. 451, 452) treats the agitation as largely promoted by Germany in consequence of his success in obtaining the arrangement with Portugal for the construction of the Lobito Bay railway. 
excluded from the territory and forbidden the means of acquiring land or carrying on trade.

It has not been possible for Belgium to efface immediately lor wholly the evils of the past régime. Hampered by the tradition of the past in the minds of the servants of the State whom it took over, and by the difficulty of finance caused by the abolition of the former system of exploitation, Belgium has yet much to do before her colonial administration can be regarded as a model, ${ }^{1}$ and, while the national spirit ${ }^{2}$ of her officials is natural and in itself laudable, it must not be forgotten that it accords somewhat badly with the international basis of the existence of the State. Belgian jurists naturally enough lay stress on the fact that the State is not a creation of the Berlin Act, but this is a mere technicality. The recognition which was accorded to the State was given not to Belgium or the King of the Belgians, but to an association claiming to be international, and offering to all comers alike absolute equality of treatment. The British refusal of recognition of the assumption of sovereignty by Belgium until satisfied that the terms of the Berlin Act would be respected is sufficient proof that the Belgian claim has never been, and could never be, admitted by British jurists.

If, however, the Belgian Congo is not more than a fairly well governed colony, and if a lasting injury has been inflicted on the trade of all other nations by the monopoly so long conceded to Belgian trade, the effects of which cannot easily, if ever, be undone, it remains true that no other Power can advance a superior claim to the right to control the territory. France has, indeed, by her right of pre-emption always had a special interest in the future of the territory, and by an unhappy imitation of the Congolese policy for a time ruined the prospects of her own Congolese possession, and inflicted injustice on British trade which can never be entirely remedied. But, while the assent of

${ }^{1}$ Cf. Sir H. Johnston, Journ. Soc. Comp. Leg. xviii. 37, whose praise seems exaggerated.

${ }^{2}$ Cf. remarkable examples in $\mathrm{Cd} .6606$, pp. 50-71. 
the Powers to the original grant of the right of pre-emption may be inferred from their silence in $1884-5^{1}$ or their formal recognition as in the case of Germany, the treaty of November 4, 1911, with Germany expressly provided that the right of pre-emption could not be acted upon without discussion between the whole of the Powers signatory of the Berlin Act. The determination of the treaty of 1911 by the war relieves France from its obligation under it, but the episode certainly has not strengthened the claim of France to be regarded as having a special right in regard to the Congo. The United Kingdom, which with all its defects has nevertheless governed its African possessions with more success than any other Power, could on that ground prefer superior claims to consideration in the event of any proposal to alter Belgian sovereignty, and France has sufficient territory in Africa, especially with the losses on the Congo of 1911 made good, to dispense with any additions at the expense of an ally.

Apologists of Germany may still be found to maintain that it would be politic at least to concede a portion of the Congo territory to that Power as a means of securing the peace of Europe by satisfying her natural desire for colonial possessions. On any theory such a course could be justified only by the assumption that German native administration could be rated as high as that of the Belgian Congo, and on behalf of this plea has been invoked the doctrine that, while there have been cases of grave misgovernment in German territories in Africa, these have been punished by the German Government, and that her rule is at least equal to, if not superior to, that of Belgium. It is, however, impossible to accept this doctrine: there is abundant evidence that the policy of Germany, carried out with far more

1 It should, however, be noted that Lord Kimberley in a dispatch of August 14, 1894 (C. 9054, p. 17), denies that the right is binding on the Powers, without express assent, and suggests-as is true-that it is not quite compatible with the position of the territory. He insinuates doubt also as to the validity of the transmission of the right to the Congo State territory. 
ability and skill, has been precisely that of the State, the reduction of the natives into a condition in which they serve as effective instruments of production for European masters. The analogy between the methods adopted in the German invasion of Belgium and those of her colonial policy generally is too painfully obvious to be ignored by any candid judgement. A reign of terrorism is intended to be a prelude to the peaceful administration of a population which has learned to fear Germany and to obey, and which therefore may receive the favours appropriate to the submissive animal. The difference between the history of the German colonies and of the Congo State lies, not in the principles which were adopted, but in the methods of carrying them out, and, if the contrast is greatly to the advantage of German efficiency, it must be remembered that the King had only his own resources to look to, while Germany had the crushing power of a colossal State. To compare the German method of government with the Belgian under the régime introduced since the accession of King Albert is wholly unjust and misleading.

Moreover, the frank admission of the German ideal of creating a Central African Empire provided with a large native army, whose power has been so brilliantly shown by the Germans in their campaign in East Africa, and menacing the freedom of the seas by submarine bases safely protected by strong fortifications, ${ }^{1}$ would render any government which contemplated the expansion of German power in Africa liable to the most severe censure. It is, indeed, a matter of the utmost difficulty to decide whether on moral grounds the return to Germany of her former possessions could be justified, and no more difficult problem will come before the Peace Conference, if, as may be hoped, the outcome of the war leaves this matter to be settled by the calm judgement of the Powers other than Germany. Any solution of the problem must depend on the consideration of the wishes of the tribes in German territory, and the possibility of providing methods by which the restora-

1 See Chap. I; E. Cammaerts, National Rerierv, October 1916, pp. 205-11. 
tion of German rule will not become a source either of danger to the peace of the world or of oppression for the native. If, as may well be the case, territorial changes are made consequent on the war, the claim of Belgium to consideration in virtue of her occupation of Kigoma and Tabora will doubtless be borne in mind.

The war has altered in essentials the relation of Belgium to the United Kingdom, for before it broke out it was an obsession of Belgian statesmen that the integrity of the Congo was menaced by the British element in the Katanga, and the long-continued argument between the British and Belgian governments on the subject of the reforms in the Congo did not tend to diminish the friction. Unhappily the officials of the Katanga have on some occasions at least, as has been seen, interpreted their duty in the sense of aiming at discouraging the visits of any but Belgian subjects. From the abstract point of view it can indeed be argued that the Belgian claim to the Katanga is weak, that its flora and fauna are typically South African and distinguish it from the northern Congo, ${ }^{1}$ and that it was acquired by conquest at a moment when it seemed quite possible that it would become British. But, on the other hand, it is to the Katanga that the State must look for the wealth to develop the rest of the territory, and, while there is little prospect of successful Belgian colonization, it would be unfortunate if that possibility were not left to Belgium, a country without any obvious outlet for a population already very large in proportion to its area.

The United Kingdom has, however, a clear right to expect from Belgium, if it is desired, recognition of the right to create on territory placed for this purpose under British control a railway connecting the British territories to the north and south of the colony. ${ }^{2}$ The grant of this concession by Leopold II was prevented only by the intervention of Germany, and the reason against any such arrangement urged by Germany, that it would interpose

${ }^{1}$ Cd. 5649-129, p. 8.

${ }^{2}$ Cf. E. Lewin, United Empire, 1917, pp. 97-9. 
British influence between German territory and the Congo, is a most cogent ground for re-establishing the arrangement with such modifications as may be necessitated. Of these the most important is clearly the extension of the proposed lease of territory to permit of complete railway connexion, and not, as in 1894, merely of a connexion north of Tanganyika. To such an arrangement France should have no difficulty in agreeing, for the old quarrels with the State which motived her action in 1894 have disappeared, and the completion of the Cape to Cairo route has no terrors for France. The necessity of any such arrangement might of course be removed, if at the settlement it were possible to secure for the United Kingdom territory in German East Africa on which a line might be carried north from the Central Railway to Uganda, and if connexion were established between Broken Hill and Abercorn, the route being completed by the use of Tanganyika; but this alternative is not specially attractive. It must in any case be remembered that the problem of railway connexion between the Sudan and the northern Congo is still unsolved, so that the project of a Cape to Cairo line ${ }^{1}$ is yet attended with important difficulties. In return for such a lease of territory there is an obvious concession which the United Kingdom might make, the formal abandonment of the right to establish consular jurisdiction in the Congo which she enjoys under the treaty of 1884. The exercise of this right would, of course, be wholly inconsistent with the theory that Belgium is fit to be trusted with sovereign powers in the Congo, and its surrender by the United Kingdom might well be made a ground for its abandonment by Italy, and consequently by the other Powers entitled to it by virtue of the most favoured nation clauses in their treaties with the International Congo Association.

An alternative, however, to the retention of the status quo in Africa has been proposed, which is intended by its authors to solve the problem of the German possessions, without

${ }^{1}$ Cf. Major Christy's article on the Nile-Congo watershed, Geographical Joumal, September 1917, pp. 199-216. 
committing the crime of handing them over to Germany under circumstances which would permit of a repetition of the old régime. The doctrine received classical expression in the memorandum on war aims laid before the Labour Party by the Executive Committee of that body in August 1917. That manifesto contemplated the creation as an essential condition of the treaty of peace of a 'supernational authority or league of nations, which should not only be adhered to by the present belligerents, but which every other independent State in the world should be pressed to join'. It then proceeded to lay down the following doctrine for the future government of the territories of the Powers in Central Africa:

- With regard to the colonies of the several belligerents in tropical Africa, from sea to sea (north of the Zambesi river and south of the Sahara desert), the Conference disclaims all -sympathy with the imperialistic idea that these should form the booty of any nation, should be exploited for the profit of the capitalist, or should be used for the promotion of the militarist aims of governments. In view of the fact that it is impracticable here to leave the various peoples concerned to settle their own destinies, the Conference suggests that the interest of humanity would be best served by the full and frank abandonment by all belligerents of any dreams of an African empire; the transfer of all the present colonies of the European Powers in tropical Africa, together with the nominally independent republic of Liberia, to the proposed supernational authority or League of Nations herein suggested; and their administration by an impartial Commission under that authority with its own trained staff, as a single independent African state, on the principles of (1) the open door and equal freedom of enterprise to the traders of all nations; (2) protection of the natives against exploitation and oppression and the preservation of their tribal interests; (3) all revenue raised to be expended for the welfare and development of the African state itself; and (4) the permanent neutralization of this African state and its abstention from participation in international rivalries or any future war.'

To this interesting announcement a commentary was

${ }^{1}$ The Times, August 11, 1917. 
added by Mr. H. G. Wells on August $14,{ }^{1}$ when it was explained that the permanent peace of Europe was dependent on leaving the access to the raw materials of Africa free to all. German economic life, it was argued, would be practically destroyed by the shutting out of Germany from such access. 'Without humiliation or economic injury to Germany all that she needed could be secured by permitting her to share in the benefits of a pooled and neutralized Central Africa.' It is unnecessary to discuss the assumption that the war was then being prolonged by the efforts of the allies to shut out Germany from supplies of African products, for on August 28 the fundamental difficulties of the suggestion were exposed in a memorandum by the Independent Labour Party. ${ }^{2}$ It pointed out that the proposal would not. merely deprive Germany of all sovereignty in any part of Africa, but would take away from the Allied Powers, other than the United Kingdom, the sovereignty of most of their existing colonies, while leaving the British colonies in South Africa and South-West Africa still under the sovereignty of the United Kingdom, a principle which they thought contrary to the doctrine of no conquests as the outcome of the war. They added that they had 'grave doubts as to the practicability of any league of nations at present being able thoroughly to administer such an enormous area as the whole of Central Africa, a country without roads or railways'. They suggested, therefore, that for the time being 'it would be better if direct responsibility for the administration of divided areas were laid upon individual European states under the supervision of an International Commission charged with the oversight of the observance of the principles' enunciated in the memorandum presented to the Labour Party. Nothing, indeed, can be more Utopian than to imagine that the effort to govern such an area by a Commission would be productive of anything save the greatest amount of friction, leading

${ }_{1}$ Daily News and Leader; August 14, 1917 (circulated broadcast in pamphlet form).

${ }^{2}$ The Times, August 29, 1917. 
inevitably to renewed war. ${ }^{1}$ It was soon enough found by the Congo State that it was out of the question to operate effectively with a service which was not in the main of Belgian nationality, and the confusion which would result from an effort to create a truly international administration can scarcely be conceived. The proposal, in fact, argues a complete unfamiliarity with the extraordinarily complex nature of the government of native races. Happily, the error of the Labour Party was not perpetuated, doubtless in part at least as the result of the influence of M. Vandervelde, whose knowledge of the Congo revealed the fundamental errors of the proposal. The final view, therefore, of allied labour as adopted by the Interallied Labour and Socialist Conference which met in London in February 1918 was expressed as follows ${ }^{2}$ :

'With respect to these colonies, the Conference declares in favour of a system of control, established by international agreement under the League of Nations and maintained by its guarantee, which, whilst respecting national sovereignty, would be alike inspired by broad conceptions of economic freedom and concerned to safeguard the rights of the natives under the best conditions possible for them, and in particular (1) it would take account in each locality of the wishes of the people, expressed in the form which is possible to them. (2) The interests of the native tribes as regards the ownership of the soil would be maintained. (3) The whole of the revenues would be devoted to the wellbeing and development of the colonies themselves.'

'The establishment of a League of Nations is an ideal which has the imprimatur of the President of the United States, of the British Government, and in greater or less degree of the rest of the allied nations. ${ }^{3}$ It is perfectly obvious that the accomplishment of this ideal is an aim

${ }^{1}$ Cf. J. H. Harris's article on 'Tropical Colonies: International Government' in the Fortnightly Review, November, 1917. The unhappy condominium of the British and the French in the New Hebrides may be remembered. Cf. J. A. S. xvii. 278 sq.; Smuts, League of Nations, p. 18.

${ }^{2}$ The Times, February 25, 1918.

${ }^{3}$ See The League of Nations, by Viscount Grey, May 11, 1918, and cf. now the Peace Conference scheme, The Times, February 15, 1919. 
which can be perfected only in the course of years, possibly not for many decades, but there can be no doubt that the conception of establishing a new system of principles for the development of Central Africa is both timely and practicable. ${ }^{1}$ The Berlin Act was in its time an indication of a spirit of humanity and amity among the nations which unhappily was too alien to their natural disposition to have its full effect. Moreover, when it was drafted, it was impossible to foresee the many new forces which would arise, and the lapse of time alone would recommend its remodelling. It should not be forgotten that the framers of the Act themselves contemplated its revision in future, though they intended, as the language of several of the clauses ${ }^{2}$ which it contains proves beyond dispute, to establish by it principles which would survive the outbreak of war among the Powers signatory to the Act, and exempt its provisions from the normal fate of abrogation by act of war.

The first and most obvious defect which experience has revealed in the Act is the limited sphere of its operation. The narrowing of the limits in which free trade was to be established was due to the preoccupation of the Conference with the question of the Congo, and the failure of the United Kingdom to realize sufficiently keenly the necessity of protection for her trade on the west coast of Africa, while France for her part was resolved to make no concession on this head if it could be avoided. The loss to British interests caused by the French policy of rigid protection was in part but only temporarily remedied by the Anglo-French Convention of June 14, 1898, and the agreement of March 21, 1899, which secured, but for thirty years only, equal trade rights with the French in the French colonies of Dahomey and the Ivory Coast and in part of the region of Lake Chad, in return for the accord of reciprocal treatment to French subjects and protected persons in the whole of Nigeria and the Gold Coast. ${ }^{3}$ The advantages of these concessions may

${ }^{1}$ Cf. Mr. Cathcart Wason, J. A. S. xvii. 145-8; E. D. Morel, Africa and the Peace of Europe (1917).

${ }^{2}$ Articles X, XIII, XXV, XXVI, and XXXIII.

${ }^{3}$ C. 9334. 
be seen clearly enough by contrast with the disabilities suffered by British trade in Senegal, French Guinea, and the French Sudan, ${ }^{1}$ though even in these territories, it must be remembered, British trade has only had to struggle against a modified form of the French protective system. ${ }^{2}$ Yet more clear evidence is afforded by the case of French Equatorial Africa: the French Government in 1885 declined to accept the extension of the operation of the Berlin Act to the basin of the Ogoue, and in the result, while British trade has languished on the Gaboon, it has enjoyed comparative prosperity under the régime of the Berlin Act on the Middle Congo. ${ }^{3}$ Moreover, the present limits do not correspond with political boundaries: part of the Cameroons lie within, part without the free trade area: Angola, Northern Rhodesia, Portuguese East Africa, and Italian Somaliland are in no better case, while French and British Somaliland are entirely beyond the boundary, which on the other hand includes a little of the Sudan. It is a priori clear that the demand that the Zambezi and the Sahara should be the boundary limits is justified, and that it lies with any Power which desires exemption to establish a special case. The Sahara admittedly forms the natural basis of separation between the peoples akin to the Berbers and the negro races of the south: the Zambezi is doubtless a less distinct boundary line, but there is a real difference of peoples, climate, and land which sets the natural boundary for the advance of the Union at that river. ${ }^{4}$ German South-West Africa may, it is hoped, be regarded as permanently attached to the Union, for the policy of Germany in fomenting rebellion against the empire united the Imperial and the Union governments in the common interest of undoing the injury wrought by the sluggishness of the Cape Government in $1884 . .^{5}$

${ }^{1}$ Cd. 7048-52, p. 10.

${ }^{2}$ C. Humbert, L'Euvre française aux Colonies, p. 38.

${ }^{3}$ Cf. Cd. 7048-66, pp. 6, 7; Cd. 7620-104, pp. 9, 10.

${ }^{4}$ See J. A.'S. xvi. 173; xvii, 281-3.

${ }^{5}$ Fitzmaurice, Lord Granville, ii. 350 sq. Gen. Botha and Gen. Smuts 
Equally obvious is the necessity of securing some method by which the obligations of the Act may be made a reality, and converted into legal rules as opposed to moral principles devoid of any effective sanction. As has been seen, not only the State but the Belgian Government also maintained persistently the view that the British Government had no right whatever to intervene diplomatically on behalf of the natives, while the British Government, with equal energy and far more justice, contended ${ }^{1}$ that it had undoubtedly the right to demand that principles accepted in a treaty were conformed with. Nor can it be ignored that, even on commercial questions which directly affected the interest of British subjects, the Belgian Government adopted an attitude which can scarcely be regarded as other than cynical. It declined absolutely to accept arbitration unless the other Powers having possession in the conventional basin of the Congo ' had consented beforehand to intervene in the proceedings or to accept for their possessions the interpretation given by the award'. ${ }^{2}$ Such a reply was, of course, equivalent to an absolute refusal to arbitrate a case, doubtless recognized to be deplorably weak, for the difficulties of presenting to an arbitral tribunal an effective issue are sufficiently great even when only two Powers are concerned, and would become insuperable if the subject-matter were to be extended in the manner suggested. To meet these difficulties at least two alterations are demanded: it must be made clear that the whole of the clauses of the revised Act are of equal validity, and that the violation of any of them affords a ground for arbitration at the desire of any Power party to the Act, whether the interests of its own nationals are affected or not. Secondly, the resort to arbitration, at present voluntary, must be made compulsory, the right being accorded to those Powers which have possessions in the area to be represented before the tribunal if they

in this aspiration have the complete sympathy of all sections of British opinion; cf. Keith, The Times, January 1, 1917, p. 9; W. Long, ibid. February 1.

${ }^{1}$ Cd. 6606, p. 22.

${ }^{2}$ Cd. 4701, p. 9. 
consider that the award may in any way affect their interests. The award, however, would apply in express terms only to the case brought before it, for experience shows that it is quite impracticable to dispose of any issue in such manner as to exclude further points arising later on.

Great difficulties are presented by the question of freedom of trade. The language of the Act by its very width of enunciation gave to the maxim the appearance of vagueness while actually leaving open a loophole for evasion. The prohibition," which laid it down that no Power 'shall be allowed to grant a monopoly or favour of any kind in matters of trade', was positive enough, but, redacted at a period when the possibility of governmental exploitation does not appear to have been present to the minds of the delegates, it omitted entirely to deal with the case in which a government did not grant but exercised a monopoly. The King was astute to see the opportunity afforded, and it was quite possible to argue that the decrees of 1891-2 reserving the monopoly of the produce of the land were not violations of the Act, but merely measures destined to preserve the legitimate patrimony of the State, and Leopold II was able to collect a formidable array of juridical opinions in favour of this aspect of the case. The answer to this contention, indeed, could only be indirect, namely, as argued by the British Government, that the patrimony of the State had been extended to such an extent that the people of the State were without the means of carrying on trade of any kind with foreigners, and that the whole purpose of the Act which contemplated a régime of free trade with the natives was defeated. None the less, for a number of years the same unhappy doctrine was practised by France in the French Congo, where the concessionary régime was only put on a reasonable basis by the action of M. Merlin in 1910, at a time when the menace of Germany made it incumbent on France to set in order her colonial affairs. In both cases the loss to British trade was enormous: in the French Congo, from 1902 to 1911, 
the decline in exports to the United Kingdom was from 16 per cent. of the whole to $5 \cdot 3$ per cent., though the period saw an increase in the total of exports by 300 per cent. ${ }^{1}$ Nor should it be forgotten that the evil done by the concessionary régime remains after its modification or abolition : it is no easy matter to recover trade once diverted into other channels, as experience both in the Belgian Congo and in the French Congo proves.

It would, however, be wholly unwise to seek merely to make the prohibition wide enough to cover the exercise of a monopoly by the State. ${ }^{2}$ It cannot be argued that it is safe to forbid the State to grant a monopoly in matters such as the sale of alcohol, of tobacco, hemp, opium, arms, ammunition, \&c., and in fact the Brussels Act already assumed the exercise of control both as regards alcohol and the arms traffic. It is clear that monopolies, whether governmental or otherwise, may sometimes be justified in the interest either of the public security or health, and that it must be left to an arbitral tribunal to decide in any case of doubt.

Akin to the question of monopolies is the problem of concessions for such purposes as railway communication, which again is closely allied to the problem of the allocation of contracts for the needs of the State. In both cases the practice of the Belgian Congo has been national: the allotment of railway concessions has, since the proposal to give the line from Matadi to Leopoldville to a company largely British was negatived in deference to Belgian pressure, been entirely directed by the desire to serve Belgian interests, and the placing of contracts for governmental requirements has been restricted to Belgium while the railway companies and the Union minière were bound by their agreements with the Government to place their orders for goods in Belgium. It is a perfectly legitimate contention that the offer of equal facilities to tender in such cases is alone consistent with the régime of freedom

${ }^{1}$ Cd. 7048-66, p. 5.

${ }^{2}$ Cf. Lannoy, L'Organisation coloniale belge, pp. 177-80. 
of trade, and undoubtedly a system of open contracting for requirements of the Government and inviting tenders for concessions of railways, \&c., would be a legitimate ideal. It is, however, another question whether such an arrangement could practically be enforced: experience of any system of awarding contracts will suggest means by which the spirit of the rule could be evaded, without affording grounds for a successful appeal to arbitration, and, in the interest of the smooth working of international relations, it would probably be best to forgo this point. Such a decision might be defended more or less legitimately on the ground that contracts for governmental stores are too intimately connected with the conduct of administration to be properly made subject to rules which are meant to apply to the activities of trade, not to administration. The grant of such things as railway concessions falls within the same principle, though less clearly, on the ground of the great importance of such means of communication to a government of a tropical country, which renders it a matter of the highest interest that the Government should be able in times of political crisis to rest assured of the loyal support of the railway management.

The appropriation of the minerals of a tropical territory by the State, as was the case in the Congo, can hardly be regarded as other than legitimate when, as is usual, prior to the advent of the State authorities, mining has been for all practical purposes unknown. Here again a difficult problem presents itself as to the propriety of requiring that mineral rights should be offered on equal terms to all comers or the State be allowed to prefer its nationals. In this case also the paramount need of the State to retain in its own hands matters so important as minerals may be alleged in favour of the right to enact differentiation, but it is clear that this principle may be pressed too far, and that at most the right should be accorded of reserving for differential treatment those products which are essentially necessary for armaments. In point of fact, owing to the necessity of making use of British experience and capital, the Congo 
State was compelled from the first to admit British mining enterprise to a share in the Katanga area.

There is no essential difference between this case and that of the allocation of State lands. The State must be permitted to retain a discretion, but one only on grounds of public security in the widest sense, and the question of its action in any case must be left to arbitration.

The rigid prohibition of import duties, while no limit was imposed on export duties, by the Berlin Act was clearly doctrinaire, ${ }^{1}$ and was abrogated by the provision of the Brussels Act permitting the levy of duties to the amount of 10 per cent. ad valorem, alcohol and arms and ammunition being subjected to further duties by subsequent agreements. The limit of 10 per cent., however, is doubtless inelastic: in the French Congo the impossibility of making ends meet on the revenue available was one of the excuses for the imposition prematurely of direct taxation which raised serious native unrest, and it would seem necessary to introduce greater elasticity in the system. In tropical Africa it is more important to secure equality of duties for all trade than to limit the amount of duties, if that can only be done at the expense of hampering administration and forcing the adoption of means of taxation less easy to bear than customs duties.

Difficult as are the problems of preserving without injury to the State the maxim of commercial freedom, they are not comparable with those of securing the due regard for the welfare of the natives on which the Berlin Act laid so much stress. The valuelessness of the generalities of that Act is patent: beside the record of the Congo State must be set the disgraceful episodes of German rule, ${ }^{2}$ and

1 The attempt to see in it a fundamental principle of statesmanship is quite irrational.

2 The German treatment of its European prisoners, as well as of its native prisoners and subjects in the war, cannot be overlooked. Cf. Cd. 8689 ; J. H. Briggs, J. A. S. xvi. 196-9 ; F. R. Cana, ibid. xvii. 134, 135 ; E. Lewin and M. Montgomery-Campbell, Quarterly Review, April 1918, pp. 372-6 ; 'Africanus ', The Prussian Lash in Africa (1918); above, p. 12. 
the unhappy mismanagement of the French Congo, redeemed as it has been by the ability and energy of M. Merlin. Portuguese administration has often been unduly depreciated, but the position of the employees on San Thome and Principe has caused legitimate heart-searching to the British Government, and, though much has been done by Portugal to undo the evils of the régime, nevertheless it is idle to claim that she has completely succeeded. The essential difficulty of the situation lies in the fact of the slight distance which divides most of the natives of Central Africa from savagery: a strong administration is essential, but the powers which such an administration must entrust to its officers open the way to brutality and oppression. Britain, however, in this regard has an automatic safeguard, which has never existed in the Congo and which has not been deemed suitable by the Belgian Government ${ }^{1}$ : its officials are liable civilly and criminally for their administrative actions to the ordinary courts of the land, and are not protected by the maxim of continental law which demands that the executive power should not in its actions be hampered by subjection to judicial criticism.

The basis of all native interest is inevitably the land, and there has been seen the fatal results of a system which assumes, as was done by Leopold II, that political sovereignty conferred the right to appropriate the land for the benefit of others than the native owners. The native conception of land tenure undoubtedly assumes that the members of the tribe are entitled to the use of the tribal land, but that they have no power to alienate from the tribe the land which they cultivate. The intervention, therefore, of any government which abruptly determines that so much of the land shall be left to the natives, so much taken from them and made available for foreign settlement, is a distinct break with native use and wont and presents fundamental moral

1 The Commission which reported on the judicial system in 1913 to the Colonial Council would have given the Civil Courts power in all cases, but this view was rejected by the Government (see the report of the Council in Bulletin officiel, 1913, pp. 716 sq.). 
problems. South of the Zambezi in Southern Rhodesia these have now been definitely answered in the sense that a portion of the land has been allowed to remain in the hands of the natives, while a vast area has been appropriated for white settlement. ${ }^{1}$ North of the Zambezi, however, the excuse of settlement is normally lacking: with the exception of a portion of East Africa of no great importance, ${ }^{2}$ there is no area which is at all clearly fit for white settlement, and moral considerations would seem to make out a conclusive case for adopting the doctrine that the lands should be reserved for the future growth of the native races, and that alienations for any other purpose should be rare in the extreme. It was not until the Belgian Government had declared its readiness to promote the settlement of groups of natives on the domain lands that the United Kingdom saw its way clear to express recognition of the transfer of the State to Belgium.

In direct, if not necessary conscious, opposition to this conception of the duty of white peoples to natives is the view which has recently obtained formal and influential backing in the United Kingdom, that the government of a dependency is entitled to consider how much profit it may derive from developing it. Among the many interesting and quite absurd schemes ${ }^{3}$ of the Imperial Resources Development Commission is one which would secure the transfer to the British Government in order to liquidate the war debt of the profits of the palm products industry in West Africa. It is fair to say that the same body has proposed similar schemes which contemplate the turning to profit for the same excellent end of the resources of the self-governing

1 The British South Africa Company primarily, and the British Government secondarily, are responsible for the insufficiency of the areas reserved for native use. Cf. $\mathrm{Cd} .8674$.

${ }^{2}$ In East Africa the question of Indian settlement (G. H. Lepper, United Empire, 1915, pp. 350-3), recently urged by Sir T. Morison and the Aga Khan, presents further complications which it would here be irrelevant to consider.

${ }^{3}$ H.Wilson Fox, United Empire, 1918, p. 173 ; A. Bigland, ibid. p. 183. 
Dominions, but in their case the silence of the authorities appealed to sufficiently indicates the probability of any result being achieved by this propaganda. The appeal, however, when applied to the Crown colonies and protectorates, assumes a more dangerous form, for, while the Dominions are virtually independent States, these territories are dependent on the United Kingdom, and cannot effectively protect their interests against any wrong inflicted on them. The proposal would, of course, if carried into effect, run directly counter to the principles of the Berlin Act regarding the freedom of trade, for it would be the creation of a colossal monopoly of a kind which, on any theory, could not be described as legitimate. Curiously enough, however, the promoters of the scheme seem not to know that what they propose would lead to the direct revival of the evils of the State régime. The British Government learned with much satisfaction of the decision of the Belgian Government to abandon in toto the idea which it long held that it should develop certain definite areas as plantations on State account, because such a scheme involved dangers of a recurrence of the errors of the past. Under the proposal of the Commission, however, the West African Governments, now engaged in the duty of protecting the native from oppression and standing towards him in the attitude of a guardian and trustee, ${ }^{1}$ would be confronted with a great governmental organization bent on accumulating profits for the reduction of the national debt, to oppose which would be dangerous in the extreme. No nation can be sufficiently assured of its own virtue to feel secure that its standards of justice to native races would not suffer when it found that, by lowering them, it could remove a substantial part of a burden so colossal as that of the British national debt. The fact that so dangerous a scheme should have evoked any approval from representatives of Labour can "only be explained by

${ }^{1}$ Cf. the excellent criticisms of the scheme by Sir V. Buxton, United Empire, 1918, p. 185, and by R. E. Dennett, ibid. p. 186, and J. H. Harris, Colonial Dependencies: Possession or Trusteeship (Contemporary Review, February 1918, pp. 207-12). 
inexperience of the actual conditions of native administration in Africa.

There remains, however, an aspect of this question which does not admit of ready solution. The doctrine that the revenues of the territory are to be expended on it is sound and reasonable, and, in so far as it forbids the levying of tribute, uncontestably sound. But it is certainly not immoral to argue that the sums which a European government must expend in the early years of opening up a country may fairly be treated as advances to be repaid in due course, with or without interest, by the territory, and it is still more obvious that if a territory enjoys protection from external danger some contribution to the cost of naval and military defence generally is reasonable. The decision of the Imperial Government to permit of Nigeria assuming in all the burden of six million pounds of the war debt ${ }^{1}$ could be justified on either ground, for the grants in aid of the protectorate have been numerous, and the gain to Nigeria by its membership of the empire obvious. On the other hand, it is also obvious that care is necessary to secure that only reasonable amounts on these accounts are debited to any territory, based strictly on the gain to the territory and allowing for expenditure which, nominally on the territory, serves some other purpose. It would be easy enough to secure that no unfair advantage was taken of the territory. by adopting some simple criterion, such as wealth per head, in reckoning defence expenditure and by charging only actual advances with reasonable interest.

Other matters in which a definite policy can more or less safely be laid down are the questions of arms and ammunition, alcohol, the use of drugs, \&c. These matters should be regulated by common action from time to time, and the years which have elapsed since either the liquor ${ }^{2}$ or the arms question was adjusted render desirable a new revision of these matters. The experience of the Congo is clearly in

${ }^{1}$ Cd. 8434-7, p. 29 ; Cd. 8434-33, p. 34.

2 The period of ten years contemplated in the Brussels Act of 1906 expired in 1917. 
favour of the reduction of facilities for the use of alcohol, a matter in which the practice of the British colonies was largely improved under Mr. Harcourt's régime, ${ }^{1}$ and a determined effort to increase the restrictions on the supply of liquor is plainly overdue. Limitation of traffic in arms and ammunition will be more essential than ever after peace, and there is clearly room for readjustment of the arrangements which were agreed upon in 1908, but have since lapsed.

Experience in the Congo has shown the difficulty of adjusting the rights of missionary bodies of different faiths. In flat contradiction to the Berlin Act, Leopold II opposed difficulty after difficulty in the way of the Protestant Missions, refusing them year after year facilities for acquiring the necessary land for stations, despite his obligation to favour all such instrumentalities of furthering the regeneration of the natives. It would seem desirable, therefore, to enact that any favour given to one religious denomination by the State must be equally available to any other on the same conditions, a decision which would have the result of tending to eliminate competition between religious denominations for the favours of the State, a process disadvantageous alike to religion and to the State.

Further than this it is doubtless impossible safely to advance. The extraordinary difference of conditions which must exist in so vast an area as Central Africa would render useless or dangerous any effort to procure an Act which attempted in detail to determine native government or to deal with problems of the development of native.institutions, labour contracts, the introduction of individual property, or kindred topics. It might, however, be desirable to provide for the institution, as suggested by Sir Harry Johnston, ${ }^{2}$ of an International Council with advisory powers, on which all the nations interested in, as well as those having possessions in, Central Africa might be represented. Such a Commission with a small permanent staff could collect information on all the aspects of native problems and trade questions and

1 Keith, West Africa, pp. 210-14.

2 Journ. Soc. Comp. Leg. xviii. 39-41. 
discuss the issues at meetings held from time to time. ${ }^{1}$ The opinions formulated by the Council would then be communicated to the administrations, which would be required, not indeed to adopt them, but fo express their views upon them. There are, of course, objections, theoretical and practical, to such a Council, but in the ultimate issue these objections rest on the dislike of international interference or suggestion which is common to every nation in regard to the management of its colonies and protectorates, and the objections fall, therefore, to be judged on the general principle whether it is better to maintain the present isolation of nations, or to endeavour to create some form of unity.

The question of neutrality, which formed so important a feature in the opinions of some diplomats of the Berlin Act, offers many points of difficulty. The Act itself did not neutralize any portion of Africa : it merely imposed ${ }^{2}$ upon the signatory Powers, and any other Powers which accepted the Act, the duty of respecting the neutrality of any part of the area of free trade as delimited in the Act which was placed under the régime of neutrality by the Power exercising sovereign rights over it, so long as that Power respected the duties imposed upon it by neutrality. It also provided ${ }^{3}$ that in case of war between a signatory Power having possessions in the area and a non-signatory Power, the signatory Powers would endeavour to secure the neutralization of the portion of the area in possession of the one belligerent by mutual agreement between the two belligerents. The Act went further only in the case of the navigation of the Congo and the Niger ${ }^{4}$ : it provided that even in time of war the navigation of all neutral or belligerent nations should be free on these rivers and their affluents, and on roads, railways, and canals constructed to remedy imperfections of river transit, there being an exception made only in the case of the transport of goods for a belligerent, and in

1 The annual discussions of the Institut colonial international indicate the value of work conducted with fuller knowledge and responsibility.
${ }^{2}$ Art. X.
${ }^{3}$ Art. XI.
${ }^{4}$ Arts. XXV and XXXIII. 
virtue of the law of nations regarded as contraband of war. Before the war the only territory which was under the régime of neutrality was the Belgian Congo, and, as has been seen, Germany violated that neutrality on August 22, 1914, thereby forcing Belgium to permit the extension of the war to Africa. Neither France nor the United Kingdom found it possible to accept the suggestion of Belgium to place their territories in the Congo basin under the same régime, and Germany made a proposal to this effect only when she became convinced that this was the one means of saving her territories from capture.

It has recently been argued with much energy by Mr. E. D. Morel, ${ }^{2}$ and at one time laid down by the Executive Committee of the Labour Party, that the neutralization of the whole of Central Africa is essential. The defect of the Berlin Act, it is urged, is the fact that it made neutralization merely optional, and that in any case it extended to so limited an area as to render neutrality almost impossible in view of the absurdities which acceptance of it would have produced. But it is impossible to dispose of the question without consideration of the wider question whether neutralization can any longer be regarded as a useful international remedy. Is it not the case that the neutrality of Belgium proved a snare and a delusion ${ }^{3}$ by lulling the Belgian people into a false security which left them without an effective means of resisting the attack of Germany on their neutral position? Belgium had had warnings enough from the more far-seeing of its statesmen -including, it is only just to remember, Leopold II-of the danger of German aggression, but the measure of protection which an effective army of 350,000 men would have secured to her was only under contemplation when the

1 On August 15 ; see Jules Renkin et la conquête africaine, p. 20.

2 Africa and the Peace of Europe, pp. 63-78.

${ }^{3}$ Cf. the danger to Belgium from 1866 onwards, Benedetti, Ma mission en Prusse, pp. 147-201 ; Fitzmaurice, Lord Granville, ii. 39 sq.; The Times History of the War, i. 99 sq.; Beyens, Revue des Deux Mondes, July $1,1918$. 
invasion actually came and found her reduced to appealing for help to the Powers which had guaranteed her position. It may be regarded as more than doubtful whether Belgium would be wise in accepting again the position assigned to her by the treaties of 1831 and 1839, in the face of so marked a warning of the truth of the German belief in the doctrine that international law is to be respected only in so far as it subserves national ends for the time being. Nor would mere neutralization in itself prevent the danger on which General Smuts, from painful personal experience, has laid so much stress : the war in German East Africa showed that properly armed and led African troops were formidable adversaries, and even if neutralization were pronounced it would be open to any Power having African possessions to train in them large bodies of men which it could use offensively, if it thought well to disregard neutralization. Neutralization, in fact, is a danger to honest, and a boon to dishonest, Powers: despite all the play made by Germany with the fact that in 1906 and 1912 British military circles had been aware of the danger to Belgium of an attack from Germany, it can hardly be doubted that British governments could not face - and certainly did not encourage the public to face-the belief that such an attack was not merely possible but probable, or they would have made military preparations on a very different scale. France also, as the event proved, was far from having organized herself for an effective defence of Belgium immediately after the outbreak of war. Great, however, as are the objections to neutralization in any case, they become quite insuperable when it comes to be a question of merely neutralizing a part of Africa: had such an arrangement as is proposed been in force in 1914 it would have meant that Germany could have massacred in Belgium at pleasure, assured that her territories in the Cameroons, Togoland, and German East Africa, whence she draws the raw material which is so important to her in the view of her apologists, were absolutely safe, and that she need risk no punishment in territory beyond Europe in the case of defeat. 
The true policy to be adopted in the matter must, it would seem, ignore any effort to mitigate the effects of war when it breaks out, since experience shows that in the struggles of great nations international conventions bind only the more honest Powers, to their grave detriment, and to concentrate energy on the creation of circumstances which will effectively deter Powers from going to war. The means of accomplishing this are scanty and the path is difficult, but the fact that no immediate possibility exists of creating an effective League of Nations is not an argument for having recourse to obsolete methods of proved inefficiency, such as neutralization. A more practicable, though very difficult, principle which might at once be laid down, is the imposition of definite limits on the number of native troops which may be maintained or trained by Powers possessing African dependencies : to be effective such a measure would require arrangements for close supervision and inspection in order to counter the various methods of evasion which history has exhibited or ingenuity can improvise, and the question is complicated by the raising of strong native forces in the French possessions in West and Equatorial Africa, and by the excellent services which these troops have rendered the cause of civilization. But with the establishment of peace France would very possibly be willing to accept a limitation if secured that it would be made effective in the territories-if any-which a Peace Conference allots to Germany in Africa.

With the provisions for facultative neutralization there should disappear from the Act the fanciful efforts to open the Congo and the Niger to the commerce of belligerents in time of war: apparently under the terms of the Act it should have been legitimate for German vessels to ply on the Congo and on the Niger exempt from fear of capture, while France and Belgium and the United Kingdom were at war against German aggression, a claim which no Power should possibly accept for a moment. With these articles should go also the elaborate code ${ }^{1}$ for the regulation of the ${ }^{1}$ Arts. XVII-XXIII and VIII. 
navigation of the Congo by a Permanent Commission, which has never been established and is plainly unnecessary and undesirable, while the sixth chapter ${ }^{1}$ of the Act, which deals with the formalities requisite on the taking possession of an unoccupied part of the African coast, has played whatever part belonged to it, and has ceased to have any importance.

In the drafting of the Berlin Act, as in the formation of the Congo State, no small part was played by the United States, though the ratification of that country was refused to the Act as finally passed. The motives of the United States in this abstention can be gathered clearly enough from the Resolution with which the. Senate accompanied their acceptance in $1892^{2}$ of the Brussels Act of 1890. It was then resolved 'that the United States of America, having neither possessions nor protectorates $^{3}$ in Africa, hereby disclaims any intention in ratifying this treaty to indicate any interest whatsoever in the possessions or protectorates established or claimed on that continent by the other Powers, or any approval of the wisdom, expediency, or lawfulness thereof, and does not join in any expressions in the said General Act which might be construed as such a declaration or acknowledgement'. Less than a quarter of a century has availed so to alter the position of the United States that in any discussion of the future of Africa her voice must have all but decisive weight, as representing the only great Power which is at once in the fullest sense disinterested and fully cognizant of the great issues which must inevitably turn on the wisdom of the final settlement of the affairs of Africa.

None of the suggestions for the recasting of the Berlin Act made above present insoluble difficulties, but undoubtedly they assume a régime in which appeals to arbitration might be numerous and even annoying. It must,

1 Arts. XXXIV and XXXV.

${ }^{2}$ C. 6557 , p. 106.

${ }^{3}$ Liberia, however, has always been more or less clearly an American protectorate ; see Hertslet, Map of Africa by Treaty, ii. 1130, 1131. 
however, be recognized that this is an essential condition of the establishment of a reign of international law, and that nations which approve the ideal of a League of Nations must accept as part of the advantages of the scheme the introduction of frequent references to arbitral tribunals which will pass judgement on the administrative acts and the legislation of states. In the first instance, at least, it will probably not be desirable to give the arbitration tribunal which should be constituted to deal with complaints of infraction of the revised code for Central Africa direct power to hear appeals from national courts, as it was proposed to give to the International Prize Court which was to have administered the rules of the Declaration of London. Any such course would greatly increase possibilities of friction and would interfere unduly with the national sovereignty which must lie at the basis of the scheme. But it would be an obligation of honour on the contracting Powers to give effect readily and fully to the principles defined in any arbitration, whether they were in accord with their views or not, and the success of the scheme would rest on their readiness cheerfully to face this obligation in lieu of leaving open the possibility of recourse to the barbarism and havoc of war.

It must be admitted at the same time that, while the scheme is practicable, its adoption would mean definite sacrifices by all the Powers concerned. On France it would entail the definite decision to abandon her policy of reserving to her own citizens as far as practicable the commerce of her colonies. The attraction of such a policy is obvious, and it is difficult to censure France for acting on it at a time when the principle of preference to the oversea possessions of the Crown has received the approval of a British Government. Nevertheless it may be hoped that both France and the United Kingdom may rise superior to the temptation to adopt so narrow a view in their African lands, for the maintenance of trade barriers is, and always will be, productive of bitterness of feeling and contains the seeds of future wars. In this case, ex hypothesi-since if 
the views of General Smuts ${ }^{1}$ and Mr. Balfour ${ }^{2}$ prevail, Germany will not possess any colonial territory unless the Powers are satisfied of her reformation-there will be lacking the justification of preferential terms arising from the necessity of self-preservation, which is accepted by the Declaration of Paris of 1916, and France will act wisely if she accepts for all her African territories the régime of freedom of trade which has been enacted for Morocco. The United Kingdom also will be no loser if she is debarred from experiments in the exploitation of her tropical dependencies in her own interest. Nor will Italy suffer in the slightest from the adoption of such a régime as is proposed.

The position of Portugal is admittedly peculiar and difficult: the weakness of Portugal and her poverty have rendered it natural to assume that her territories must sooner or later be partitioned between the two Powers which have obviously the best territorial claims to fall heirs to her territories in Africa, the United Kingdom and Germany, and Prince Lichnowsky ${ }^{3}$ has intimated the details of the agreement which was all but concluded in 1913-14 in substitution for the arrangements made in 1898-9 by Lord Salisbury's government. The disappearance of these understandings, the later never completed, as the result of war leaves the position of Portugal in Africa more stable than before, but it is idle to suppose that the Powers will indefinitely acquiesce in any régime which does not open the territory of Portugal on the east and west coasts alike to freedom of trade. A system such as that in force in Angola, under which land could not be acquired by other than Portuguese subjects, and exports which paid 3 per cent. if shipped in Portuguese bottoms were mulcted in 15 per cent. if carried in foreign vessels or to foreign countries in Portuguese vessels, is not seriously to be defended except by the most advanced holders of protective theories, especially when the result of the policy is stagnation pure and

1 The Times, September 13, 1918.

${ }^{2}$ Cf. Lord R. Cecil in The Times, August 24, 1918.

s My Mission to London, pp. 14-19. 
simple. Portugal also must reform in essential aspects her treatment of the natives who go to labour on San Thomé and Principe, if she is to conform to the standard of treatment worthy of a humane Power. Happily the adoption of a policy of free trade would bring to Portugal the capital which she essentially needs as the condition of developing her territories. She would be able then to reorganize and make effective her administration, and would have no temptation to overlook abuses such as those of the workers on the cocoa plantations because of the source of wealth which these undertakings bring to the State. ${ }^{1}$

1 Since this work was written the Peace Conference has decided upon the application of the system of mandate to the territorial possessions of Germany outside Europe, but the fundamental question of the revision and extension of the Berlin Act remains untouched, and its solution will be one of the most pressing duties of any League of Nations. At the Conference France and the United Kingdom are pledged by declarations of April 29, 1916, to secure the territorial integrity of the Congo and a special indemnity to cover the damage suffered during the war, and the United Kingdom, in lending 90,000,000 francs to the Colony, did so unconditionally, and without claiming any political or economic advantages (Belgian declaration, January 21, 1917 ; Belgique et Congo, pp. 121, 122). 


\section{APPENDIX}

\section{GENERAL ACT OF THE CONFERENCE OF BERLIN, Signed February 26, 1885}

Chapter I.-Declaration relative to Freedom of Trade in the Basin of the Congo, its Mouths and circumjacent Regions, with other Provisions connected therewith.

\section{Article 1.}

The trade of all nations shall enjoy complete freedom-

1. In all the regions forming the basin of the Congo and its outlets. This basin is bounded by the watersheds (or mountain ridges) of the adjacent basins, namely, in particular, those of the Niari, the Ogowé, the Schari, and the Nile, on the north; by the eastern watershed line of the affluents of Lake Tanganyika on the east; and by the watersheds of the basins of the Zambesi and the Logé on the south. It therefore comprises all the regions watered by the Congo and its affluents, including Lake Tangan- . yika, with its eastern tributaries.

2. In the maritime zone extending along the Atlantic Ocean from the parallel situated in $2^{\circ} 30^{\prime}$ of south latitude to the mouth of the Logé.

The northern boundary will follow the parallel situated in $2^{\circ} 30^{\prime}$ from the coast to the point where it meets the geographical basin of the Congo, avoiding the basin of the Ogowé, to which the provisions of the present Act do not apply.

The southern boundary will follow the course of the Logé to its source, and thence pass eastwards till it joins the geographical basin of the Congo.

3. In the zone stretching eastwards from the Congo Basin as above defined, to the Indian Ocean from 5 degrees of north latitude to the mouth of the Zambesi in the south, from which point the line of demarcation will ascend the Zambesi to 5 miles above its confluence with the Shiré, and then follow the watershed 
between the affluents of Lake Nyassa and those of the Zambesi, till at last it reaches the watershed between the waters of the Zambesi and the Congo.

It is expressly recognized that in extending the principle of free trade to this eastern zone, the Conference Powers only undertake engagements for themselves, and that in the territories belonging to an independent Sovereign State this principle shall only be applicable in so far as it is approved by such State. But the Powers agree to use their good offices with the Governments established on the African shore of the Indian Ocean for the purpose of obtaining such approval, and in any case of securing the most favourable conditions to the transit (traffic) of all nations.

\section{Article 2.}

All flags, without distinction of nationality, shall have free access to the whole of the coast-line of the territories above. enumerated, to the rivers there running into the sea, to all the waters of the Congo and its affluents, including the lakes, and to all the ports situate on the banks of these waters, as well as to all canals which may in future be constructed with intent to unite the watercourses or lakes within the entire area of the territories described in Article 1. Those trading under such flags may engage in all sorts of transport, and carry on the coasting trade by sea and river, as well as boat traffic, on the same footing as if they were subjects.

\section{Article 3.}

Wares, of whatever origin, imported into these regions, under whatsoever flag, by sea or river, or overland, shall be subject to no other taxes than such as may be levied as fair compensation for expenditure in the interests of trade, and which for this reason must be equally borne by the subjects themselves and by foreigners of all nationalities. All differential dues on vessels, as well as on merchandize, are forbidden.

\section{Article 4.}

Merchandize imported into these regions shall remain free from import and transit dues.

The Powers reserve to themselves to determine after the lapse 
of twenty years. whether this freedom of import shall be retainèd or not.

\section{Article 5.}

No Power which exercises or shall exercise sovereign rights in the above-mentioned regions shall be allowed to grant therein a monopoly or favour of any kind in matters of trade.

Foreigners, without distinction, shall enjoy protection of their persons and property, as well as the right of acquiring and transferring movable and immovable possessions; and national rights and treatment in the exercise of their professions.

Article 6.-Provisions relative to Protection of the Natives, of Missionaries and Travellers, as well as relative to Religious Liberty.

All the Powers exercising sovereign rights or influence in the aforesaid territories bind themselves to watch over the preservation of the native tribes, and to care for the improvement of the conditions of their moral and material well-being, and to help in suppressing slavery, and especially the Slave Trade. They shall, without distinction of creed or nation, protect and favour all religious, scientific, or charitable institutions, and undertakings created and organized for the above ends, or which aim at instructing the natives and bringing home to them the blessings of civilization.

Christian missionaries, scientists, and explorers, with their followers, property, and collections, shall likewise be the objects of especial protection.

Freedom of conscience and religious toleration are expressly guaranteed to the natives, no less than to subjects and to foreigners. The free and public exercise of all forms of Divine worship, and the right to build edifices for religious purposes, and to organize religious Missions belonging to all creeds, shall not be limited or fettered in any way whatsoever.

\section{Article 7.-Postal Régime.}

The Convention of the Universal Postal Union, as revised at. Paris the 1st June, 1878, shall be applied to the Conventional basin of the Congo.

The Powers who therein do or shall exercise rights of sove- 
reignty or Protectorate engage, as soon as circumstances permit them, to take the measures necessary for the carrying out of the preceding provision.

\section{Artrcle 8.-Right of Surveillance vested in the International Navigation Commission of the Congo.}

In all parts of the territory had in view by the present Declara. tion, where no Power shall exercise rights of sovereignty or Protectorate, the International Navigation Commission of the Congo, instituted in virtue of Article 17, shall be charged with supervising the application of the principles proclaimed and perpetuated ('consacrés ') by this Declaration.

In all cases of difference arising relative to the application of the principles established by the present Declaration, the Governments concerned may agree to appeal to the good offices of the International Commission, by submitting to it an examination of the facts which shall have occasioned these differences.

Chapter II.-Declaration relative to the Slave Trade.

\section{Artiche 9.}

Seeing that trading in slaves is forbidden in conformity with the principles of international law as recognized by the Signatory Powers, and seeing also that the operations, which, by sea or land, furnish slaves to trade, ought likewise to be regarded as forbidden, the Powers which do or shall exercise sovereign rights or influence in the territories forming the Conventional basin of the Congo, declare that these territories may not serve as a market or means of transit for the trade in slaves, of whatever race they may be. Each of the Powers binds itself to employ all the means at its disposal for putting an end to this trade and for punishing those who engage in it.

Chapter III.-Declaration relative to the Neutrality of the Territories comprised in the Conventional Basin of the Congo.

\section{Article 10.}

In order to give a new guarantee of security to trade and industry, and to encourage, by the maintenance of peace, the development of civilization in the countries mentioned in Article 1, and placed under the free trade system, the High Signatory 
Parties to the present Act, and those who shall hereafter adopt it, bind themselves to respect the neutrality of the territories, or portions of territories, belonging to the said countries, comprising therein the territorial waters, so long as the Powers which exercise or shall exercise the rights of sovereignty or Protectorate over those territories, using their option of proclaiming themselves neutral, shall fulfil the duties which neutrality requires.

\section{Article 11.}

In case a Power exercising rights of sovereignty or Protectorate in the countries mentioned in Article 1, and placed under the free trade system, shall be involved in a war, then the High Signatory Parties to the present Act, and those who shall hereafter adopt it, bind themselves to lend their good offices in order that the territories belonging to this Power and comprised in the Conventional free trade zone shall, by the common consent of this Power and of the other belligerent or belligerents, be placed during the war under the rule of neutrality, and considered as belonging to a non-belligerent State, the belligerents thenceforth abstaining from extending hostilities to the territories thus neutralized, and from using them as a base for warlike operations.

\section{Article 12.}

In case a serious disagreement originating on the subject of, or in the limits of, the territories mentioned in Article 1 and placed under the free trade system, shall arise between any Signatory Powers of the present Act, or the Powers which may become parties to it, these Powers bind themselves, before appealing to arms, to have recourse to the mediation of one or more of the friendly Powers.

In a similar case the same Powers reserve to themselves the option of having recourse to arbitration.

\section{Chapter IV.-Act of Navigation for the Congo.}

Article 13.

The navigation of the Congo, without excepting any of its branches or outlets, is, and shall remain, free for the merchantships of all nations equally, whether carrying cargo or ballast, for the transport of goods or passengers. It shall be regulated 
by the provisions of this Act of Navigation, and by the Rules to be made in pursuance thereof.

In the exercise of this navigation the subjects and flags of all nations shall in all respects be treated on a footing of perfect equality, not only for the direct navigation from the open sea to the inland ports of the Congo and vice versa, but also for the great and small coasting trade, and for boat traffic on the course of the river.

Consequently, on all the course and mouths of the Congo there will be no distinction made between the subjects of Riverain States and those of non-Riverain States, and no exclusive privilege of navigation will be conceded to Companies, Corporations, or private persons whatsoever.

These provisions are recognized by the Signatory Powers as becoming henceforth a part of international law.

\section{Article 14.}

The navigation of the Congo shall not be subject to any restriction or obligation which is not expressly stipulated by the present Act. It shall not be exposed to any landing dues, to any station or depôt tax, or to any charge for breaking bulk, or for compulsory entry into port.

In all the extent of the Congo the ships and goods in process of transit on the river shall be submitted to no transit dues, whatever their starting-place or destination.

There shall be levied no maritime or river toll based on the mere fact of navigation, nor any tax on goods aboard of ships. There shall only be levied taxes or duties having the character of an equivalent for services rendered to navigation itself, to wit:-

1. Harbour dues on certain local establishments, such as wharves, warehouses, \&c., if actually used.

The Tariff of such dues shall be framed according to the cost of constructing and maintaining the said local establishments; and it will be applied without regard to whence vessels come or what they are loaded with.

2. Pilot dues for those stretches of the river where it may be necessary to establish properly-qualified pilots.

The Tariff of these dues shall be fixed and calculated in proportion to the service rendered. 
3. Charges raised to cover technical and administrative expenses incurred in the general interest of navigation, including lighthouse, beacon, and buoy duties.

The last-mentioned dues shall be based on the tonnage of vessels as shown by the ship's papers, and in accordance with the Rules adopted on the Lower Danube.

The Tariffs by which the various dues and taxes enumerated in the three preceding paragraphs shall be levied, shall not involve any differential treatment, and shall be officially published at each port.

The Powers reserve to themselves to consider, after the lapse of five years, whether it may be necessary to revise, by common accord, the above-mentioned Tariffs.

\section{Article 15.}

The affluents of the Congo shall in all respects be subject to the same Rules as the river of which they are tributaries.

And the same Rules shall apply. to the streams and rivers as well as the lakes and canals in the territories defined in paragraphs 2 and 3 of Article 1.

At the same time the powers of the International Commission of the Congo will not extend to the said rivers, streams, lakes, and canals, unless with the assent of the States under whose sovereignty they are placed. It is well understood, also, that with regard to the territories mentioned in paragraph 3 of Article 1, the consent of the Sovereign States owning these territories is reserved.

\section{Article 16.}

The roads, railways, or lateral canals which may be constructed with the special object of obviating the innavigability or correcting the imperfection of the river route on certain sections of the course of the Congo, its affluents, and other water-ways placed under a similar system, as laid down in Article 15, shall be considered in their quality of means of communication as dependencies of this river, and as equally open to the traffic of all nations.

And, as on the river itself, so there shall be collected on these roads, railways, and canals only tolls calculated on the cost of construction, maintenance, and management, and on the profits due to the promoters. 
As regards the Tariff of these tolls, strangers and the natives of the respective territories shall be treated on a footing of perfect equality.

\section{Article 17.}

There is instituted an International Commission, charged with the execution of the provisions of the present Act of Navigation.

The Signatory Powers of this Act, as well as those who may subsequently adhere to it, may always be represented on the said Commission, each by one Delegate. But no Delegate shall have more than one vote at his disposal, even in the case of his representing several Governments.

This Delegate will be directly paid by his Government. As for the various agents and employés of the International Commission, their remuneration shall be charged to the amount of the dues collected in conformity with paragraphs 2 and 3 of Article 14.

The particulars of the said remuneration, as well as the number, grade, and powers of the agents and employés, shall be entered in the returns to be sent yearly to the Governments represented on the International Commission.

\section{Article 18.}

The members of the International Commission, as well as its appointed agents, are invested with the privilege of inviolability in the exercise of their functions. The same guarantee shall apply to the offices and archives of the Commission.

\section{Article 19.}

The International Commission for the Navigation of the Congo shall be constituted as soon as five of the Signatory Powers of the present General Act shall have appointed their Delegates. And pending the constitution of the Commission the nomination of these Delegates shall be notified to the Imperial Government of Germany, which will see to it that the necessary steps are taken to summon the meeting of the Commission.

The Commission will at once draw up navigation, river police, pilot, and quarantine Rules.

These Rules, as well as the Tariffs to be framed by the Commission, shall, before coming into force, be submitted for approval 
to the Powers represented on the Commission. The Powers interested will have to communicate their views with as little delay as possible.

Any infringements of these Rules will be checked by the agents of the International Commission wherever it exercises direct authority, and elsewhere by the Riverain Power.

In the case of an abuse of power, or of an act of injustice, on the part of any agent or employé of the International Commission, the individual who considers himself to be aggrieved in his person or rights may apply to the Consular Agent of his country. The latter will examine his complaint, and if he finds it prima facie reasonable, he will then be entitled to bring it before the Commission. At his instance then, the Commission, represented by at least three of its members, shall, in conjunction with him, inquire into the conduct of its agent or employé. Should the Consular Agent look upon the decision of the Commission as raising questions of law ('objections de droit'), he will report on the subject to his Government, which may then have recourse to the Powers represented on the Commission, and invite them to agree as to the instructions to be given to the Commission.

Article 20.

The International Commission of the Congo, charged in terms of Article 17 with the execution of the present Act of Navigation, shall in particular have power-

1. To decide what works are necessary to assure the navigability of the Congo in accordance with the needs of.international trade.

On those sections of the river where no Power exercises sovereign rights, the International Commission will itself take the necessary measures for assuring the navigability of the river.

On those sections of the river held by a Sovereign Power the International Commission will concert its action (' s'entendra') with the riparian authorities.

2. To fix the pilot tariff and that of the general navigation dues as provided for by paragraphs 2 and 3 of Article 14.

The Tariffs mentioned in the first paragraph of Article 14 shall be framed by the territorial authorities within the limits prescribed in the said Article.

The levying of the various dues shall be seen to by the inter- 
national or territorial authorities on whose behalf they are established.

3. To administer the revenue arising from the application of the preceding paragraph (2).

4. To superintend the quarantine establishment created in virtue of Article 24.

5. To appoint officials for the general service of navigation, and also its own proper employés.

It will be for the territorial authorities to appoint SubInspectors on sections of the river occupied by a Power, and for the International Commission to do so on the other sections.

The Riverain Power will notify to the International Commission the appointment of Sub-Inspectors, and this Power will undertake the payment of their salaries.

In the exercise of its functions, as above defined and limited, the International Commission will be independent of the territorial authorities.

\section{Article 21.}

In the accomplishment of its task the International Commission may, if need be, have recourse to the war-vessels of the Signatory Powers of this Act, and of those who may in future accede to it, under reserve, however, of the instructions which may be given to the Commanders of these vessels by their respective Governments.

\section{Article 22.}

The war-vessels of the Signatory Powers of this Act that may enter the Congo are exempt from payment of the navigation dues provided for in paragraph 3 of Article 14 ; but unless their intervention has been called for by the International Commission or its agents, in terms of the preceding Article, they shall be liable to the payment of the pilot or harbour dues which may eventually be established.

\section{Article 23.}

With the view of providing for the technical and administrative expenses which it may incur, the International Commission created by Article 17 may, in its own name, negotiate loans to be exclusively guaranteed by the revenues raised by the said Commission. 
The decisions of the Commission dealing with the conclusion of a loan must be come to by a majority of two-thirds. It is understood that the Governments represented on the Commission shall not in any case be held as assuming any guarantee, or as contracting any engagement or joint liability ('solidarité ') with respect to the said loans, unless under special Conventions concluded by them to this effect.

The revenue yielded by the dues specified in paragraph 3 of Article 14 shall bear, as a first charge, the payment of the interest and sinking fund of the said loans, according to agreement with the lenders.

\section{Article 24.}

At the mouth of the Congo there shall be founded, either on the initiative of the Riverain Powers, or by the intervention of the International Commission, a quarantine establishment for the control of vessels passing out of as well as into the river.

Later on the Powers will decide whether and on what conditions a sanitary control shall be exercised over vessels engaged in the navigation of the river itself.

\section{Article 25.}

The provisions of the present Act of Navigation shall remain in force in time of war. Consequently all nations, whether neutral or belligerent, shall be always free, for the purposes of trade, to navigate the Congo, its branches, affluents, and mouths, as well as the territorial waters fronting the embouchure of the river.

Traffic will similarly remain free, despite a state of war, on the roads, railways, lakes, and canals mentioned in Articles 15 and 16.

There will be no exception to this principle, except in so far as concerns the transport of articles intended for a belligerent, and in virtue of the law of nations regarded as contraband of war.

All the works and establishments created in pursuance of the present Act, especially the tax-collecting offices and their treasuries, as well as the permanent service staff of these establishments, shall enjoy the benefits of neutrality ("placés sous le régime de la neutralité '), and shall, therefore, be respected and protected by belligerents. 
Chapter V.-Act of Navigation for the Niger.

Article 26.

The navigation of the Niger, without excepting any of its branches and outlets, is and shall remain entirely free for the merchant-ships of all nations equally, whether with cargo or ballast, for the transportation of goods and passengers. It shall be regulated by the provisions of this Act of Navigation, and by the rules to be made in pursuance of this Act.

In the exercise of this navigation the subjects and flags of all nations shall be treated, in all circumstances, on a footing of perfect equality, not only for the direct navigation from the open sea to the inland ports of the Niger, and vice versa, but for the great and small coasting trade, and for boat trade on the course of the river.

- Consequently, on all the course and mouths of the Niger there will be no distinction made between the subjects of the Riverain States and those of non-Riverain States; and no exclusive privilege of navigation will be conceded to Companies, Corporations, or private persons.

These provisions are recognized by the Signatory Powers as forming henceforth a part of international law.

\section{Article 27.}

The navigation of the Niger shall not be subject to any restriction or obligation based merely on the fact of navigation.

It shall not be exposed to any obligation in regard to landingstation or depôt, or for breaking bulk, or for compulsory entry into port.

In all the extent of the Niger the ships and goods in process of transit on the river shall be submitted to no transit dues, whatever their starting-place or destination.

No maritime or river toll shall be levied based on the sole fact of navigation, nor any tax on goods on board of ships. There shall only be collected taxes or duties which shall be an equivalent for services rendered to navigation itself. The Tariff of these taxes or duties shall not warrant any differential treatment.

\section{Article 28.}

The affluents of the Niger shall be in all respects subject to the same rules as the river of which they are tributaries. 
Article 29.

The roads, railways, or lateral canals which may be constructed with the special object of obviating the innavigability or correcting the imperfections of the river route on certain sections of the course of the Niger, its affluents, branches, and outlets, shall be considered, in their quality of means of communication, as dependencies of this river, and as equally open to the traffic of all nations.

And, as on the river itself, so there shall be collected on these roads, railways, and canals only tolls calculated on the cost of construction, maintenance, and management, and on the profits due to the promoters.

As regards the Tariff of these tolls, strangers and the natives of the respective territories shall be treated on a footing of perfect equality.

\section{Article 30.}

Great Britain undertakes to apply the principles of freedom of navigation enunciated in Articles 26, 27, 28, and 29 on so much of the waters of the Niger, its affluents, branches, and outlets, as are or may be under her sovereignty or protection.

The rules which she may establish for the safety and control of navigation shall be drawn up in a way to facilitate, as far as possible, the circulation of merchant-ships.

It is understood that nothing in these obligations shall be interpreted as hindering Great Britain from making any rules of navigation whatever which shall not be contrary to the spirit of these engagements.

Great Britain undertakes to protect foreign merchants and all the trading nationalities on all those portions of the Niger which are or may be under her sovereignty or protection as if they were her own subjects, provided always that such merchants conform to the rules which are or shall be made in virtue of the foregoing.

\section{Article 31.}

France accepts, under the same reservations, and in identical terms, the obligations undertaken in the preceding Articles in respect of so much of the waters of the Niger, its affluents, branches, and outlets, as are or may be under her sovereignty or protection. 
Article 32.

f Each of the other Signatory Powers binds itself in the same way in case it should ever exercise in the future rights of sovereignty or protection over any portion of the waters of the Niger, its affluents, branches, or outlets.

\section{Article 33.}

The arrangements of the present Act of Navigation will remain in force in time of war. Consequently, the navigation of all neutral or belligerent nations will be in all time free for the usages of commerce on the Niger, its branches, its affluents, its mouths, and outlets, as well as on the territorial waters opposite the mouths and outlets of that river.

The traffic will remain equally free in spite of a state of war on the roads, railways, and canals mentioned in Article 29.

There will be an exception to this principle only in that which relates to the transport of articles destined for a belligerent, and considered, in virtue of the law of nations, as articles of contraband of war.

Chapter VI.-Declaration relative to the essential Conditions to be observed in order that new Occupations on the Coasts of the African Continent may be held to be effective.

\section{ArTicle 34.}

Any Power which henceforth takes possession of a tract of land on the coasts of the African Continent outside of its present possessions, or which, being hitherto without such possessions, shall acquire them, as well as the Power which assumes a Protectorate there, shall ascompany the respective act with a notification thereof, addressed to the other Signatory Powers of the present Act, in order to enable them, if need be, to make good any claims of their own.

\section{Article 35.}

The Signatory Powers of the present Act recognize the obligation to insure the establishment of authority in the regions occupied by them on the coasts of the African Continent sufficient to protect existing rights, and, as the case may be, freedom of trade and of transit under the conditions agreed upon. 


\section{Chapter VII.-General Dispositions.}

\section{Article 36.}

The Signatory Powers of the present General Act reserve to themselves to introduce into it subsequently, and by common accord, such modifications and improvements as experience may show to be expedient.

\section{Article 37.}

The Powers who have not signed the present General Act shall be free to adhere to its provisions by a separate instrument.

The adhesion of each Power shall be notified in diplomatic form to the Government of the German Empire, and by it in turn to all the other Signatory or adhering Powers.

Such adhesion shall carry with it full acceptance of all the obligations as well as admission to all the advantages stipulated by the present General Act.

\section{Article 38.}

The present General Act shall be ratified with as little delay as possible, the same in no case to exceed a year.

It will come into force for each Power from the date of its ratification by that Power.

Meanwhile, the Signatory Powers of the present General Act bind themselves not to take any steps contrary to its provisions.

Each Power will address its ratification to the Government of the German Empire, by which notice of the fact will be given to all the other Signatory Powers of the present Act.

The ratifications of all the Powers will be deposited in the archives of the Government of the German Empire. When all the ratifications shall have been sent in, there will be drawn up a Deposit Act, in the shape of a Protocol, to be signed by the Representatives of all the Powers which have taken part in the Conference of Berlin, and of which a certified copy will be sent to each of those Powers. 


\section{CHAPTER VI OF THE GENERAL ACT OF THE} BRUSSELS CONFERENCE, signed at Brussels, July 2, 1890.

Chapter VI.-Restrictive Measures concerning the Traffic in Spirituous Liquors.

\section{Article XC.}

Justly anxious about the moral and material consequences which the abuse of spirituous liquors entails on the native populations, the Signatory Powers have agreed to apply the provisions of Articles XCI, XCII, and XCIII within a zone extending from the 20th degree north latitude to the 22nd degree south latitude, and bounded by the Atlantic Ocean on the west and by the Indian Ocean on the east, with its dependencies, comprising the islands adjacent to the mainland, up to 100 sea miles from the shore.

\section{Article XCI.}

In the districts of this zone where it shall be ascertained that, either on account of religious belief or from other motives, the use of distilled liquors does not exist or has not been developed, the Powers shall prohibit their importation. The manufacture of distilled liquors there shall be equally prohibited.

Each Power shall determine the limits of the zone of prohibition of alcoholic liquors in its possessions or Protectorates, and shall be bound to notify the limits thereof to the other Powers within the space of six months. The above prohibition can only be suspended in the case of limited quantities destined for the consumption of the non-native population and imported under the régime and conditions determined by each Government.

\section{Article XCII.}

The Powers having possessions or exercising protectorates in the region of the zone which are not placed under the action of the prohibition, and into which alcoholic liquors are at present either freely imported or pay an import duty of less than $15 \mathrm{fr}$. per hectolitre at 50 degrees Centigrade, undertake to levy on these alcoholic liquors an import duty of $15 \mathrm{fr}$. per hectolitre at 50 degrees Centigrade for three years after the present General Act comes into force. At the expiration of this period the duty may 
be increased to $25 \mathrm{fr}$. during a fresh period of three years. At the end of the sixth year it shall be submitted to revision, taking as a basis the average results produced by these Tariffs, for the purpose of then fixing, if possible, a minimum duty throughout the whole extent of the zone where the prohibition referred to in Article XCI is not in force.

The Powers have the right of maintaining and increasing the duties beyond the minimum fixed by the present Article in those regions where they already possess that right.

\section{Article XCIII.}

The distilled liquors manufactured in the regions referred to in Article XCII, and intended for inland consumption, shall be subject to an excise duty.

This excise duty, the collection of which the Powers undertake to insure as far as possible, shall not be lower than the minimum import duty fixed by Article XCII.

\section{Article XCIV.}

Signatory Powers having in Africa possessions contiguous to the zone specified in Article XC undertake to adopt the necessary measures for preventing the introduction of spirituous liquors within the territories of the said zone by their inland frontiers.

\section{Article XCV.}

The Powers shall communicate to each other, through the Office at Brussels, and according to the terms of Chapter V, information relating to the traffic in alcoholic liquors within their respective territories.

\section{DECLARATION ANNEXED TO THE GENERAL ACT} OF THE BRUSSELS CONFERENCE, SIGNED JULY 2, 1890.

The Powers assembled in Conference at Brussels, who have ratified the General Act of Berlin of the 26th February, 1885, or who have acceded thereto,

After having drawn up and signed in concert, in the General Act of this day, a collection of measures intended to put an end to the Slave Traffic by land as well as by sea, and to improve the moral and material conditions of existence of native races, 
Taking into consideration that the execution of the provisions which they have adopted with this object imposes on some of them who have possessions or Protectorates in the conventional basin of the Congo, obligations which absolutely demand new resources to meet them,

Have agreed to make the following Declaration :-

The Signatories or acceding Powers who have possessions or Protectorates in the said Conventional basin of the Congo shall be able, so far as authority is required to this end, to establish duties upon imported goods, the scale of which shall not exceed a rate equivalent to 10 per cent. ad valorem at the port of entry, always excepting spirituous liquors, which are regulated by the provisions of Chapter VI of the General Act of this day.

After the signing of the said General Act, negotiations shall be opened between the Powers who have ratified the General Act of Berlin or who have acceded to it, in order to draw up, within a maximum limit of the 10 per cent. ad valorem, the system of Customs Regulations to be established in the conventional basin of the Congo.

Nevertheless it is understood :-

1. That no differential treatment or transit duty shall be established;

2. That in applying the Customs Regulations which are to be agreed upon, each Power will undertake to simplify formalities as much as possible, and to facilitate trade operations ;

3. That the arrangement resulting from the proposed negotiations shall remain in force for fifteen years from the signing of the present Declaration.

At the expiration of this term, and failing a fresh Agreement, the Contracting Powers will return to the conditions provided for by Article IV of the General Act of Berlin, retaining the power of imposing duties up to a maximum of 10 per cent. upon goods imported into the conventional basin of the Congo.

The ratifications of the present Declaration shall be exchanged at the same time as those of the General Act of this day. 


\section{CONVENTION RESPECTING LIQUORS IN AFRICA, signed at Brussels, November 3, 1906.}

\section{Article I.}

From the coming into force of the present Convention, the import duties on spirituous liquors shall be raised, throughout the zone where there does not exist the system of total prohibition provided by Article XCI of the General Act of Brussels to the rate of $100 \mathrm{fr}$. the hectolitre at 50 degrees Centigrade.

It is understood, however, as far as Erythrea is concerned, that this duty may be at the rate of $70 \mathrm{fr}$. only the hectolitre at 50 degrees Centigrade, the surplus being represented in a general and permanent manner by the total of the other duties of that Colony.

The import duty shall be augmented proportionally for each degree above 50 degrees Centigrade. It may be diminished proportionally for each degree below 50 degrees Centigrade.

- The Powers retain the right of maintaining and increasing the duty beyond the minimum fixed by the present Article in the regions in which they now possess that right.

\section{Article II.}

In accordance with Article XCIII of the General Act of Brussels, distilled drinks made in the districts mentioned in Article XCII of the said General Act, and intended for consumption, shall pay an excise duty.

This excise duty, the collection of which the Powers undertake to ensure as far as is possible, shall not be lower than the minimum import duty fixed by Article $I$ of the present Convention.

It is understood, however, as far as Angola is concermed, that the Portuguese Government shall be able, with a view to effecting the gradual and complete transformation of the distilleries into sugar factories, to deduct from the money raised by the duty of $100 \mathrm{fr}$. a sum of $30 \mathrm{fr}$., which shall be given to the producers on condition that they effect such transformation under Government control.

If the Portuguese Government make use of this facility, the 
number of distilleries working and the capacity for production of each one of them must not exceed the number and capacity certified on the 31st October, 1906.

\section{Article III.}

The provisions of the present Convention are to hold good for a period of ten years.

At the end of this period, the import duty fixed in Article I shall be submitted to revision, taking as a basis the results produced by the preceding rate.

Each of the Contracting Powers shall, however, have the option of calling for such a revision at the end of the eighth year.

Such Powers as shall make use of this option must notify their intention six months before the date of expiry to the other Powers through the intermediary of the Belgian Government, who shall undertake to convoke the Conference within the six months above mentioned.

\section{Article IV.}

It is understood that the Powers who signed the General Act of Brussels or who have acceded to it, and who are not represented at the present Conference, preserve the right of acceding to the present Convention.

\section{Article V.}

The present Convention shall be ratified, and the ratifications shall be deposited at the Ministry for Foreign Affairs at Brussels within the shortest possible period, and such period shall not in any case exceed one year.

A certified copy of the procès-verbal of deposit shall be addressed by the Belgian Government to all the Powers interested.

\section{Article VI.}

The present Convention shall come into force in all the possessions of the Contracting Powers situated in the zone defined by Article XC of the General Act of Brussels on the 30th day after the date of the termination of the procès-verbal of deposit mentioned in the preceding Article.

From that date, the Convention regulating the question of spirituous liquors in Africa, signed at Brussels on the 8th June, 1899 , shall cease to have effect. 
V. DECLARATION MODIFYING PARAGRAPH 5 OF THE DECLARATION ANNEXED TO THE GENERAL ACT signed at Brussels July 2, 1890, signfid at Brussels JUNE 15, 1910.

The Powers which have ratified or acceded to the Berlin General Act of the 26th February, 1885, have agreed to make the following Declaration :-

In modification of paragraph 5 of the Declaration annexed to the Brussels General Act of the 2nd July, 1890, the Powers which signed that Act or acceded thereto, and which have possessions or protectorates in the Conventional Basin of the Congo, are authorised, so far as such authorisation is necessary, to impose therein upon imported arms and munitions duties exceeding the maximum limit of 10 per cent. of the value at the port of importation, fixed by the aforesaid Declaration.

The present Declaration shall be ratified and the Ratifications shall be deposited at the Ministry for Foreign Affairs at Brussels within a period of one year or sooner if possible.

It shall come into force on thirty days after the date on which the Protocol recording such deposit shall have been closed. ${ }^{1}$

1 This took place on December 31, 1911 (Cd. 6037, p. 112). 


\section{INDEX}

Ababuas, operations in 1900-2 against, 115.

Abandas submit in 1892, 104.

Abercorn, proposal to connect with Broken Hill by railway, 278.

Abir Company, 122, 149, 207, 251.

Aborigines Protection Society investigates action of Congolese officials, 128, 129.

Abrogation of treaties by act of war, clauses of Berlin Act to be exempt from, 282, 305, 307, 312, 313, 315; Franco-German treaty of 1911 annulled, 275.

Act of Navigation for the Congo, $59,60,306-12$.

Act of Navigation for the Niger, 62 , 313-15.

Additional Act of Cession of the Congo, 142; disposal of grants under, 232.

Administrative officers, appointment of, to judicial offices, 119, 124.

Administrators-General of the Congo, 116.

Afghanistan, difficulties as to, in $1884-5$ as affecting British policy, $37,56$.

Afrikaansche Handels-Genootschap, $38,39, \mathrm{n} .2$.

Afrikaansche Handels-Vereeniging, 28,39, n. 2.

Aga Khan, H. H. the,supports Indian settlement in German East Africa, 290, n. 2.

Agricultural Bank, necessity of, 264 .

Agriculture, 160, 161, 243-6.

Akalunga, Cape, 87.

Albert I, King of the Belgians, reforms in Congo instigated by, $5,15,146,276$.

Alberta, Messrs. Lever's factory at, 245.

Albertville, 85, 171.

Alima, 43, 45, n. 1 .

Alvensleben, Count, German Minister at Brussels, note to Congo
State regarding freedom of trade, 164.

Ambriz, Portuguese claim to, 23, 24.

American Baptist Missionary Union, 128, 218, 219.

American Congo Co., 251.

American Indians in Canada, land rights of, 204.

American Presbyterian Mission, 128, 219.

Anglo-French Declaration of March 21, 1899, 111, 282.

Anglo-German treaties of 1890 and 1893 recognize British claim to control of the Nile, 113, n. 3 .

Angola, occupation of, by the Portuguese, 20, 22; liquor tariffs in, 81,320 ; Portuguese efforts to secure connexion with Mozambique, 22, 54; diamond working in, 247 ; only in part in free-trade zone, 283; high tariffs and exclusive land policy in, 300 .

Angra Pequena, British attitude as to, 55,56 .

Animism, prevailing religious view in the Congo, 224.

Annexation of the Congo by Belgium, 16, 137-44; conditions of, $145,146$.

Annexations on African Coast, principles of Berlin Act affecting, 61, $62,315$.

Annual Report on the Congo, presented to Belgian Parliament, 178.

Antimalarial measures, 232.

Antwerp, ivory market at, 245.

Anzico, Great Makoko of the, 24, 25.

Apostolic Prefectures, 220.

Apostolic Vicarage of the Congo, 220 ; at Stanley Falls, 220 ; of the Upper Congo, at Tanganyika, 220.

Apiculture on the Kasai, 244.

Arab influence on the Congo, 29, $30,225-7$. 
Arabisés, character of, 225, 226.

Arbitration in disputes under Berlin Act, 284-5, 298-9.

Archbishop of Canterbury supports movement for Congolese reforms, 145.

Armourers, corps of, 120.

Arms and ammunition traffic, 79, 80,216-17,293, 322; possession of flint guns by the natives, 234 .

Avrêté, signification of, 117, 175-6.

Arthington, Mr., supports British Missionary Society, 217, 218.

Artomoroff, Russian officer, expedition from Abyssinia to the Nile in $1897-8,111$.

Aruwimi, 75, 97, 121, 156, 225, 247. Aruwimi, district of the Eastern Province, 186.

Atrocities, committed on both sides in anti-slave-trade campaign, 98 ; in German Colonies, 12, 16, 288 , n. 2 ; on the Congo, 5, 131$2,147$.

Austria-Hungary, participates in the Berlin Conference, 57; in the Brussels Conference, 78, n. 3 ; treaty with the International Association, 63; - inaction in Rabinek case, 89.

Baert, expedition to the Ebola and Dua, 103.

Bahr el Ghazal, Belgian interests in the, 101-2, 112-13, 131.

Balfour, Rt. Hon. A. J., Secretary of State for Foreign Affairs (1915- ), on return of German Colonies to Germany, 300.

Bamu, neutrality of island of, in Stanley Pool, 110, 144.

Banana, 220, 231, 242.

Bangala, district of the Equator Province, 186.

Bangalas, recruits raised from, for Congolese army, 121.

Bangasso, ruler of the Sakaras, 103. Bangi, French post at, in 1889, 105.

Bangweolo, Lake, 26, 86, 87.

Banjas submit in 1892, 104.

Bank of the Belgian Congo, 200.

Bankruptcy, law of, 268.

Banning, Emile, assistant to Belgian delegation at the Berlin Conference, 57.
Bantu tribes in the Congo, 18.

Banzyville, 76.

Baptist Missionary Society, 25, 217, 218.

Barracouta, H.M.S., surveys estuary of the Congo, 25.

Barristers not required in Congolese courts, 194.

Barttelot, Major, death of, in charge of Stanley's rearguard, 76.

Barumbu, 245.

Basankusu, market for copal at, 244.

Basoko, 97.

Bastian, Dr., rediscovers San Salvador in 1857, 24.

Batetelas, revolt of the, 99, 100 ; religion of, 226.

Beaconsfield, Earl of, refuses to adopt active policy as to the Congo, 27, n. 1, 35.

Beernaert, attitude of, on Congo question, 139.

Beira, railway route via, 160,239 , 243, 263.

Beira and Mashonaland Railway Co., 243.

Beit, Mr., negotiations with $\mathrm{Mr}$. Williams as to a railway through the Congo, 240.

Beit Trustees aid connexion of the Congo with the Rhodesian railway, $91, \mathrm{n} .1$.

Belgarde, Abbé, mission to the Luango Coast in 1766, 21.

Belgian Anti-Slave-Trade Society, 86,94 .

Belgian citizenship not accorded to natives of Congo, 178.

Belgian Commission of Enquiry into maladministration of the Congo, 132-4 ; on abuses in educational system, 221, 222.

Belgian Courts, relation to Congolese courts, in civil matters, 268 , 269 ; in criminal matters, 271 , 272.

Belgian priests, early missions of, to the Congo, 21.

Belgian soldiers may not serve in the Congolese forces, 178, 189.

Belgian trade with the Congo, development under the concessionary régime, 127, 128, 251, 252, $285,286$. 
Belgians not liable to conscription for service in the Congo, 189 .

Belgium, relation to International African Association, 33-5; takes part in Berlin Conference, 57; recognizes the International Congo Association, 63 ; permits Leopold II to assume sovereignty, 66 ; subsidizes Congolese railway, 71; loan to Congo, 76, 77; trade gains from Congo, 127, 128, 251, 252; annexes Congo, 137-44; dispute with United Kingdom, 145-58 ; relations with Germany, 162-74; control of Congo, 175, 176 ; in the matter of concessions, 205,206 ; arms traffic, 216 ; relation of Belgian to Congolese courts, 268, 269, 271, 272 ; moral claim to government of Congo, 273-81; disadvantages of neutrality, 295, 296; support from France and United Kingdom, $301, \mathbf{n} .1$.

Bentley, George, Baptist missionary, driven from Stanley Pool, 44; linguistic studies, 218.

Béon, Capt., captures Zinga in 1914, 172.

Berbers separated from negroes by Sahara, 283.

Berlin Act, 57-65; proposals for revision of, in light of history, 282-301; text of, 302-16; and see Free Trade, Liquor traffic, Monopolies, Neutralization, Treatment of natives.

Bia, successful expedition in 18912 to the Katanga, 86.

Bio, his territory occupied by Lemaire, 113.

Bismarck, Prince, encourages French opposition to British interests on the Congo, 53-6; nominal President of the Berlin Conference, 57, 62, 66.

Bissing, Count yon, testament of, regarding Belgium, 143, n. 2.

Bitima, 104.

Boards of Health, 231.

Bodson, Lieut., kills Msiri, 86.

Böhm, German explorer, travels in the South Congo basin, 53.

Bokusu (Bakusu), 226.

Boma, 25, 100, 181, 209, 228, 242.
Bomokandi, 103, 104.

Bonalia, 247.

Bonchamps, abortive expedition from Abyssinia to the Nile, 111.

Bonga captured by French forces in 1914, 172.

Bopoto, 121.

Botanic Garden at Eala, 229, 246.

Botha, Gen. Rt. Hon. L., supports claim of Union to German South Africa, 283, n. 5 .

Boundaries of the Congo, 64, n.4, 67, n. 2, 73-4, 105-10, 162-3.

Bourne, H. R. Fox, on misgovernment of the Congo, 129.

Bourse du Travail du Katanga, 255.

Brasseur, commandant at Lofoi, 87.

Brazza, Savorgnan de, rivalry with Stanley, 42-5, 48, 49.

British East Africa Company, 33, n. 1; informal agreement as to territorial exchanges with Leopold II, 102 ; proposed Indian settlement in, 290 , n. 2.

British South Africa Co., 84, 255 ; native land policy, 14, 290; assists railway connexion with the Katanga, 91, n. 1.

British trade, decline of, in Congo in comparison with that of Germany, 252-3 ; hampered by concessionary régime, 127-8,2856 ; disadvantages to, of protectionist régime in the French Congo and other French possessions, 282-3; of concessionary régime in the French Congo, $285-6$.

Broken Hill, railway communication with, 239-40; proposal to connect with Abercorn, 278.

Brusciotta, Giacinto, Apostolic Prefect of the Congo, compiles vocabulary of Congolese words, 21.

Brussels Conference, 1889-90, 77$80,286,317-18$; Brussels Conference, 1899, 81, 321 ; Brussels Conference, 1906, 81, 292, n.2, 320-1 ; Declaration, 1910, 322.

Budget of the Congo, 196.

Bujas, revolt of the, 100 .

Bukama, 174, 237, $239,248$.

Bumpa (Bumba), 121, 245.

Bunkeia, Msiri's capital, 85-6. 
Burton, Sir Richard, visits Yalala falls in 1863, 26.

Bushman stock in the Congo, 18.

Buxton, Sir Fowell, Bart., G.C.M.G., sympathizes with Leopold II's African schemes, 33.

Cameron, Lieut. V. L., explorations in the Congo, 27-8.

Cameron Bay, 87.

Cameroons, 170-1, 296.

Campbell, G., reports on Katanga affairs, 152, n. 1, 157-8, 162, n. 1 .

Cannibalism, on the Congo, 29; punishment of, 195.

Cão, Dom Diogo, enters the mouth of the Congo, 19.

Cape of Good Hope, occupation of, by Great Britain excites Portuguese rivalry, 22; delays of government result in loss to Germany of South-West Africa in 1884, 56, 283.

Cape to Cairo Route, scheme for, $106,165,168,240,277-8$.

Capital, necessity of, for Congolese development, 262-3:

Capuchin monks, missions of, to the Congo, 21.

Carnarvon, Earl of, declines to annex the Congo, 27, n. 1 .

Casement, Sir Roger, indictment of Congo régime, $16,131-2$; value of his evidence, 273.

Cash, importance of introduction of payments in, as a measure of reform, 149, 151, 154.

Cattier, F., works on the Congo, 6 .

Cattle-breeding, near Kivu, 244; in the Katanga, 91, 161-2.

Cavazzi, Father; 21.

Ceara (Manihot Glaziovii), cultivation of, 261.

Cecil, Lord Robert, reply to Dr. Solf on German. Colonies, 10, n. 3, 300, n. 2.

Central Africa, from the Sahara to the Zambezi, view of Labour Party on government of, 279-81.

Central African Empire, German ideal of (cf. E. Zimmermann, The German Empire of Central Africa, trans. by E. Bevan, 1918), 9, 167, 276.
Central government of the Congo, expense of, 199, n. 1 .

Centralization of government, excessive, 117, 184, 186.

Cercle africain supports annexation, 138.

Chaltin expedition to Nile, $97, \overline{1} 12$, 115.

Chambezi, 26.

Chargeurs réunis, French Steamship Co., 242.

Chickwangues, 149.

Chiloango, 239.

Chitambo's, place of David Livingstone's death in $1873,27$.

Christian Disciples Mission, 219.

Christian Kingdom of the Congo, 19-22.

Christian Missionary Alliance of New York, 219.

Christy, Major, articles by, referred to, 261, n.2, 278, n. 1 .

Civil Courts, under the State régime, $118-19,135$; under the Colonial régime, 193.

Civil Law and Procedure, 265-9.

Civil Service, reform of, 152, 188-9; members of, encouraged to take wives to the Congo, 230; health of, 232.

Civil status, regulation of, 265 .

Clarendon, Earl of, declines, to recognize Portuguese claims on the Congo, 24.

Coal in the Lukuga valley, 248.

Cocoa, cultivation of, in Mayumbe district, 244-5, 262.

Code civil, 209, n. 2, 265.

Code pénal, 269-70.

Coffee, cultivation of, 96, 245, 262.

Collective property, doctrine of, 208-10, 215, 233.

Colonial Charter, provisions of, 122 , $152,159,177-9,196,205,209,232$, 235, 268, 271.

Colonial Council, at Brussels, advisory, created by Leopold II, 135 ; reconstituted under the Charter, 176.

Colonial Garden at Laeken, 183,227. Colonial Office, organization of, 183. Colonial School at Brussels, 183, 188-9.

Colonial Society of Brussels creates Laboratory at Leopoldville, 231. 
Comber, Mr., Baptist missionary, 218.

Comité d'action pour l'œuvre nationale africaine supports acquisition of the Congo, 138 .

Comité d'Études du Haut Congo, 38 ; aims of, 39,40 ; transformed into International Association of the Congo, 45.

Comité spécial du Katanga, 88, 15960 ; land rights of, 207 ; mining rights of, 247-8.

Commercial agents, under the Charter, may not be entrusted with administrative functions, 177:

Commercial and political functions, combination of, 147 ; prohibited by Colonial Charter, 152.

Commercial legislation, 267, 268.

Commission for the Protection of the Natives, abortive decree of 1896, 126, 232.

Commission for the Protection of the Natives, under Colonial Charter, 232-5.

Commission of Enquiry into atrocities on the Congo, 132-4; condemnation of fermes-chapelles, $221,222$.

Commissioners of Districts, under the State régime, 118; under the Colonial régime, 185-6, 208.

Communications, 236-43.

Compagnie belge maritime, 242 .

Compagnie des chemins de fer du Congo supérieur aux Grands Lacs, 155-6, 237, 247, 251.

Compagnie du chemin de fer du BasCongo au Katanga, 238, 241, 247.

Compagnie du chemin de fer du Congo, 71, 236.

Compagnie du chemin de fer du Katanga, 237-8.

Compagnie du Congo pour le Commerce et l'Industrie, 71, 250-1.

Compagnie du Katanga, 84, 88-90, 122, 160, 251.

Compagnie du Lomami, 85 , n. 1, 155, 251.

Compagnie foncière, agricole et pastorale du Congo attempts to introduce settlers, 161, 245.

Companhia da Nyassa, 255.

Companies, law affecting, 267, 268.
Comptoir commercial Congolais, 251.

Comptoir national d'escompte, of Paris, obtains concessions in the Congo, 249.

Compulsory work, alleged justification of, in case of natives, 133.

Concessionary régime in the Belgian Congo, injury to British trade, 127, 128, 285, 286 ; in the French Congo, 150, 151, 285, 286.

Concessions, necessity for legislative sanction of, 176 ; principles affecting grant of, to nonnationals, 286, 287.

Concordat with the Holy See, May 26, 1906, 222, 229.

Congo, railway route via the, 160 , $239,243,263$.

Congo Balolo Mission, 219.

Congo-Kasai, province of, with districts of Lower Congo, Middle Congo, Kwango, Kasai, and Sankuru, 186.

Congo Reform Association, 129, $133,135$.

Congrégation du Cœur immaculé de Marie, 220.

Congrégation du Saint-Esprit,219, 220.

Congress of Vienna, principles as to navigation of great rivers laid down by, 55.

Conseil supérieur du Congo, functions of, 117, 126, 183, 193 ; official language of, 179 ; execution of judgements of, 271 .

Consular jurisdiction, right of the United Kingdom and other powers to exercise in the Congo, 63; waived in practice, 67,68 ; suggestion that it should be formally abandoned, 278.

Consultative Councils in the Congo, $118,184,185$.

Contracts for public purposes, question of restriction of, to nationals, 286, 287.

Converts to Christianity, 223.

Copal, as taxation, 148; development of trade in, 244.

Copper in the Katanga, 248.

Coquilhat adrocates State trading by the Congo, 121. 
Coquilhatville, 185, 242.

Corporal punishment, limitation on power of chief to order, 195.

Corvées, under State, 148; abolished under Colonial régime, 153.

Cotton, cultivation of, 245, 262.

Councils of War, under State régime, 118, 119 ; under Colonial régime, 193.

Cour des Comptes, at Brussels, examines accounts of the Congo, 176, 197.

Courcel, Baron de, representative of France at the Berlin Conference, 57.

Courts of Appeal, jurisdiction of, 193.

Courts of First Instance, 192, 193.

Courts of the Public Prosecutor, jurisdiction of, 191, 192, 193.

Crewe, Brig.-Gen. Sir Charles, K.C.M.G., services in German East Africa, 172.

Criminal Courts, under the State, 118,126 ; under the Colony, 191-3.

Criminal Law and Procedure, 26972.

Cromer, Earl of, British Agent in Egypt, disapproves Gordon's proposals to proceed south, 101, 102 ; report on condition of the Lado enclave under Belgian rule, 115 ; criticizes State régime, 135.

Crudgington, Mr., Baptist missionary, driven away from Stanley Pool, 44, 218.

Currency, 199, 200.

Customsdutiesand imposts, product of, reserved for Colonial use, 177 ; rates of, 198; and see Import duties.

Dahomey, liquor tariff in, 81 ; proposal to neutralize, 169 ; British trade rights in, 282.

Daily Telegraph, Stanley's expedition on account of, 36,37 .

Dar-es-Salaam, railway route from, 239.

Darfur, British claim to, 113, n. 3.

Davignon, J., Belgian Minister for Foreign Affairs, 145, 170, 210, n. 1, 211, n. 1, 212.
Deane, Captain, attacked at Stanley Falls, 74 .

de Bruyne murdered at Kasongo, 96.

Decazes, modus vivendi with Le Marinel concluded by, 106.

Declaration of Neutrality, of Congo territory of Aug. 1, 1885, 67; of Dec. 28, 1894, 110.

Declaration of Paris, 1916, 300.

Décret, 117, 175.

De la Kéthulle, expedition of, 104.

Delanghe defeats Dervishes at Mundu, 104.

deLantsheere, President of the Commission on the Annexation of the Congo, 138.

Delbrück, Professor H., views on German Colonies, 9, n. 1.

Delcommune, expedition of, 84,85 . de Mérode, resignation of, on Congo question, 138, 139.

Denmark, participates in the Berlin Conference, 57 ; in the Brussels Conference, 78, n. 3; treaty with the International Association, 63.

Department of Agriculture, 245, 246.

Derby, Earl of, attitude of, to Portuguese claims in Africa, 50.

d'Erlanger, Baron E. B., 91, n. 1, 239, n. 2, 248, n. 1.

Descamps defeats Gongo Lutété, 94.

Deserted children, control and education of, 221, 222, 227, 228.

de Souza, Roderigo, mission to the Congo in 1490, 19.

Destruction caused by anti-slavetrade war, 96, n. 2.

de Trooz, Premier of Belgium, 141.

Deutsche Bank obtains concessions in the Congo, 249.

Dhanis, Baron, campaigns in the Congo, 73, 84, 97-9, 111, 112.

Diamonds on the Kundelungu plateau, 248.

Dilke, Rt. Hon. Sir Charles, Bart., comments on atrocities in the Congo, 128, 132, 133.

Dilolo, 238.

Dirfi, revolt at, 99.

Disregard for authority by natives, $234,264$. 
Districts, 118, 185, 186.

Divorce, regulation of, 266 .

Domain forests, control of, 208.

Domain lands, 204-8.

Domaine de la Couronne, 122 ; converted into Fondation de la Couronne, 135; suppressed, 141, 142.

Domaine privé or national, 122, $135,153-4,204-8$.

Domestic slavery, 213, 214.

Domestication of the elephant, experiments in, 246.

Domicile, law of, 266.

Donceel reaches Lifi, 104.

Donckier reaches Lifi, 104.

Droit administratif in the Congo, 153, 289.

Dua, 103.

Duchesne, judicial murder of Gongo Lutété by, 97; 99.

Dufilé, 104.

Dungu, Belgian post at, 115.

Dutch trade with the Congo, decline of, 127, 253.

Duties on imported liquors, 78, 79, $81,82,317,318,320,321$.

East India Company, legal position of the, 49.

Eastern Province, with districts of Lower Uele, Upper Uele, Ituri, Aruwimi, Stanleyville, Kivu, Lowa, and Manyema, 185.

Ebola, 103.

Education, 227-30.

Egaru, Belgian victory on the, 104 .

Egypt, slave trade on account of, 29 ; difficulties as to, in relation to British policy, 37, 55, 56; claim to the Sudan, 104.

Elder Dempster \& Co., 242, 243.

Electric power, possibility of development of, 262.

Elephants, reserve for, in the Uele district, 246.

Elizabetha, 245.

Elizabethville, 189, 239.

Elliott, Capt. J. G., founds stations on the lower Niari, 46.

Emin Pasha, rescue of, by Stanley, $75,76,102$; death of, 96 .

Equatoria, under Emin Pasha, 75, 76, 102.

Equator, Province of, with districts of Ubangi, Bangala, Lulonga,
Equator, Lake Leopold II, 185 ; military school at, 120.

Erythrea, liquor taxation in, 81, 320.

Ethiopia adheres to the Brussels Act, 1890,78, n. 3 .

European farmers, proposal to settle in the Katanga, 161, 245.

European relations with the Congo, early records of, 18, 19.

Executive force, under the State régime, 117; under the Colonial Constitution, 175, 183.

Expenditure, 199.

Export duties, 198; not limited by Berlin Act, 288.

Exports, 251, 252.

Fashoda, Anglo-French incident at, in $1898,111,138$.

Faure, Félix, President of the French Republic, relations with Leopold II,.111, 138.

Fédération pour la défense des interêts belges à l'étranger, 129 .

Fermes-chapelles, system of, 156, $222,223$.

Ferry, Jules, hostile policy of, towards the United Kingdom, 56 .

Finances, 196-200.

Fiscal matters, jurisdiction of ordinary courts over, 193.

Fishing industry, 246.

Fitzmaurice, Lord E., criticizes the Congolese administration, 132.

Flag of the International African Association and of the Congo State,35; of the Belgian Congo, 178.

Flemish language, position of, in the Congo, 173.

Fondation de la Couronne, replaces Domaine de la Couronne, 135; suppressed, 141, 142.

Fondation de Niederfullbach, 141.

Food products introduced by the Portuguese, 25.

Foreign companies, position of, 268 .

Foreign judgements, recognition of, 269.

Foreign relations of the Congo controlled by Belgium, 175 .

Foreigners, position of, under Berlin Act, 59, 304 ; death of Rabinek, 89, 90 ; of Stokes, 125, 126. 
Forests, 154, 244.

France, interests on the Congo, 28, $48,53,54,56$; takes part in Berlin Conference, 57; boundary with Congo, 63, 64, 72, 73 ; customs treaty of 1892, 81; question of northern frontier and the Nile, 104-14; criticism of Congolese administration, 129 ; right of preemption, 138, 144, 273 ; relations with Germany, 165-7; war with Germany, 169-72; arms traffic, 216 ; shipping, 242,243 ; claim to reversion of the Congo, 274, 275 ; protective policy in her colonies, 282, 299, 300; and see French Congo.

Franceville founded by de Brazza, 43.

Franciscan Recollets, mission of, to the Congo, 21.

Franco-German treaty of Nov. 4, 1911 (supplemented by agreement of Sept. 28,1912), 166, 167 ; abrogated by the war of 1914, 275.

Francqui brings Bia's expedition back to Lusambo, 86 .

Free Church Council protests against Congolese administration, 130.

Free Trade,question of, under Berlin Act, 58-60, 68, 120-3, 130, 131, $133,150,151,164,165,254,285$, $286,302,303$.

French Congo, protectionist régime in part of, 14, 283; abuses in, under concessionary régime, 150 , $151,155,286$; necessity of wider powers of taxation of imports into, 288.

French Guinea, disadvantages to British trade of protectionist régime in, 283.

French language, position of, in the Congo, 173.

French missionaries in the Congo, $21,220$.

French Sudan, disadvantages to British trade of protectionist régime in, 283.

French trade with the Congo, 253.

French West Africa, connexion with Equatorial Africa, affected by treaty of 1911,169 .
Frere, Rt.Hon. SirH. Bartle,G.C.B., G.C.S.I., appointed a member of the Executive Committee of the International African Association, 33 ; withdraws, 35 , n. 1.

Fuchs, M., Governor-General of the Congo, 171.

Funtumia elastica (Ireh), 261.

Gaboon, French offer to exchange for the Gambia rejected in 1868, 26 ; isolated from the Middle Congo by Franco-German treaty of 1911,166 ; disadvantage to British trade of protectionist régime in, 283.

Gambetta, interest taken by, in Stanley's proposals as to the Congo, 38.

Gandu, 94.

General Conference of Evangelical Missionaries protests against atrocities on the Congo, 223, n. 1.

German East Africa, campaign against, 11, 169-74, 296 ; slavery in, 214; proposal to discourage Mohammedanism in, 13, 227; Belgian claim to portion of, 277; British claim, 278.

Germany, interests on the Congo, $28,53-6$; participation in Berlin Conference, 57 ; in Brussels Conference, 78, n. 3 ; relations with United Kingdom, 107-8; action in Stokes's case, 125, 126; designs on the Congo, 162-9; war with Belgium, 169-74; arms traffic, 216 ; shipping, 242-3 ; trade aims, 249,252, 253, 261-3 ; propaganda against Congo, 273 ; misgovernment of native races, 12 , $16,276,277,288$; ill-treatment of European prisoners in Africa, 288 , n. 1 ; claim to territorial possessions in Africa, 275-7, 300. Ghent, mission of secular clergy of, at the Cataracts, 221.

Giagas, in vasion of, in 1570, 19.

Gibbons, Cardinal, supports Congolese administration, 130, n.2.

Gillain settles disorders consequent on murder of Gongo Lutété, 97.

Gladstone, Rt. Hon. W. E., announces evacuation of the Soudan, 102, n. 1 . 
Gold, 247, 248.

Gold Coast, proposal to neutralize, in the war of 1914-18, 169, 170; prosperity under British rule, 13; French trading rights in, 282.

Goldie, Sir George T., K.C.M.G., secures British influence on the Niger, 58.

Goldsmid, Sir Frederick, visit to the Congo, 47.

Gongo Lutété, services of, to the Belgians, 93, 94, 96, 97, 99.

Gordon, General, appointed to succeed Stanley on the Congo, but throws up appointment, 47; designs against slave-traders, 70 , 101 ; fall of, 75.

Gordon Bennet river, territory on, ceded to de Brazza, 42.

Governor-General, under State régime, 117; under Colonial régime, 183-5; duty of protecting the natives, 233.

Graf von Götzen destroyed in 1916, 173.

Grandy, Lieut., R.N., expedition of, in search of $\mathrm{D}$. Livingstone, 27.

Grant, explorations of, on border of the Congo, 83.

Granville, Earl of, doubts as to Leopold II's policy, 32, n. 1; negotiates treaty with Portugal of $1884,50$.

Great Lakes, beds of, public property, 205.

Grenfell, G., Baptist missionary, 126,153, n. 2, 218, 219, n. 2 ; Sir Harry Johnston's life of, 6 .

Grey, Rt. Hon. Sir Edward (now Viscount), views on the Congo, 5 , $135,136,145,158,168$, n. 1,211 ; on League of Nations, 281, n. 3 .

Grey,George, prospects for minerals in the Katanga, 90.

Guinness, D., supports the Livingstone Inland Mission, 218.

Gum, see Copal.

Half-caste children, education of, 230.

Hamburg, makes a bid for Congolese trade, 252 ; centre of palm kernel trade, 261.

Hamed bin Muhammad bin Juma, alias Tipu-Tipu, 75, 92, 93.
Hanolet, expeditions of, 76, 104,111, $112,113$.

Hanotaux, M., unsuccessful negotiations with the Congo State, 106; attack on the Congo government, 109.

Hanssens, Capt., acquires territory on the upper Niari, 46.

Harcourt, Rt. Hon. L. (now Viscount), Secretary of State for the Colonies (1910-15), action in regard to Nigeria liquor tråffic, 293.

Harris, J. H., views cited, 152, n. 3 , 281, n. 1, 291, n. 1.

Hartland, Mr., Baptist missionary, 218.

Havash Montasser, raids on slavetraders, 103.

Health of European population, 232,260 ; of natives, $231,232$.

Hedwig von Wissmann bombards Albertville, 170, 171.

Hemp, introduced into the Congo from the north-east, 25 ; use of, prohibited, 195.

Henri, expeditions on the Nile, 112 .

Hermann von Wissmann captured in 1916, 173.

Hevea braziliensis, cultivation of, 261.

Hewett, Admiral Sir William, suppresses piracy at the Congo mouth, 26, n. 1.

Hinde, Capt., serves in anti-slavetrade campaign, 96, n. 2, 97.

Hinde Falls, 236.

Hindenburg, Marshal von, views on German colonies, 9 .

Hodister, ill-fated expedition of, to the Katanga, 85, 95.

Holland, participates in the Berlin Conference, 59 ; in the Brussels Conference, 78, n. 3 ; treaty with the International Association, 63; decline of trade with the Congo, 127,253 ; policy in Java, 124, 125.

Homeyer, Capt. von, suggests annexation of the Congo to Germany, 28.

Hostages, taking of, as means of exacting taxation from the natives, 124. 
Human sacrifices, in the Congo, 29, 224 ; punishment of, 195 ,

Hunting, regulations affecting, 246.

Hymans, M., views on Congolese questions, 156, n. $3,167$.

Ibembo, post founded by Roget, 103 . Immigration, regulation of, 180, 181.

Imperial Resources Development Commission, schemes of, as affecting West Africa, 298, 299.

Impila, boundary of territory ceded to de Brazza, 42.

Import duties, in the Congo, 77-9, $254,303,304,318-22$; necessity of relaxing restrictions on imposition of, 288.

Imports, 251, 252.

Independence of the Judiciary in the Congo, 177, 194.

Independent Labour Party, views on Colonial questions, 10, n.2, 280.

Indian labour not introduced into the Congo, 255.

Indian settlement in German East Africa, 290, n. 2.

Individuals, right of, to acquire territory in sovereignty, 49,50 .

Industry, 243-50.

Inkisi, 216, 239.

Inspectors of Commerce and Industry in the Katanga, 249.

Integrity of the Turkish Dominions, principle of, 105.

International African Association, 33-6; relation to Comité d'Études du Haut Congo, 38, 39; takes over responsibility for its actions, 45 .

International Association of the Congo, origin of, 45 ; relation to International African Association, 49 ; territorial claims, 49 , 51 ; recognized as a sovereign power, $62-5$; cedes its rights to Leopold II, 67; validity of its grant of right of pre-emption to France, 275, n. 1.

International Commission for the control of the navigation of the Congo, 59, 60, 297, 298, 309-12.

International Commission, proposal to entrust government of Central Africa to, 280, 281.
International Council, proposed creation of, for examination of African problems, 293, 294.

International law, question of rights of United Kingdom under, to demand just treatment of natives in the Congo, 146; necessity of alteration of Berlin Act in this regard, 284, 285.

Ireh (Funtumia elastica), cultivation of, 261.

Iron, 247.

Isangi, 95 ,

Isangila, road from Vivi to, 41, n. 1 . Italian missionaries in the Congo, 21.

Italy, relation to International African Association, 33, 34 ; participation in the Berlin Conference, 59 ; in the Brussels Conference, 78, n. 3 ; treaty with the International Association, 63, 68; criticizes Congolese administration, $129,131$.

Itimbiri river, 103, 247.

Ituri, district of the Eastern Province, 186.

Ivory, 68, 120, 121, 128, 154, 197, 245 ; registration of, 254 .

Jabir, relations with Belgians, 103, $104,115$.

Jacquemyns, M. Rolin, view on international position of the Congo State, 64, 65.

Jacques, Capt., leader of Anti-Slavetrade expedition to Tanganyika, $85,86,94,95,98,164$.

Jaggas, invasion of, in 1570, 19.

Janssen, C., Governor-General of the Congo, 6, 70, 73, 74, 93, 103, 122. Janssens, E., member of Belgian Commission of Enquiry, 132.

Java, fiscal system of, in 1830-70, $124,125$.

Jesuits, missionary activity in the Congo, 220.

Johnston, Sir Harry, G.C.M.G., George Grenfell and the Congo, 6; views on various points cited, 11 , n. 2, 52, 274, n. 1, 293.

Jouret, accompanies Hodister's mission, 95.

Judicial police, 194.

Jute, 245. 
Kabalo, 174, 237.

Kabambaré under Moini-Hamis, 92.

Kabinda, Portuguese claims to, 22 ; recognized in 1885, 64 .

Kabulula Falls, 236.

Kallengue Falls, 236.

Kambove, 91.

Kamina, German wireless station at, $169,171$.

Karema, post founded by the International African Association, 36.

Kasai, 25, 26, 122, 154, 237, 244, 247.

Kasai Company, 154, 207.

Kasai district of Congo-Kasai Province, 186.

Kasembe, 91.

Kasongo, 93, 95, 96, 242.

Katanga, a native chief, father-inlaw of Msiri, 83.

Katanga, occupation of the, 83-91; development of, 159-62; pass law in, 181,182 ; railways in, 237-9; mining in, 247, 248; labour in, 255, 256 ; prospect of European settlement in, 161, 245,260 ; British interests in, 277, 288.

Katanga, Province of the, with districts of Upper Luapula, Lulua, Tanganyika-Moero, and Lomami, 185.

Katuaka, 104.

Kero, post at, occupied by Chaltin, 112.

Kiambi, tin at, 248.

Kibali, 104.

Kibongé, ruler of Kirundu, 92 ; defeats of, 97,98 .

Kichimbi, 94.

Kigoma, capture of, by Belgian forces, 172,173 ; possible acquisition by Belgium, 239 .

Kilo, government gold mine at, 247.

Kilonga, 92.

Kilwa, island of, assigned by treaty of 1894 to the United Kingdom, 87.

Kimberley, Earl of, defence of treaty of May 12, 1894, 108, 109, n. 1; view on validity of French right of pre-emption, 275, n. 1 .

Kindu, 236, 237.

Kinena, murder of Emin Pasha, 96.
King, authority of, in the Congo, $117,175,176,177$; and see Albert I, Leopold II.

Kingani captured in 1915, 173.

Kinshasa, 44, 120, 223, n. 1 .

Kintamo, 44.

Kiri, 104.

Kirundu under Kibongé, 92.

Kitchener, Earl, secures the Sudan for the United Kingdom, 111.

Kivu, district of the Eastern Province, 186, 241, 244, 247.

Kivu, Lake, frontier on, altered in 1910, 162, 163.

Kongolo, 236, 237.

Koo river, 245.

Kordofan, British claim to, 113, n. 3.

Kundelungu area, diamonds in, 248. Kwango, 25, 26, 73, 156, 220.

Kwango, district of Congo-Kasai Province, 186.

Kwengo river, 245.

Kwilu river, 245.

Laboratory, governmental, at Leopoldville, 231 .

Laboré, 104.

Labour contracts, terms of, 150, 154, 181, 182, 256, 257.

Labour Party of the United Kingdon, views on Congolese administration, 130; on future of Central Africa, 279-81, 295.

Labour, question of, 254-60.

Lado, 240.

Lado enclave, 99, 112-15, 162.

Lake Albert Edward Nyanza, 75.

Lake Leopold II circumnavigated, 44.

Iake Leopold II, district of the Equator Province, 186.

Lake Nyasa, 26, 59, 303.

Lalaing, Comte de, Belgian Minister at the Court of St. James, 170, 212.

Lamont, W. J., British Consul, report on Aruwimi and Uele, 156.

Landana, 244.

Land Commission, 183.

Land concessions, rules regarding, $206,207$.

Land policy, of the State, 120-3; of the Colony, 201-8; principles affecting grants to non-nationals, 
288; as affecting native rights, 289-92.

Land registration, system of, in the Congo, 209.

Landeghem occupies Tambura, 113.

Lannoy, Charles de, work on constitutional law of the Congo, 6 ; views on domestic slavery, 214, n. 2 ; on native conditions, 233 , n. 2 ; on monopolies, 286, n. 2.

Lansdowne, Marquess of, dispatch as to Congolese administration, 131.

La Réforme, criticizes Congolese administration, 129.

La Romée, 226.

La Verité sur le Congo, 129.

Lavigerie, Cardinal, anti-slave-trade crusade, 77, 220.

League of Nations, in relation to African territories, 279-81, 297, 299.

Leave of civil servants increased by Belgian government, 152.

Legat, commandant at Lofoi, 85, 87.

Legislative power, under the State régime, 117 ; under the Colonial régime, 175, 176, 183, 185.

Lehmin, death of Von Kerckhoven at, 104.

Lemaire, explorations in 1898-1900, 88 ; occupies territory of Bio, 113.

Le Marinel, G., expedition of, 76 .

Le Marinel, P., expedition of, 83, 85.

Leo XIII approves Cardinal Lavigerie's anti-slave-trade crusade,

- 77, 220.

Leopold II, policy of, 31-41, 47, 53, 54,289 ; becomes Sovereign of the Congo, 66-70, 72, 73 ; urges Stanley to return to the Congo, 75 ; relations with Belgian government, 76, 77, 137-44 ; aims on the Nile, $101-15$; responsibility for maladministration of the State, 116, 117, 121-3, 145,146 ; policy in religious questions, 220, 221, 293 ; grants concession to $\mathrm{Mr}$. R. Williams, 240 ; gains from the Congo, 251; concession to United Kingdom of the right to construct a railway, 106-8, 277 ; aware of danger of Belgian neutrality, 295.

Leopoldville, 44, 228, 242, 251.

Le Patriote, criticizes Congolese administration, 129.

Leprince, French officer, captures Bonga, 172.

Levecque, 94 .

Lever, Messrs., oil industry enterprise in the Congo, 156, 206, 245, 255, 262, 264.

Levin, H.M.S., surveys estuary of the Congo, 25.

Liberia, 40, 49; Labour Party's proposal to place under international control, 279 ; United States' protectorate over, 298, n. 3.

Libraries in the Congo, 227.

Libreville, position of, rendered militarily untenable by treaty of 1911,166 ; submarine cable at, 242.

Lichnowsky, Prince, German Ambassador in London, negotiations as to expansion of German Colonial interests, 10, 168, n. 1, 300 .

Licona-Nkundja, 72.

Lifi, 104.

Limited sphere of operation of Berlin Act, disadvantages of, 282, 283.

Lindi river, 225.

Liotard visits Bangasso, 106.

Lippens murdered at Kasongo, 96.

Liquor traffic, control of, 77-9, 81, $82,198,215,216,292,293,317$, 318, 320-1.

Liverpool, opposition of, to annexation of the Congo by the United Kingdom in 1876, 27.

Livingstone, David, explorations of, $26,27$.

Livingstone Inland Mission, 128, 218.

Loanda, 21, 26.

Loans, of the Congo, 72, 73, 76, 77, 199; legislative sanction requisite for issue of new, 176 ; from the United Kingdom, 301, n. 1.

Lobaye valley, ceded to Germany by France in 1911, 166 ; retaken by France, 171. 
Lobito Bay, railway route via, 163 , 239, $243,263$.

Locations for natives in urban areas, 182.

Lodge, Senator, champions cause of natives in the Congo, 129 .

Lofoi, 84, 85, 87.

Logé, 59, 302.

Lomami, 29, 99, 157, 225.

Lomami, district of, 185, 186.

London Chamber of Commerce, protest against concessionary régime in the Congo, 130.

Long, Rt. Hon. W., Secretary of State for the Colonies (1915-19), views on restoration of German colonies, 283 , n. 5.

Lopes, Duarte, report on the Congo, 19, n. 1.

Lorand criticizes Congolese administration, 129.

Lothaire, execution of C. Stokes by, $125,126$.

Lottery loan of $150,000,000 \mathrm{fr}$. issued in $1889,72,73,76$.

Lowa, district of the Eastern Province, 186.

Lower Congo, district of CongoKasai Province, 186.

Lower Sanga valley, ceded to Germany by France in 1911, 166; retaken by France, 172 .

Lower Uele, district of the Eastern Province, 186.

Lualaba, 26, 29, 84, 98, 225, 237.

Luama, 98.

Luapula, 26, 84 .

Lubamba river, 47.

Ludendorff, General, views on German colonies, 9.

Lufira, 91, 237.

Lugard, Sir Frederick, G.C.M.G., tailure of plans for gradual spread of British influence in Nigeria, 69.

Lukafu, 88.

Lukuga valley, coal in the, 248.

Lukula, 244.

Lulindi, 98.

Lulonga, district of the Equator Province, 186, 244.

'Lulua, district of, 185, 186 ; free from tsetse-fly, 162.

Lulua river, 236.

Luluabourg, 99, 157.
Lupton, fruitless efforts to combat Mahdism in the Bahr el Ghazal, 103.

Lupungu appointed to succeed Gongo Lutété, 97.

Lusambo, 73, 86, 96.

Luvua, 71.

Mackie, H. G., British Consul, report on Mohammedanism in the Stanley Falls region, 226.

Mackinnon, Sir William, present at Brussels meeting of explorers and others, 33 .

Magistrates de carrière, status of, 194.

Mahagi, 237, 240, 247.

Mahdists, 103, 104, 111, 112.

Maize, 96.

Malet, Rt. Hon. Sir Edward B., British Ambassador at Berlin, represents the United Kingdom at the Berlin Conference, 32,n. 1, 57.

Malfeyt, Col., Royal Commissioner of Belgian occupation of German East Africa, 172.

Malamine, Sergeant, activity of, in the interests of France on the Congo, 42, 44, 48, 218.

Manbettus, 133 ; as ironworkers, 247.

Manchester,opposition of, to annexation of Congo by the United Kingdom in 1876, 27.

Mandoko, gold in, 248.

Manihot Glaziovii (Ceara), cultivation of, 261.

Manilla fibre, possibility of development of, 245, 262.

Manioc, 149, 243.

Manners, Mr., views on agricultural prospects in the Katanga, 162, n. 1 .

Manyanga, 24, 41; 46, 72.

Manyema, 27, 92, 100, 225.

Manyema, district of the Eastern Province, 186.

Marchand, Major, attempt to secure access to Nile, 110, 111.

Maréchal founds port of Pweto, 88.

Marigny, Marquis de, expels Portuguese from Kabinda, 22.

Marriage, celebration and effect of, 266. 
Masoin, Fritz, Histoire de l'État indépendant du Congo, 6 and passim.

Matadi, 26, 180, n. 4, 231, 239, 242, 251.

Matriculated natives, status of, 179 , 180,188 ; land rights of, 209 , 210 .

Matriculation of natives, 179, 180.

Maxwell, Capt., R.N., surveys the lower course of the Congo, 25.

Mayumbe, Ceara cultivated in, 261.

Mayumbe railway, 240, 244.

Mayumbé Railway Company, 240.

Mbanza 'Kongo, 19.

Mbe, Makoko of, grant of territory to de Brazza, 45 .

Mbomu, 105, 106.

Medical officers, grades of, 230 .

Medicine man, power of, 224 .

Mediterranean man, possible influence of, on Negro, 18.

Mefela, treaty with chiefs of, 201.

Members of Belgian Parliament ineligible for offices in the Congo, 178,189, n. 2.

Merlin, M., Governor-General of French Equatorial Africa, invokes Belgian aid, 171 ; reform concessionary régime in the French Congo, 285.

Mfutila, ruler of San Salvador (1891-6), 24, n. 1.

Mfwa, 44.

Michiels murdered at Riba-Riba, 95.

Middle class, desirability of creating a native, 264 .

Middle Congo, district of CongoKasai Province, 186.

Middle Congo, French possession isolated by Franco-German treaty of 1911,166 ; comparative prosperity of British trade in, 283.

Military force, under the old régime, 119,120 ; as reorganized, 189 , 190.

Military service, compulsory, 148, 190.

Milz stationed at Jabir, 103.

Mining concessions, require Parliamentary sanction, 206 ; principles affecting grant of, to non-nationals, 287, 288.

Mining industry, 246-9.
Mining revenue, 198.

Ministère public, see Public Prosecutor.

Minors, restriction on engagement of, in the Congolese service, 177, 178.

Missionary activity, encouragement of, $60,151,155,223,304$; necessity of impartial treatment of, 293.

Moena, English mission established at, 88.

Moero, 26, 86, 87, 239.

Mohammedanism, German and British policy towards, 13; extent of, in the Congo, 224-7.

Mohara, chief of Nyangwe, 92, 96 .

Moini-Hamis, chief of Kabambaré, 92.

Molembo, 23.

Molitor, Colonel, leads Belgian column in invasion of German Fast Africa, 172.

Mongala, 103, 123.

Monopolies, question of, under Berlin Act, 89, 90, 120-3, 150, 151, $153,154,157,158,304$; in the French Congo, 150, 151, 285, 286; to what extent justifiable, 286.

Monteil, Col., expedition to Ubangi, 106, 109.

Morel, E. D., attitude on Congo question, $16,129,167,273,282$, n. 1 ; on neutralization of Central Africa, 295.

Morocco, slave trade to supply needs of, 29; German policy in regard to, 165,166 ; free trade in, 300 .

Morison, Sir T., on Indian settlement in East Africa (Nineteenth Century, Sept. 1918, pp. 430-41), 290, n. 2.

Moto, government gold mine at, 247.

Motor roads in the Congo, 242.

Mountmorres, Lord, views on the Congo, 130 ; account of Mohammedanism in, 225.

Mozambique, 22.

M'Pozo, 216.

Msiri, ruler of the Katanga, 83-6.

Münster, Count, warns British Government of German hostility, 56.

Muggi, 104. 
Mundu, scene of Dervish defeat, 104.

Nachtigal, Dr., member of the Executive Committee of the Interenational African Association, 33.

Native armies, danger to European civilization of, 10, 11, 276, 296, 297.

Native chiefs, 118, 134, 147, 148, 153 ; reorganization of administration under, 187, 188; judicial powers of, 195.

Native land rights, 121, 134, 148-9, 153-4, 201-4, 289-92.

Native taxation, 60, 61, 123, 124 , 131, 147-55, 198.

Native tribunals, under State régime, 119 ; under Colonial régime, 195, 196.

Native sentinels, abuses of system of forced labour under, 123, 133.

Native troops, danger of use of, by European nations, 10, 11, 276, 296, 297.

Navigation Act for the Congo, 59, 306-12.

Navigation Act for the Niger, 62, 313-15.

Navigation, freedom of, on Congo and Niger, 59, 60, 62, 303, 306-15.

Navigation on Lakes Kivu, Albert Edward, and Albert, 163.

Ndambi Mbongo, de Brazza's visit to Stanley at, 42 .

Neduda, Egyptian post at, 104.

Negroes, development of economic activities of, 12, 13 .

Nepoko, 103.

Neré, post at, 115 .

Neutralization, provisions for, in the Berlin Act, 61, 305, 306 ; proposed application in 1914, 169-72, 294, 295 : Labour Party advocates for all Central Africa, 279; objections to, as a policy, 295-7.

Neutrality of Belgium, disadvantages of (cf. King Albert's speech, The Times, Nov. 25, 1918), $295,296$.

New Guinea, British attitude to German claims on, 55,56 .

New Hebrides, failure of AngloFrench condominium in, 281, n.1.
New York Herald, Stanley's expedition for, 27, 36.

Ngombi, treaty with chiefs of, 201. Niger, regulation of navigation of, by Berlin Act, $62,294,297,313-$ 15.

Nigeria, conditions in, compared with those in the Congo, 69, 185, 188,200 , n.1, 214, n.1; limitation of Christian missionary efforts in, on political grounds, 13 ; French trading rights in, 282 ; contribution to cost of war, 292.

Nile river, 58; Belgian advance to, 101-15; railway to, 240.

Nimptsch, Baron von, Vice-Governor of the Congo, 70.

Nisco, Baron, member of Belgian Committee of Enquiry, 132.

Nkabwa, Mount, 163.

Noblesse zuurdered at Riba-Riba, 95.

Noki, 25, 47, 51, 64 .

North-eastern Rhodesia, native labour from, 255.

Norway, participates with Sweden in the Berlin Conference, 59 ; in the Brussels Conference, 78, n. 3; treaty with the International Association, 63.

Notary Public, 177.

Notes, issue of bank, 200.

Noufflard, Charles, Lieutenant, Governor of Dahomey, 169.

Nouvelle Anvers, 228.

Nserera, chief of Riba-Riba, 92 ; submission of, 98 .

Ntenke, 85.

Nyangara, 104.

Nyangwe, 27, 29, 36, 85, 225.

N'Zilo Falls, 236.

N'Zimu, Belgian forces co-operate in capture of, 171.

Occupation, effective, as condition of recognition of sovereignty, 62, $69,298,315$.

Occupation of land by natives, interpretation of, 121, 202, 203.

Official language of the Congo, 173. Officials in the Congo, unsatisfactory character of certain, 152.

Ogoué river, 19, 43, 58, 302 ; economic results of exclusion of, from free-trade zone, 283. 
Olsen, Colonel, leads Belgian column against German Fast Africa, 172.

Omdurman, victory of, 111 .

Orange Free State (now merged in British dominions) adheres to Brussels Act, 1890, 78, n. 3.

Ordonnance, 117, 183.

Owen, Capt., R.N., explores estuary of the Congo, 26 . .

Paganism, unprogressive character of Congolese, 224.

Pallaballa, treaties with chiefs of, 49, n. 5, 201.

Palmerston, Viscount, opposes Portuguese claims in Africa, 23.

Palm kernels, uses of, 128, 245, 261, 262.

Palm oil, 128, 262.

Palm products, development of trade in, 245, 261, 262.

Pania Mutembé, 93, 239.

Pendjeh, friction between Russia and the United Kingdom over, 56.

Pardon, prerogative of, vested in the King, 117, 175, 184.

Parliament, Belgian, supreme control over the Congo, 175.

Pass Bureau, 182.

Pass Law, regulating movements of natives, 181, 182.

Patents, regulation of, 250.

Paul V sends mission to San. Salvador, 21.

Pay of civil service, inadequate under State, 124; increased by Belgian government, 152.

Peace Conference and Berlin Act, 301, n. 1.

Pearson, Mr., view on agricultural prospects of the Katanga, 162, n. 1.

Pedro V, of San Salvador, 24.

Pensions of civil servants, 189.

Pères blancs d'Alger, 220.

Persia, participation in the Brussels Conference, 78, n. 3.

Peschuel-Loesche, Dr., brief stay on the Congo, 44, 47, n. 2.

Pickersgill, Mr. Consul, report on the Congo, 127, 128.

Pigafetta, F., reports Duarte Lopes's account of the Congo, 19, n. 1.
Pigmies as earliest inhabitants of Congo, 18.

Piracy at Congo mouth suppressed by British vessels, 26.

Plants, introduction of new varieties of, 246.

Plymouth Brethren, 219.

Pogge travels in the Western Congo basin, 53.

Poison ordeal, use of, on the Congo, 29 ; punishment of, 195.

Police force, 194.

Police offences, power of GovernorGeneral to issue regulations as to, 184, 249.

Polygamist, legal position of wives of a, 233, n. 3,256, n. 2.

Polygamy, in the Congo, 28, 120, 213,214 ; efforts to minimize, 233, 234.

Ponthier, successful operations of, against the slave-traders, 97.

Ponthierville, 236, 237.

Ponty, W., Governor-General of French West Africa, 169.

Population, character and numbers of, 160, 259, 260.

Portugal, interests on the Congo, $19,22,28,50-4$; participates in Berlin Conference, 57,58 ; in Brussels Conference, 78, n. 3 ; boundary treaties with the Congo, 64, 73,74 ; tariff agreement, 81 ; proposed partition of colonial territories, 168, n. 1, 300 ; agreement as to arms trade, 216 ; trade with the Congo, 253 ; protective policy in Angola, 300, 301 .

Portuguese East Africa, labour from, 255 ; only partially in the free-trade zone, 283.

Portuguese mission on the Luango coast, 22.

Portuguese traders in the Congo, 253.

Postal services, 242, 304.

Poste, administrative division, now superseded, 118, 185.

Potatoes, 88.

Preferential trade with Dominions, adoption of principle of, by British Government, 299, 300.

Premiums paid by Congo Government to officials on export of produce, 164, 165. 
Prerogative of mercy vested in the King only, 117, 175, 184.

Principe, unsatisfactory labour conditions in, 15, 301.

Prison régime, 194.

Private ownership of land by natives, 210-12, 215, 264.

Procurator-General, of the Congo, 177, 184 ; presides over Commission for the protection of the natives, 232.

Property, law of, 266, 267.

Prospecting for minerals, regulations affecting, 246, 247.

Protection of the natives, 232-5.

Protestant missions, 217-19.

Protestant schools, 228, 229.

Public debt, 72, 73, 76, 77, 199, 301, n. 1.

Public domain, 205-8.

Public health, 230-2.

Public Prosecutor (Ministère public), office of, 193, 194; duties of his department, 135, 235, 258, 268, 270, 271.

Publicity of judicial proceedings, 177.

Punitive expeditions, unnecessary employment of, 150, 157.

Purdon, R. J., British Vice-Consul, report on Lomami, 156.

Pweto (Mpweto), 88, 239.

Quatrefages, M. de, member of the Executive Committee of the International African Association, 35.

Rabah invades the Bahr el Ghazal, 103.

Rabinek, case of, 89,90 .

Rachid, nephew of Tipu-Tipu, succeeds his uncle, 93 ; at first loyal to the State, 95 ; overthrow of, 97, 98.

Rafai, 103.

Railway from Matadi to Leopold. ville, 71, 236, 286.

Railway companies bound to purchase their supplies in Belgium, $286,287$.

Railway concessions, require Parliamentary sanction, 206 ; principles affecting, in the case of non-nationals, 286, 287.
Railway construction, provisions of Berlin Act as to, 240, 241.

Railways in the Congo, 236-42.

Recensement of the natives, 180, 181.

Recognition of Belgian sovereignty over Congo by the United Kingdom in 1913, 158, 290.

Recruitment of labour, regulation of, 256.

Redemptorist mission at the Cataracts, $220,221$.

Reform decrees of Leopold II, June 3, 1906, 134, 135.

Registered lands in the Congo, 209-12.

Registers of civil status, 265.

Regulation of labour conditions in mines, factories, \&c., 249, 250.

Reichardt travels in the South Congo basin, 53 .

Rejaf, 112, 240 .

Religious freedom under Berlin Act, 60, 179, 304.

Religious views of natives, British regard for, 13.

Renkin, J., Belgian Minister of the Colonies, 146, n. 2, 155, n. 2, 211, 212.

Residence of natives, regulation of, 180-2.

Residents, temporary appointment of, 118.

Rest-houses for European travellers, 242.

Revenue, sources of, 197-9.

Rhodes, Cecil, scheme for Cape to Cairo route, 106, 107, n. 1, 240.

Rhodesia, relation to the Katanga, 160,161 ; trade with, 253 ; mining labour from, 255; native land rights in Southern, 14, 290.

Rhodesia and Katanga Junction Railway and Minerals Company, 238.

Riba-Riba, 84, 92, 95, 97.

Rice, cultivation of, 88, 96, 244 .

Rights of the subject, 178, 179.

Roads. in the Congo, 242.

Roget founds post at Ibembo, 103.

Roman Catholic missionaries, work of, 19, 219-24.

Roman Catholic schools, 228, 229.

Royal Congo Company, abortive agreement with, 71 . 
Royal Geographical Society declines to take part in International African Association, 33, 34.

Rubber, 68, 91, 120, 121, 128, 153, 244,261 ; taxation on, 198, 205, 206,244 ; purity of, 254.

Rumaliza, chief of Ujiji, 92 ; final defeat of, 98 .

Russia, relation to International African Association, 33, 34 ; participates in the Berlin Conference, 59 ; in the Brussels Conference, 78, n. 3 ; treaty with the International Association, 63.

Ruwé, 90.

Ruwenzori discovered by Stanley, 75 .

Sabinio, 'Mt., 163.

Sahara as northern boundary of Central Africa, 279, 283.

Said Bargash, Sultan of Zanzibar, 93.

Said ben Abedi, chief of Kilonga, 92.

Said Kalifat, Sultan of Zanzibar, 93. .

Sakania, 159.

Sakaras, 103.

Salaries, inadequacy of official, in Congo State, 147 ; increase of, under Colonial régime, 152.

Salisbury, Marquess of, Secretary of State for Foreign Affairs, alleged approval of agreement between the King of the Belgians and the British East Africa Company in 1890,102, n. 4 ; secret treaty with Germany regarding Portuguese possessions, 168 , n. 1,300 .

Samuel, Rt. Hon. Herbert, notion as to misgovernment of the Congo, 131, 132.

Sanford, General H. S., favours formation of the Congo State, 35; secures recognition of the International Congo Association by the United States, 54 ; representative of the United States at the Berlin Conference, 57.

Sankuru, district of Congo-Kasai Province, 186.
Sankuru river, 93, 238.

San (São) Salvador, kingdom of, 19-22, 24, 50.

San (São) Thomé, unsatisfactory conditions of native labour in, $15,301$.

São Paolo de Loanda founded in $1608,20$.

Sarawak, legal position of State of, $40,49$.

Scheme for cession of part of the Belgian Congo to Germany, 1679, 275, 276.

Schnee, Dr., Governor of German East Africa, efforts to overthrow Mohammedanism in, 13.

Schollaert, Premier of Belgium, arranges for cession of Congo, 141, 142.

School of Tropical Medicine at Brussels, 183, 230.

Schools for sons of chiefs, 228, 234.

Schumacher, E. de, member of Belgian Commission of Enquiry, 132.

Scotia, arrest of Rabinek on board the, 89,90 .

Scott, John, assists Portuguese subjects in murders on the Congo, 50 .

Scott-Keltie, Dr. T., Partition of Africa, 6; view of Lord Granville's colonial policy, 52 .

Seal of the Congo, 178.

Sebastião, King of Portugal, sends aid to the King of the Congo, 20.

Secretaries of State of the Congo, $116,117$.

Secretary-General of the Congo, 184.

Secteur, administrative division, now superseded, 118, 185 .

Sefu, attitude to the State, 95, 96.

Seminary at Louvain to $\mathrm{p}$ ovide priests for the Congo, 220 .

Semio, Asandé chief, 103.

Semliki river, 75, 114.

Senegal, disadvantage to British trade of protectionist régime in, 283.

Senegalese troops, French use of, $10,297$.

Sentinels, use of native, to secure collection of rubber, 123, 133.

Separation of judicial and executive 
powers, 191 ; results in exclusion of administrative actions from control by ordinary courts, 289 .

Shari river, 58, 104, 302.

Sharpe, Sir Alfred, K.C.M.G., urges Msiri to accept British protection, 83.

Shinkakasa, fort at, 73 ; revolt at, 100.

Shipping, 242, 243.

Shiré river, 52, 302.

Shiwala, Arab chief, defeated by Brasseur, 87.

Shungufu killed in 1899, 100.

Sierra Leone, native taxation in, 131.

Simba, Arab chief, defeated by Brasseur, 87.

Sizal, cultivation of, 245 .

Sjöblom, American Baptist missionary, reports atrocities in the Congo, 128.

Slave trade, $22,23,28,29,30,52$; Berlin Act, 60, 61, 305; Brussels Act, 78 ; prevention of, in the Congo, 195.

Sleeping sickness, 231, 232 ; effect on population, 259.

Small-pox, steps to prevent, 232.

Smuts, General Rt. Hon. J. C., views on German colonial aims, 10 , n. $3,11,296$; campaign in German East Africa, 172 ; objections to international government, 281, n. 1 ; claim for German South-West Africa, 283, n. 5 , 300.

Société anonyme belge, 155, 251.

Société anversoise du commerce, $154,251$.

Sociéte Belge du Haut Congo, 121.

Société d'études coloniales, 138.

Société générale, 91.

Solf, Dr., formerly German Secretary of State for Foreign Affairs, views as to German Colonies, 9, n. 1,10, n. 3.

Solicitors not necessary in Congo, 194.

Somaliland only partially within the free-trade zone, 283.

Sonyo (San Antonio), 22, 220.

Southern Rhodesia, unsatisfactory position of native land rights in, $13,14,290$.
South-West Africa, treatment of natives by Germans in, 12, n. 1 .

Spain, participates in the Berlin Conference, 59 ; in the Brussels Conference, 78 , n. 3 ; treaty with the International Association, 63; treaty regarding arms traffic, 216 .

Spanish Guinea, right of preemption over, ceded by France to Germany in 1911, 166.

Stairs, Capt., overthrows Msiri, 85, 86.

Stanley, Sir Henry Morton, G.C.B., relieves David Livingstone, 27 ; solves question of the Congo, 36, 37 ; enters service of Leopold II, 37-41; rivalry with de Brazza, 42-5; relieves Emin Pasha, 75, 76 ; advises suppression of slavetraders, 92, n. 1 ; concludes agreement with East Africa Co., 102.

Stanley Pool, 24, 25, 41, 236.

Stanleyville, 228, 236, 242, 247.

Stanleyville, district of the Eastern Province, 186.

State Inspectors, 117, 184.

Status, law as to, 265.

Stokes, Charles, murder of, by Lothaire, 125, 126.

Strauch, Col., President of the Comité d'Etudes du Haut Congo and Secretary-General of the International African Association, 39, 40, 57, 62, 63, 66 .

Strom, Mr., representative of the Livingstone Inland Mission, 218. Submarine bases, German aim to acquire overseas, 10, 276.

Submarines, danger of, to British Empire and sea-power, 9, 10, 276.

Succession, law of, 267.

Sudan, General Gordon's mission to the, 47 ; treaties affecting the, 104 ; boundary of the Congo with the, 162,163 ; secured by Earl Kitchener, 111 ; small portion of, in the free-trade zone, 283.

Sugar-cane, cultivation of, 96 .

Suspension of civil jurisdiction, power of King to order, 177.

Sweden, participates with Norway in the Berlin Conference, 59 ; in the Brussels Conference, 78, n. 3 ; treaty with the International Association, 63. 
Swedish Missionary Society, 219.

Switzerland, relation to International African Association, 34, 35 .

Syndicat commercial du Katanga, $84,85$.

Syphilis, 232, n. 1, 234.

Tabora, capture of, by Allies, 172 ; Belgian occupation of, 277.

Tambatamba, 226.

Tambura, Liotard establishes post at, 110; occupied by Landeghem, 113.

Tanganyika, Lake, 170, 171, 220, 237, 302.

Tanganyika Concessions Limited, 90.

Tanganyika-Moero, district of, 185 , 186.

Taxation requires legislative sanction, 176.

Tele, 247.

Telegraphs in the Congo, 242.

Territorial administrators, administrative and judicial functions of, $182,186,191,192,258,264$, n. 2.

Territorial agents, position of, 186 .

Territorial Tribunals, under the State régime, 118, 119 ; under the Colony, 191, 192.

Thomson, Joseph, exploration of borders of the Congo territory, 83 .

Thys, Capt., founds Compagnie du Congo pour le Commerce et l'Industrie, $71,250$.

Thysville, 231, 239.

Tin at Bukama and Kiamoi, 248.

Tipu-Tipu as Vali at the Falls, 75 , $92,93$.

Tobback, agent of the State at Stanley Falls, 95.

Togoland, liquor traffic in, 81 ; operations affecting, in the European War, 169, 170, 296.

Tombeur, Major-Gen., K.C.M.G., victorious campaign against German East Africa, 172, 173.

Torrens system of Land Registration in the Congo, 209.

Touchard, M., views as to interpretation of Art. XVI of the Berlin Act, 241.

Trade marks, regulation of, 250 .

Trade powder, 80 .
Training of State officials, 189.

Trappists, mission of, 220 .

Treasurer-General of the Congo, 117.

'Treasury bills, authorization of issue of, 176.

Treaties, control of Belgian Parliament over, 175, n. 2.

Treaties with natives affecting land rights, 201, 202.

Treaty, or treaties, concluded by de Brazza, 42, 43, 45, n. 1, 48.

Treaty between Belgium and the Congo for the cession of the Congo, 138-42.

Treaty between Belgium and France, Feb. 5, 1895, 110 ; Dec. 23, 1908, 144.

Treaty between the Congo, the United Kingdom, France, Germany, Portugal, and Spain regarding the arms traffic, 216 , 217.

Treaty between France and the International Congo Association, A pril 23, 1884, 54; Feb. 5, 1885, $63,64,72$; between France and the Congo State, Nov. 27, 1885, 72 ; April 29, 1887, 72, 73 ; Aug. $14,1894,109$.

Treaty between France and Germany, Nov. 4, 1911, 165-7; determined by the war of 1914, 275.

Treaty between France and Portugal, May 12, 1886, 54, n. 2.

Treaty between Germany and the Congo, Nov. 8, 1884, 63, 107.

Treaty between Germany and Portugal, Dec. 30, 1886, 54, n. 2.

Treaty between Portugal and the Congo, Feb. 14, 1885, 64, 73; May 25, 1891, 74 .

Treaty between the United Kingdom and the Congo, Dec. 16, 1884, 63; May 12, 1894, 106, 107 ; June 22, 1894, 108; May 9, $1906,113,114,240$.

Treaty between the United Kingdom and France, June 14, 1898, 282 ; March 21, 1899, 111, 282.

Treaty between the United Kingdom and Germany, July 1, 1890 , 105,113, n. 3. 
Treaty between the United Kingdom and Italy, April 15, 1891, 105.

Treaty of July 15, 1840, regarding Turkish Dominions, 104, 105.

Treaty of Rio de Janeira, Feb. 19, 1810, 22.

Treaty of Vienna, Jan. 22, 1815, $22,23$.

Tsetse-fly, effect on agriculture in the Congo, 161, 162.

Tuckey, Capt. J. K., R.N., survey of the Congo in 1816, 25.

Turkey, participates in the Berlin Conference, 57 ; in the Brussels Conference, 78, n. 3 ; treaty with the International Congo Association, 65; claims in the Sudan, 104, 105 ; supports British criticism of the Congolese administration, 131.

Ubangi, 109, 115, 121, 168, 170.

Ubangi, district of the Equator Province, 186.

Ubangi and Shari-Ghad separated in 1911-12 from the Middle Congo, 166.

Uele, 105, 246, 247.

Ujiji, 27, 92, 98, 100, 172, 225, 239.

Undesirable characters, prevalence of, in Katanga, 181.

Union minière du Haut Katanga, $90,238,248$; under contract with government to purchase its supplies in Belgium, 286.

Union of South Africa, claim to German South-West Africa, 283.

United Kingdom, and Belgium,,relations as to Congo, 14; attitude towards proposed annexation of the Congo, 27, n. 1; relation to International African Association, 33, 34; indifference to Stanley's suggestions for activity on the Congo, 37, 38 ; relations with Portugal as to the Congo, $23,24,50-4$; participation in the Berlin Conference, 57, 58, 64 ; in the Brussels Conference, 77,78 ; treaty with the International Congo Association, 63, 64 ; waives right to exercise consular jurisdiction, 67,68 ; treaty as to southern boundary, 87 ; refusal to allow Gordon to proceed south, 101,102 ; treaty with the Congo State, May 12, 1894, 104-8; treaty of June 22, 1894, 108-14; dispute with the Congo in the Stokes case, 125,126 ; criticizes maladministration of the Congo, 129-36 ; case against the Congo and Belgium reforms, 145-58; retrocession of Lado enclave, 162 ; boundary with Congo, 162, 163 ; negotiations with Germany, 168 , n. 1 ; co-operation with Belgium in campaign in East Africa, 16974 ; trade interests in Central Africa, 282, 285 ; interest in Cape to Cairo railway, 277, 278; loan to Congo government, $301, \mathbf{n} .1$.

United States of America, interest in International African Association, 34,35 ; view of legal position of the Association, 49; recognizes itas a sovereign power, 53; represented at, but does not ratify Act of, the Berlin Conference, $57,58,298$; represented at the Brussels Conference, 78, n. 3 ; ratifies Brussels Act, 298 ; criticizes Congolese government, 129 , 143 ; necessity of participation in any amendment of the Berlin Act, 298.

Universal Postal Union, Congolese membership of, 242,304 .

Upper Luapula, district of, 185, 186. Upper Uele, district of the Eastern Province, 186.

Urban VIII erects the Congo Kingdom into an Apostolic Prefecture, 21.

Uvira, 242.

Vaccination, popularity of, 232, n. 1.

Vandervelde, Belgian Socialist leader, $130,134,155,156,157$, $222,281$.

Van de Velde, Lieut., founds stations on the Kwilu, 46.

Van Eetvelde, Baron, concludes on behalf of Congo agreement with United Kingdom of 1894, 106.

Van Gèle, expeditions of, 76, 103. 
Van Kerckhoven, expeditions of, 76 , 103, 104.

Van Neuss, Administrator-General of the Interior, 116.

Verdick, Commandant of Lofoi, 87.

Vermeersch, Father, criticizes Congolese administration, 129.

Vice-Governor-General, under State régime, 117; under Colonial régime, 160, 177, 184, 185.

Victoria Falls, 26.

Vilvorde, school of agriculture and horticulture at, 227.

Virements, provision for authorization of, 176.

Vivi, 40, 44, 46.

Wadelai, 104, 112.

Wahis, Baron, Governor-General, views on use of sentries to secure collection of produce, 127, 147.

Warfare, methods of, introduced by the Portuguese, 25.

Wason, Rt. Hon. J. Cathcart, referred to, $282, \mathrm{n} .1$.

Wauters, A. J., disapproves trade policy of the Congo State, 122.

Weights and measures, standards of, 254 .

Wells, H. G., pamphlet on terms of peace with Germany, 280.

West Africa, proposals for development of palm industry in, 290, 291.

West African shipping trade, German share of, 243.

Westcott Independent Mission, 219.

Westlake, Professor J., views on State trading in the Congo, 122.

Wheat, cultivation of, 88,254 .

White settlement in the Congo, Belgian efforts to encourage, 160 , $161,245$.

Williams, $R_{\text {, }}$ commercial relations with Leopold II, 90, 91, 237, 238, 240 ; quoted, 248, n. 1, 273, n. 1.

Wingate, Sir F., Sirdar, interview with Hanolet, 113.

Wintgens, Major, capture of, by Belgians, 174.
Winton, Col. Sir Francis de, succeeds Stanley on the Congo, 48 , 72 ; superseded by M. Camille Janssen, 70.

Wireless telegraphy in the Congo, 242.

Wissmann, Major, forms post at Luluabourg, 73.

Witchcraft on the Congo, 29, 224.

Woermann steamship line, 242.

Woeste, Catholic leader in Belgian Parliament, attitude of, to the Congo, 138, 139.

Women, depression of position of, by polygamy, 213 ; overw ork of, under State régime, 149.

Workshops, regulations for inspection of, 250.

Yakomas, submit to Van Gèle, 103. Yalala Falls visited by Sir R. Burton, 26.

Yambata, 150.

Yango, 84.

Yaunde, Belgian's share in occupation of, 171 .

Yei, 113 .

Zaire, Portuguese name of the Congo, 21.

Zambe, military school at, 120.

Zambezi, 26, 59, 225, 302 ; freedom of navigation on, 51 ; as boundary of Central Africa, 283.

Zanzibar, participates in Brussels Conference, 78, n. 3 ; accepts Berlin Act, 65, n. 1.

Zapo-Zap, chief of Luluabourg, misdeeds of, 157 .

Zboinski, Capt., decides line of railway to Stanley Pool, 71.

Zimmermann, Herr, proposal for neutralization of Congo area, 171 .

Zinga, occupation of, in 1914 by French forces, 171.

Zone, subdivision of district, now superseded, 118, 185.

Zulus, effort to recruit for Congo army, 120. 
Dizenny.

Orlikell.

Demmani

xoud. 


\section{DAY USE}

RETURN TO DESK FROM WHICH DAnnowmm

\section{DAY USE}

RETURN TO DESK FROM WHICH BORROWED

\section{LOAN DEPT.}

RENEWALS ONLY-TEL. NO. 642-3405

This book is due on the last date stamped below, or

on the date to which renewed.

E

REC'D LD SEP 15 $71-6$ PM 00

Renewed books are subject to immediate recall.

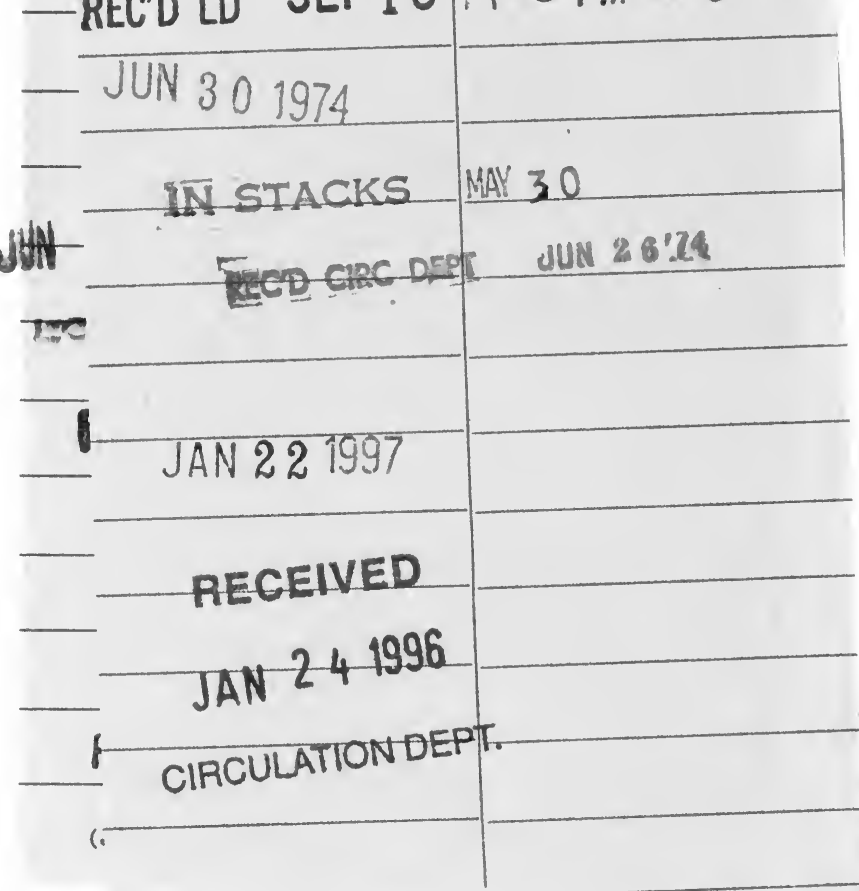

LD21A-60m-3,'70

(N5382s10) 476-A-32

General Library

University of California

Berkeley 


\section{$\bar{Y} \mathrm{Y} 47943$}

U. C. BERKELEY LIBRARIES

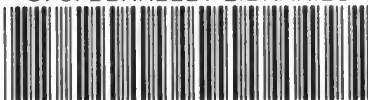

c056105128

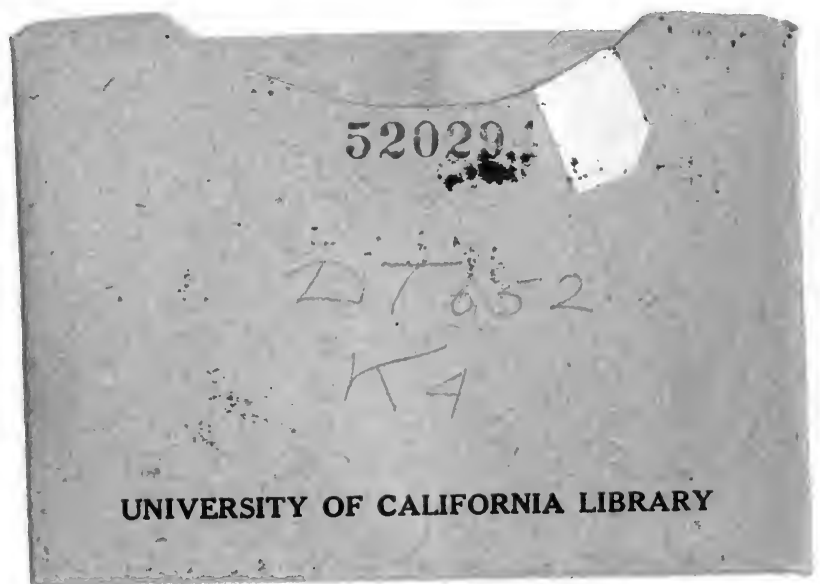




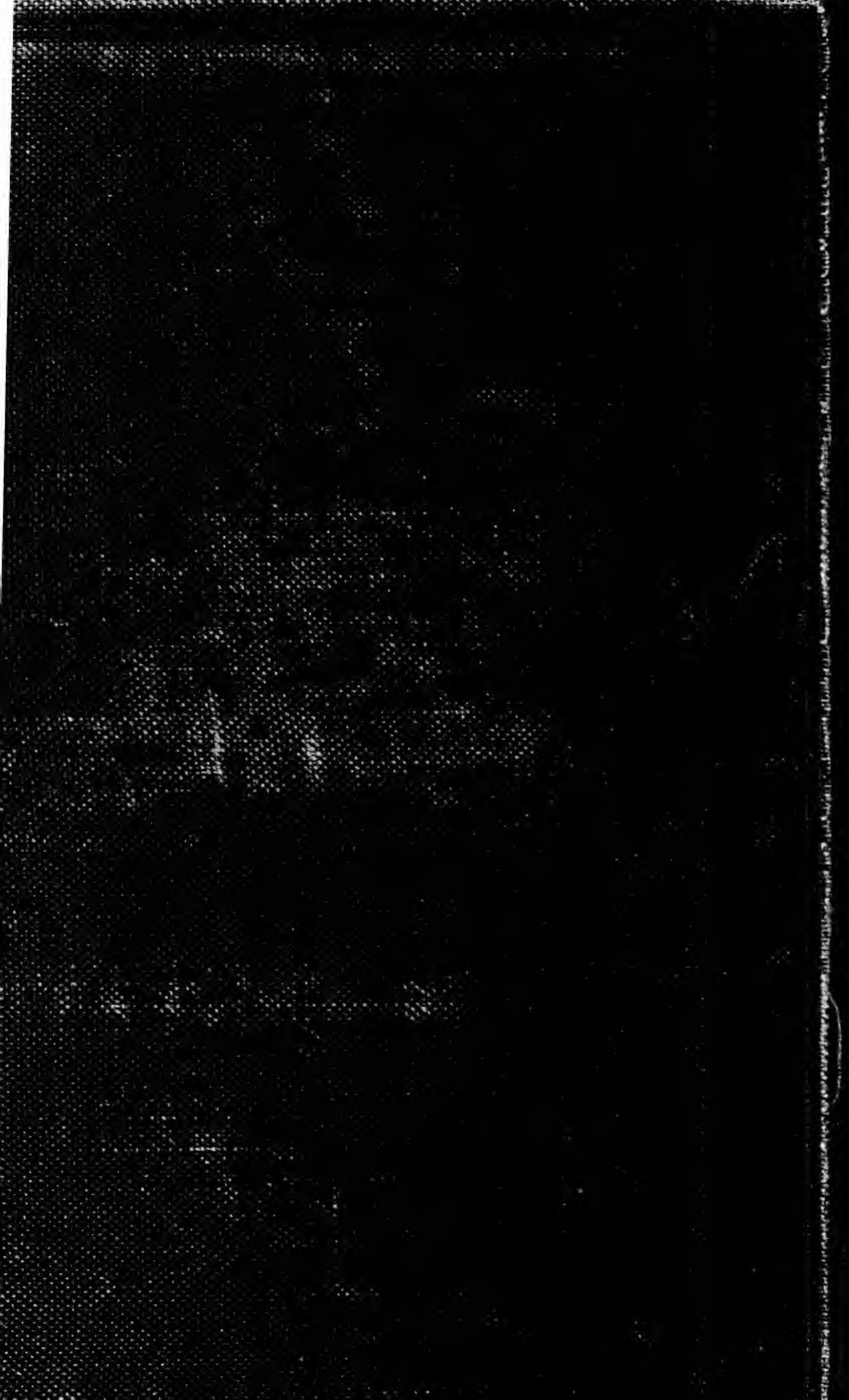

